Volume $5 \square$ Number $12 \square$ December 2008

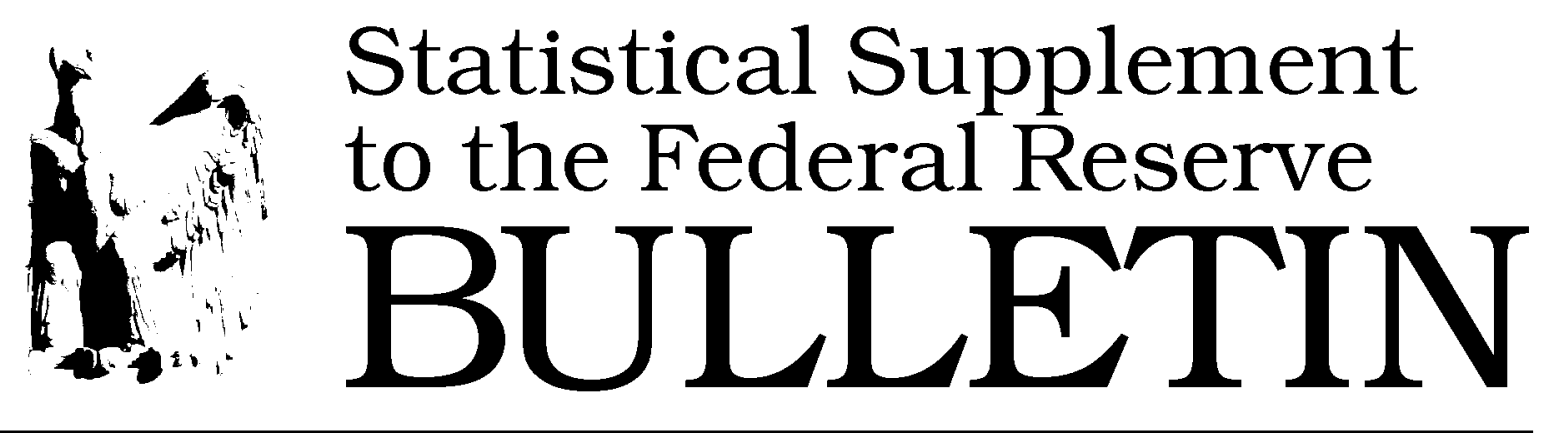

Board of Governors of the Federal Reserve System, Washington, D.C. 


\section{Publications CommitTeE}

Rosanna Pianalto Cameron, Chair $\square$ Scott G. Alvarez $\square$ Sandra Braunstein $\square$ Roger T. Cole $\square$ Marianne M. Emerson $\square$ Jennifer J. Johnson $\square$ Karen H. Johnson $\square$ Brian F. Madigan

$\square$ Stephen R. Malphrus $\square$ Louise L. Roseman $\square$ David J. Stockton 


\section{IMPORTANT NOTICE TO SUBSCRIBERS \\ of the \\ Statistical Supplement \\ to the Federal Reserve Bulletin}

Effective with the publication of this issue of the Statistical Supplement to the Federal Reserve Bulletin, the Board is discontinuing both the print and online versions.

The majority of data published in the Statistical Supplement are available elsewhere on the Federal Reserve Board's website at www.federalreserve.gov. The Board has created a webpage that provides a detailed list of links to the most recent data on its site and links to other data provided by the Federal Reserve Bank of New York, the U.S. Treasury, and the Federal Financial Institutions Examination Council. The Board will continue to publish the following tables from the Statistical Supplement in the Statistics and Historical Data section of its website:

1.36 Stock Market, Selected Statistics

1.45 New Security Issues, State and Local Governments

1.46 New Security Issues, U.S. Corporations

1.54 Mortgage Debt Outstanding

3.10 U.S. International Transactions, Summary

3.12 U.S. Reserve Assets

3.13 Foreign Official Assets Held at Federal Reserve Banks

3.15 Selected U.S. Liabilities to Foreign Official Institutions

3.16 Liabilities to, and Claims on, Foreigners

3.17 Liabilities to Foreigners

3.18 Banks' Own Claims on Foreigners

3.19 Banks' Own and Domestic Customers' Claims on Foreigners

3.22 Liabilities to Unaffiliated Foreigners

3.23 Claims on Unaffiliated Foreigners

3.24 Foreign Transactions in Securities

3.25 Marketable U.S. Treasury Bonds and Notes, Foreign Transactions

4.20 Assets and Liabilities of Commercial Banks

4.30 Assets and Liabilities of U.S. Branches and Agencies of Foreign Banks

Data for the Board's principal statistical releases are available free in multiple formats at www.federalreserve.gov/releases.

The Statistical Supplement to the Federal Reserve Bulletin (ISSN 1547-6863) is published by the Board of Governors of the Federal Reserve System, Washington, DC 20551.

POSTMASTER: Send address changes to Statistical Supplement to the Federal Reserve Bulletin, PUBLICATIONS FULFILLMENT, Mail Stop 127, Board of Governors of the Federal Reserve System, Washington, DC 20551. 


\section{Preface}

The Statistical Supplement to the Federal Reserve Bulletin, which began publication in 2004, is a continuation of the Financial and Business Statistics section that appeared in each month's issue of the Federal Reserve Bulletin (1914-2003). All statistical series in the Statistical Supplement have been published with the same frequency that they had in the Bulletin, and the numbering system for the tables have remained the same.
Please note that the Statistical Supplement will cease publication in both the print and online versions with this issue. For more information, see "Important Notice to Subscribers" on the inside front cover. 


\section{Financial and Business Statistics: Table of Contents}

These tables reflect the data available as of the second week of December 2008.

\section{SYMBOLS AND ABBREVIATIONS}

DOMESTIC FINANCIAL STATISTICS

\section{Money Stock and Bank Credit}

4 Reserves and money stock measures

5 Factors affecting reserve balances of depository institutions

6 Reserves and borrowings-Depository institutions

\section{Policy Instruments}

7 Federal Reserve Bank interest rates

8 Reserve requirements of depository institutions

9 Federal Reserve open market transactions

\section{Federal Reserve Banks}

10 Condition and Federal Reserve note statements

11 Maturity distribution of loans and securities

\section{Monetary and Credit Aggregates}

12 Aggregate reserves of depository institutions and monetary base

13 Money stock measures

\section{Commercial Banking Institutions-} Assets and Liabilities

15 All commercial banks in the United States

16 Domestically chartered commercial banks

17 Large domestically chartered commercial banks

19 Small domestically chartered commercial banks

20 Foreign-related institutions

21 Memo items

\section{Financial Markets}

22 Commercial paper outstanding

22 Prime rate charged by banks on short-term business loans

23 Interest rates-Money and capital markets

24 Stock market-Selected statistics

\section{Federal Finance}

25 Federal debt subject to statutory limitation

25 Gross public debt of U.S. TreasuryTypes and ownership

26 U.S. government securities dealers-Transactions

27 U.S. government securities dealersPositions and financing

28 Federal and federally sponsored credit agencies-Debt outstanding

\section{Securities Markets and Corporate Finance}

29 New security issues-State and local governments

29 New security issues-U.S. corporations

30 Open-end investment companies - Net sales and assets

30 Domestic finance companies-Assets and liabilities

31 Domestic finance companies-Owned and managed receivables

\section{Real Estate}

32 Mortgage markets-New homes

33 Mortgage debt outstanding

\section{Consumer Credit}

34 Total outstanding

34 Terms

\section{Flow of Funds}

35 Funds raised in U.S. credit markets

37 Summary of financial transactions

38 Summary of credit market debt outstanding

39 Summary of financial assets and liabilities

\section{DOMESTIC NONFINANCIAL STATISTICS}

\section{Selected Measures}

40 Output, capacity, and capacity utilization

42 Industrial production-Indexes and gross value 


\section{INTERNATIONAL STATISTICS}

\section{Summary Statistics}

44 U.S. international transactions

44 U.S. reserve assets

45 Foreign official assets held at Federal Reserve Banks

45 Selected U.S. liabilities to foreign official institutions

Reported by Banks in the United States

45 Liabilities to, and claims on, foreigners

46 Liabilities to foreigners

48 Banks' own claims on foreigners

49 Banks' own and domestic customers' claims on foreigners

Reported by Nonbanking Business Enterprises in the United States

50 Liabilities to unaffiliated foreigners

52 Claims on unaffiliated foreigners

Securities Holdings and Transactions

54 Foreign transactions in securities

55 Marketable U.S. Treasury bonds and notes-Foreign transactions
Interest and Exchange Rates

56 Foreign exchange rates and indexes of the foreign exchange value of the U.S. dollar

57 GUIDE TO SPECIAL TABLES

SPECIAL TABLES

58 Assets and liabilities of commercial banks, September 30, 2008

60 INDEX TO STATISTICAL TABLES

62 FEDERAL RESERVE BOARD PUBLICATIONS

64 ANTICIPATED SCHEDULE OF RELEASE DATES FOR PERIODIC STATISTICAL RELEASES

66 PUBLICATIONS OF INTEREST

67 FEDERAL RESERVE STATISTICAL RELEASES AVAILABLE ON THE COMMERCE DEPARTMENT'S ECONOMIC BULLETIN BOARD 


\section{Symbols and Abbreviations}

\begin{tabular}{|c|c|}
\hline $\mathrm{c}$ & Corrected \\
\hline e & Estimated \\
\hline n.a. & Not available \\
\hline n.e.c. & Not elsewhere classified \\
\hline $\mathrm{p}$ & Preliminary \\
\hline $\mathrm{r}$ & $\begin{array}{l}\text { Revised (Notation appears in column heading } \\
\text { when about half the figures in the column have } \\
\text { been revised from the most recently published } \\
\text { table.) }\end{array}$ \\
\hline * & $\begin{array}{l}\text { Amount insignificant in terms of the last decimal } \\
\text { place shown in the table (for example, less than } \\
500,000 \text { when the smallest unit given is in millions) }\end{array}$ \\
\hline 0 & Calculated to be zero \\
\hline & Cell not applicable \\
\hline ABS & Asset-backed security \\
\hline ATS & Automatic transfer service \\
\hline BIF & Bank insurance fund \\
\hline CD & Certificate of deposit \\
\hline $\mathrm{CMO}$ & Collateralized mortgage obligation \\
\hline CRA & Community Reinvestment Act of 1977 \\
\hline FAMC & Federal Agricultural Mortgage Corporation \\
\hline FFB & Federal Financing Bank \\
\hline FFIEC & Federal Financial Institutions Examination Council \\
\hline FHA & Federal Housing Administration \\
\hline FHLBB & Federal Home Loan Bank Board \\
\hline FHLMC & Federal Home Loan Mortgage Corporation \\
\hline FmHA & Farmers Home Administration \\
\hline FNMA & Federal National Mortgage Association \\
\hline FSA & Farm Service Agency \\
\hline FSLIC & Federal Savings and Loan Insurance Corporation \\
\hline G-7 & Group of Seven \\
\hline G-10 & Group of Ten \\
\hline GDP & dome \\
\hline
\end{tabular}

\section{GENERAL INFORMATION}

In many of the tables, components do not sum to totals because of rounding.

Minus signs are used to indicate (1) a decrease, (2) a negative figure, or (3) an outflow.

"U.S. government securities" may include guaranteed issues

\begin{tabular}{|c|c|}
\hline GNMA & Government National Mortgage Association \\
\hline GSE & Government-sponsored enterprise \\
\hline HUD & $\begin{array}{l}\text { Department of Housing and Urban } \\
\text { Development }\end{array}$ \\
\hline IBF & International banking facility \\
\hline IMF & International Monetary Fund \\
\hline IOs & Interest-only, stripped, mortgage-backed securities \\
\hline IPCs & Individuals, partnerships, and corporations \\
\hline IRA & Individual retirement account \\
\hline MMDA & Money market deposit account \\
\hline MSA & Metropolitan statistical area \\
\hline NAICS & North American Industry Classification System \\
\hline NOW & Negotiable order of withdrawal \\
\hline OCDs & Other checkable deposits \\
\hline OPEC & Organization of Petroleum Exporting Countries \\
\hline OTS & Office of Thrift Supervision \\
\hline PMI & Private mortgage insurance \\
\hline POs & Principal-only, stripped, mortgage-backed securities \\
\hline REIT & Real estate investment trust \\
\hline REMICs & Real estate mortgage investment conduits \\
\hline RHS & Rural Housing Service \\
\hline RP & Repurchase agreement \\
\hline RTC & Resolution Trust Corporation \\
\hline $\mathrm{SCO}$ & Securitized credit obligation \\
\hline SDR & Special drawing right \\
\hline SIC & Standard Industrial Classification \\
\hline STRIPS & $\begin{array}{l}\text { Separate trading of registered interest and principal } \\
\text { of securities }\end{array}$ \\
\hline TIIS & See TIPS \\
\hline TIPS & $\begin{array}{l}\text { Treasury inflation-protected securities (formerly } \\
\text { TIIS, or Treasury inflation-indexed securities) }\end{array}$ \\
\hline VA & Department of Veterans Affairs \\
\hline
\end{tabular}

of U.S. government agencies (the flow of funds figures also include not fully guaranteed issues) as well as direct obligations of the U.S. Treasury.

"State and local government" also includes municipalities, special districts, and other political subdivisions. 


\section{Federal Reserve Bulletin Statistical Supplement $\square$ December 2008}

\subsection{RESERVES AND MONEY STOCK MEASURES}

Percent annual rate of change, seasonally adjusted'

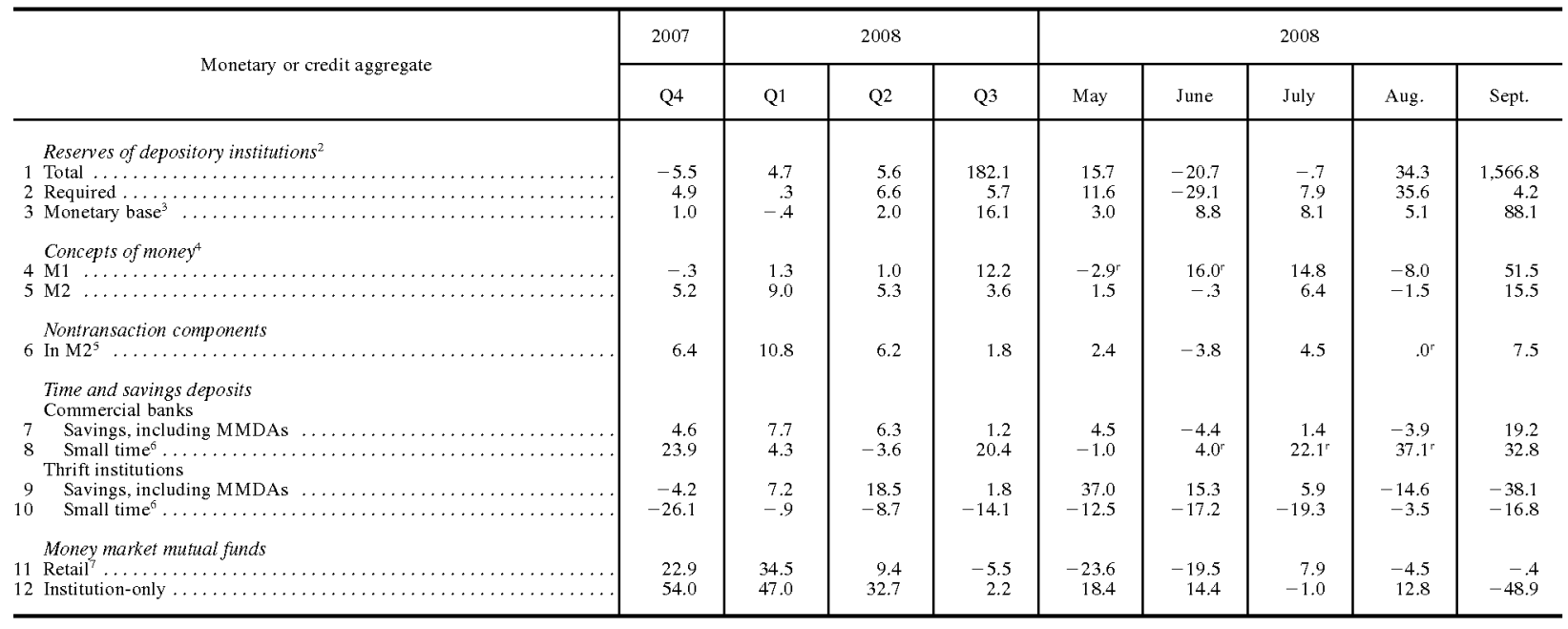

1. Unless otherwise noted, rates of change are calculated from average amounts outstanding during the preceding month or quarter.

2. Figures incorporate adjustments for discontinuities, or "breaks," associated with regulatory changes in reserve requirements. (See also table 1.20 .)

3. The seasonally adjusted, break-adjusted monetary base consists of (1) seasonally adjusted, break-adjusted total reserves (line 1 ), plus (2) the seasonally adjusted currency component of the money stock, plus (3) (for all quarterly reporters on the "Report of Transaction Accounts, Other Deposits and Vault Cash" and for all weekly reporters whose vault cash exceeds their required reserves) the seasonally adjusted, break-adjusted difference between current vault cash and the amount anplied to satisfy current reserve requirements.

4. Composition of the money stock measures is as follows:

M1 consists of (1) currency outside the U.S. Treasury, Federal Reserve Banks, and the vaults of depository institutions: (2) travelers checks of nonbank issuers: (3) demand deposits at commercial banks (excluding those amounts held by depository institutions, the U.S. government, and foreign banks and official institutions) less cash items in the process of collection and Federal Reserve flost, and (4) other checkable deposits (OCDs) consisting of cor withdrawal (NOW) and automatic transfer service (ATS) accounts depository institutions, credit union share draft accounts, and demand deposits at thrif institutions. Seasonally adjusted M1 is constructed by summing currency, travelers checks, demand deposits, and OCDs, each seasonally adjusted separately.

M2 consists of M1 plus (1) savings deposits (including money market deposit accounts) (2) small-denomination time deposits (time deposits in amounts of less than $\$ 100,000$ ), less individual retirement accounts (IRA) and Keogh balances at depository institutions; and (3) balances in retail money market mutual funds, less IRA and Keogh bal ances at money market mutual funds Seasonally adjusted M2 is constructed by summing savings deposits, smalldenomination time deposits, and retail money fund balances, each seasonally adjusted separately, and adding this result to seasonally adjusted M1.

5. Sum of (1) savings deposits (including MMDAs), (2) small time deposits, and (3) retail money fund balances, each seasonally adjusted separately.

6. Small time deposits are those issued in amounts of less than $\$ 100,000$. All IRA and Keogh account balances at commercial banks and thrift institutions are subtracted from small time deposits.

7. IRA and Keogh account balances at money market mutual funds are subtracted from retail money funds. 


\begin{tabular}{|c|c|c|c|c|c|c|c|c|c|}
\hline & & Ave & e of daily & ures & & Averag & f daily figu & for week & ing on dat \\
\hline & Factor & & 2008 & & & & & 2008 & \\
\hline & & July & Aug. & Sept. & Aug. 13 & Aug. 20 & Aug. 27 & Sept. 3 & Sept. 10 \\
\hline & SUPPLYING RESERVE FUNDS & & & & & & & & \\
\hline 1 & Reserve Bank credit outstanding & 889,322 & 888,878 & $1,054,506$ & 886,205 & 889,872 & 886,484 & 894,412 & 890,442 \\
\hline 2 & Securities held outright ....... & 479,042 & 479,486 & 481,559 & 479,396 & 479,500 & 479,604 & 479,701 & 479,762 \\
\hline 3 & U.S. Treasury ${ }^{2} \ldots$. & 479,042 & 479,486 & 478,392 & 479,396 & 479,500 & 479,604 & 479,701 & 479,762 \\
\hline 4 & Bills ${ }^{3} \ldots \ldots$ & 21,740 & 21,740 & 20,303 & 21,740 & 21,740 & 21,740 & 21,740 & 21,740 \\
\hline 5 & Notes and bonds, nominal ${ }^{3}$ & 412,371 & 411,731 & 411,731 & 411,731 & 411,731 & 411,731 & 411,731 & 411,731 \\
\hline 6 & Notes and bonds, inflation-indexed ${ }^{3}$ & 39,192 & 39,832 & 39,832 & 39,832 & 39,832 & 39,832 & 39,832 & 39,832 \\
\hline 7 & Inflation compensation ${ }^{4} \ldots \ldots \ldots \ldots$ & 5,739 & 6,183 & 6,527 & 6,093 & 6,197 & 6,301 & 6,398 & 6,459 \\
\hline 8 & Federal agency ${ }^{3} \ldots \ldots \ldots$ & 0 & 0 & 3,167 & 0 & 0 & 0 & 0 & 0 \\
\hline 9 & Repurchase agreements ${ }^{3}$ & 111,298 & 107,815 & 108,967 & 105,786 & 107,714 & 103,393 & 115,893 & 110,821 \\
\hline 10 & Term auction credit .... & 150,000 & 150,000 & 149,833 & 150,000 & 150,000 & 150,000 & 150,000 & 150,000 \\
\hline 11 & Other loans ........ & 15,423 & 18,021 & 133,726 & 17,807 & 17,609 & 18,570 & 19,070 & 19,891 \\
\hline 12 & Primary credit & 15,068 & 17,923 & 29,471 & 17,699 & 17,513 & 18,469 & 18,976 & 19,796 \\
\hline 13 & Secondary credit & 103 & 2 & 73 & 7 & 0 & 0 & 0 & 0 \\
\hline 14 & Seasonal credit. & 99 & 97 & 92 & 100 & 95 & 100 & 93 & 95 \\
\hline 15 & Primary dealer and other broker-dealer credit ${ }^{6}$ & 153 & 0 & 54,873 & 0 & 0 & 0 & 0 & 0 \\
\hline 16 & Asset-backed commercial paper money & & & & & & & & \\
\hline & market mutual fund liquidity facility & 0 & 0 & $28,498^{r}$ & 0 & 0 & 0 & 0 & 0 \\
\hline 17 & Other credit extensions..$\ldots \ldots \ldots \ldots$. & 0 & 0 & 20,719 & 0 & 0 & 0 & 0 & 0 \\
\hline 18 & Net portfolio holdings of Maiden Lane LLC ${ }^{7}$ & 29,018 & 29,175 & 29,340 & 29,145 & 29,183 & 29,213 & 29,253 & 29,293 \\
\hline 19 & Float $\ldots \ldots \ldots \ldots \ldots \ldots \ldots \ldots \ldots$ & $-1,429$ & $-1,203$ & $-1,052$ & $-1,127$ & -940 & $-1,213$ & $-1,483$ & $-1,057$ \\
\hline 20 & Other Federal Reserve assets & 105,970 & 105,584 & 152,132 & 105,199 & 106,806 & 106,918 & 101,979 & 101,731 \\
\hline 21 & Gold stock ............ & 11,041 & 11,041 & 11,041 & 11,041 & 11,041 & 11,041 & 11,041 & 11,041 \\
\hline 22 & Special drawing rights certificate account & 2,200 & 2,200 & 2,200 & 2,200 & 2,200 & 2,200 & 2,200 & 2,200 \\
\hline 23 & Treasury currency outstanding ........... & 38,676 & 38,676 & 38,675 & 38,676 & 38,676 & 38,676 & 38,675 & 38,675 \\
\hline & ABSORBING RESERVE FundS & & & & & & & & \\
\hline 24 & Currency in circulation & 830,814 & 831,017 & 834,152 & 831,085 & 830,017 & 829,456 & 835,191 & 834,477 \\
\hline 25 & Reverse repurchase agreements $^{8}$ & 42,782 & 43,294 & 56,247 & 42,458 & 44,455 & 42,858 & 42,880 & 42,690 \\
\hline 26 & Foreign official and international accounts & 42,782 & 43,294 & 52,080 & 42,458 & 44,455 & 42,858 & 42,880 & 42,690 \\
\hline 27 & Dealers..$\ldots \ldots \ldots \ldots \ldots \ldots \ldots$ & & & 4,167 & 0 & 0 & 0 & 0 & 0 \\
\hline 28 & Treasury cash holdings & 287 & 300 & 270 & 298 & 297 & 302 & 281 & 275 \\
\hline 29 & Deposits with Federal Reserve Banks, other than & & & & & & & & \\
\hline & reserve balances ............ & 12,674 & 12,382 & 98,695 & 12,510 & 12,365 & 12,435 & 12,239 & 12,250 \\
\hline 30 & U.S. Treasury, general account & 5,070 & 4,806 & 5,757 & 4,859 & 4,765 & 4,828 & 4,746 & 4,723 \\
\hline 31 & U.S. Treasury, supplementary financing account & 0 & 0 & 77,914 & 0 & 0 & 0 & 0 & 0 \\
\hline 32 & Foreign official.$\ldots \ldots \ldots \ldots \ldots \ldots \ldots$ & 103 & 154 & 141 & 319 & 103 & 101 & 100 & 161 \\
\hline 33 & Service-related & 7,206 & 7,095 & 7,331 & 7,006 & 7,179 & 7,175 & 7,086 & 7,085 \\
\hline 34 & Required clearing balances & 7,206 & 7,095 & 7,331 & 7,006 & 7,176 & 7,175 & 7,086 & 7,085 \\
\hline 35 & Adjustments to compensate for float ... & 0 & 1 & & 0 & 3 & 0 & 0 & 0 \\
\hline 36 & Other $\ldots \ldots \ldots \ldots \ldots \ldots \ldots \ldots$ & 295 & 328 & 7,552 & 325 & 318 & 332 & 307 & 281 \\
\hline 37 & Other liabilities and capital 9 & 44,470 & 44,233 & 45,674 & 43,788 & 43,991 & 44,604 & 44,866 & 44,680 \\
\hline 38 & Reserve balances with Federal Reserve Banks ${ }^{10}$ & 10,212 & 9,568 & 71,384 & 7,983 & 10,664 & 8,746 & 10,871 & 7,986 \\
\hline & & & f-month $\mathrm{f}$ & & & & & Inesday fig & \\
\hline & & July & Aug. & Sept. & Aug. 13 & Aug. 20 & Aug. 27 & Sept. 3 & Sept. 10 \\
\hline & SUPPLYING RESERVE FundS & & & & & & & & \\
\hline 1 & Reserve Bank credit outstanding & 898,515 & 895,974 & $1,492,635$ & 898,870 & 882,696 & 894,222 & 888,012 & 909,783 \\
\hline 2 & Securities held outright ..... & 479,240 & 479,702 & 491,127 & 479,434 & 479,538 & 479,642 & 479,726 & 479,782 \\
\hline 3 & U.S. Treasury ${ }^{2} \ldots .$. & 479,240 & 479,702 & 476,627 & 479,434 & 479,538 & 479,642 & 479,726 & 479,782 \\
\hline 4 & Bills ${ }^{3} \ldots \ldots$ & 21,740 & 21,740 & 18,423 & 21,740 & 21,740 & 21,740 & 21,740 & 21,740 \\
\hline 5 & Notes and bonds, nominal ${ }^{3}$ & 411,731 & 411,731 & 411,731 & 411,731 & 411,731 & 411,731 & 411,731 & 411,731 \\
\hline 6 & Notes and bonds, inflation-indexed ${ }^{3}$ & 39,832 & 39,832 & 39,832 & 39,832 & 39,832 & 39,832 & 39,832 & 39,832 \\
\hline 7 & Inflation compensation ${ }^{4} \ldots \ldots \ldots$ & 5,937 & 6,399 & 6,641 & 6,131 & 6,235 & 6,339 & 6,423 & 6,480 \\
\hline 8 & Federal agency ${ }^{3} \ldots$ & 0 & 0 & 14,500 & 0 & 0 & 0 & 0 & 0 \\
\hline 9 & Repurchase agreements ${ }^{5}$ & 119,000 & 117,500 & 83,000 & 118,250 & 100,750 & 111,000 & 109,000 & 126,750 \\
\hline 10 & Term auction credit .. & 150,000 & 150,000 & 149,000 & 150,000 & 150,000 & 150,000 & 150,000 & 150,000 \\
\hline 11 & Other loans ...... & 17,529 & 19,104 & 411,870 & 17,651 & 18,563 & 19,002 & 19,089 & 23,556 \\
\hline 12 & Primary credit & 17,432 & 19,011 & 50,960 & 17,552 & 18,469 & 18,901 & 19,000 & 23,455 \\
\hline 13 & Secondary credit & 0 & 0 & 0 & 0 & 0 & 0 & 0 & 0 \\
\hline 14 & Seasonal credit . & 97 & 93 & 60 & 99 & 94 & 102 & 90 & 101 \\
\hline 15 & Primary dealer and other broker-dealer credit ${ }^{6}$ & 0 & 0 & 148,701 & 0 & 0 & 0 & 0 & 0 \\
\hline 16 & Asset-backed commercial paper money & & & & & & & & \\
\hline & market mutual fund liquidity facility & 0 & 0 & $151,070^{r}$ & 0 & 0 & 0 & 0 & 0 \\
\hline 17 & Other credit extensions & 0 & 0 & 61,080 & 0 & 0 & 0 & 0 & 0 \\
\hline & Net portfolio holdings of Maiden Lane LLC ${ }^{7}$. & 29,099 & 29,247 & 29,407 & 29,179 & 29,207 & 29,247 & 29,287 & 29,327 \\
\hline 19 & . $\ldots \ldots \ldots \ldots \ldots \ldots$ & $-2,178$ & $-1,470$ & -954 & -998 & $-1,702$ & $-1,689$ & -372 & $-1,302$ \\
\hline 20 & Other Federal Reserve assets . & 105,825 & 101,891 & 329,184 & 105,355 & 106,340 & 107,019 & 101,282 & 101,669 \\
\hline 21 & Gold stock & 11,041 & 11,041 & 11,041 & 11,041 & 11,041 & 11,041 & 11,041 & 11,041 \\
\hline 22 & Special drawing rights certificate account. & 2,200 & 2,200 & 2,200 & 2,200 & 2,200 & 2,200 & 2,200 & 2,200 \\
\hline 23 & Treasury currency outstanding ............... & 38,676 & 38,675 & 38,675 & 38,676 & 38,676 & 38,676 & 38,675 & 38,675 \\
\hline & ABsorbing Reserve Funds & & & & & & & & \\
\hline 24 & Currency in circulation & & 835,129 & 838,253 & 832,107 & 830,675 & 832.677 & 836,709 & 834,569 \\
\hline 25 & Reverse repurchas & 45,422 & 42,610 & 77,937 & 44,172 & 43,606 & 43,768 & 41,756 & 44,296 \\
\hline 26 & Foreign official and international accounts & 45,422 & 42,610 & 77,937 & 44,172 & 43,606 & 43,768 & 41,756 & 44,296 \\
\hline 27 & Dealers . & 0 & 0 & 0 & 0 & 0 & 0 & 0 & 0 \\
\hline 28 & Treasury cash holdings & 318 & 281 & 270 & 296 & 306 & 281 & 276 & 268 \\
\hline 29 & Deposits with Federal Reserve Banks, other than & & & & & & & & \\
\hline & reserve balances ....... & 12,702 & 12,164 & 366,443 & 12,142 & 12,767 & 12,648 & 13,109 & 13,312 \\
\hline 30 & U.S. Treasu & 5,256 & 4,681 & 32,988 & 4,715 & 5,177 & 4,989 & 5,606 & 5,412 \\
\hline 31 & U.S. Treasury, supplementary financing account & 0 & 0 & $299,491^{r}$ & 0 & 0 & 0 & 0 & 0 \\
\hline 32 & Foreign official & 103 & 99 & 121 & 101 & 102 & 100 & 100 & 522 \\
\hline 33 & Service-related & 7,016 & 7,086 & 7,566 & 7,006 & 7,179 & 7,175 & 7,086 & 7,085 \\
\hline 34 & Required clearing balances & 7,016 & 7,086 & 7,566 & 7,006 & 7,176 & 7,175 & 7,086 & 7,085 \\
\hline 35 & Adjustments to compensate for float & 0 & 0 & 0 & 0 & 3 & 0 & 0 & 0 \\
\hline 36 & Other $\ldots \ldots \ldots \ldots \ldots \ldots \ldots \ldots$ & 327 & 298 & 26,277 & 319 & 310 & 385 & 317 & 292 \\
\hline 37 & Other liabilities and capital ${ }^{9}$ & 43,981 & 44,968 & 47,168 & 43,693 & 44,121 & 44,549 & 44,575 & 44,283 \\
\hline 38 & Reserve balances with Federal Reserve Banks & 16,147 & 12,738 & 214,480 & 18,377 & 3,138 & 12,215 & 3,504 & 24,971 \\
\hline
\end{tabular}

NoTE: Some of the data in this table appears in the Board's H.4.1 (503) weekly statistical release, available at www.federalreserve.gov/releases

1. Amounts of vault cash held as reserves are shown in table 1.12 , line 2.

2 . Includes securities lent to dealers under the overnight and term securities lending facilities.

3. Face value of the securities.

4. Compensation that adjusts for the effect of inflation on the original face value of inflation-indexed securities.

5. Cash value of agreements, which are collateralized by U.S. Treasury and federal agency

6. Includes credit extended through Primary Dealer Credit Facility and credit extended to certain other broker-dealers

7. Fair value.

8. Cash value of agreements, which are collateralized by U.S. Treasury securities.

9. Includes the liabilities of Maiden Lane LLC to entities other than the Federal Reserve Bank of New York, including liabilities that have recourse only to the portfolio holdings of Maiden Lane LLC.

10. Excludes required clearing balances and adjustments to compensate for float. 
1.12 RESERVES AND BORROWINGS Depository Institutions ${ }^{1}$

Millions of dollars

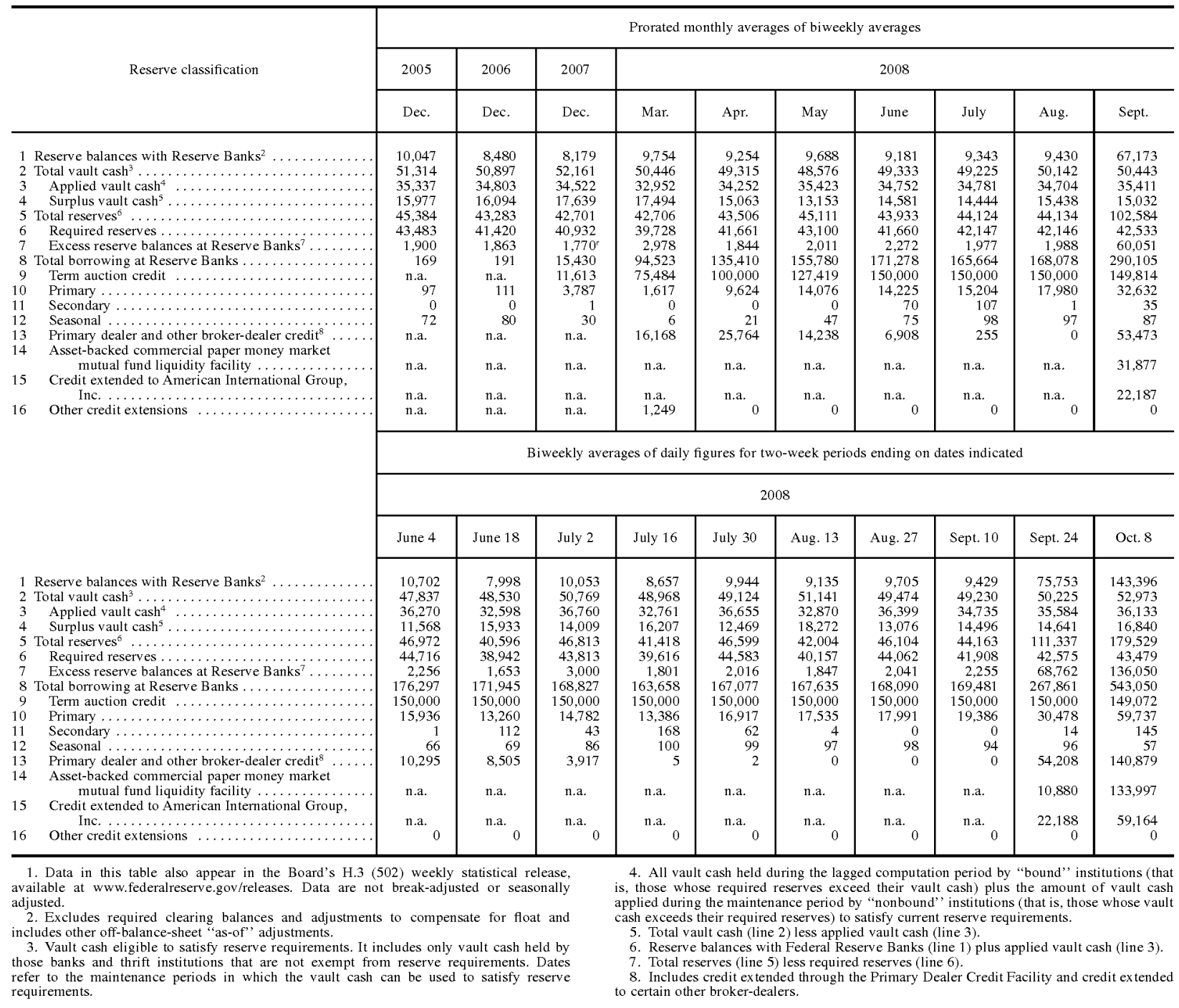


1.14 FEDERAL RESERVE BANK INTEREST RATES

Percent per year

\begin{tabular}{|c|c|c|c|c|c|c|c|c|c|}
\hline \multicolumn{10}{|c|}{ Current and previous levels } \\
\hline \multirow{2}{*}{$\begin{array}{c}\text { Federal Reserve } \\
\text { Bank }\end{array}$} & \multicolumn{3}{|c|}{ Primary credit ${ }^{1}$} & \multicolumn{3}{|c|}{ Secondary credit ${ }^{2}$} & \multicolumn{3}{|c|}{ Seasonal credit ${ }^{3}$} \\
\hline & $\underset{12 / 12 / 08}{\text { On }}$ & Effective date & Previous rate & $\underset{12 / 12 / 08}{\text { On }}$ & Effective date & Previous rate & $\underset{12 / 12 / 08}{\text { On }}$ & Effective date & Previous rate \\
\hline 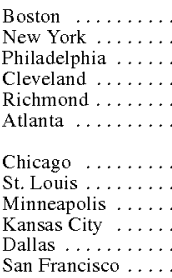 & 1.25 & $\begin{array}{l}10 / 29 / 08 \\
10 / 29 / 08 \\
10 / 30 / 08 \\
10 / 29 / 08 \\
10 / 30 / 08 \\
10 / 31 / 08 \\
10 / 29 / 08 \\
10 / 30 / 08 \\
10 / 30 / 08 \\
10 / 29 / 08 \\
10 / 30 / 08 \\
10 / 29 / 08\end{array}$ & $\overbrace{1.75}^{1.75}$ & 4 & $\begin{array}{l}10 / 29 / 08 \\
10 / 29 / 08 \\
10 / 30 / 08 \\
10 / 29 / 08 \\
10 / 30 / 08 \\
10 / 31 / 08 \\
10 / 29 / 08 \\
10 / 30 / 08 \\
10 / 30 / 08 \\
10 / 29 / 08 \\
10 / 30 / 08 \\
10 / 29 / 08\end{array}$ & $\stackrel{2.25}{4}$ & 1.40 & $\underbrace{}_{12 / 4 / 08}$ & $\stackrel{1.30}{4}$ \\
\hline
\end{tabular}

\begin{tabular}{|c|c|c|c|c|c|c|c|c|}
\hline \multicolumn{9}{|c|}{ Range of rates for primary credit } \\
\hline Effective date & $\begin{array}{l}\text { Range (or } \\
\text { level)-All } \\
\text { F.R. Banks }\end{array}$ & $\begin{array}{c}\text { F.R. Bank } \\
\text { of } \\
\text { N.Y. }\end{array}$ & Effective date & $\begin{array}{l}\text { Range (or } \\
\text { level)-All } \\
\text { F.R. Banks }\end{array}$ & $\begin{array}{c}\text { F.R. Bank } \\
\text { of } \\
\text { N.Y. }\end{array}$ & Effective date & $\begin{array}{l}\text { Range (or } \\
\text { level)-All } \\
\text { F.R. Banks }\end{array}$ & $\begin{array}{c}\text { F.R. Bank } \\
\text { of } \\
\text { N.Y. }\end{array}$ \\
\hline 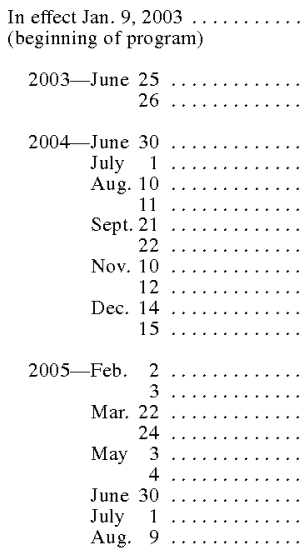 & $\begin{array}{c}2.25 \\
\\
2.00-2.25 \\
2.00 \\
\\
2.00-2.25 \\
2.25 \\
2.25-2.50 \\
2.50 \\
2.50-2.75 \\
2.75 \\
2.75-3.00 \\
3.00 \\
3.00-3.25 \\
3.25 \\
3.25-3.50 \\
3.50 \\
3.50-3.75 \\
3.75 \\
3.75-4.00 \\
4.00 \\
4.00-4.25 \\
4.25 \\
4.25-4.50\end{array}$ & $\begin{array}{l}2.25 \\
\\
2.00 \\
2.00 \\
\\
2.25 \\
2.25 \\
2.50 \\
2.50 \\
2.75 \\
2.75 \\
3.00 \\
3.00 \\
3.25 \\
3.25 \\
3.50 \\
3.50 \\
3.75 \\
3.75 \\
4.00 \\
4.00 \\
4.25 \\
4.25 \\
4.50\end{array}$ & 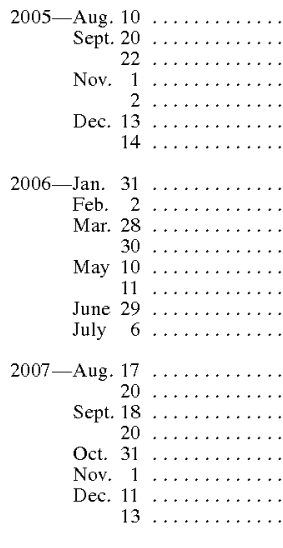 & $\begin{array}{c}4.50 \\
4.50-4.75 \\
4.75 \\
4.75-5.00 \\
5.00 \\
5.00-5.25 \\
5.25 \\
\\
5.25-5.50 \\
5.50 \\
5.50-5.75 \\
5.75 \\
5.75-6.00 \\
6.00 \\
6.00-6.25 \\
6.25 \\
\\
5.75-6.25 \\
5.75 \\
5.25-5.75 \\
5.25 \\
5.00-5.25 \\
5.00 \\
4.75-5.00 \\
4.75\end{array}$ & $\begin{array}{l}4.50 \\
4.75 \\
4.75 \\
5.00 \\
5.00 \\
5.25 \\
5.25 \\
\\
5.50 \\
5.50 \\
5.75 \\
5.75 \\
6.00 \\
6.00 \\
6.25 \\
6.25 \\
5.75 \\
5.75 \\
5.25 \\
5.25 \\
5.00 \\
5.00 \\
4.75 \\
4.75\end{array}$ & 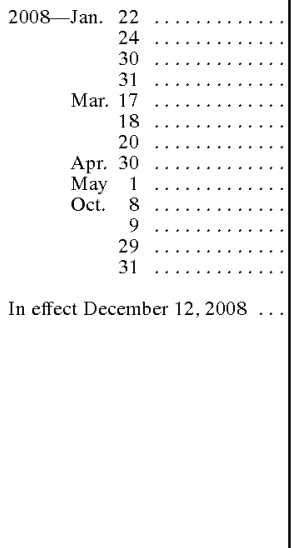 & $\begin{array}{c}4.00-4.75 \\
4.00 \\
3.50-4.00 \\
3.50 \\
3.25-3.50 \\
2.50-3.50 \\
2.50 \\
2.25-2.50 \\
2.25 \\
1.75-2.25 \\
1.75 \\
1.25-1.75 \\
1.25 \\
1.25\end{array}$ & $\begin{array}{l}4.00 \\
4.00 \\
3.50 \\
3.50 \\
3.25 \\
2.50 \\
2.50 \\
2.25 \\
2.25 \\
1.75 \\
1.75 \\
1.25 \\
1.25 \\
1.25\end{array}$ \\
\hline
\end{tabular}

Range of rates for adjustment credit in recent years ${ }^{4}$

\begin{tabular}{|c|c|c|c|c|c|c|c|c|}
\hline Effective date & $\begin{array}{l}\text { Range (or } \\
\text { level)-All } \\
\text { F.R. Banks }\end{array}$ & $\begin{array}{c}\text { F.R. Bank } \\
\text { of } \\
\text { N.Y. }\end{array}$ & Effective date & $\begin{array}{l}\text { Range (or } \\
\text { level)-All } \\
\text { F.R. Banks }\end{array}$ & $\begin{array}{c}\text { F.R. Bank } \\
\text { of } \\
\text { N.Y. }\end{array}$ & Effective date & $\begin{array}{l}\text { Range (or } \\
\text { level)-All } \\
\text { F.R. Banks }\end{array}$ & $\begin{array}{c}\text { F.R. Bank } \\
\text { of } \\
\text { N.Y. }\end{array}$ \\
\hline 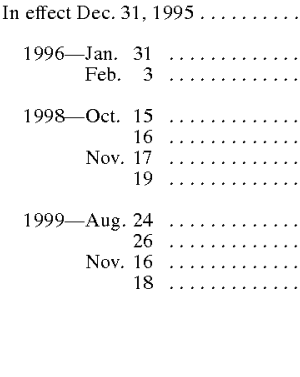 & $\begin{array}{c}5.25 \\
5.00-5.25 \\
5.00 \\
4.75-5.00 \\
4.75 \\
4.50-4.75 \\
4.50 \\
4.50-4.75 \\
4.75 \\
4.75-5.00 \\
5.00\end{array}$ & $\begin{array}{l}5.25 \\
5.00 \\
5.00 \\
\\
4.75 \\
4.75 \\
4.50 \\
4.50 \\
4.75 \\
4.75 \\
4.75 \\
5.00\end{array}$ & 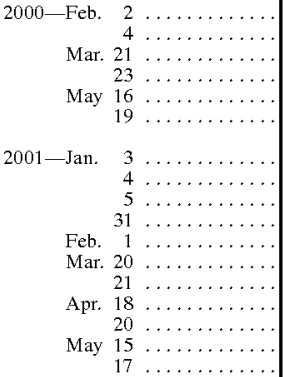 & $\begin{array}{c}5.00-5.25 \\
5.25 \\
5.25-5.50 \\
5.50 \\
5.50-6.00 \\
6.00 \\
\\
5.75-6.00 \\
5.50-5.75 \\
5.50 \\
5.00-5.50 \\
5.00 \\
4.50-5.00 \\
4.50 \\
4.00-4.50 \\
4.00 \\
3.50-4.00 \\
3.50\end{array}$ & $\begin{array}{l}5.25 \\
5.25 \\
5.50 \\
5.50 \\
5.50 \\
6.00 \\
\\
5.75 \\
5.50 \\
5.50 \\
5.00 \\
5.00 \\
4.50 \\
4.50 \\
4.00 \\
4.00 \\
3.50 \\
3.50\end{array}$ & 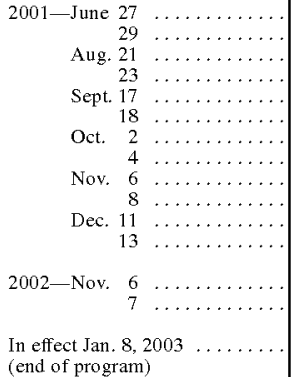 & $\begin{array}{c}3.25-3.50 \\
3.25 \\
3.00-3.25 \\
3.00 \\
2.50-3.00 \\
2.50 \\
2.00-2.50 \\
2.00 \\
1.50-2.00 \\
1.50 \\
1.25-1.50 \\
1.25 \\
0.75-1.25 \\
0.75 \\
0.75\end{array}$ & $\begin{array}{l}3.25 \\
3.25 \\
3.00 \\
3.00 \\
2.50 \\
2.50 \\
2.00 \\
2.00 \\
1.50 \\
1.50 \\
1.25 \\
1.25 \\
0.75 \\
0.75 \\
0.75\end{array}$ \\
\hline
\end{tabular}

1. Available for very short terms as a backup source of liquidity to depository institutions that are in generally sound financial condition in the judgment of the lending Federal Reserve Bank.

2. Available in appropriate circumstances to depository institutions that do not qualify for primary credit.

3. Available to help relatively small depository institutions meet regular seasonal needs for funds that arise from a clear pattern of intrayearly movements in their deposits and loans. The discount rate on seasonal credit takes into account rates charged on market sources of funds and ordinarily is reestablished on the first business day of each two-week reserve maintenance period.

4. Was available until January 8,2003 , to help depository institutions meet temporary needs for funds that could not be met through reasonable alternative sources. For earlier data see the following publications of the Board of Governors: Banking and Monetary Statistics, 1914-1941, and 1941-1970; the Annual Statistical Digest, 1970-1979, 1980-1989, and 1990-1995; and the Statistical Digest, 1996-2000. See also the Board's Statistics: Releases and Historical Data webpages www.federalreserve.gov/releases/H1 5/data.htm. 


\begin{tabular}{|c|c|c|}
\hline \multirow{2}{*}{ Type of liability } & \multicolumn{2}{|c|}{ Requirement } \\
\hline & $\begin{array}{c}\text { Percentage of } \\
\text { liabilities }\end{array}$ & Effective date \\
\hline \multicolumn{3}{|l|}{ Net transaction accounts ${ }^{1}$} \\
\hline 1 \$o million- $\$ 10.3$ million $^{2}$ & 0 & $01 / 01 / 09$ \\
\hline 2 More than $\$ 10.3$ million- $\$ 44.4$ million $^{3}$ & 3 & $01 / 01 / 09$ \\
\hline 3 More than $\$ 44.4$ million $\ldots \ldots \ldots \ldots \ldots \ldots$ & 10 & $01 / 01 / 09$ \\
\hline 4 Nonpersonal time deposits... & 0 & $12 / 27 / 90$ \\
\hline 5 Eurocurrency liabilities ... & 0 & $12 / 27 / 90$ \\
\hline
\end{tabular}

Note: Required reserves must be held in the form of vault cash and, if vault cash is insufficient, also in the form of a deposit with a Federal Reserve Bank. An institution that is a member of the Federal Reserve System must hold that deposit directly with a Reserve Bank; an institution that is not a member of the System can maintain that deposit directly with a Reserve Bank or with another institution in a pass-through relatonshp. Reserve requirements sociations, credit unions, U.S. branches and agencies of foreign ba corporations.

Total transaction accounts consist of demand deposits, automatic transfer service (ATS) accounts, NOW accounts, share draft accounts, telephone or preauthorized transfer accounts, accounts, NOW accounts, share draft accounts, telephone or preauthonized transfer accounts, ineligible acceptances, and obligatons lssued by affliates malting in seven days or less. Ne transaction accounts are total transaction accounts less amoun

For a more detailed description of the

. The alreserve. gov/boarddocs/reportforms. 2. The amount of net transaction accounts subject to a reserve requirement ratio of zero percent (the "exemption amount") is adjusted each year by statute. The exemption amount is adjusted upward by 80 percent of the previous year's (June 30 to June 30 ) rate of increase in total reservable liabilities at all depository institutions. No adjustment is made in the event of
a decrease in such liabilities.

3. The amount of net transaction accounts subject to a reserve requirement ratio of 3 percent is the "low reserve tranche." By statute, the upper limit of the low reserve tranche is adjusted each year by 80 percent of the previous year's (June 30 to June 30 ) rate of increase or decrease in net transaction accounts held by all depository institutions. 
1.17 FEDERAL RESERVE OPEN MARKET TRANSACTIONS ${ }^{\prime}$

Millions of dollars

\begin{tabular}{|c|c|c|c|c|c|c|c|c|c|c|c|}
\hline \multirow{2}{*}{\multicolumn{2}{|c|}{$\begin{array}{l}\text { Type of transaction } \\
\text { and maturity }\end{array}$}} & \multirow{2}{*}{2005} & \multirow{2}{*}{2006} & \multirow{2}{*}{2007} & \multicolumn{7}{|c|}{2008} \\
\hline & & & & & Feb. & Mar. & Apr. & May & June & July & Aug. \\
\hline \multicolumn{12}{|c|}{ U.S. TREASURY SECURITIES ${ }^{2}$} \\
\hline & Outright transactions & & & & & & & & & & \\
\hline 1 & $\begin{array}{l}\text { Ireasury bills } \\
\text { Gross purchases } \ldots \ldots \ldots \ldots \ldots \ldots \ldots \ldots\end{array}$ & 8,300 & 5,748 & 0 & 0 & 0 & 0 & 0 & 0 & 0 & 0 \\
\hline 2 & Gross sales $\ldots \ldots \ldots \ldots \ldots \ldots \ldots \ldots \ldots \ldots \ldots \ldots$ & & & 0 & 0 & 81,398 & 0 & 13,719 & 1,510 & 0 & 0 \\
\hline 3 & Exchanges $\ldots \ldots \ldots \ldots \ldots \ldots \ldots \ldots \ldots$ & 871,661 & 905,206 & 839,688 & 58,896 & 23,501 & 20,060 & 0 & 5,361 & 7,320 & 12,859 \\
\hline 4 & For new bills $\ldots \ldots \ldots \ldots \ldots \ldots \ldots \ldots \ldots$ & 871,661 & 905,206 & 839,688 & 58,896 & 23,501 & 20,060 & 0 & 5,361 & 7,320 & 12,859 \\
\hline 5 & Redemptions... . & 0 & 0 & 49,178 & 0 & 25,977 & 22,667 & 26,529 & 6,819 & 0 & 0 \\
\hline \multicolumn{12}{|c|}{ Others within one year } \\
\hline 6 & Gross purchases ... & 2,894 & 4,967 & 2,211 & 0 & 0 & 0 & 0 & 0 & 0 & 0 \\
\hline 7 & Gross sales $\ldots \ldots \ldots \ldots \ldots \ldots \ldots \ldots \ldots$ & 0 & 0 & 0 & 0 & 0 & 0 & 0 & 0 & 0 & 0 \\
\hline 8 & Maturity shifts $\ldots \ldots \ldots \ldots \ldots \ldots \ldots \ldots \ldots \ldots \ldots$ & 109,557 & 0 & 0 & 0 & 0 & 0 & 0 & 0 & 0 & 0 \\
\hline 9 & Exchanges $\ldots \ldots \ldots \ldots \ldots \ldots \ldots \ldots \ldots$ & $-108,098$ & 0 & 0 & 0 & 0 & 0 & 0 & 0 & 0 & 0 \\
\hline 10 & Redemptions ..... & 2,795 & 10,552 & 1,236 & 0 & 0 & 0 & 1,926 & 0 & 0 & 0 \\
\hline \multicolumn{12}{|c|}{ One to five years } \\
\hline 11 & Gross purchases & 11,309 & 26,354 & 7,539 & 0 & 0 & 0 & 0 & 0 & 0 & 0 \\
\hline 12 & Gross sales .... & & 0 & 0 & 0 & 0 & 0 & 0 & 0 & 0 & 0 \\
\hline 13 & Maturity shifts .... & $-91,121$ & 0 & 0 & 0 & 0 & 0 & 0 & 0 & 0 & 0 \\
\hline 14 & Exchanges $\ldots \ldots \ldots$ & 97,723 & 0 & 0 & 0 & 0 & 0 & 0 & 0 & 0 & 0 \\
\hline \multicolumn{12}{|c|}{ Five to ten years } \\
\hline 15 & Gross purchases & 3,626 & 4,322 & 290 & 0 & 0 & 0 & 0 & 0 & 0 & 0 \\
\hline 16 & Gross sales ..... & & 0 & 0 & 0 & 0 & 0 & 0 & 0 & 0 & 0 \\
\hline 17 & Maturity shifts $\ldots \ldots$. & $-7,041$ & 0 & 0 & 0 & 0 & 0 & 0 & 0 & 0 & 0 \\
\hline 18 & Exchanges $\ldots \ldots \ldots$. & 7,375 & 0 & 0 & 0 & 0 & 0 & 0 & 0 & 0 & 0 \\
\hline \multicolumn{12}{|c|}{ More than ten years } \\
\hline 19 & Gross purchases . & 2,007 & 3,299 & 640 & 0 & 0 & 0 & 0 & 0 & 0 & 0 \\
\hline 20 & Gross sales $\ldots \ldots \ldots \ldots \ldots \ldots \ldots \ldots \ldots \ldots$. & & 0 & 0 & 0 & 0 & 0 & 0 & 0 & 0 & 0 \\
\hline 21 & Maturity shifts $\ldots \ldots \ldots \ldots \ldots \ldots \ldots \ldots$ & $-11,395$ & 0 & 0 & 0 & 0 & 0 & 0 & 0 & 0 & 0 \\
\hline 22 & Exchanges...$\ldots \ldots$ & 3,000 & 0 & 0 & 0 & 0 & 0 & 0 & 0 & 0 & 0 \\
\hline \multicolumn{12}{|c|}{ All maturities } \\
\hline 23 & Gross purchases & 28,136 & 44,690 & 10,680 & 0 & 0 & 0 & 0 & 0 & 0 & 0 \\
\hline 24 & Gross sales ....... & & 0 & 0 & 0 & 96,356 & 20,001 & 33,718 & 1,510 & 0 & 0 \\
\hline 25 & Redemptions ..... & 2,795 & 10,552 & 50,415 & 0 & 25,977 & 22,667 & 28,455 & 6,819 & 0 & 0 \\
\hline 26 & Net change in U.S. Treasury securities & 25,341 & 34,138 & $-39,735$ & 0 & $-122,333$ & $-42,668$ & $-62,173$ & $-8,329$ & 0 & 0 \\
\hline \multicolumn{12}{|c|}{ Federal Agency Obligations } \\
\hline & Outright transactions & & & & & & & & & & \\
\hline 27 & Gross purchases .... & 0 & 0 & 0 & 0 & 0 & 0 & 0 & 0 & 0 & 0 \\
\hline 28 & Gross sales . . . . . . . . . & 0 & 0 & 0 & 0 & 0 & 0 & 0 & 0 & 0 & 0 \\
\hline 29 & Redemptions $\ldots \ldots \ldots \ldots \ldots \ldots \ldots \ldots \ldots$ & 0 & 0 & 0 & 0 & 0 & 0 & 0 & 0 & 0 & 0 \\
\hline 30 & Net change in federal agency obligations & 0 & 0 & 0 & 0 & 0 & 0 & 0 & 0 & 0 & 0 \\
\hline \multicolumn{12}{|c|}{ Temporary TRansactions } \\
\hline & Repurchase agreements ${ }^{3}$ & & & & & & & & & & \\
\hline 31 & Gross purchases & $2,097,050$ & $2,125,500$ & $2,596,750$ & 256,250 & 233,750 & 386,500 & 345,500 & 347,250 & 353,000 & 276,000 \\
\hline 32 & Gross sales ..... & $2,083,300$ & $2,131,500$ & $2,591,000$ & 220,000 & 219,500 & 347,000 & 347,250 & 346,500 & 348,500 & 277,500 \\
\hline & Matched sale-purchase agreements & & & & & & & & & & \\
\hline 33 & Gross purchases $\ldots \ldots \ldots \ldots \ldots \ldots$. & 0 & 0 & 0 & 0 & 0 & 0 & 0 & 0 & 0 & 0 \\
\hline 34 & Gross sales $\ldots \ldots \ldots \ldots \ldots \ldots \ldots \ldots \ldots \ldots$ & 0 & 0 & 0 & 0 & 0 & 0 & 0 & 0 & 0 & 0 \\
\hline & Reverse repurchase agreements ${ }^{4}$ & & & & & & & & & & \\
\hline 35 & Gross purchases $\ldots \ldots \ldots \ldots \ldots$. & $6,421,223$ & $6,779,023$ & $8,662,508$ & 770,268 & 861,490 & 875,902 & 813,259 & 850,374 & 940,787 & 912,593 \\
\hline 36 & Gross sales ... & $6,420,945$ & $6,778,132$ & $8,676,879$ & 773,973 & 862,311 & 872,505 & 811,255 & 855,495 & 942,387 & 909,781 \\
\hline 37 & Net change in temporary transactions $\ldots \ldots \ldots \ldots \ldots$ & 14,028 & $-5,110$ & $-8,621$ & 32,545 & 13,429 & 42,897 & 253 & $-4,372$ & 2,900 & 1,312 \\
\hline 38 & Total net change in System Open Market Account . & 39,369 & 29,029 & $-48,355$ & 32,545 & $-108,905$ & 229 & $-61,920$ & $-12,700$ & 2,900 & 1,312 \\
\hline
\end{tabular}

1. Sales, redemptions, and negative figures reduce holdings of the System Open Market

Account; all other figures increase such holdings.
2. Transactions exclude changes in compensation for the effects of inflation on the 3. Cash value of agreements, which are collateralized by U.S. government and federal principal of inflation-indexed securities. Transactions include the rollover of inflation compen-

4. Cash yalue of agreements, which are collateralized by U.S. Treasury securities.
4. sation into new securities. 
1.18 FEDERAL RESERVE BANKS Condition and Federal Reserve Note Statements ${ }^{1}$ Millions of dollars

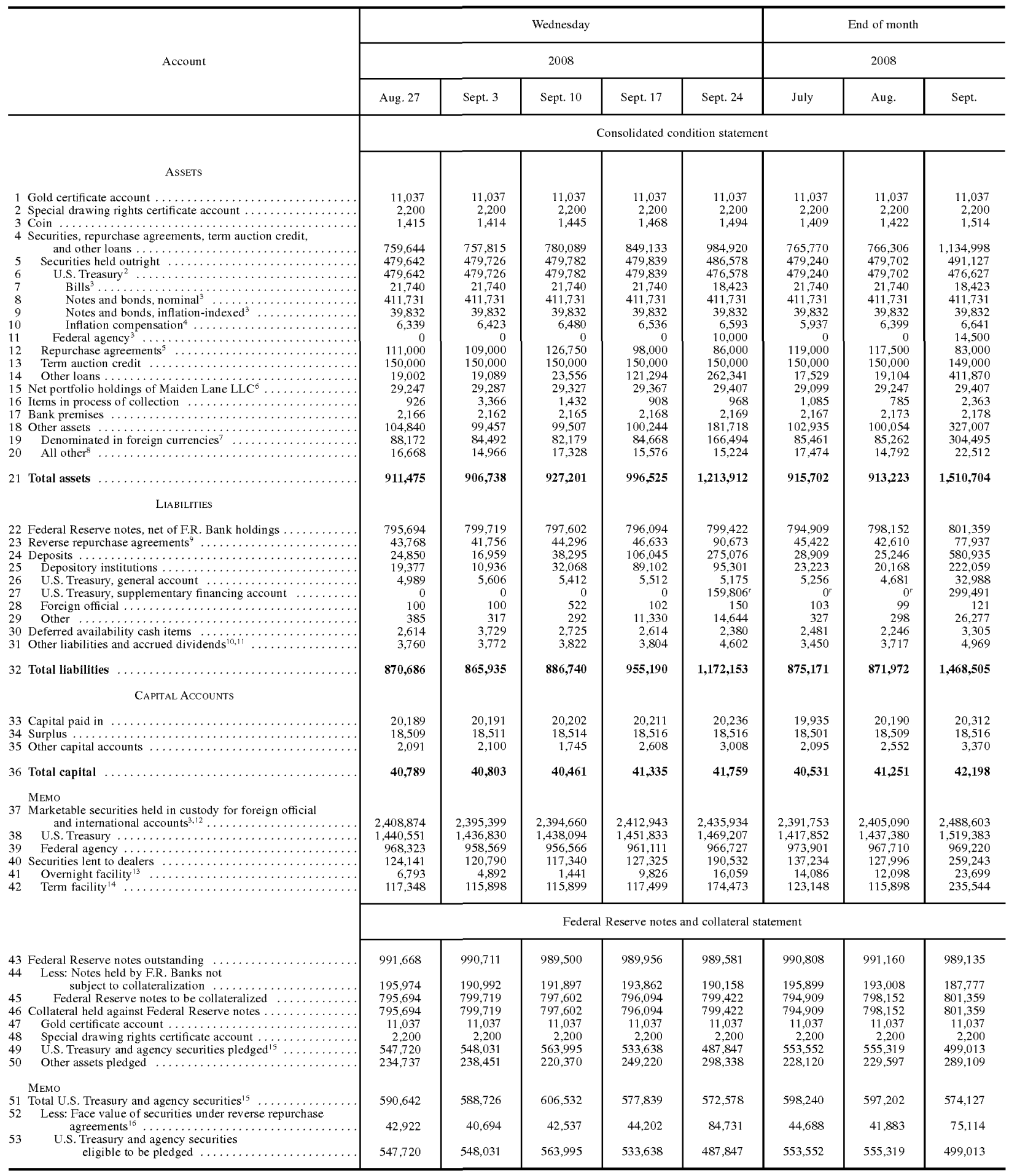

1. Some of the data in this table also appear in the Board's H.4.1 (503) weekly statistical release, which is ayailable at www.federalreserve.gov/releases.

2. Includes securities lent to dealers under the overnight and term securities lending facilities.

Face value of the securities. 4. Compensation that adjusts for the effect of inflation on the original face value of 5 . Cash value securities.

5. Cash value of agreements, which are collateralized by U.S. Treasury and federal agency
securities. securities.
6 . Fair value.

7. Includes any exchange-translation assets, which are revalued daily at market exchange
7. rates.
8. Includes special investment account at the Federal Reserve Bank of Chicago in Treasury 8. Includes special investment
bills maturing within ninety days.

9. Cash value of agreements, which are collateralized by U.S. Treasury securities.

10. Includes any exchange-translation liabilities, which are revalued daily at marke exchange tates.

11. Includes the liabilities of Maiden Lane LLC to entities other than the Federal Reserve Bank of New York, including liabilities that have recourse only to the portfolio holdings of Maiden Lane Luc.

12. Includes U.S. Treasury STRIPs and other zero coupon bonds at face value.

13. Fully collateralized by U.S. Treasury securities.

14. Fully collateralized by U.S. Treasury securities, federal agency securities, and other highly rated debt securities. 15. Includes face value of U.S. Treasury and agency securities held outright, compensation to adjust for the effect of inflation on the original face value of inflation-indexed securities,

16. Face value of agreements, which are fully collateralized by U.S. Treasury securities. 
1.19 FEDERAL RESERVE BANKS Maturity Distribution of Loans and Securities

Millions of dollars

\begin{tabular}{|c|c|c|c|c|c|c|c|c|}
\hline \multirow{3}{*}{ Type of holding and remaining maturity } & \multicolumn{5}{|c|}{ Wednesday } & \multicolumn{3}{|c|}{ End of month } \\
\hline & \multicolumn{5}{|c|}{2008} & \multicolumn{3}{|c|}{2008} \\
\hline & Aug. 27 & Sept. 3 & Sept. 10 & Sept. 17 & Sept. 24 & July & Aug. & Sept. \\
\hline 1 Term auction credit & 150,000 & 150,000 & 150,000 & 150,000 & 150,000 & 150,000 & 150,000 & 149,000 \\
\hline $\begin{array}{l}2 \text { Within } 15 \text { days ... } \\
316 \text { days to } 90 \text { days }\end{array}$ & $\begin{array}{r}125,000 \\
25,000\end{array}$ & $\begin{array}{r}50,000 \\
100,000\end{array}$ & $\begin{array}{r}125,000 \\
25,000\end{array}$ & $\begin{array}{l}75,000 \\
75,000\end{array}$ & $\begin{array}{r}100,000 \\
50,000\end{array}$ & $\begin{array}{l}75,000 \\
75,000\end{array}$ & $\begin{array}{r}50,000 \\
100,000\end{array}$ & $\begin{array}{r}24,000 \\
125,000\end{array}$ \\
\hline 4 Other loans & 19,002 & 19,089 & 23,556 & 121,294 & 262,341 & 17,529 & 19,104 & 411,870 \\
\hline 5 Within 15 days & 3,874 & 4,238 & 8,539 & 101,237 & 135,248 & 3,074 & 3,943 & 209,415 \\
\hline 616 days to 90 days & 15,128 & 14,851 & 15,017 & 20,057 & 77,174 & 14,456 & 15,161 & 120,253 \\
\hline 791 days to 1 year. & 0 & 0 & 0 & 0 & 5,353 & 0 & 0 & 21,123 \\
\hline 8 Over 1 year to 5 years & 0 & 0 & 0 & 0 & 44,566 & 0 & 0 & 61,080 \\
\hline 9 Total U.S. Treasury securities ${ }^{2}$ & 479,642 & 479,726 & 479,782 & 479,839 & 476,578 & 479,240 & 479,702 & 476,627 \\
\hline 10 Within 15 days. & 18,455 & 14,851 & 14,955 & 16,358 & 19,326 & 15,722 & 14,570 & 11,041 \\
\hline 1116 days to 90 days & 28,214 & 31,653 & 31,549 & 30,001 & 23,716 & 28,402 & 32,099 & 26,627 \\
\hline 1291 days to 1 year. & 70,320 & 69,268 & 69,272 & 68,101 & 68,105 & 72,326 & 70,324 & 70,092 \\
\hline 13 Over 1 year to 5 years & 169,539 & 170,789 & 170,807 & 170,676 & 170,694 & 175,535 & 169,558 & 174,100 \\
\hline 14 Over 5 years to 10 years & 91,834 & 91,851 & 91,863 & 93,341 & 93,353 & 89,867 & 91,846 & 93,363 \\
\hline 15 Over 10 years ......... & 101,280 & 101,314 & 101,337 & 101,361 & 101,384 & 97,387 & 101,304 & 101,404 \\
\hline 16 Total federal agency securities ${ }^{3}$ & 0 & 0 & 0 & 0 & 10,000 & 0 & 0 & 14,500 \\
\hline 17 Within 15 days & 0 & 0 & 0 & 0 & 395 & 0 & 0 & 395 \\
\hline 1816 days to 90 days & 0 & 0 & 0 & 0 & 5,632 & 0 & 0 & 9,178 \\
\hline 1991 days to 1 year. & 0 & 0 & 0 & 0 & 3,973 & 0 & 0 & 4,927 \\
\hline 20 Over 1 year to 5 years. & 0 & 0 & 0 & 0 & 0 & 0 & 0 & 0 \\
\hline 21 Over 5 years to 10 years & 0 & 0 & 0 & 0 & 0 & 0 & 0 & 0 \\
\hline 22 Over 10 years. & 0 & 0 & 0 & 0 & 0 & 0 & 0 & 0 \\
\hline 23 Total repurchase agreements ${ }^{3}$ & 111,000 & 109,000 & 126,750 & 98,000 & 86,000 & 119,000 & 117,500 & 83,000 \\
\hline 24 Within 15 days. & 71,000 & 69,000 & 86,750 & 58,000 & 46,000 & 79,000 & 77,500 & 63,000 \\
\hline 2516 days to 90 days & 40,000 & 40,000 & 40,000 & 40,000 & 40,000 & 40,000 & 40,000 & 20,000 \\
\hline 26 Total reverse repurchase agreements ${ }^{3}$ & 43,768 & 41,756 & $\mathbf{4 4 , 2 9 6}$ & 46,633 & 90,673 & 45,422 & 42,610 & $\mathbf{7 7 , 9 3 7}$ \\
\hline 27 Within 15 days. & 43,768 & 41,756 & 44,296 & 46,633 & 90,673 & 45,422 & 42,610 & 77,937 \\
\hline 2816 days to 90 days & 0 & 0 & 0 & 0 & 0 & 0 & 0 & 0 \\
\hline
\end{tabular}

NoTE: Components may not sum to totals because of rounding.

1. Excludes the loan from the Federal Reserve Bank of New York to Maiden Lane LLC that was eliminated when preparing that Bank's statement of condition consistent with
consolidation under generally accepted accounting principles. The loan to Maiden Lane LLC

2. Includes the original face value of inflation-indexed securities and compensation that is desidion under generally accepted accounting principles. The loan to Maiden Lane LLC holdings and does not have a fixed amortization schedule. 


\subsection{AGGREGATE RESERVES OF DEPOSITORY INSTITUTIONS AND MONETARY BASE}

Billions of dollars, averages of daily figures

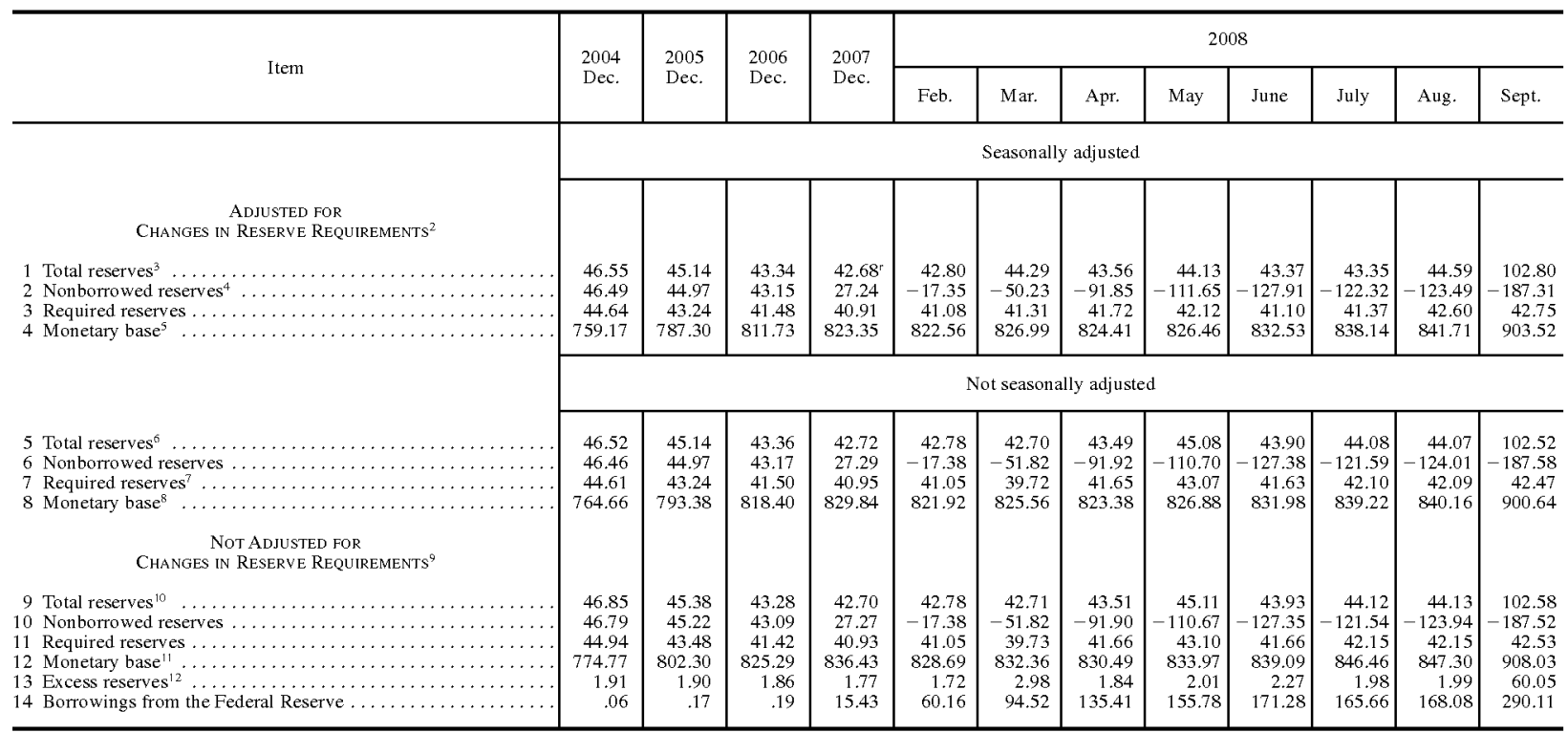

1. Latest monthly and biweekly figures are available from the Board's H.3 (502) weekly statistical release, available at www.federalreserve.gov/releases. Historical data starting in 1959 and estimates of the effect on required reserves of changes in reserve requirements are available from the Monetary and Reserve Analysis Section, Division of Monetary Affairs, Board of Governors of the Federal Reserve System, Washington, DC 20551

2. Figures reflect adjustments for discontinuities, or "breaks," associated with regulatory changes in reserve requirements. (See also table 1.10.)

3. Seasonally adjusted, break-adjusted total reserves equal seasonally adjusted, breakadjusted required reserves (line 3) plus excess reserves (line 13).

4. Seasonally adjusted, break-adjusted nonborrowed reserves equal seasonally adjusted, break-adjusted total reserves (line 1) less total borrowings of depository institutions from the Federal Reserve (line 14).

5. The seasonally adjusted, break-adjusted monetary base consists of (1) seasonally adjusted, break-adjusted total reserves (line 1), plus (2) the seasonally adjusted currency component of the money stock, plus (3) (for all quarterly reporters on the "Report of Transaction Accounts, Other Deposits and Vault Cash" and for all those weekly reporters whose vault cash exceeds their required reserves) the seasonally adjusted, break-adjusted difference between current vault cash and the amount applied to satisfy current reserve requirements.

6. Break-adjusted total reserves equal break-adjusted required reserves (line 7) plus excess reserves (line 13).

7. To adjust required reserves for discontinuities that are due to regulatory changes in reserve requirements, a multiplicative procedure is used to estimate what required reserves would have been in past periods had current reserve requirements been in effect. Breakadjusted required reserves include required reserves against transactions deposits and nonpersonal time and savings deposits (but not reservable nondeposit liabilities)

8. The break-adjusted monetary base equals (1) break-adjusted total reserves (line 5), plus (2) the (unadjusted) currency component of the money stock, plus (3) (for all quarterly reporters on the "Report of Transaction Accounts, Other Deposits and Vault Cash" and for al those weekly reporters whose vault cash exceeds their required reserves) the break-adjusted difference between current vault cash and the amount applied to satisfy current reserve requirements

9 . Reflects actual reserve requirements, including those on nondeposit liabilities, with no adjustments to eliminate the effects of discontinuities associated with regulatory changes in

reserve requirements.
10 . Reserve balances with Federal Reserve Banks plus vault cash used to satisfy reserve requirements.

11. The monetary base, not break-adjusted and not seasonally adjusted, consists of (1) total reserves (line 9), plus (2) required clearing balances and adjustments to compensate for float at Federal Reserve Banks, plus (3) the currency component of the money stock, plus (4) (for all quarterly reporters on the "Report of Transaction Accounts, Other Deposits and Vaul Cash" and for all those weekly reporters whose vault cash exceeds their required reserves) the difference between current vault cash and the amount applied to satisfy current reserve requirements. Since February 1984, currency and vault cash figures have been measured over the computation periods ending on Mondays

12. Unadjusted total reserves (line 9) less unadjusted required reserves (line 11). 
1.21 MONEY STOCK MEASURES '

Billions of dollars, averages of daily figures

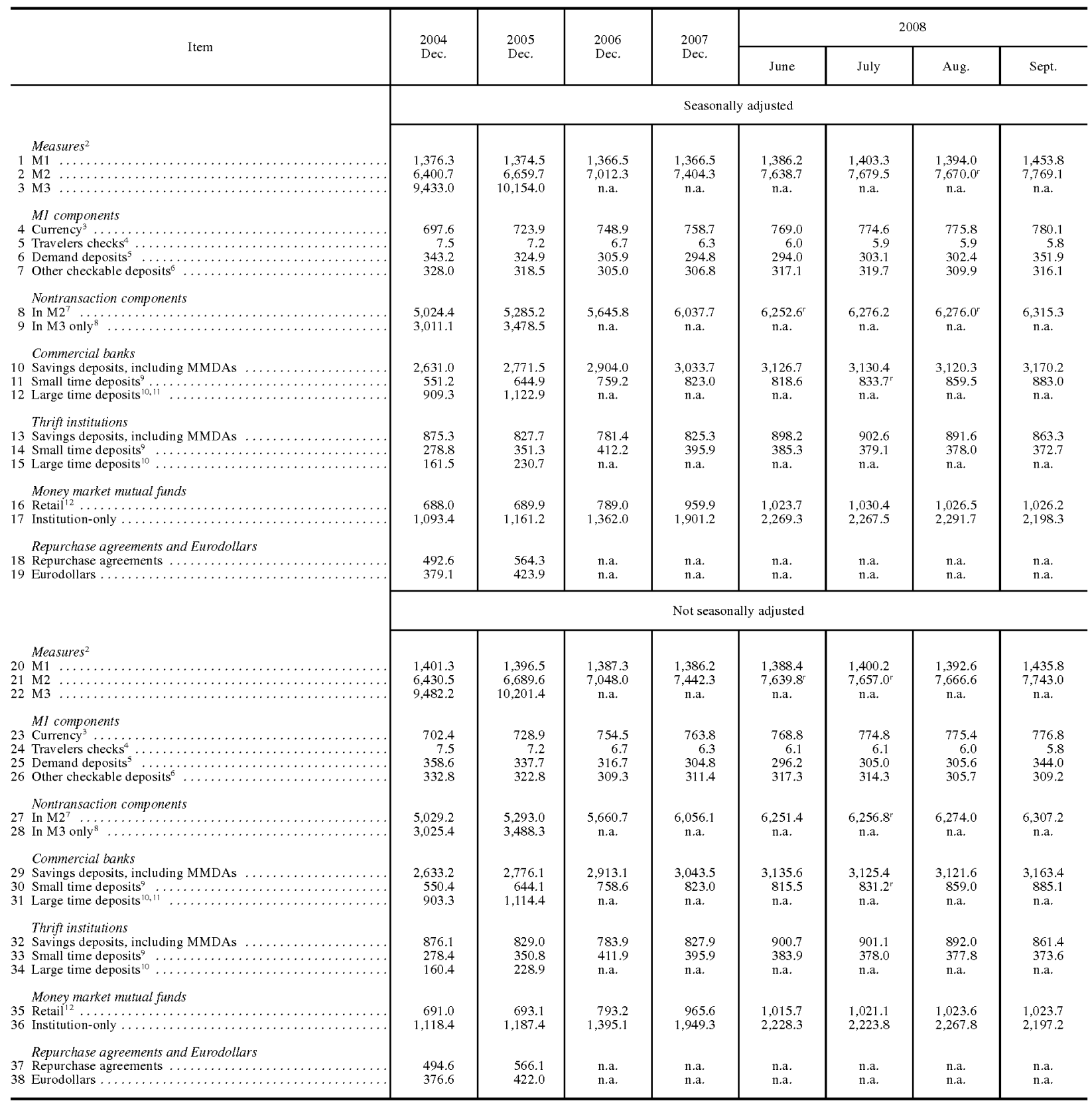

Footnotes appear on following page. 
NOTES TO TABLE 1.21

NoTE: In March 2006, the Board ceased publication of the M3 monetary aggregate and all the components of non-M2 M3 (large time deposits, repurchase agreements, and Eurodollars) except for institutional money funds. Measures of large time deposits will continue to be except for institutional money funds. Measures of large time deposits will continue to be
published by the Board in the Flow of Funds Accounts (Z.1 release) on a quarterly basis and in the H.8 release on a weekly basis (for commercial banks). 1. Latest monthly and weekly figures are available from the Board's H.6 (508) weekly
statistical release, available at www.federalreserve.gov/releases. Historical data starting in statistical release, available at www.federalreserve gov/releases. Historical data starting in 1959 are available from the Monetary and Reserves Analysis Section, Division of Mon
Affairs, Board of Governors of the Federal Reserve System, Washington, DC 20551.

2. Composition of the money stock measures is as follows:
.

2. Composition of the money stock measures is as follows:
M1 consists of (1) currency outside the U.S. Treasury, Federal Reserve Banks, and the vaults of depository institutions; (2) travelers checks of nonbank issuers; (3) demand deposits at commercial banks (excluding those amounts held by depository institutions, the U.S. government, and foreign banks and official institutions) less cash items in the process of collection and Federal Reserve float; and (4) other checkable deposits (OCDs), consisting of collection and Federal Reserve float; and (4) other checkable deposits (OCDs), consisting of
negotiable order of withdrawal (NOW) and automatic transfer service (ATS) accounts at nepository institutions, credit union share draft accounts, and demand deposits at thrift depository institutions, credit union share draft accounts, and demand deposits at thrift
institutions. Seasonally adjusted M1 is constructed by summing currency, travelers checks, institutions. Seasonally adjusted M1 is constructed by summing
demand deposits, and OCDs, each seasonally adjusted separately.

demand deposits, and OCDs, each seasonally adjusted separately. M2 consists of M1 plus (1) savings deposits (including money market deposit accounts);
(2) small-denomination time deposits (time deposits in amounts of less than $\$ 100,000$ ), less (2) small-denomination time deposits (time deposits in amounts of less than $\$ 100,000$ ), less
individual retirement account (IRA) and Keogh balances at depository institutions; and (3) balances in retail money market mutual funds, less IRA and Keogh balances at money marke mutual funds. Seasonally adjusted M2 is constructed by summing savings deposits, smalldenomination time deposits, and retail money fund balances, each seasonally adjusted separately, and adding this result to seasonally adjusted M1.

M3 consists of M2 plus (1) balances in institutional money market mutual funds; (2) large-denomination time deposits (time deposits in amounts of $\$ 100,000$ or more); (3) repurchase agreement (RP) liabilities of depository institutions, in denominations of $\$ 100,000$ or more, on U.S. government and federal agency securities; and (4) Eurodollars held by U.S addressees at foreign branches of U.S. banks worldwide and at all banking offices in the United Kingdom and Canada. Large-denomination time deposits, RPs, and Eurodollars
exclude those amounts held by depository institutions, the U.S. government, foreign banks and official institutions, and money market funds. Seasonally adjusted M3 is constructed by summing institutional money funds, large-denomination time deposits. RPs, and Eurodollars, summing institutional money funds, large-denomination time deposits, RPs, and Eu
each seasonally adjusted separately, and adding the result to seasonally adjusted M2.

3. Currency outside the U.S. Treasury, Federal Reserve Banks, and vaults of depository institutions.

t. Outs. 4. Outstanding amount of U.S. dollar-denominated travelers checks of nonbank
Travelers checks issued by depository institutions are included in demand deposits.

Travelers checks issued by depository institutions are included in demand deposits.
5 . Demand deposits at domestically chartered commercial banks, U.S. branches and 5. Demand deposits at domestically chartered commercial banks, U.S. branches and agencies of foreign banks, and Edge Act corporations (excluding those amounts held by
depository institutions, the U.S. government, and foreign banks and official institutions) less depository institutions, the U.S. government, and foreign banks

6 . Consists of NOW and ATS account balances at all depository institutions, credit union share draft account balances, and demand deposits at thrift institutions.

7. Sum of (1) savings deposits (including MMDAs), (2) small time deposits, and (3) retail money fund balances.

8. Sum of (1) large time deposits, (2) institution-only money fund balances, (3) RPs, and (4) Eurodollars, each seasonally adjusted.

9. Small time deposits are those issued in amounts of less than $\$ 100,000$. All IRAs and Keogh accounts at commercial banks and thrift institutions are subtracted from small time deposits.

10. Large time deposits are those issued in amounts of $\$ 100,000$ or more, excluding those booked at international banking facilities.

11. Large time deposits at domestically chartered commercial banks, U.S. branches and agencies of foreign banks, and Edge Act corporations, excluding those amounts held by depository institutions, the U.S. government, foreign banks and official institutions, and money market mutual funds.

12. IRA and Keogh account balances at money market mutual funds are subtracted from retail money funds. 
1.26 COMMERCIAL BANKS IN THE UNITED STATES Assets and Liabilities ${ }^{1}$

A. All commercial banks

Billions of dollars

\begin{tabular}{|c|c|c|c|c|c|c|c|c|c|c|c|c|}
\hline \multirow{3}{*}{ Account } & \multicolumn{8}{|c|}{ Monthly averages } & \multicolumn{4}{|c|}{ Wednesday figures } \\
\hline & \multirow{2}{*}{$\frac{2007}{\text { Nov. }}$} & \multicolumn{7}{|c|}{2008} & \multicolumn{4}{|c|}{2008} \\
\hline & & Mayr & $J_{\text {June }}^{r}$ & Julyr & Aug.' & Sept.' & Oct.' & Nov. & Noy. 5 & Nov. 12 & Nov. 19 & Noy. 26 \\
\hline & \multicolumn{12}{|c|}{ Seasonally adjusted } \\
\hline Assets & & & & & & & & & & & & \\
\hline 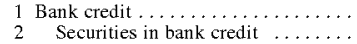 & $\begin{array}{l}9,180.3 \\
2,464.5\end{array}$ & $\begin{array}{l}9,403.3 \\
2,481.2\end{array}$ & $\begin{array}{l}9,374.5 \\
2,471.8\end{array}$ & $\begin{array}{l}9,399.0 \\
2,494.4\end{array}$ & $\begin{array}{l}9,415.2 \\
2,481.1\end{array}$ & $\begin{array}{l}9,575.2 \\
2,537.1\end{array}$ & $\begin{array}{l}9,957.1 \\
2,719.4\end{array}$ & $\begin{array}{l}9,897.9 \\
2,725.8\end{array}$ & $\begin{array}{l}9,866.3 \\
2,692.6\end{array}$ & $\begin{array}{l}9,906.3 \\
2,728.2\end{array}$ & $\begin{array}{l}9,859.1 \\
2,707.4\end{array}$ & $\begin{array}{l}9,904.1 \\
2,720.9\end{array}$ \\
\hline 3 Treasury and Agency securities ${ }^{2}$ & $\begin{array}{l}2,404.5 \\
1,129.0\end{array}$ & $\begin{array}{l}2,48.2 \\
1,096.0\end{array}$ & $1,112.8$ & $1,114.2$ & $\begin{array}{l}2,48.1 \\
1,127.7\end{array}$ & $1,153.8$ & $1,227.0$ & $1,261.2$ & $\begin{array}{l}2,062.6 \\
1,270.8\end{array}$ & $1,278.8$ & $1,241.9$ & $1,252.3$ \\
\hline $\begin{array}{l}\text { Other securities } \\
\text { Othes }\end{array}$ & $1,335.5$ & $\begin{array}{l}1,385.3 \\
1,380\end{array}$ & $\begin{array}{l}1,12.8 \\
1,359.0\end{array}$ & $1,380.2$ & $1,353.4$ & $1,383.3$ & $1,492.4$ & $\begin{array}{l}1,261.2 \\
1,464.6\end{array}$ & $\begin{array}{l}1,2,40.8 \\
1,421.8\end{array}$ & $1,449.4$ & $1,465.6$ & $1,468.6$ \\
\hline 5 Loans and leases in bank credit ${ }^{3}$ & $6,715.8^{r}$ & $6,922.0$ & $\begin{array}{l}1,3002.7 \\
6,902.7\end{array}$ & $\begin{array}{l}1,300.2 \\
6,904.6\end{array}$ & $6,934.1$ & $\begin{array}{l}1,03038.1 \\
7,038.1\end{array}$ & $7,237.7$ & $\begin{array}{l}1,172.1 \\
7,172.0\end{array}$ & $7,173.7$ & $7,178.1$ & $7,151.7$ & $7,183.2$ \\
\hline 6 Commercial and industrial ... & $1,408.5^{r}$ & $1,496.3$ & $1,503.1$ & $1,508.5$ & $1,508.3$ & $1,536.1$ & $1,600.1$ & $1,596.4$ & $1,596.6$ & $1,604.1$ & $1,589.2$ & $1,599.6$ \\
\hline Real estate .... & $3,562.3^{r}$ & $\begin{array}{l}1,490.93 \\
3,657.2\end{array}$ & $3,648.2$ & $\begin{array}{l}1,627.0 \\
3,6\end{array}$ & $3,645.9$ & $3,666.5$ & $3,791.4$ & $3,784.3$ & $\begin{array}{l}3,776.0 \\
3,776\end{array}$ & $3,785.9$ & $3,777.4$ & $3,790.3$ \\
\hline Revolving home equity & 478.5 & 512.2 & 518.4 & 523.5 & 526.2 & 540.4 & 577.8 & 580.5 & $5,58.2$ & 578.6 & 580.0 & 582.2 \\
\hline Other ................ & $3,083.7^{\prime}$ & $3,145.1$ & $3,129.9$ & $3,103.5$ & $3,119.7$ & $3,126.1$ & $3,213.6$ & $3,203.8$ & $3,197.7$ & $3,207.3$ & $3,197.5$ & $3,208.1$ \\
\hline Consumer & 795.9 & 827.1 & 831.7 & 839.3 & 845.0 & 852.0 & 870.7 & 876.3 & 871.4 & 872.2 & 875.7 & 880.9 \\
\hline Security ${ }^{4}$. & 282.0 & 292.8 & 280.8 & 295.0 & 305.5 & 331.0 & 302.6 & 269.7 & 273.3 & 263.9 & 276.2 & 271.1 \\
\hline Other loans and leases & 667.1 & 648.5 & 638.8 & 634.8 & 629.3 & 652.4 & 672.9 & 645.4 & 656.4 & 652.0 & 633.2 & 641.2 \\
\hline 13 Interbank loans . . . . . . . . & 421.5 & 446.6 & 453.1 & 437.7 & 434.2 & 462.6 & 444.6 & 344.8 & 382.0 & 343.8 & 334.5 & 324.4 \\
\hline 14 Cash assets $^{5}$ & 302.3 & 306.5 & 300.0 & 296.6 & 297.8 & 368.5 & 576.5 & 851.5 & 784.8 & 863.3 & 858.5 & 866.3 \\
\hline 15 Other assets ${ }^{6}$ & 953.5 & 987.9 & $1,003.9$ & $1,019.0$ & $1,018.5$ & $1,042.0$ & $1,087.6$ & $1,131.9$ & $1,095.0$ & $1,108.9$ & $1,146.2$ & $1,151.7$ \\
\hline 16 Total assets ${ }^{7}$ & $10,784.2$ & $11,047.3$ & $11,030.6$ & $11,044.8$ & $11,056.6$ & $11,335.0$ & $11,943.3$ & $12,099.9$ & $12,002.4$ & $12,095.9$ & $12,072.1$ & $12,121.2$ \\
\hline Liabilities & & & & & & & & & & & & \\
\hline 17 Deposits ..... & $6,637.8$ & $6,887.0$ & $6,909.6$ & $6,884.1$ & $6,914.3$ & $7,072.5$ & $7,125.1$ & $7,063.6$ & $7,084.5$ & $7,077.5$ & $6,991.2$ & $7,101.7$ \\
\hline 18 Transaction ... & 610.9 & 613.4 & 603.6 & 621.0 & 600.2 & 640.2 & 679.4 & 707.4 & & & & 700.1 \\
\hline 19 Nontransaction & $6,027.0$ & $6,273.6$ & $6,306.0$ & $6,263.2$ & $6,314.0$ & $6,432.3$ & $6,445.7$ & $6,356.2$ & $6,353.5$ & $6,375.4$ & $6,309.4$ & $6,401.6$ \\
\hline Large time & $2,026.6$ & $2,112.8$ & $2,125.5$ & $2,131.0$ & $2,129.9$ & $2,161.0$ & $2,065.5$ & $1,944.1$ & $1,986.7$ & $1,949.7$ & & $1,933.7$ \\
\hline $21 \quad$ Other & $4,000.4$ & $4,160.9$ & $4,180.4$ & $4,132.1$ & $4,184.1$ & $4,271.3$ & $4,380.3$ & $4,412.1$ & $4,366.8$ & $4,425.7$ & $4,378.6$ & $4,467.9$ \\
\hline 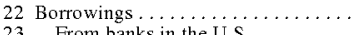 & $2,221.4$ & $2,319.1$ & $2,316.9$ & $2,340.5$ & $2,357.2$ & $2,398.6$ & $2,619.8$ & $2,601.3$ & $2,589.5$ & $2,655.9$ & $2,609.7$ & $2,565.1$ \\
\hline 23 From banks in the U.S. & 456.7 & 483.9 & 483.4 & 479.6 & 477.0 & 478.6 & 458.5 & 404.6 & 413.7 & 409.5 & 401.4 & 401.7 \\
\hline 24 From others & $1,764.7$ & $1,835.2$ & $1,833.5$ & $1,860.9$ & $1,880.1$ & $1,920.0$ & $2,161.3$ & $2,196.7$ & $2,175.8$ & $2,246.4$ & $2,208.3$ & $2,163.4$ \\
\hline $\begin{array}{l}25 \text { Net due to related foreign offices } \\
26 \text { Other liabilities ................ }\end{array}$ & $\begin{array}{r}85.9 \\
665.9\end{array}$ & $\begin{array}{r}-23.6 \\
693.4\end{array}$ & $\begin{array}{r}-18.5 \\
674.5\end{array}$ & $\begin{array}{r}-46.9 \\
674.5\end{array}$ & $\begin{array}{r}-92.2 \\
673.3\end{array}$ & $\begin{array}{r}-61.8 \\
715.1\end{array}$ & $\begin{array}{l}180.2 \\
805.9\end{array}$ & $\begin{array}{l}389.2 \\
840.6\end{array}$ & $\begin{array}{l}337.6 \\
787.9\end{array}$ & $\begin{array}{r}3879.9 \\
7994\end{array}$ & $\begin{array}{l}430.0 \\
852.8\end{array}$ & $\begin{array}{l}378.5 \\
875.3\end{array}$ \\
\hline 27 Total liabilities & $9,611.1$ & $9,875.9$ & $9,882.5$ & $9,852.2$ & $9,852.6$ & $10,124.4$ & $10,731.0$ & $10,894.8$ & $10,799.6$ & $10,920.7$ & $10,883.7$ & $10,920.6$ \\
\hline 28 Residual (assets less liabilities) ${ }^{8}$ & $1,173.1$ & $1,171.3$ & $1,148.2$ & $1,192.6$ & $1,204.0$ & $1,210.6$ & $1,212.3$ & $1,205.1$ & $1,202.8$ & $1,175.2$ & $1,188.3$ & $1,200.6$ \\
\hline & \multicolumn{12}{|c|}{ Not seasonally adjusted } \\
\hline $\begin{array}{l}\text { Assets } \\
\text { An }\end{array}$ & & & & & & & & & & & & \\
\hline $\begin{array}{l}29 \text { Bank credit ..... } \\
30 \text { Securities in ba }\end{array}$ & $9,225.9^{r}$ & $9,385.7$ & $\begin{array}{l}9,340.8 \\
2,4850\end{array}$ & $9,329.0$ & $9,348.8$ & $9,553.6$ & $9,964.4$ & $9,953.1$ & $\begin{array}{l}9,931.2 \\
27079\end{array}$ & $9,944.9$ & $9,910.7$ & $9,967.7$ \\
\hline 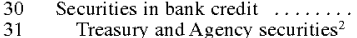 & $\begin{array}{l}2,468.7 \\
1,123.1\end{array}$ & $\begin{array}{l}2,306.4 \\
1,110.0\end{array}$ & $\begin{array}{l}2,485.0 \\
1.123 .5\end{array}$ & $\begin{array}{l}2,416.4 \\
1.118 .5\end{array}$ & $\begin{array}{l}2,4653.5 \\
1,133.0\end{array}$ & $\begin{array}{l}2,516.4 \\
1,146.2\end{array}$ & $\begin{array}{l}2,702.1 \\
1,212.5\end{array}$ & $\begin{array}{l}2,733.3 \\
1,257.0\end{array}$ & $\begin{array}{l}2,7,27.9 \\
1.275 .4\end{array}$ & $1,271.1$ & $1,237.5$ & $\begin{array}{l}2,736.1 \\
1.246 .2\end{array}$ \\
\hline 32 & $1,345.6$ & $1,396.4$ & $1,361.5$ & $1,357.8$ & 1.3 & 1,37 & 1.48 & 1.478 .3 & 1.432 .5 & & 1.4 & 1.490 .0 \\
\hline in bank credit & 6,75 & 6,87 & 6,85 & $6,852.6$ & & 7,0 & 7,2 & & $7,223.3$ & & & $7,231.5$ \\
\hline nd indust & $1,409.7^{r}$ & 1,49 & 1,49 & $1,497.4$ & & 1,5 & & & 1,5 & & & $1,605.4$ \\
\hline Real & 3,60 & 3,62 & 3,61 & & 3,61 & 3,66 & 3,82 & 3,8 & 3,8 & & 3,81 & $3,829.3$ \\
\hline g home equity & 48 & & & & & 54 & & & & & & 587.5 \\
\hline $\mathrm{O}$ & 3,11 & 3,11 & 3,10 & & 3,08 & 3,12 & 3,24 & 3,2 & 3,2 & 3,2 & 3,23 & $3,241.8$ \\
\hline Const & & & & & & & & & & & & 882.1 \\
\hline cards and related plans & & & & & & & & & & & & 386 \\
\hline 40 & & & & & & & & & & & & 49 \\
\hline $\mathrm{Se}$ & & & & & & & & & & & & 27 \\
\hline$s$ and leases & & 64 & & & & & & & & & & 644.2 \\
\hline 43 Interbank & 433.7 & & 435 & 422.1 & & & 44 & & & & & 330.8 \\
\hline 44 Cash & 307.4 & 304.1 & & & & & & & & & & 878.1 \\
\hline 45 Other assets $^{6}$ & 950.5 & 985.1 & 999.2 & $1,016.1$ & $1,014.8$ & $1,050.6$ & $1,096.9$ & $1,130.4$ & $1,095.1$ & $1,115.2$ & $1,136.8$ & $1,151.2$ \\
\hline 46 Total assets ${ }^{7}$ & $10,844.7$ & $11,011.7$ & $\mathbf{1 0 , 9 7 1 . 2}$ & $10,951.8$ & $10,967.0$ & $11,317.4$ & $11,957.9$ & $12,177.1$ & $12,058.7$ & $12,172.4$ & $12,154.5$ & $12,204.8$ \\
\hline Liabilities & & & & & & & & & & & & \\
\hline Devest & $6,676.3$ & $6,862.0$ & $6,864.5$ & $6,831.0$ & $6,844.2$ & $7,052.3$ & $7,145.1$ & $7,117.4$ & $7,135.3$ & $7,144.6$ & $7,062.4$ & $7,115.0$ \\
\hline $\mathrm{T}$ & & 60 & & & & & & & & & 706.3 & 770.7 \\
\hline Nontran & $6,062.4$ & 6,25 & 6,26 & 6,22 & & 6,42 & 6,4 & 6,4 & 6,4 & 6,4 & & $6,344.3$ \\
\hline $50 \quad$ Large ti & $\begin{array}{l}0,002.4 \\
2,032.8\end{array}$ & 2,13 & $\begin{array}{l}0,20 \\
2,12\end{array}$ & 2,09 & & $\begin{array}{l}0,4 \\
2,1\end{array}$ & $\begin{array}{l}0,4 \\
2,07\end{array}$ & & & & & $\begin{array}{l}0,939.8 \\
1,939.8\end{array}$ \\
\hline Other & $4,029.6$ & $4,122.4$ & $4,136.2$ & $4,132.3$ & $4,151.6$ & $4,273.2$ & 4,40 & $\begin{array}{l}4,4 \\
4,4\end{array}$ & 4,46 & $4,502.1$ & $\begin{array}{l}1,9,4 \\
4,4\end{array}$ & $\begin{array}{l}4,404.5 \\
4,59.0\end{array}$ \\
\hline 52 Borrowings & $2,221.5$ & $2,338.7$ & $2,318.3$ & $2,307.1$ & $2,343.1$ & $2,414.2$ & 2,61 & 2,60 & $2,604.3$ & $2,647.9$ & $2,598.7$ & $2,576.1$ \\
\hline 53 From banks in the U.S. & 462.2 & 481.0 & $\begin{array}{ll}2,10.3 \\
479.3\end{array}$ & 467.3 & $\begin{array}{r}2,343.1 \\
469.9\end{array}$ & $\begin{array}{r}2,14.2 \\
477.9\end{array}$ & $\begin{array}{l}2,01 \\
45\end{array}$ & 40 & $\begin{array}{r}412.6 \\
412.6\end{array}$ & 411.3 & 405.1 & 408.3 \\
\hline 54 From other & $1,759.3$ & $1,857.7$ & 1,83 & $1,839.8$ & $1,873.2$ & $1,936.3$ & 2,16 & 2,19 & $2,191.7$ & $2,236.6$ & $2,193.7$ & $2,167.8$ \\
\hline 55 Net due to related foreign offices & 95.1 & -64.5 & -52.3 & -23.3 & -66.3 & -47.9 & 195.2 & 399.0 & 329.8 & 383.3 & 433.2 & $\begin{array}{r}4,100.9 \\
420.9\end{array}$ \\
\hline 56 Other liabilities & 682.8 & 699.3 & 667.3 & 666.1 & 671.4 & 712.7 & 811.8 & 862.7 & 811.8 & 813.8 & 869.4 & 907.4 \\
\hline 57 Total liabilities & $9,675.7$ & $9,835.5$ & $9,797.8$ & $9,780.9$ & $9,792.4$ & $10,131.2$ & $10,769.6$ & $10,980.0$ & $10,881.2$ & $10,989.6$ & $10,963.8$ & $11,019.4$ \\
\hline 58 Residual (assets less liabilities) & $1,169.0$ & $1,176.2$ & $1,173.4$ & $1,170.9$ & $1,174.6$ & $1,186.1$ & $1,188.3$ & $1,197.2$ & $1,177.5$ & $1,182.8$ & $1,190.7$ & $1,185.4$ \\
\hline
\end{tabular}

Footnotes appear on p. 21. 
16 Federal Reserve Bulletin Statistical Supplement $\square$ December 2008

1.26 COMMERCIAL BANKS IN THE UNITED STATES Assets and Liabilities ${ }^{1}$ —Continued

B. Domestically chartered commercial banks

Billions of dollars

\begin{tabular}{|c|c|c|c|c|c|c|c|c|c|c|c|c|c|}
\hline \multirow{3}{*}{\multicolumn{2}{|c|}{ Account }} & \multicolumn{8}{|c|}{ Monthly averages } & \multirow{2}{*}{\multicolumn{4}{|c|}{$\begin{array}{c}\text { Wednesday figures } \\
2008\end{array}$}} \\
\hline & & \multirow{2}{*}{$\begin{array}{c}2007 \\
\text { Nov. }\end{array}$} & \multicolumn{7}{|c|}{2008} & & & & \\
\hline & & & May $^{r}$ & June $^{r}$ & July ${ }^{r}$ & Aug.' & Sept. & Oct. ${ }^{r}$ & Nov. & Noy. 5 & Nov. 12 & Nov. 19 & Noy. 26 \\
\hline & & \multicolumn{12}{|c|}{ Seasonally adjusted } \\
\hline \multicolumn{14}{|c|}{ Assets } \\
\hline 1 & Bank credit. & $8,026.1^{r}$ & $8,268.2$ & $8,253.0$ & $8,276.4$ & $8,291.1$ & $8,456.5$ & $8,804.2$ & $8,779.0$ & $8,746.1$ & $8,764.9$ & $8,734.8$ & $8,807.5$ \\
\hline 2 & Securities in bank credit & $1,990.3$ & $2,014.4$ & $2,014.6$ & $2,026.4$ & $2,016.6$ & $2,082.3$ & $2,244.2$ & $2,261.7$ & $2,232.3$ & $2,249.8$ & $2,233.8$ & $2,273.2$ \\
\hline 3 & Treasury and Agency securities ${ }^{2}$ & $1,036.3$ & $1,004.1$ & $1,021.2$ & $1,020.5$ & $1,040.9$ & $1,070.9$ & $1,151.4$ & $1,177.8$ & $1,184.5$ & $1,191.7$ & $1,160.9$ & $1,172.2$ \\
\hline 4 & Other securities & 954.0 & $1,010.3$ & 993.4 & $1,005.9$ & 975.6 & $1,011.5$ & $1,092.8$ & $1,083.9$ & $1,047.7$ & $1,058.1$ & $1,072.9$ & $1,101.0$ \\
\hline 5 & Loans and leases in bank credit ${ }^{3}$ & $6,035.8^{r}$ & $6,253.7$ & $6,238.4$ & $6,250.0$ & $6,274.5$ & $6,374.2$ & $6,560.0$ & $6,517.3$ & $6,513.8$ & $6,515.0$ & $6,501.0$ & $6,534.3$ \\
\hline 6 & Commercial and industrial ... & $1,133.5^{r}$ & $1,185.4$ & $1,189.9$ & $1,194.0$ & $1,191.4$ & $1,209.8$ & $1,249.3$ & $1,243.5$ & $1,243.9$ & $1,250.5$ & $1,238.1$ & $1,246.1$ \\
\hline 7 & Real estate..$\ldots \ldots \ldots$. & $3,526.6^{r}$ & $3,616.5$ & $3,606.1$ & $3,584,2$ & $3,601.7$ & $3,623.5$ & $3,750.6$ & $3,745.2$ & $3,737.1$ & $3,746.8$ & $3,738.6$ & $3,751.0$ \\
\hline 8 & Revolving home equity & 478.5 & 512.2 & 518.4 & 523.5 & 526.2 & 540.4 & 577.8 & 580.5 & 578.2 & 578.6 & 580.0 & 582.2 \\
\hline 9 & Other ............. & $3,048.1^{r}$ & $3,104.3$ & $3,087.8$ & $3,060.7$ & $3,075.6$ & $3,083.1$ & $3,172.8$ & $3,164.8$ & $3,158.9$ & $3,168.2$ & $3,158.6$ & $3,168.8$ \\
\hline 10 & Consumer & 795.9 & 827.1 & 831.7 & 839.3 & 845.0 & 852.0 & 870.7 & 876.3 & 871.4 & 872.2 & 875.7 & 880.9 \\
\hline 11 & Security ${ }^{4}$. & 141.4 & 189.0 & 180.4 & 194.7 & 204.8 & 241.3 & 230.6 & 213.1 & 213.2 & 205.8 & 217.5 & 218.0 \\
\hline 12 & Other loans and leases & $438.5^{r}$ & 435.8 & 430.2 & 437.7 & 431.6 & 447.6 & 458.8 & 439.2 & 448.2 & 439.7 & 431.1 & 438.2 \\
\hline 13 & Interbank loans .......... & 342.5 & 371.6 & 384.7 & 372.0 & 368.2 & 394.4 & 383.8 & 298.4 & 339.0 & 300.0 & 284.3 & 275.4 \\
\hline 14 & Cash assets $^{5} \ldots$ & 245.5 & 248.4 & 240.4 & 240.5 & 244.7 & 307.7 & 446.5 & 577.8 & 541.4 & 607.0 & 544.4 & 593.1 \\
\hline 15 & Other assets ${ }^{6}$ & 904.5 & 938.6 & 947.6 & 970.5 & 975.5 & 995.3 & $1,027.0$ & $1,077.6$ & $1,035.0$ & $1,056.3$ & $1,091.6$ & $1,099.7$ \\
\hline 16 & Total assets ${ }^{7}$ & $9,445.2^{\mathrm{r}}$ & $9,729.8$ & $9,724.8$ & $9,751.9$ & $9,770.3$ & $10,040.7$ & $10,538.9$ & $10,606.5$ & $10,536.0$ & $10,602.0$ & $10,529.1$ & $10,650.4$ \\
\hline & Liabilities & & & & & & & & & & & & \\
\hline 17 & Deposits. & $5,620.3$ & $5,774.3$ & $5,784.9$ & $5,763.3$ & $5,786.7$ & $5,969.6$ & $6,194.5$ & $6,201.4$ & $6,181.4$ & $6,213.2$ & $6,130.3$ & $6,261.0$ \\
\hline 18 & Transaction & 597.8 & 596.4 & 586.8 & 603.8 & 583.7 & 621.1 & 657.0 & 689.0 & 712.4 & 683.8 & 662.5 & 682.5 \\
\hline 19 & Nontransaction & $5,022.5$ & $5,177.9$ & $5,198.1$ & $5,159.5$ & $5,203.0$ & $5,348.6$ & $5,537.5$ & $5,512.4$ & $5,469.0$ & $5,529.4$ & $5,467.8$ & $5,578.5$ \\
\hline 20 & Large time. & $1,024.3$ & $1,021.4$ & $1,022.1$ & $1,030.5$ & $1,023.4$ & $1,082.2$ & $1,160.3$ & $1,104.1$ & $1,104.9$ & $1,106.4$ & $1,091.9$ & $1,116.6$ \\
\hline 21 & Other .... & $3,998.2$ & $4,156.5$ & $4,176.0$ & $4,128.9$ & $4,179.6$ & $4,266.3$ & $4,377.2$ & $4,408.3$ & $4,364.1$ & $4,423.0$ & $4,375.9$ & $4,461.9$ \\
\hline 22 & Borrowings. & $1,634.7$ & $1,711.7$ & $1,714.0$ & $1,735.4$ & $1,753.6$ & $1,791.6$ & $2,000.9$ & $1,993.9$ & $1,996.8$ & $2,041.0$ & $1,981.8$ & $1,968.6$ \\
\hline 23 & From banks in the U.S. & 396.0 & 412.0 & 413.7 & 406.7 & 409.6 & 394.6 & 400.6 & 364.8 & 377.9 & 370.3 & 365.2 & 355.0 \\
\hline 24 & From others ..... & $1,238.7$ & $1,299.7$ & $1,300.3$ & $1,328.7$ & $1,344.0$ & $1,397.0$ & $1,600.3$ & $1,629.2$ & $1,618.9$ & $1,670.7$ & $1,616.6$ & $1,613.6$ \\
\hline 25 & Net due to related foreign offices & 482.0 & 527.7 & 546.2 & 529.7 & 509.8 & 506.3 & 512.8 & 556.6 & 556.7 & 555.6 & 563.6 & 543.3 \\
\hline 26 & Other liabilities $\ldots \ldots \ldots$. & 537.2 & 547.6 & 534.3 & 537.3 & 532.8 & 567.0 & 622.5 & 654.8 & 607.3 & 619.6 & 661.6 & 686.6 \\
\hline 27 & Total liabilities & $8,274.2$ & $8,561.2$ & $8,579.4$ & $8,565.7$ & $8,582.9$ & $8,834.5$ & $9,330.7$ & $9,406.8$ & $9,342.3$ & $9,429.5$ & $9,337.3$ & $9,459.5$ \\
\hline \multirow[t]{3}{*}{28} & Residual (assets less liabilities) ${ }^{8}$ & $1,171.0^{\mathrm{r}}$ & $1,168.6$ & $1,145.4$ & $1,186.1$ & $1,187.3$ & $1,206.2$ & $1,208.2$ & $1,199.7$ & $1,193.7$ & $1,172.5$ & $1,191.8$ & $1,190.9$ \\
\hline & & & & & & & Not season & ly adjusted & & & & & \\
\hline & Assets & & & & & & & & & & & & \\
\hline 29 & Bank credit . & $8,063.2^{r}$ & $8,255.7$ & $8,227.1$ & $8,225.2$ & $8,238.3$ & $8,443.1$ & $8,813.5$ & $8,826.3$ & $8,804.1$ & $8,802.4$ & $8,782.0$ & $8,855.2$ \\
\hline 30 & Securities in bank credit & $1,988.4$ & $2,036.4$ & $2,026.5$ & $2,016.4$ & $2,006.7$ & $2,066.1$ & $2,228.8$ & $2,265.1$ & $\begin{array}{l}0,004.1 \\
2,241.0\end{array}$ & $2,245.1$ & $2,236.3$ & $\begin{array}{l}0,050.2 \\
2,279.8\end{array}$ \\
\hline 31 & Treasury and Agency securities ${ }^{2}$ & $1,029.9$ & $1,017.9$ & $1,032.5$ & $1,026.5$ & $1,045.1$ & $1,062.4$ & $1,136.3$ & $1,173.3$ & $1,188.9$ & $1,183.8$ & $1,156.9$ & $1,165.6$ \\
\hline 32 & Other securities ........... & 958.5 & 1.018 .6 & 993.9 & 989.9 & 961.5 & $1,003.7$ & $1,092.5$ & $1,091.8$ & $1,052.1$ & 1.061 .3 & 1.079 .5 & $1,114.2$ \\
\hline 33 & Loans and leases in bank credit ${ }^{3}$ & $6,074.8$ & $6,219.2$ & $6,200.6$ & $6,208.8$ & $6,231.7$ & $6,377.0$ & 6.584 .8 & $6,561.2$ & $6,563.2$ & $6,557.3$ & 6.545 .7 & $6,575.4$ \\
\hline 34 & Commercial and industrial . & $1,134.9^{r}$ & $1,187.0$ & $1,187.4$ & $1,186.9$ & $1,186.0$ & $1,207.2$ & $1,251.0$ & $1,245.8$ & $1,247.0$ & $1,247.9$ & $1,243.7$ & $1,249.2$ \\
\hline 35 & Real estate & $3,564.1^{r}$ & $3,586.9$ & $3,575.1$ & $3,568.9$ & $3,572.9$ & $3,618.0$ & $3,781.0$ & $3,787.2$ & $3,785.7$ & $3,793.2$ & $3,775.9$ & $3,789.4$ \\
\hline 36 & Revolving home equity & 482.4 & 508.4 & 514.5 & 521.6 & 526.0 & 540.6 & 580.7 & 585.5 & 582.9 & 583.7 & 585.3 & 587.5 \\
\hline 37 & Other ............. & $3,081.7^{r}$ & $3,078.5$ & $3,060.7$ & $3,047,3$ & $3,046.9$ & $3,077.4$ & $3,200.3$ & $3,201.7$ & $3,202.8$ & $3,209.5$ & $3,190.6$ & $3,201.8$ \\
\hline 38 & Other residential & $1,519.8$ & $1,464.6$ & $1,438.9$ & $1,422.7$ & $1,418.6$ & $1,434.0$ & 1.511 .2 & $1,506.8$ & $1,511.5$ & $1,517.6$ & $1,495.6$ & $1,503.4$ \\
\hline 39 & Commercial. & $1,561.9^{r}$ & $1,613.9$ & $1,621.8$ & $1,624.5$ & $1,628.3$ & $1,643.4$ & $1,689.1$ & $1,694.9$ & $1,691.3$ & $1,691.9$ & $1,695.0$ & $1,698.4$ \\
\hline 40 & Consumer. & 796.3 & 822.8 & 826.9 & 833.0 & 843.7 & 854.0 & 865.9 & 876.7 & 868.4 & 872.0 & 878.3 & 882.1 \\
\hline 41 & Credit cards and related plans & 343.0 & 340.8 & 341.8 & 347.1 & 355.4 & 361.6 & 371.9 & 383.5 & 376.4 & 380.2 & 386.2 & 386.7 \\
\hline 42 & Other $\ldots \ldots \ldots \ldots \ldots \ldots$ & 453.3 & 482.0 & 485.2 & 485.8 & 488.3 & 492.3 & 494.0 & 493.2 & 492.1 & 491.9 & 492.1 & 495.4 \\
\hline 43 & Security ${ }^{4} \ldots$ & 139.7 & 191.5 & 181.8 & 184.8 & 196.9 & 240.5 & 226.6 & 210.3 & 211.5 & 207.4 & 210.1 & 213.7 \\
\hline 44 & Other loans and leases ........... & 439.7 & 431.1 & 429.3 & 435.1 & 432.2 & 457.2 & 460.2 & 441.2 & 450.5 & 436.7 & 437.7 & 441.0 \\
\hline 45 & Interbank loans $\ldots \ldots \ldots \ldots \ldots \ldots \ldots$ & 349.9 & 361.7 & 370.6 & 357.9 & 362.5 & 391.2 & 381.0 & 302.9 & 336.5 & 304.4 & 294.6 & 278.1 \\
\hline 46 & Cash assets ${ }^{5} \ldots \ldots \ldots \ldots$ & 249.7 & 247.3 & 237.4 & 236.1 & 231.9 & 303.4 & 443.0 & 588.6 & 528.4 & 622.6 & 568.0 & 599.5 \\
\hline 47 & Other assets $^{6}$ & 903.1 & 934.7 & 941.8 & 967.9 & 971.8 & $1,002.5$ & $1,037.9$ & $1,077.8$ & $1,037.4$ & $1,063.3$ & $1,086.6$ & $1,099.6$ \\
\hline 48 & Total assets ${ }^{7}$ & $9,493.1$ & $9,702.2$ & $9,676.1$ & $9,679.3$ & $9,695.2$ & $10,026.8$ & $10,553.3$ & $10,670.3$ & $10,581.0$ & $10,667.3$ & $10,606.2$ & $10,709.4$ \\
\hline & Liabilities & & & & & & & & & & & & \\
\hline 49 & Deposits . & $5,659.3$ & 5.725 .0 & $5,730.6$ & $5,735.7$ & $5,733.1$ & $5,955.3$ & $6,213.2$ & $6,252.2$ & $6,232.4$ & 6.272 .4 & $6,199.5$ & $6,269.3$ \\
\hline 50 & Transaction. & 601.2 & 592.5 & 586.1 & 588.6 & 573.6 & 612.0 & 645.6 & 693.2 & 650.5 & 655.2 & 687.9 & 752.8 \\
\hline 51 & Nontransaction . & $5,058.2$ & $5,132.5$ & $5,144.6$ & $5,147.2$ & $5,159.5$ & $5,343.3$ & $5,567.6$ & $5,559.0$ & $5,581.8$ & $5,617.2$ & $5,511.7$ & $5,516.6$ \\
\hline 52 & Large time. & $1,030.0$ & $1,014.5$ & $1,012.8$ & $1,019.4$ & $1,012.5$ & $1,074.8$ & $1,168.0$ & $1,113.6$ & $1,120.1$ & $1,117.4$ & $1,101.6$ & $1,117.4$ \\
\hline 53 & Other & $4,028.2$ & $4,118.1$ & $4,131.7$ & $4,127.8$ & $4,147.0$ & $4,268.5$ & $4,399.6$ & $4,445.5$ & $4,461.8$ & $4,499.8$ & $4,410.0$ & $4,399.1$ \\
\hline 54 & Borrowings . & $1,635.9$ & $1,721.4$ & $1,712.7$ & $1,712.7$ & $1,752.1$ & $1,827.6$ & $2,019.8$ & $1,996.8$ & $2,015.3$ & $2,040.5$ & $1,983.2$ & $1,974.5$ \\
\hline 55 & From banks in the U.S. & 398.9 & 413.2 & 411.6 & 399.2 & 404.5 & 395.2 & 399.0 & 367.2 & 377.4 & 372.5 & 365.1 & 361.9 \\
\hline 56 & From others $\ldots \ldots \ldots$ & $1,237.0$ & $1,308.2$ & $1,301.0$ & $1,313.5$ & $1,347.6$ & $1,432.4$ & $1,620.7$ & $1,629.6$ & $1,637.9$ & $1,668.0$ & $1,618.0$ & $1,612.6$ \\
\hline 57 & Net due to related foreign offices & 478.5 & 532.8 & 533.8 & 529.9 & 507.0 & $\begin{array}{r}1,+92.4 \\
495.2\end{array}$ & $\begin{array}{r}1.0<0.8 \\
508.9\end{array}$ & 554.2 & 534.6 & $\begin{array}{r}544.0 \\
54.0\end{array}$ & $\begin{array}{r}1,010.0 \\
558.7\end{array}$ & 568.3 \\
\hline 58 & Other liabilities ............. & 552.4 & 550.1 & 529.0 & 533.4 & 531.8 & 565.9 & 628.9 & 674.8 & 627.3 & 633.6 & 680.2 & 714.9 \\
\hline 59 & Total liabilities . & $8,326.1$ & $8,529.3$ & $8,506.1$ & $8,511.7$ & $8,524.0$ & $8,844.0$ & $9,370.8$ & $9,478.1$ & $9,409.5$ & $9,490.5$ & $9,421.6$ & $9,527.1$ \\
\hline 60 & Residual (assets less liabilities) ${ }^{8}$ & $1,167.0$ & $1,172.8$ & $1,170.0$ & $1,167.5$ & $1,171.2$ & $1,182.8$ & $1,182.5$ & $1,192.2$ & $1,171.5$ & $1,176.8$ & $1,184.6$ & $1,182.3$ \\
\hline
\end{tabular}

Footnotes appear on p. 21 
1.26 COMMERCIAL BANKS IN THE UNITED STATES Assets and Liabilities ${ }^{1}$ —Continued

C. Large domestically chartered commercial banks

Billions of dollars

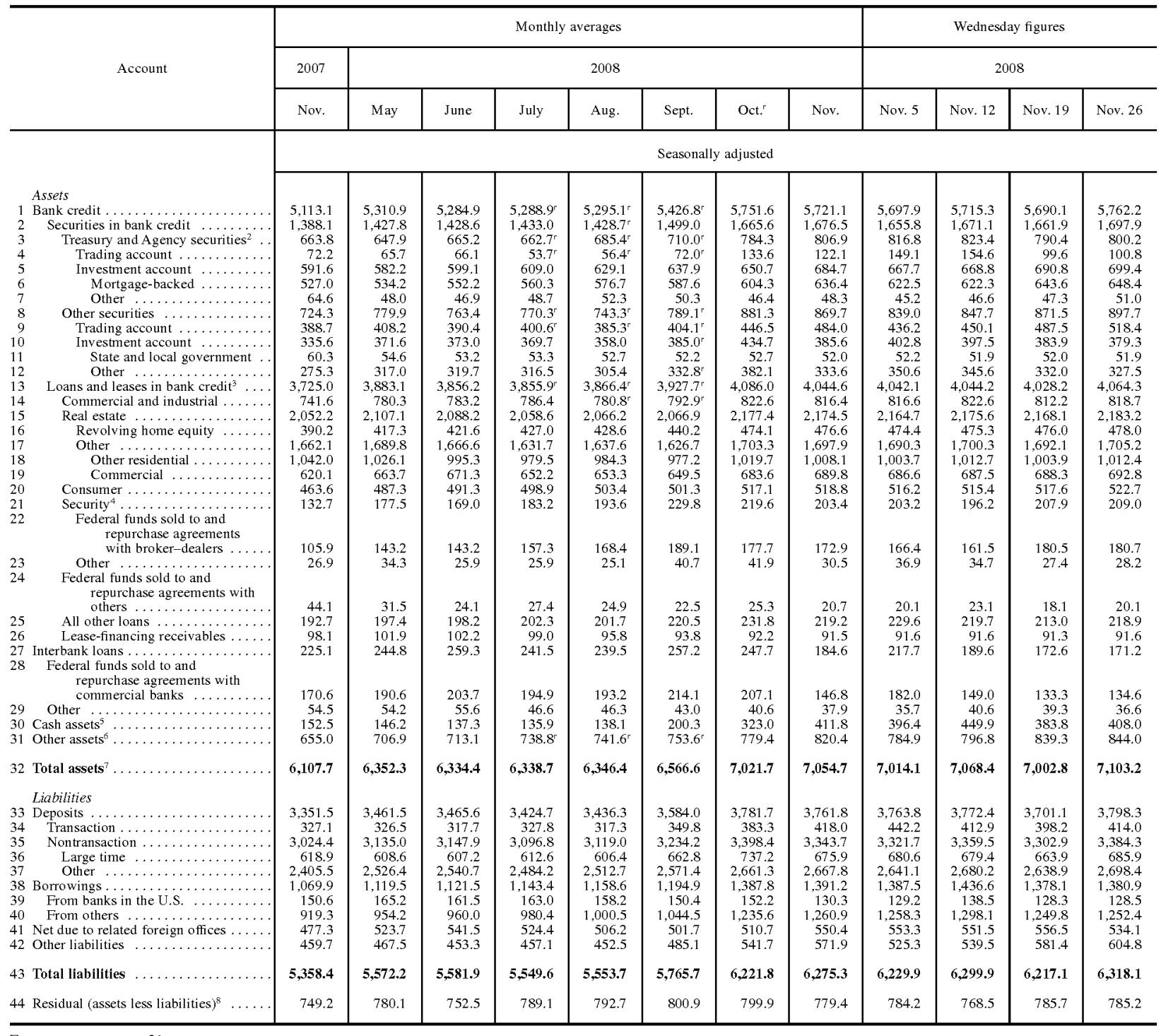

Footnotes appear on p. 21. 
18 Federal Reserve Bulletin Statistical Supplement $\square$ December 2008

1.26 COMMERCIAL BANKS IN THE UNITED STATES Assets and Liabilities 1 - Continued

C. Large domestically chartered commercial banks-Continued

Billions of dollars

\begin{tabular}{|c|c|c|c|c|c|c|c|c|c|c|c|c|c|}
\hline & \multirow{3}{*}{ Account } & \multicolumn{8}{|c|}{ Monthly averages } & \multirow{2}{*}{\multicolumn{4}{|c|}{$\begin{array}{c}\text { Wednesday figures } \\
2008\end{array}$}} \\
\hline & & \multirow{2}{*}{$\begin{array}{l}2007 \\
\text { Nov. }\end{array}$} & \multicolumn{7}{|c|}{2008} & & & & \\
\hline & & & May & June & July & Aug. & Sept. & Oct. & Nov. & Noy. 5 & Nov. 12 & Nov. 19 & Nov. 26 \\
\hline & & \multicolumn{12}{|c|}{ Not seasonally adjusted } \\
\hline \multicolumn{14}{|c|}{ Assets } \\
\hline 45 & Bank credit & $5,158.5$ & $5,279.5$ & $5,239.8$ & $5,238.8$ & $5,242.4^{r}$ & $5,428.8^{r}$ & $5,782.7$ & $5,776.2$ & $5,768.3$ & $5,762.5$ & $5,744.7$ & $5,814,0$ \\
\hline 46 & Securities in bank credit & $1,391.2$ & $1,438.5$ & $1,433.4$ & $1,430.1$ & $1,425.5$ & $1,491.4$ & $1,655.9$ & $1,684.7$ & $1,667.4$ & $1,669.6$ & $1,669.6$ & $1,711.0$ \\
\hline 47 & Treasury and Agency securities ${ }^{2}$ & 661.4 & 655.6 & 671.6 & 670.4 & $690.7^{r}$ & 705.8 & 774.0 & 806.1 & 824.2 & 818.8 & 790.5 & 797.6 \\
\hline 48 & Trading account $\ldots \ldots \ldots \ldots$ & 74.4 & 65.5 & 67.7 & 54.4 & $54.9^{r}$ & $68.7^{r}$ & 128.0 & 125.5 & 157.6 & 159.3 & 102.9 & 102.4 \\
\hline 49 & Investment account $\ldots \ldots \ldots$ & 587.0 & 590.1 & 603.8 & 616.0 & 635.8 & 637.1 & 645.9 & 680.6 & 666.7 & 659.5 & 687.6 & 695.2 \\
\hline 50 & Mortgage-backed & 520.4 & 542.0 & 556.0 & 567.5 & 583.4 & 586.0 & 599.0 & 630.8 & 619.5 & 611.3 & 638.4 & 643.1 \\
\hline 51 & Other ......... & 66.6 & 48.0 & 47.8 & 48.5 & 52.4 & 51.1 & 46.9 & 49.7 & 47.2 & 48.3 & 49.1 & 52.1 \\
\hline 52 & Other securities & 729.8 & 782.9 & 761.9 & $759.7^{\circ}$ & $734.7^{r}$ & $785.7^{\mathrm{r}}$ & 881.9 & 878.6 & 843.2 & 850.7 & 879.1 & 913.4 \\
\hline 53 & Trading account & 394.3 & 411.7 & 391.6 & 392.7 & $379.0^{r}$ & $399.8^{r}$ & 447.6 & 492.0 & 439.1 & 452.4 & 495.0 & 533.6 \\
\hline 54 & Investment account & 335.6 & 371.2 & 370.3 & 367.0 & 355.8 & $385.9^{r}$ & 434.3 & 386.5 & 404.1 & 398.3 & 384.1 & 379.8 \\
\hline 55 & State and local government & 60.8 & 54.9 & 53.1 & 52.7 & 52.1 & 52.2 & 52.8 & 52.5 & 52.6 & 52.5 & 52.8 & 52.2 \\
\hline 56 & Other $\ldots \ldots \ldots \ldots \ldots$ & 274.8 & 316.3 & 317.2 & 314.3 & 303.6 & 333.6 & 381.5 & 334.0 & 351.5 & 345.8 & 331.3 & 327.6 \\
\hline 57 & Loans and leases in bank credit ${ }^{3}$ & $3,767.3$ & $3,841.0$ & $3,806.4$ & $3,808.7$ & $3,816.9^{r}$ & $3,937.4^{r}$ & $4,126.9$ & $4,091.6$ & $4,100.9$ & $4,093.0$ & $4,075.0$ & $4,103.0$ \\
\hline 58 & Commercial and industrial ... & 746.2 & 778.8 & 777.6 & 777.5 & $775.4^{r}$ & $792.0^{\mathrm{r}}$ & 828.0 & 821.9 & 822.9 & 824.3 & 820.3 & 825.0 \\
\hline 59 & Real estate $\ldots \ldots \ldots \ldots$ & $2,091.3$ & $2,069.3$ & $2,048.8$ & $2,039.3$ & $2,035.1$ & $2,067.0$ & $2,216.3$ & $2,218.2$ & $2,218.1$ & $2,224.4$ & $2,208.6$ & $2,219.6$ \\
\hline 60 & Revolving home equity & 394.1 & 413.7 & 418.3 & 424.3 & 427.6 & 440.1 & 478.2 & 481.6 & 479.7 & 480.3 & 481.5 & 483.2 \\
\hline 61 & Other $\ldots \ldots \ldots \ldots \ldots$ & $1,697.2$ & $1,655.7$ & $1,630.5$ & $1,615.0$ & $1,607.4$ & $1,626.8$ & $1,738.1$ & $1,736.6$ & $1,738.4$ & $1,744.0$ & $1,727.1$ & $1,736.4$ \\
\hline 62 & Other residential & $1,067.6$ & $1,005.2$ & 977.8 & 963.3 & 955.9 & 968.9 & $1,039.6$ & $1,035.5$ & $1,038.9$ & $1,044.0$ & $1,026.6$ & $1,033.3$ \\
\hline 63 & Commercial .... & 629.6 & 650.5 & 652.7 & 651.7 & 651.5 & 658.0 & 698.4 & 701.1 & 699.5 & 700.0 & 700.5 & 703.2 \\
\hline 64 & Consumer....... & 462.8 & 486.5 & 487.7 & 491.9 & 497.8 & 503.6 & 515.4 & 517.7 & 514.7 & 515.4 & 517.3 & 520.7 \\
\hline 65 & Credit cards and related plans & 131.6 & 131.1 & 131.2 & 134.5 & 137.9 & 142.5 & 155.9 & 158.5 & 156.0 & 156.8 & 159.2 & 160.1 \\
\hline 66 & Other & 331.2 & 355.4 & 356.5 & 357.4 & 359.9 & 361.1 & 359.5 & 359.2 & 358.7 & 358.6 & 358.2 & 360.6 \\
\hline 67 & Security ${ }^{4}$. & 130.7 & 180.5 & 170.7 & 173.6 & 185.7 & 229.0 & 215.6 & 200.4 & 201.2 & 197.5 & 200.1 & 204.5 \\
\hline \multirow[t]{2}{*}{68} & $\begin{array}{l}\text { Federal funds sold to and } \\
\text { repurchase agreements }\end{array}$ & & & & & & & & & & & & \\
\hline & with broker-dealers & 103.7 & 145.5 & 144.7 & 148.4 & 161.3 & 189.2 & 175.0 & 169.8 & 164.8 & 162.1 & 173.3 & 175.4 \\
\hline 69 & Other $\ldots \ldots \ldots \ldots$. & 27.0 & 35.0 & 25.9 & 25.2 & 24.4 & 39.9 & 40.6 & 30.6 & 36.4 & 35.4 & 26.8 & 29.0 \\
\hline \multirow[t]{2}{*}{70} & $\begin{array}{l}\text { Federal funds sold to and } \\
\text { repurchase agreements }\end{array}$ & & & & & & & & & & & & \\
\hline & with others .......... & 46.0 & 28.1 & 23.7 & 25.2 & 26.1 & 26.3 & 27.4 & 21.5 & 21.5 & 21.1 & 20.0 & 22.2 \\
\hline 71 & All other loans $\ldots \ldots \ldots \ldots$. & 190.7 & 197.6 & 197.8 & 202.0 & 200.9 & 224.3 & 230.4 & 219.1 & 229.5 & 217.5 & 216.0 & 218.0 \\
\hline 72 & Lease-financing receivables & 99.5 & 100.1 & 100.1 & 99.1 & 96.0 & 95.2 & 93.8 & 92.9 & 93.1 & 92.9 & 92.8 & 93.0 \\
\hline 73 & Interbank loans . ............ & 230.1 & 239.5 & 249.1 & 235.5 & 237.8 & 259.8 & 249.1 & 188.4 & 215.0 & 191.7 & 179.6 & 179.7 \\
\hline 74 & $\begin{array}{l}\text { Federal funds sold to and } \\
\text { repurchase agreements }\end{array}$ & & & & & & & & & & & & \\
\hline & with commercial banks & 173.7 & 187.0 & 195.1 & 189.8 & 192.0 & 217.2 & 207.9 & 149.1 & 177.3 & 149.6 & 139.4 & 142.0 \\
\hline & Other $\ldots \ldots \ldots \ldots \ldots$ & 56.4 & 52.5 & 54.0 & 45.7 & 45.7 & 42.6 & 41.2 & 39.2 & 37.7 & 42.0 & 40.2 & 37.7 \\
\hline 76 & Cash assets & 156.6 & 143.7 & 133.7 & 131.6 & 127.3 & 197.1 & 321.3 & 422.0 & 385.8 & 464.8 & 404.4 & 414.8 \\
\hline 77 & Other assets ${ }^{5} \ldots$. & 658.2 & 701.2 & 702.9 & 733.9 & $735.1^{r}$ & $761.4^{r}$ & 791.1 & 824.3 & 790.2 & 806.3 & 840.3 & 848.8 \\
\hline 78 & Total assets ${ }^{7}$ & $6,165.5$ & $6,307.5$ & $6,265.6$ & $6,272.9$ & $6,274.6$ & $6, \mathbf{5 7 5 . 5}$ & $7,064.3$ & $7,128.4$ & $7,076.6$ & $7,142.5$ & $7,086.9$ & $\mathbf{7 , 1 7 7 . 1}$ \\
\hline & Liabilities & & & & & & & & & & & & \\
\hline 79 & Deposits. & $3,395.5$ & $3,405.6$ & $3,397.8$ & $3,394.1$ & $3,380.4$ & $3,583.0$ & $3,816.9$ & $3,818.4$ & $3,813.3$ & $3,832.9$ & $3,774.6$ & $3,829.0$ \\
\hline 80 & Transaction & 329.8 & 323.2 & 315.6 & 317.2 & 306.4 & 345.5 & 375.8 & 421.5 & 392.0 & 392.2 & 421.3 & 466.5 \\
\hline 81 & Nontransaction . & $3,065.7$ & $3,082.4$ & $3,082.3$ & $3,076.9$ & $3,073.9$ & $3,237.5$ & $3,441.1$ & $3,396.9$ & $3,421.3$ & $3,440.7$ & $3,353.3$ & $3,362.5$ \\
\hline 82 & Large time $\ldots \ldots \ldots \ldots$ & 624.4 & 600.7 & 597.4 & 603.2 & 595.6 & 656.6 & 746.2 & 685.0 & 694.9 & 690.1 & 673.3 & 686.5 \\
\hline 83 & Other ...... & $2,441.3$ & $2,481.7$ & $2,484.9$ & $2,473.7$ & $2,478.3$ & $2,580.9$ & $2,694.9$ & $2,711.9$ & $2,726.4$ & $2,750.6$ & $2,680.0$ & $2,676.0$ \\
\hline 84 & Borrowings ..... & $1,069.0$ & $1,128.2$ & $1,118.5$ & $1,124.7$ & $1,161.7$ & $1,231.0$ & $1,407.2$ & $1,391.7$ & $1,409.8$ & $1,436.7$ & $1,378.5$ & $1,375.5$ \\
\hline 85 & From banks in the U.S. & 151.2 & 166.1 & 159.1 & 155.4 & 155.9 & 150.6 & 151.0 & 130.6 & 131.0 & 140.3 & 127.2 & 126.7 \\
\hline 86 & From others & 917.8 & 962.0 & 959.4 & 969.3 & $1,005.8$ & $1,080.5$ & $1,256.2$ & $1,261.1$ & $1,278.7$ & $1,296.4$ & $1,251.4$ & $1,248.9$ \\
\hline 87 & Net due to related foreign offices. & 474.8 & 528.2 & 529.8 & 524.8 & 504.1 & 492.3 & 507.3 & 548.8 & 531.9 & 540.1 & 552.6 & 560.5 \\
\hline 88 & Other liabilities $\ldots . \ldots \ldots \ldots$. & 474.9 & 469.7 & 448.4 & 454.0 & 452.1 & 484.6 & 548.1 & 591.8 & 546.0 & 553.3 & 599.3 & 633.1 \\
\hline 89 & Total liabilities & $5,414.2$ & $\mathbf{5 , 5 3 1 . 7}$ & $5,494.5$ & $5,497.5$ & $5,498.3$ & $5,790.9$ & $6,279.5$ & $6,350.7$ & $6,301.0$ & $6,363.0$ & $6,305.0$ & $6,398.1$ \\
\hline 90 & Residual (assets less liabilities) ${ }^{8}$ & 751.3 & 775.7 & 771.1 & 775.4 & 776.3 & 784.6 & 784.8 & 777.7 & 775.6 & 779.6 & 781.9 & 779.0 \\
\hline
\end{tabular}

Footnotes appear on p. 21. 
1.26 COMMERCIAL BANKS IN THE UNITED STATES Assets and Liabilities ${ }^{1}$ —Continued

D. Small domestically chartered commercial banks

Billions of dollars

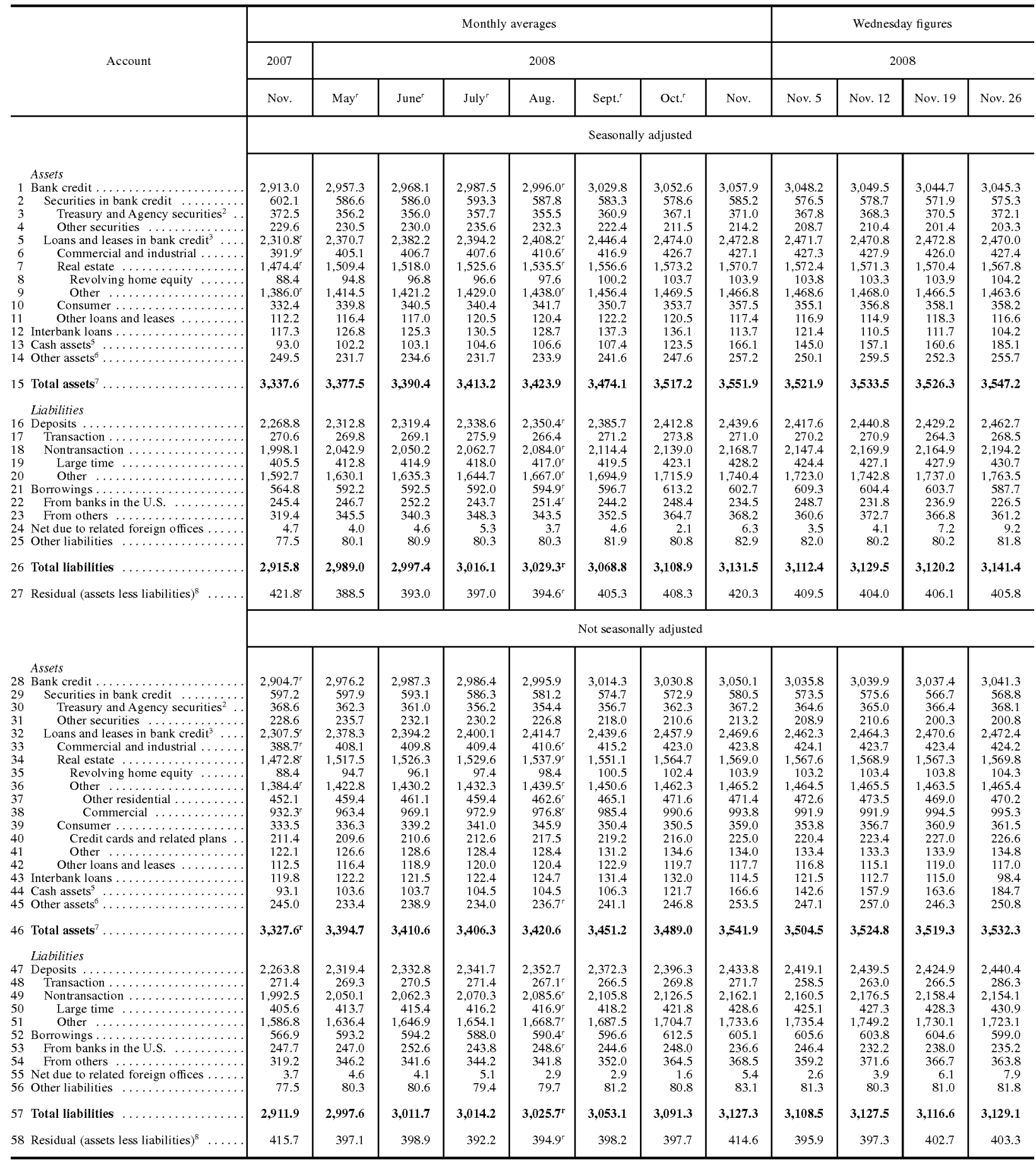

Footnotes appear on p. 21. 
1.26 COMMERCIAL BANKS IN THE UNITED STATES Assets and Liabilities ${ }^{1}$ C Continued E. Foreign-related institutions

Billions of dollars

\begin{tabular}{|c|c|c|c|c|c|c|c|c|c|c|c|c|c|}
\hline \multirow{3}{*}{\multicolumn{2}{|c|}{ Account }} & \multicolumn{8}{|c|}{ Monthly averages } & \multirow{2}{*}{\multicolumn{4}{|c|}{$\frac{\text { Wednesday figures }}{2008}$}} \\
\hline & & \multirow{2}{*}{$\begin{array}{l}2007 \\
\text { Nov. }\end{array}$} & \multicolumn{7}{|c|}{2008} & & & & \\
\hline & & & May & June & July & Aug. & Sept.' & Oct. ${ }^{r}$ & Nov. & Noy. 5 & Nov. 12 & Nov. 19 & Nov. 26 \\
\hline & & \multicolumn{12}{|c|}{ Seasonally adjusted } \\
\hline & Assets & & & & & & & & & & & & \\
\hline 1 & Bank credit..$\ldots \ldots$. & $1,154.2$ & $1,135.1^{\mathrm{r}}$ & $1,121.5^{r}$ & $1,122.6^{r}$ & $1,124.1^{\mathrm{r}}$ & $1,118.7$ & $1,152.9$ & $1,118.9$ & $1,120.2$ & $1,141.4$ & $1,124.3$ & $1,096.6$ \\
\hline 2 & Securities in bank credit & 474.2 & 466.8 & $457.2^{r}$ & $468.0^{r}$ & $464.6^{r}$ & 454.8 & 475.3 & 464.1 & 460.3 & 478.3 & 473.6 & 447.7 \\
\hline 3 & Treasury and Agency securities ${ }^{2}$ & 92.7 & 91.8 & 91.6 & 93.7 & 86.8 & 83.0 & 75.6 & 83.4 & 86.3 & 87.0 & 80.9 & 80.1 \\
\hline 4 & Other securities $\ldots \ldots \ldots \ldots$. & 381.5 & 375.0 & $365.7^{\mathrm{r}}$ & $374.3^{r}$ & $377.8^{\mathrm{r}}$ & 371.8 & 399.6 & 380.7 & 374.0 & 391.3 & 392.7 & 367.6 \\
\hline 5 & Loans and leases in bank credit ${ }^{3}$ & 680.0 & $668.3^{r}$ & $664.3^{r}$ & 654.5 & $659.6^{r}$ & 663.9 & 677.7 & 654.8 & 659.9 & 663.1 & 650.7 & 648.9 \\
\hline 6 & Commercial and industrial ... & 275.1 & $310.9^{r}$ & $313.2^{r}$ & $314.4^{r}$ & $317.0^{\mathrm{r}}$ & 326.3 & 350.8 & 352.9 & 352.7 & 353.6 & 351.0 & 353.5 \\
\hline 7 & Real estate...$\ldots \ldots \ldots$. & 35.7 & $40.8^{r}$ & 42.1 & 42.8 & 44.1 & 43.0 & 40.8 & 39.1 & 38.8 & 39.0 & 38.9 & 39.4 \\
\hline 8 & Security ${ }^{4}$. & 140.6 & 103.8 & 100.4 & 100.3 & 100.7 & 89.7 & 72.0 & 56.6 & 60.1 & 58.1 & 58.7 & 53.1 \\
\hline 9 & Other loans and leases & 228.6 & 212.8 & $208.6^{r}$ & $197.1^{r}$ & $197.7^{r}$ & 204.9 & 214.1 & 206.2 & 208.3 & 212.3 & 202.1 & 203.0 \\
\hline 10 & Interbank loans $\ldots \ldots \ldots$. & 79.0 & $75.0^{r}$ & $68.5^{r}$ & $65.7^{r}$ & $66.0^{r}$ & 68.1 & 60.9 & 46.5 & 42.9 & 43.7 & 50.1 & 49.0 \\
\hline 11 & Cash assets ${ }^{5} . .$. & 56.7 & 58.1 & 59.6 & 56.1 & 53.2 & 60.8 & 130.1 & 273.7 & 243.3 & 256.3 & 314.1 & 273.2 \\
\hline 12 & Other assets ${ }^{6}$ & 49.0 & 49.3 & 56.3 & 48.5 & 43.0 & 46.7 & 60.6 & 54.3 & 60.0 & 52.6 & 54.6 & 52.0 \\
\hline 13 & Total assets $^{7} \ldots$ & $1, \mathbf{3 3 8} .9$ & $1,317.4^{r}$ & $1,305.8^{r}$ & $1,292.9$ & $1,286.3$ & $1,294.2$ & $1,404.4$ & $1,493.4$ & $1,466.4$ & $1,493.9$ & $1,543.0$ & $1,470.7$ \\
\hline & Liabilities & & & & & & & & & & & & \\
\hline 14 & Deposits & $1,017.5$ & $1,112.8$ & $1,124.6$ & $1,120.9$ & $1,127.6^{r}$ & $1,102.9$ & 930.6 & 862.2 & 903.0 & 864.3 & 860.9 & 840.8 \\
\hline 15 & Transaction ... & 13.1 & 17.0 & 16.8 & 17.2 & 16.5 & 19.1 & 22.3 & 18.3 & 18.5 & 18.3 & 19.3 & 17.6 \\
\hline 16 & Nontransaction & $1,004.4$ & $1,095.8$ & $1,107.9$ & $1,103.7$ & $1,111.0$ & $1,083.8$ & 908.3 & 843.8 & 884.5 & 846.0 & 841.6 & 823.1 \\
\hline 17 & Borrowings ...... & 586.7 & 607.4 & 602.9 & 605.1 & 603.6 & 607.0 & 618.8 & 607.4 & 592.7 & 614.9 & 627.9 & 596.5 \\
\hline 18 & From banks in the U.S. & 60.7 & 71.9 & 69.7 & 72.9 & 67.4 & 84.0 & 57.9 & 39.8 & 35.8 & 39.2 & 36.1 & 46.7 \\
\hline 19 & From others $\ldots \ldots \ldots$. & 526.0 & 535.5 & 533.2 & 532.2 & 536.2 & 523.0 & 561.0 & 567.6 & 556.9 & 575.7 & 591.7 & 549.8 \\
\hline 20 & Net due to related foreign offices & -396.0 & -551.2 & -564.6 & -576.7 & -602.0 & -568.1 & -332.6 & -167.4 & -219.1 & -167.7 & -133.6 & -164.9 \\
\hline 21 & Other liabilities $\ldots \ldots \ldots \ldots$. & 128.7 & 145.8 & 140.3 & 137.2 & 140.5 & 148.1 & 183.4 & 185.8 & 180.6 & 179.8 & 191.3 & 188.7 \\
\hline 22 & Total liabilities & $1,336.9$ & $1,314.7$ & $1,303.1$ & $1,286.5$ & $1,269.6$ & $1,289.9$ & $1,400.3$ & $1,488.0$ & $1,457.3$ & $1,491.2$ & $1,546.5$ & $1,461.1$ \\
\hline \multirow[t]{3}{*}{23} & Residual (assets less liabilities) ${ }^{8}$ & 2.1 & 2.7 & $2.7^{r}$ & $6.4^{r}$ & 16.7 & 4.4 & 4.1 & 5.4 & 9.1 & 2.7 & -3.5 & 9.6 \\
\hline & & \multicolumn{12}{|c|}{ Not seasonally adjusted } \\
\hline & Assets & & & & & & & & & & & & \\
\hline 24 & Bank credit ..... & $1,162.7$ & $1,130.0^{r}$ & $1,113.7^{r}$ & $1,103.9^{r}$ & $1,110.5^{r}$ & $1,110.5$ & $1,150.8$ & $1,126.8$ & $1,127.0$ & $1,142.5$ & $1,128.7$ & $1,112.4$ \\
\hline 25 & Securities in bank credit & 480.3 & 470.0 & $458.5^{r}$ & $460.0^{r}$ & $458.9^{r}$ & 450.2 & 473.3 & 470.2 & 466.9 & 482.1 & 477.3 & 456.3 \\
\hline 26 & Treasury and Agency securities ${ }^{2}$ & 93.1 & 92.2 & 90.9 & 92.0 & 87.8 & 83.8 & 76.2 & 83.6 & 86.5 & 87.3 & 80.7 & 80.5 \\
\hline 27 & Trading account $\ldots \ldots \ldots \ldots$ & 26.6 & 30.1 & 28.7 & 29.3 & 29.0 & 28.1 & 27.2 & 26.8 & 30.5 & 30.0 & 25.8 & 23.5 \\
\hline 28 & Investment account & 66.5 & 62.1 & 62.2 & 62.6 & 58.8 & 55.6 & 49.1 & 56.8 & 56.1 & 57.3 & 54.9 & 57.1 \\
\hline 29 & Other securities ..... & 387.2 & 377.8 & $367.6^{r}$ & $368.0^{r}$ & $371.1^{r}$ & 366.5 & 397.1 & 386.6 & 380.4 & 394.9 & 396.7 & 375.8 \\
\hline 30 & Trading account . & 228.8 & 235.0 & $221.5^{r}$ & $219.3^{r}$ & $227.1^{\mathrm{r}}$ & 221.8 & 236.6 & 240.4 & 227.6 & 244.6 & 251.9 & 231.9 \\
\hline 31 & Investment account & 158.4 & 142.8 & 146.1 & 148.7 & 144.0 & 144.7 & 160.5 & 146.2 & 152.9 & 150.2 & 144.7 & 143.9 \\
\hline 32 & Loans and leases in bank credit ${ }^{3}$ & 682.4 & $660.0^{r}$ & $655.2^{r}$ & $643.9^{r}$ & $651.6^{r}$ & 660.2 & 677.5 & 656.6 & 660.1 & 660.4 & 651.4 & 656.1 \\
\hline 33 & Commercial and industrial ... & 274.8 & $307.5^{r}$ & $309.8^{r}$ & $310.5^{r}$ & $315.2^{\mathrm{r}}$ & 326.3 & 349.6 & 353.2 & 351.6 & 351.2 & 351.9 & 356.2 \\
\hline 34 & Real estate $\ldots \ldots \ldots \ldots$ & 36.5 & 41.1 & 41.7 & 42.2 & 42.4 & 42.8 & 41.8 & 39.9 & 40.0 & 39.9 & 39.5 & 40.0 \\
\hline 35 & Security ${ }^{4}$. & 144.4 & 102.4 & 99.1 & 97.0 & 98.0 & 86.8 & 72.0 & 58.5 & 61.0 & 60.0 & 59.4 & 56.7 \\
\hline 36 & Other loans and leases ...... & 226.7 & 209.0 & $204.6^{r}$ & $194.2^{r}$ & $196.0^{\mathrm{r}}$ & 204.3 & 214.1 & 205.1 & 207.5 & 209.3 & 200.6 & 203.2 \\
\hline 37 & Interbank loans $\ldots \ldots \ldots \ldots \ldots \ldots$ & 83.8 & $72.3^{r}$ & $65.2^{r}$ & $64.2^{r}$ & $64.4^{r}$ & 69.4 & 62.6 & 48.7 & 45.1 & 45.5 & 50.5 & 52.7 \\
\hline 38 & Cash assets ${ }^{5}$.. & 57.7 & 56.8 & 58.8 & 56.3 & 54.0 & 62.7 & 132.2 & 278.9 & 247.9 & 265.3 & 318.9 & 278.6 \\
\hline 39 & Other assets ${ }^{6}$ & 47.3 & 50.4 & 57.4 & 48.2 & 43.0 & 48.1 & 59.0 & 52.6 & 57.7 & 51.9 & 50.2 & 51.6 \\
\hline 40 & Total assets ${ }^{7}$ & $1,351.6$ & $1,309.5$ & $1,295.0^{r}$ & $1,272.5$ & $1,271.8$ & $1,290.6$ & $1,404.6$ & $1,506.9$ & $1,477.7$ & $1,505.1$ & $1,548.3$ & $1,495.3$ \\
\hline & Liabilities & & & & & & & & & & & & \\
\hline 41 & Deposits . & $1,017.0$ & $1,137.0$ & $1,133.9$ & $1,095.2$ & $1,111.1^{r}$ & $1,097.0$ & 931.9 & 865.2 & 903.0 & 872.1 & 862.9 & 845.6 \\
\hline 42 & Transaction . & 12.8 & 16.8 & 16.5 & 16.8 & 16.3 & 19.0 & 21.8 & 17.9 & 17.7 & 17.9 & 18.4 & 17.9 \\
\hline 43 & Nontransaction & $1,004.2$ & $1,120.1$ & $1,117.3$ & $1,078.4$ & $1,094.7$ & $1,078.0$ & 910.1 & 847.3 & 885.3 & 854.2 & 844.5 & 827.8 \\
\hline 44 & Borrowings.... & 585.6 & 617.3 & 605.6 & 594.3 & 591.0 & 586.5 & 597.7 & 604.1 & 589.0 & 607.4 & 615.6 & 601.6 \\
\hline 45 & From banks in the U.S. & 63.3 & 67.8 & 67.6 & 68.1 & 65.4 & 82.7 & 55.3 & 40.8 & 35.2 & 38.9 & 39.9 & 46.4 \\
\hline 46 & From others & 522.3 & 549.5 & 538.0 & 526.3 & 525.6 & 503.8 & 542.3 & 563.3 & 553.8 & 568.6 & 575.7 & 555.2 \\
\hline 47 & Net due to related foreign offices & -383.4 & -597.3 & -586.1 & -553.2 & -573.3 & -543.2 & -313.8 & -155.2 & -204.8 & -160.7 & -125.5 & -147.4 \\
\hline 48 & Other liabilities $\quad \ldots . \ldots \ldots \ldots \ldots$ & 130.4 & 149.2 & 138.3 & 132.7 & $139.6^{r}$ & 146.8 & 182.9 & 187.8 & 184.5 & 180.2 & 189.2 & 192.5 \\
\hline 49 & Total liabilities & $1,349.6$ & $1,306.2$ & $1,291.6$ & $1,269.1^{\mathrm{r}}$ & $1,268.4$ & $1,287.2$ & $1,398.7$ & $1,501.9$ & $1,471.7$ & $1,499.1$ & $1,542.2$ & $1,492.3$ \\
\hline 50 & Residual (assets less liabilities) ${ }^{8}$ & 2.0 & 3.3 & 3.4 & 3.4 & $3.3^{r}$ & 3.4 & 5.9 & 4.9 & 6.0 & 6.0 & 6.1 & 3.1 \\
\hline
\end{tabular}

Footnotes appear on p. 21. 
1.26 COMMERCIAL BANKS IN THE UNITED STATES Assets and Liabilities ${ }^{1}$ —Continued

\section{F. Memo items}

Billions of dollars

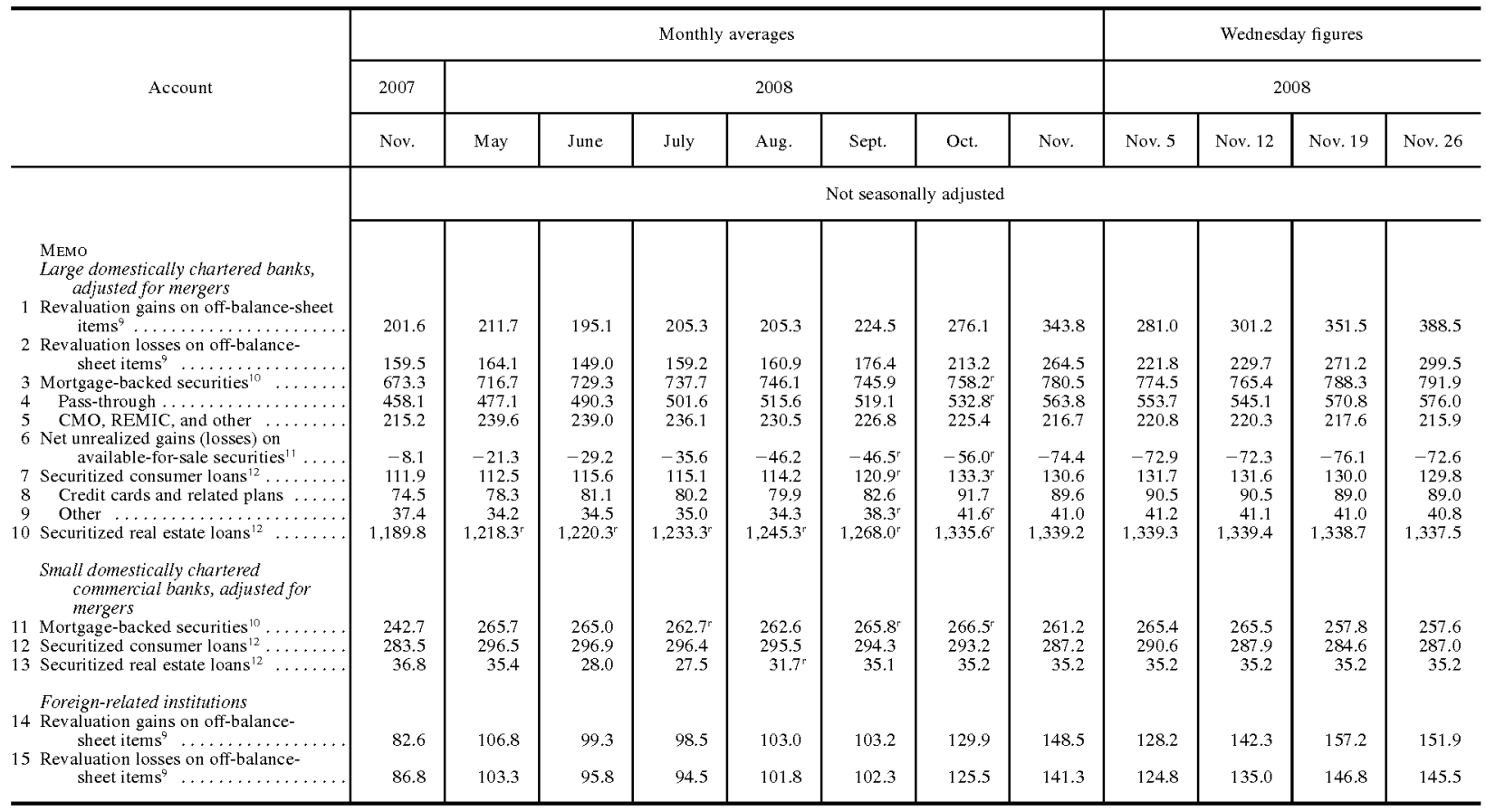

NoTEs: Tables $1.26,1.27$, and 1.28 have been revised to reflect changes in the Board's H. 8 statistical release, "Assets and Liabilities of Commercial Banks in the United States," which is available at www.federalreserve.gov/releases. Table 1.27, "Assets and Liabilities of Large Weekly Reporting Commercial Banks," and table 1.28, "Large Weekly Reporting U.S. Branches and Agencies of Foreign Banks," are no longer being published in the Statistical Supplement. Instead, abbreviated balance sheets for both large and small domestically chartered banks have been included in table 1.26, parts $C$ and D. Data are both mergeradjusted and break-adjusted. In addition, data from large weekly reporting U.S. branches and agencies of foreign banks have been replaced by balance sheet estimates of all foreign-related institutions and are included in table 1.26, part $E$. These data are break-adjusted.

1. Covers the following types of institutions in the fifty states and the District of Columbia: domestically chartered commercial banks that submit a weekly report of condition (large domestic); other domestically chartered commercial banks (small domestic); branches and agencies of foreign banks, and Edge Act and Agreement corporations (foreign-related institutions). Excludes international banking facilities. Data are Wednesday values or pro tata ayerages of Wednesday values. Large domestic banks constitute a universe; data for small domestic banks and foreign-related institutions are estimates based on weekly samples and on quarter-end condition reports. Data are adjusted for breaks caused by reclassifications of assets and liabilities.

The data for large and small domestic banks presented on pp. 17-19 are adjusted to remove the estimated effects of mergers between these two groups. The adjustment for mergets changes past levels to make them comparable with current levels. Estimated quantities of balance sheet items acquired in mergers are removed from past data for the bank group that contained the acquired bank and put into past data for the groun containing the acquiring bank. Balance sheet data for acquired banks are obtained from Call Reports, and a ratio procedure is used to adjust past levels.

2. Treasury securities are liabilities of the U.S. Treasury. Agency securities are liabilities of U.S. government agencies and U.S. government-sponsored enterprises.

3. Excludes federal funds sold to, reverse RPs with, and loans made to commercial banks in the United States, all of which are included in "Interbank loans."

4. Consists of reverse RPs with brokers and dealers and loans to purchase and carry securities.

5. Includes vault cash, cash items in process of collection, balances due from depository institutions, and balances due from Federal Reserve Banks.

6. Excludes the due-from position with related foreign offices, which is included in "Net due to related foreign offices."

7. Excludes unearned income, reserves for losses on loans and leases, and reserves for transfer risk. Loans are reported gross of these items.

8. This balancing item is not intended as a measure of equity capital for use in capital adequacy analysis. On a seasonally adjusted basis, this item reflects any differences in the seasonal patterns estimated for total assets and total liabilities.

9. Fair value of derivative contracts (interest rate, foreign exchange rate, other commodity and equity contracts) in a gain/loss position, as determined under FASB Interpretation No. 39 The fair market value of derivative contracts in a gain position is included in "Othe securities trading account." The fair value of derivative contracts in a loss nosition is included in "Other liabilities."

10. Includes mortgage-backed securities issued by U.S. government agencies, U.S. government-sponsored enterprises, and private entities.

11. Difference between fair value and historical cost for securities classified as availablefor-sale under FASB Statement No. 115. Data are reported net of tax effects. Data shown are

12. Total amount outstanding. 
1.32 COMMERCIAL PAPER OUTSTANDING

Millions of dollars, seasonally adjusted, end of period

\begin{tabular}{|c|c|c|c|c|c|c|c|c|c|c|c|}
\hline \multirow{2}{*}{ Item } & \multicolumn{5}{|c|}{ Year ending December } & \multicolumn{6}{|c|}{2008} \\
\hline & 2003 & 2004 & 2005 & 2006 & 2007 & Mar. & Apr. & May & June & July & Aug. \\
\hline 1 All issuers & $1,284,153$ & $1,403,929$ & $1,662,157$ & $1,983,118$ & $1,780,685$ & $1,821,489$ & $1,757,975$ & $1,748,960$ & $1,740,990$ & $1,732,714$ & $1,777,235$ \\
\hline $\begin{array}{l}2 \text { Financial companies' .... } \\
3 \text { Nonfinancial companies }\end{array}$ & $\begin{array}{l}519,785 \\
112,292\end{array}$ & $\begin{array}{l}589,499 \\
129,902\end{array}$ & $\begin{array}{l}663,951 \\
142,363\end{array}$ & $\begin{array}{l}730,735 \\
167,075\end{array}$ & $\begin{array}{l}816,693 \\
162,720\end{array}$ & $\begin{array}{l}835,350 \\
173,591\end{array}$ & $\begin{array}{l}802,401 \\
186,154\end{array}$ & $\begin{array}{l}810,988 \\
181,125\end{array}$ & $\begin{array}{l}817,619 \\
165,069\end{array}$ & $\begin{array}{l}808,065 \\
168,861\end{array}$ & $\begin{array}{l}832,343 \\
195,466\end{array}$ \\
\hline
\end{tabular}

1. Institutions engaged primarily in commercial, savings, and mortgage banking; sales, personal, and mortgage financing; factoring, finance leasing, and other business lending; insurance underwriting; and other investment activities.

2. Includes public utilities and firms engaged primarily in such activities as communications, construction, manufacturing, mining, wholesale and retail trade, transportation, and services.

1.33 PRIME RATE CHARGED BY BANKS Short-Term Business Loans ${ }^{1}$

Percent per year

\begin{tabular}{|c|c|c|c|c|c|c|c|}
\hline Date of change & Rate & Period & $\begin{array}{c}\text { Average } \\
\text { rate }\end{array}$ & Period & $\begin{array}{c}\text { Average } \\
\text { rate }\end{array}$ & Period & $\begin{array}{c}\text { Average } \\
\text { rate }\end{array}$ \\
\hline 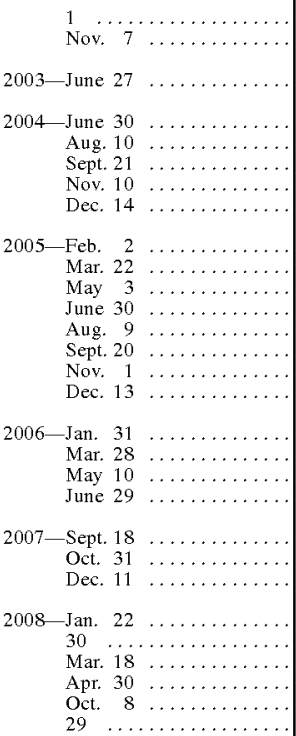 & $\begin{array}{l}4.75 \\
4.25 \\
\\
4.00 \\
\\
4.25 \\
4.50 \\
4.75 \\
5.00 \\
5.25 \\
\\
5.50 \\
5.75 \\
6.00 \\
6.25 \\
6.50 \\
6.75 \\
7.00 \\
7.25 \\
7.50 \\
7.75 \\
8.00 \\
8.25 \\
7.75 \\
7.50 \\
7.25 \\
\\
6.50 \\
6.00 \\
5.25 \\
5.00 \\
4.50 \\
4.00\end{array}$ & 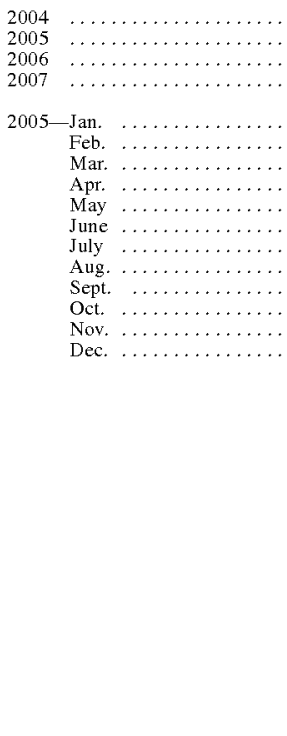 & $\begin{array}{l}4.34 \\
6.19 \\
7.96 \\
8.05 \\
\\
5.25 \\
5.49 \\
5.58 \\
5.75 \\
5.98 \\
6.01 \\
6.25 \\
6.44 \\
6.59 \\
6.75 \\
7.00 \\
7.15\end{array}$ & 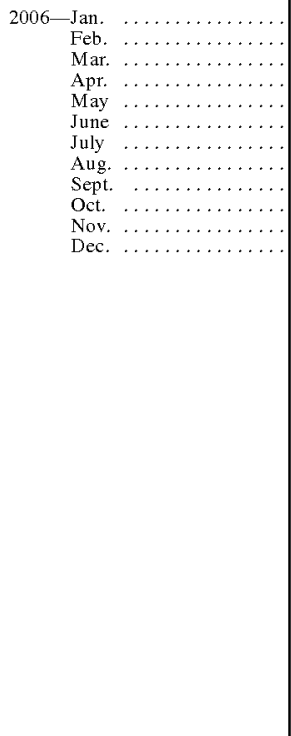 & $\begin{array}{l}7.26 \\
7.50 \\
7.53 \\
7.75 \\
7.93 \\
8.02 \\
8.25 \\
8.25 \\
8.25 \\
8.25 \\
8.25 \\
8.25\end{array}$ & 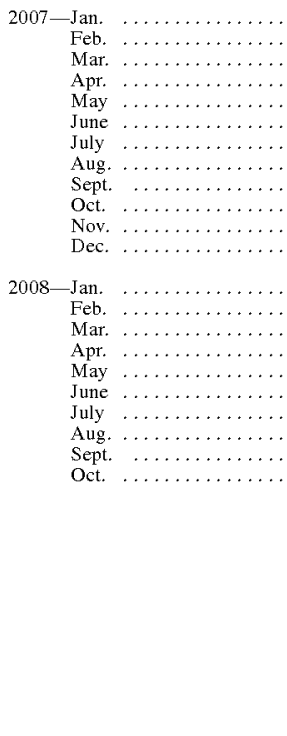 & $\begin{array}{l}8.25 \\
8.25 \\
8.25 \\
8.25 \\
8.25 \\
8.25 \\
8.25 \\
8.25 \\
8.03 \\
7.74 \\
7.50 \\
7.33 \\
6.98 \\
6.00 \\
5.66 \\
5.24 \\
5.00 \\
5.00 \\
5.00 \\
5.00 \\
5.00 \\
4.56\end{array}$ \\
\hline
\end{tabular}

1. The prime rate is one of several base rates that banks use to price short-term business loans. The table shows the date on which a new rate came to be the predominant one quoted by a majority of the twenty-five largest banks by asset size, based on the most recent Call

Report. Data in this table also appear in the Board's H.15 (519) weekly statistical release, available on the Board's website, www.federalreserve.gov/releases. 
1.35 INTEREST RATES Money and Capital Markets

Percent per year; figures are averages of business day data unless otherwise noted

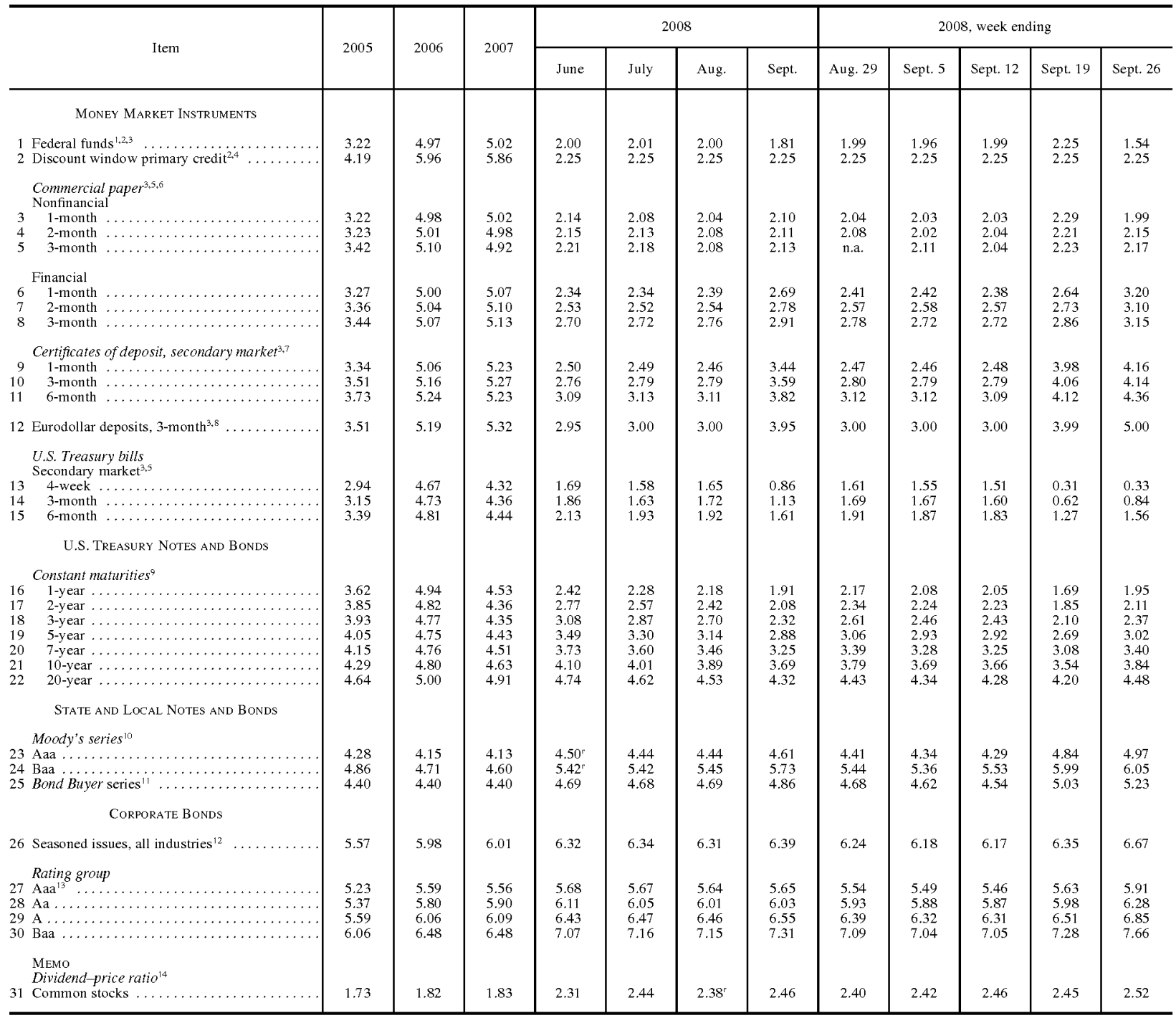

Note: Some of the data in this table also appear in the Board's H.15 (519) weekly

statistical release, available at www.federalreserve.gov/releases.
1 . The daily effective federal funds rate is a weighted average of rates on trades through New York brokers.

2 . Weekly figures are averages of seven calendar days, ending on Wednesday of the current week; monthly figures include each calendar day in the month.

3. Annualized using a 360-day year or bank interest. Source: U.S. Treasury

4. The rate charged for discounts made and advances extended under the Federal Reserve's primary credit discount window program, which became effective January 9, 2003. This rate replaces that for adjustment credit, which was discontinued after January 8, 2003. For further information, see www.federalreserve.gov/boarddocs/press/bcreg/2002/200210312 default.htm. The rate reported is that for the Federal Reserve Bank of New York. Historical series for the rate on adjustment credit is available at www.federalreserve.gov/releases/h15/ data.htm

5. Quoted on a discount basis

6. Interest rates interpolated from data on certain commercial paper trades settled by the Depository Trust Company. The trades represent sales of commercial paper by dealers or direct issuers to investors (that is, the offer side). See the Board's Commercial Paper webpages (www.federalreserve.gov/releases/cp) for more information.

7. An average of dealer offering rates on nationally traded certificates of deposit.

8. Bid rates for Eurodollar deposits collected around 9:30 a.m. Eastern time. Data are for indication purposes only.

9. Yields on actively traded issues adjusted to constant maturities. Source: U.S. Treasury

10. General obligation bonds based on Thursday figures; Moody's Investors Service.

11. State and local government general obligation bonds maturing in 20 years are used in compiling this index. The 20 -bond index has a rating roughly equivalent to Moody's A

rating. Based on Thursday figures.
12. Daily figures are averages of $\mathrm{Aaa}, \mathrm{Aa}, \mathrm{A}$, and Baa yields from Moody's Investors Service. Based on yields to maturity on selected long-term bonds.

13. Effective December 7, 2001, the Moody's Aaa yield includes yields only for industrial firms. Prior to December 7, 2001, the Aaa yield represented both utilities and industrial.

14. Standard \& Poor's corporate series. Common stock ratio is based on the 500 stocks in the price index 


\begin{tabular}{|c|c|c|c|c|c|c|c|c|c|c|c|c|}
\hline \multirow{2}{*}{ Indicator } & \multirow{2}{*}{2005} & \multirow{2}{*}{2006} & \multirow{2}{*}{2007} & \multicolumn{9}{|c|}{2008} \\
\hline & & & & Feb. & Mar. & Apr. & May & June & July & Aug. & Sept. & Oct. \\
\hline \multicolumn{13}{|c|}{ and trading volume (averages of daily figures) } \\
\hline \multicolumn{13}{|l|}{ Common stock prices (indexes) } \\
\hline $\begin{array}{l}1 \text { New York Stock Exchange } \\
\text { (Dec. 31, 1965=50) }\end{array}$ & $7,351.19$ & $8,357.63$ & $9,653.00$ & $9,041.52$ & $8,776.21$ & $9,174.10$ & $9,429.04$ & $8,996.98$ & $8,427.37$ & $8,362.20$ & $7,886.29$ & $6,130.39$ \\
\hline 2 Industrial $\ldots \ldots \ldots \ldots$ & na. & na. & n.a. & n.a. & na. & n.a. & n.a. & & n.a. & & n.a. & \\
\hline 3 Transportation ........ & & n.a. & n.a. & n.a. & n.a. & n.a. & n.a. & n.a. & n.a. & n.a. & n.a. & n.a. \\
\hline $4 \quad$ Utility ... & & n.a. & & & & & & & & & & \\
\hline 5 Finance $\ldots \ldots \ldots \ldots$ & & n.a. & n.a. & n.a. & n.a. & n.a. & n.a. & n.a. & n.a. & n.a. & n.a. & n.a. \\
\hline $\begin{array}{l}6 \text { Standard \& Poor's Corporation } \\
(1941-43=10)^{1} \ldots \ldots \ldots\end{array}$ & $1,207.23$ & $1,310.46$ & $1,477.19$ & $1,354.87$ & $1,316.94$ & $1,370.47$ & $1,403.22$ & $1,341.25$ & $1,257.33$ & $1,281.47$ & $1,216.93$ & 968.80 \\
\hline $\begin{array}{r}7 \text { American Stock Exchange } \\
\quad(\text { Aug. } 31,1973=50)^{2}\end{array}$ & $1,567.52$ & $1,936.79$ & $2,267.99$ & $2,269.79$ & $2,262.29$ & $2,297.06$ & $2,351.25$ & $2,293.07$ & $2,153.19$ & $2,078.76$ & $1,889.93$ & $1,468.58$ \\
\hline \multirow{2}{*}{ 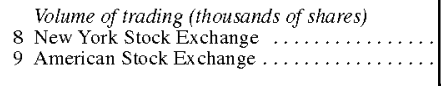 } & & & & & & & & & & & & \\
\hline & $\begin{array}{c}1,542,724 \\
\text { n.a. }\end{array}$ & $\begin{array}{c}2,254,869 \\
\text { n.a. }\end{array}$ & $\left|\begin{array}{c}3,232,195 \\
\text { n.a. }\end{array}\right|$ & $\begin{array}{c}3,832,107 \\
\text { n.a. }\end{array}$ & $\left|\begin{array}{c}4,601,666 \\
\text { n.a. }\end{array}\right|$ & $\begin{array}{c}3,829,875 \\
\text { n.a. }\end{array} \mid$ & $\mid \begin{array}{c}3,774,019 \\
\text { n.a. }\end{array}$ & $\left|\begin{array}{c}4,482,650 \\
\text { n.a. }\end{array}\right|$ & $\left|\begin{array}{c}5,589,370 \\
\text { n.a. }\end{array}\right|$ & $\begin{array}{c}4,226,522 \\
\text { n.a. }\end{array}$ & $\mid \begin{array}{c}6,602,084 \\
\text { n.a. }\end{array}$ & $\begin{array}{l}6,880,451 \\
\text { n.a. }\end{array}$ \\
\hline & \multicolumn{12}{|c|}{ Customer financing (millions of dollars, end-of-period balances) } \\
\hline 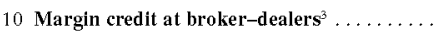 & 221,660 & 275,380 & 285,610 & $\mathbf{3 3 4}, 900$ & 311,660 & 295,550 & 310,310 & 314,360 & 313,290 & 292,110 & 299,960 & 233,350 \\
\hline Free credit balances at brokers ${ }^{4}$ & & & & & & & & & & & & \\
\hline \multirow{4}{*}{$\begin{array}{l}11 \text { Margin accounts }{ }^{5} \ldots \ldots \ldots \ldots \ldots \ldots \ldots \ldots \ldots \ldots \ldots \ldots \ldots \ldots \ldots \ldots \ldots \\
12 \text { Cash accounts } \ldots \ldots \ldots \ldots \ldots \ldots\end{array}$} & 119,710 & 159,040 & 156,190 & 266,050 & 305,600 & 313,740 & 325,040 & 351,340 & 370,200 & 385,850 & 193,350 & 186,870 \\
\hline & 88,730 & 94,450 & 90,340 & 133,670 & 122,140 & 100,600 & 95,930 & 96,090 & 98,890 & 90,860 & 106,370 & 100,330 \\
\hline & \multicolumn{12}{|c|}{ Margin requirements (percent of market value and effective date) ${ }^{6}$} \\
\hline & \multicolumn{2}{|c|}{ Mar. 11, 1968} & \multicolumn{2}{|c|}{ June 8,1968} & \multicolumn{2}{|c|}{ May 6, 1970} & \multicolumn{2}{|c|}{ Dec. 6, 1971} & \multicolumn{2}{|c|}{ Nov. 24,1972} & \multicolumn{2}{|c|}{ Jan. 3, 1974} \\
\hline 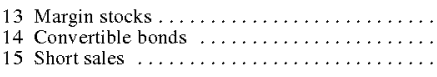 & \multicolumn{2}{|c|}{$\begin{array}{l}70 \\
50 \\
70\end{array}$} & \multicolumn{2}{|c|}{$\begin{array}{l}80 \\
60 \\
80\end{array}$} & \multicolumn{2}{|c|}{$\begin{array}{l}65 \\
50 \\
65\end{array}$} & \multicolumn{2}{|c|}{$\begin{array}{l}55 \\
50 \\
55\end{array}$} & \multicolumn{2}{|c|}{$\begin{array}{l}65 \\
50 \\
65\end{array}$} & \multicolumn{2}{|c|}{$\begin{array}{l}50 \\
50 \\
50\end{array}$} \\
\hline \multicolumn{5}{|c|}{$\begin{array}{l}\text { 1. In July } 1976 \text { a financial group made up of banks and insurance companies was added to } \\
\text { the group of stocks on which the index is based. The index is now based on } 400 \text { industrial } \\
\text { stocks (formerly } 425 \text { ), } 20 \text { transportation (formerly } 15 \text { rail), } 40 \text { public utility (formerly } 60 \text { ), and } \\
40 \text { financial. } \\
\text { 2. On July } 5,1983 \text {, the American Stock Exchange rebased its index, effectively cutting } \\
\text { previous readings in half. } \\
\text { 3. Since July } 1983 \text {, under the revised Regulation T, margin credit at broker-dealers has } \\
\text { included credit extended against stocks, convertible bonds, stocks acquired through the } \\
\text { exercise of subscription rights, corporate bonds, and government securities. Separate report- } \\
\text { ing of data for margin stocks, convertible bonds, and subscription issues was discontinued in } \\
\text { April } 1984 \text {. } \\
\text { 4. Free credit balances are amounts in accounts with no unfulfilled commitments to } \\
\text { brokers and are subject to withdrawal by customers on demand. } \\
\text { 5. Series initiated in June } 1984 \text {. }\end{array}$} & \multicolumn{8}{|c|}{$\begin{array}{l}\text { 6. Margin requirements, stated in regulations adopted by the Board of Governors pursuant } \\
\text { to the Securities Exchange Act of } 1934 \text {, limit the amount of credit that can be used to } \\
\text { purchase and carry "margin securities" (as defined in the regulations) when such credit is } \\
\text { collateralized by securities. Margin requirements on securities are the difference between the } \\
\text { market value ( } 100 \text { percent) and the maximum loan value of collateral as prescribed by the } \\
\text { Board. Regulation T was adopted effective Oct. } 15,1934 \text {; Regulation U, effective May } 1 \text {, } \\
\text { 1936; Regulation G, effective Mar. } 11,1968 \text {; and Regulation X, effective Nov. } 1,1971 \text {. } \\
\text { On Jan. } 1,1977 \text {, the Board of Governors for the first time established in Regulation T the } \\
\text { initial margin required for writing options on securities, setting it at } 30 \text { percent of the current } \\
\text { market value of the stock underlying the option. On Sept. } 30,1985 \text {, the Board changed the } \\
\text { required initial margin, allowing it to be the same as the option maintenance margin required } \\
\text { by the appropriate exchange or self-regulatory organization; such maintenance margin rules } \\
\text { must be approved by the Securities and Exchange Commission. }\end{array}$} \\
\hline
\end{tabular}


1.40 FEDERAL DEBT SUBJECT TO STATUTORY LIMITATION

Billions of dollars, end of month

\begin{tabular}{|c|c|c|c|c|c|c|c|c|c|}
\hline \multirow{2}{*}{ Item } & \multicolumn{2}{|c|}{2006} & \multicolumn{4}{|c|}{2007} & \multicolumn{3}{|c|}{2008} \\
\hline & Sept. 30 & Dec. 31 & Mar. 31 & June 30 & Sept. 30 & Dec. 31 & Mar. 31 & June 30 & Sept 30 \\
\hline 1 Federal debt outstanding . . & $8,530.4$ & $8,703.7$ & $8,872.9$ & $8,890.8$ & $9,030.6$ & $9,252.3$ & $9,461.1$ & $9,515.5$ & $10,047.8^{r}$ \\
\hline 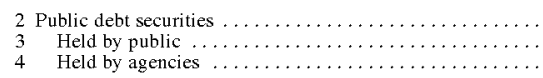 & $\begin{array}{l}8,507.0 \\
4,843.2 \\
3,663.8\end{array}$ & $\begin{array}{l}8,680.2 \\
4,901.2 \\
3,779.0\end{array}$ & $\begin{array}{l}8,849.7 \\
5,054.3 \\
3,795.4\end{array}$ & $\begin{array}{l}8,867.7 \\
4,943.0 \\
3,924.6\end{array}$ & $\begin{array}{l}9,007.7 \\
5,049.2 \\
3,958.4\end{array}$ & $\begin{array}{l}9,229.2 \\
5,136.3 \\
4,092.9\end{array}$ & $\begin{array}{l}9,437.6 \\
5,334.0 \\
4,103.6\end{array}$ & $\begin{array}{l}9,492.0 \\
5,285.0 \\
4,207.0\end{array}$ & $\begin{array}{r}10,024.7^{\prime} \\
5,814.2^{\prime} \\
4,210.5^{\prime}\end{array}$ \\
\hline 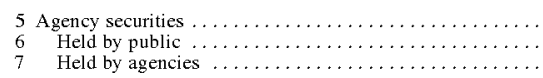 & $\begin{array}{r}23.4 \\
23.4 \\
.0\end{array}$ & $\begin{array}{r}23.5 \\
23.5 \\
.0\end{array}$ & $\begin{array}{r}23.2 \\
23.2 \\
.0\end{array}$ & $\begin{array}{r}23.2 \\
23.2 \\
.0\end{array}$ & $\begin{array}{r}23.0 \\
23.0 \\
.0\end{array}$ & $\begin{array}{r}23.1 \\
23.1 \\
.0\end{array}$ & $\begin{array}{r}23.5 \\
23.5 \\
.0\end{array}$ & $\begin{array}{r}23.5 \\
23.5 \\
.0\end{array}$ & $\begin{array}{r}23.1^{r} \\
23.1^{r} \\
\quad .0^{r}\end{array}$ \\
\hline 8 Debt subject to statutory limit & $8,420.3$ & $8,592.5$ & $8,760.7$ & $8,779.2$ & $8,921.3$ & $9,144.7$ & $9,358.1$ & $9,427.9$ & $9,959.8^{1}$ \\
\hline 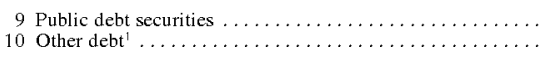 & $\begin{array}{r}8,420.2 \\
.1\end{array}$ & $\begin{array}{r}8,592.4 \\
.1\end{array}$ & $\begin{array}{r}8,760.7 \\
.1\end{array}$ & $\begin{array}{r}8,779.1 \\
.1\end{array}$ & $\begin{array}{r}8,921.3 \\
.1\end{array}$ & $\begin{array}{r}9,144.6 \\
.1\end{array}$ & $\begin{array}{r}9,358.1 \\
.1\end{array}$ & $\begin{array}{r}9,427.8 \\
.1\end{array}$ & $\begin{array}{r}9,959.8^{r} \\
.1^{\prime}\end{array}$ \\
\hline $\begin{array}{l}\text { Memo } \\
11 \text { Statutory debt limit }\end{array}$ & $8,965.0$ & $8,965.0$ & $8,965.0$ & $8,965.0$ & $9,815.0$ & $9,815.0$ & $9,815.0$ & $9,815.0$ & $10,615.0^{r}$ \\
\hline
\end{tabular}

1. Consists of guaranteed debt of U.S. Treasury and other federal agencies, specified participation certificates, notes to international lending organizations, and District of Columbia stadium bonds.

SourCE: U.S. Department of the Treasury, Monthly Statement of the Public Debt of the United States and Monthly Treasury Statement.

1.41 GROSS PUBLIC DEBT OF U.S. TREASURY Types and Ownership

Billions of dollars, end of period

\begin{tabular}{|c|c|c|c|c|c|c|c|c|c|}
\hline \multirow{2}{*}{\multicolumn{2}{|c|}{ Type and holder }} & \multirow{2}{*}{2004} & \multirow{2}{*}{2005} & \multirow{2}{*}{2006} & \multirow{2}{*}{2007} & 2007 & \multicolumn{3}{|c|}{2008} \\
\hline & & & & & & Q4 & Q1 & Q2 & Q3 \\
\hline 1 & Total gross public debt & $7,596.1$ & $8,170.4$ & $8,680.2$ & $9,229.2$ & $9,229.2$ & $9,437.6$ & $9,492.0$ & $10,024.7$ \\
\hline & By type & & & & & & & & \\
\hline 2 & Interest-bearing & $7,578.5$ & $8,117.0$ & $8,627.5$ & $9,207.5$ & $9,207.5$ & $9,416.6$ & $9,471.5$ & $10,004.7$ \\
\hline 3 & 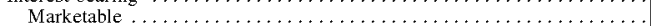 & 3.959 .7 & $4,184.0$ & $4,413.9$ & $4,536.6$ & $4,536.6$ & $4,732.4$ & $4,696.4$ & $5,236.0$ \\
\hline 4 & 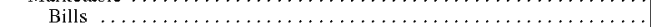 & $1,003.2$ & 963.9 & 944.2 & $1,003.9$ & $1,003.9$ & $1,158.4$ & $1,060.5$ & $1,489.8$ \\
\hline 5 & 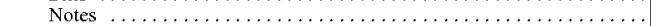 & $2,157.1$ & $2,326.8$ & $2,409.9$ & $2,488.4$ & $2,488.4$ & $2,514.0$ & $2,543.4$ & $2,624.7$ \\
\hline 6 & 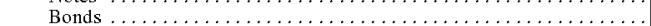 & 539.5 & 516.6 & 530.6 & 558.5 & 558.5 & 571.8 & 581.0 & 582.8 \\
\hline 7 & Inflation-indexed notes and bonds ${ }^{1} \ldots \ldots \ldots \ldots \ldots \ldots \ldots \ldots \ldots$ & 245.9 & 328.7 & 411.2 & 471.7 & 471.7 & 474.1 & 497.5 & 524.5 \\
\hline 8 & Nonmarketable $^{2} \ldots \ldots \ldots \ldots \ldots \ldots$ & $3,618.8$ & $3,986.5$ & $4,338.3$ & $4,692.6$ & $4,692.6$ & $4,705.2$ & $4,795.6$ & $4,788.7$ \\
\hline 9 & State and local government series & 160.7 & 235.6 & 257.6 & 293.2 & 293.2 & 286.3 & 275.2 & 260.2 \\
\hline 10 & Foreign issues ${ }^{3} \ldots \ldots \ldots \ldots \ldots$ & 5.9 & 3.8 & 3.0 & 3.0 & 3.0 & 4.9 & 3.1 & 3.0 \\
\hline 11 & Government & 5.9 & 3.8 & 3.0 & 3.0 & 3.0 & 4.9 & 3.1 & 3.0 \\
\hline 12 & Public ..... & .0 & .0 & .0 & .0 & .0 & .0 & .0 & .0 \\
\hline 13 & Savings bonds and notes & 191.7 & 191.2 & 187.7 & 180.5 & 180.5 & 179.4 & 178.8 & 177.9 \\
\hline 14 & Government account series ${ }^{4}$ & $3,230.6$ & $3,506.6$ & $3,839.4$ & $4,164.3$ & $4,164.3$ & $4,183.7$ & $4,288.1$ & $4,297.7$ \\
\hline 15 & Non-interest-bearing $\ldots \ldots \ldots \ldots$ & 17.6 & 53.4 & 124.6 & 21.7 & $\begin{array}{r}4,104.5 \\
21.7\end{array}$ & $\begin{array}{r}4,103.0 \\
21.0\end{array}$ & $\begin{array}{r}4,200.1 \\
20.5\end{array}$ & 20.0 \\
\hline & By holder ${ }^{5}$ & & & & & & & & \\
\hline 16 & U.S. Treasury and other federal agencies and trust funds. & $3,189.1$ & $3,466.9$ & $3,783.1$ & $4,097.8$ & $4,097.8$ & $4,108.2$ & $4,212.5$ & $4,196.3$ \\
\hline 17 & Federal Reserve Banks ${ }^{6} \ldots \ldots \ldots \ldots \ldots \ldots \ldots \ldots$ & 717.8 & 744.2 & 778.9 & 740.6 & 740.6 & 591.2 & 478.8 & 476.6 \\
\hline 18 & 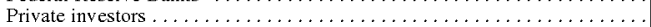 & $3,690.6$ & $3,970.6$ & $4,122.1$ & $4,395.7$ & $4,395.7$ & $4,742.9$ & $4,806.2$ & $5,344.2$ \\
\hline 19 & 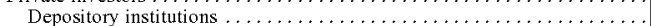 & 125.0 & 117.2 & 115.1 & 129.9 & 129.9 & 127.9 & 115.4 & n.a. \\
\hline 20 & 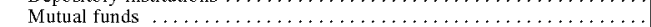 & 254.1 & 251.3 & 250.7 & 362.7 & 362.7 & 464.7 & 449.8 & n.a. \\
\hline 21 & 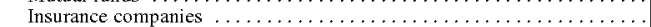 & 149.7 & 160.4 & 159.0 & 123.3 & 123.3 & 123.4 & 123.4 & n.a. \\
\hline 22 & $\begin{array}{l}\text { State and local treasuries } \\
\text { Individuals }\end{array}$ & 389.1 & $481.4^{r}$ & $516.9^{r}$ & 531.5 & 531.5 & 523.6 & 522.2 & n.a. \\
\hline 23 & Savings bonds ......... & 204.4 & 205.1 & 202.4 & 196.4 & 196.4 & 195.3 & 194.9 & n.a. \\
\hline 24 & Pension funds $\ldots \ldots \ldots \ldots \ldots \ldots$ & 321.5 & 335.0 & 346.2 & 376.1 & 376.1 & 387.1 & 393.3 & n.a. \\
\hline 25 & Private ... & 170.5 & 181.2 & 193.2 & 211.6 & 211.6 & 222.1 & 226.0 & n.a. \\
\hline 26 & State and Local & 151.0 & 153.8 & 153.0 & 164.5 & 164.5 & 165.0 & 167.3 & n.a. \\
\hline 27 & Foreign and international ${ }^{\mathrm{B}} \ldots \ldots$ & $1,853.4$ & $2,036.0$ & $2,105.0$ & $2,355.1$ & $2,355.1$ & $2,515.6$ & $2,647.9^{r}$ & $2,862.0$ \\
\hline 28 & Other miscellaneous investors $7, \ldots \ldots \ldots$ & 393.3 & $384.1^{\mathrm{r}}$ & $426.8^{r}$ & $320.7^{r}$ & $320.7^{r}$ & $405.1^{r}$ & 359.1 & n.a. \\
\hline
\end{tabular}

1. The U.S. Treasury first issued inflation-indexed securities during the first quarter of

2. Includes (not shown separately) securities issued to the Rural Electrification Administration, depository bonds, retirement plan bonds, and individual retirement bonds.

3. Nonmarketable series denominated in dollars, and series denominated in foreign currency held by foreigners.

4. Held almost entirely by U.S. Treasury and other federal agencies and trust funds

5. Data for Federal Reserve Banks and U.S. government agencies and trust funds are

actual holdings; data for other groups are Treasury estimates.
6 . U.S. Treasury securities bought outright by Federal Reserve Banks, see Bulletin table 18.

7. In March 1996, in a redefinition of series, fully defeased debt backed by nonmarketable federal securities was removed from "Other miscellaneous investors" and added to "State and local treasuries." The data shown here have been revised accordingly.

8. Includes nonmarketable foreign series Treasury securities and Treasury deposit funds Excludes Treasury securities held under repurchase agreements in custody accounts at the Federal Reserve Bank of New York.

9. Includes individuals, government-sponsored enterprises, brokers and dealers, bank personal trusts and estates, corporate and noncorporate businesses, and other investors.

SouRCES: Data by type of security, U.S. Treasury Department, Monthly Statement of the Public Debt of the United States; data by holder, Federal Reserve Board of Governors, Flow of Funds Accounts of the United States and U.S. Treasury Department, Treasury Bulletin. unless otherwise noted. 
1.42 U.S. GOVERNMENT SECURITIES DEALERS Transactions' Millions of dollars, daily averages

\begin{tabular}{|c|c|c|c|c|c|c|c|c|c|c|c|c|c|}
\hline \multirow{2}{*}{\multicolumn{2}{|c|}{ Item }} & \multicolumn{3}{|c|}{2008} & \multicolumn{9}{|c|}{2008 , week ending } \\
\hline & & June & July & Aug. & July 30 & Aug. 6 & Aug. 13 & Aug. 20 & Aug. 27 & Sept. 3 & Sept. 10 & Sept. 17 & Sept. 24 \\
\hline \multicolumn{2}{|r|}{ By type of security } & & & & & & & & & & & & \\
\hline \multicolumn{2}{|r|}{1 U.S. Treasury bills ..................... } & 61,827 & 65,406 & 66,098 & 63,849 & 61,090 & 58,155 & 69,550 & 73,358 & 69,188 & 66,199 & 113,615 & 149,069 \\
\hline \multirow{2}{*}{$\begin{array}{l}2 \\
3\end{array}$} & Three years or less ..................... & 227,557 & 185,916 & 137,407 & 180,937 & 136,218 & 128,931 & 119,613 & 145,722 & 184,672 & 197,721 & 258,272 & 259,145 \\
\hline & $\begin{array}{l}\text { More than three but less than or } \\
\text { equal to six years ........ }\end{array}$ & 160,239 & 150,371 & 129,538 & 156,891 & 132,615 & 125,935 & 115,755 & 120,547 & 189,330 & 209,695 & 211,518 & 169,862 \\
\hline \multirow[t]{2}{*}{4} & $\begin{array}{l}\text { More than six but less than or equal } \\
\text { to eleven years } \ldots \ldots \ldots \ldots \ldots\end{array}$ & 106,303 & 101,767 & 88,665 & 85,834 & 111,065 & 99,684 & 69,623 & 76,710 & 93,815 & 136,253 & 170,762 & 134,116 \\
\hline & More than eleven ............ & 29,340 & 23,323 & 24,810 & 21,355 & 27,442 & 34,426 & 21,536 & 17,423 & 22,163 & $\begin{array}{r}130,253 \\
30,526\end{array}$ & 45,179 & $\begin{array}{r}134,110 \\
42,872\end{array}$ \\
\hline $\begin{array}{l}5 \\
6\end{array}$ & Inflation-protected ${ }^{2}$ & 7,464 & 9,354 & 6,958 & 7,591 & 7,584 & 6,513 & 7,541 & 6,000 & 7,752 & 7,549 & 12,644 & 10,993 \\
\hline \multicolumn{14}{|c|}{$\begin{array}{l}\text { Federal agency and government- } \\
\text { sponsored enterprises }\end{array}$} \\
\hline 7 & $\begin{array}{l}\text { Discount notes .............. } \\
\text { Coupon securities by maturity }\end{array}$ & 88,570 & 86,911 & 78,465 & 81,732 & 84,154 & 79,593 & 78,905 & 73,614 & 75,293 & 78,609 & 96,766 & 127,863 \\
\hline \multirow{2}{*}{$\begin{array}{l}8 \\
9\end{array}$} & Three years or less ................ & 11,966 & 9,542 & 8,090 & 7,970 & 8,046 & 10,418 & 8,767 & 5,764 & 6,482 & 11,193 & 10,397 & 14,960 \\
\hline & $\begin{array}{l}\text { More than three years but less than } \\
\text { or equal to six years ........ } \\
\text { More than six years but less than }\end{array}$ & 3,998 & 3,543 & 4,359 & 3,189 & 6,063 & 2,945 & 4,657 & 4,991 & 2,158 & 2,947 & 6,368 & 3,281 \\
\hline 10 & or equal to eleven years ... & 2,493 & 2,653 & 1,491 & 1,856 & 1,557 & 1,457 & 1,288 & 1,761 & 1,281 & 2,139 & 2,788 & 3,679 \\
\hline 11 & More than eleven years .... & 407 & 447 & 423 & 586 & 453 & 324 & 374 & 584 & 326 & 508 & 1,590 & 2,562 \\
\hline & Mortgage-backed & 307,425 & 313,398 & 261,225 & 228,232 & 291,904 & 408,136 & 174,321 & 161,211 & 299,881 & 664,535 & 327,153 & 246,606 \\
\hline & Corporate securities & & & & & & & & & & & & \\
\hline & One year or less. & 169,488 & 160,939 & 150,365 & 145,744 & 150,084 & 151,429 & 144,284 & 154,680 & 152,683 & 158,050 & 136,190 & 196,290 \\
\hline & More than one year & 15,550 & 10,989 & 9,536 & 12,192 & 10,531 & 10,719 & 10,575 & 6,479 & 9,634 & 10,013 & 9,393 & 14,496 \\
\hline & \multicolumn{13}{|l|}{ By type of counterparty } \\
\hline & U.S. Treasury ...... & 255,267 & 228,546 & 191,296 & 218,873 & 196,816 & 193,047 & 172,234 & 185,746 & 237,412 & 273,993 & 331,653 & 297,433 \\
\hline & $\begin{array}{c}\text { Federal agency and government- } \\
\text { sponsored enterprises..... }\end{array}$ & 7.465 & 7,131 & 5,522 & 5.974 & 6.147 & 7,300 & 5,340 & 4,169 & 3,661 & 6.652 & 6,093 & 4,692 \\
\hline & Mortgage-backed .. & 79,189 & 93,820 & 68,778 & 78,113 & 62,373 & 121,837 & 46,181 & 41,102 & 74,628 & 152,476 & 74,346 & 50,649 \\
\hline & Corporate ...... & 556 & 447 & 428 & 475 & 660 & 402 & 349 & 415 & 261 & 690 & 283 & 465 \\
\hline & With other & & & & & & & & & & & & \\
\hline \multirow{2}{*}{$\begin{array}{l}199 \\
20\end{array}$} & U.S. Treasury $\ldots \ldots \ldots \ldots \ldots$ & 337,463 & 307,592 & 262,180 & 297,584 & 279,198 & 260,597 & 231,385 & 254,013 & 329,508 & 373,950 & 480,337 & 468,624 \\
\hline & sponsored enterprises ...... & 99,969 & 95,966 & 87,305 & 89,358 & 94,125 & 87,435 & 88,650 & 82,546 & 81,880 & 88,746 & 111,816 & 147,652 \\
\hline 21 & Mortgage-backed .. & 228,236 & 219,579 & 192,446 & 150,119 & 229,531 & 286,299 & 128,140 & 120,109 & 225,253 & 512,059 & 252,807 & 195,957 \\
\hline 22 & Corporate ... & 184,481 & 171,480 & 159,473 & 157,460 & 159,955 & 161,746 & 154,510 & 160,744 & 162,056 & 167,373 & 145,299 & 210,321 \\
\hline & $\begin{array}{l}\text { NoTE: Major changes in the report form } \\
\text { ler data series as of the week ending July } \\
\text { leral Reserve Bank of New York websit } \\
\text { ler the Primary Dealer heading. } \\
\text { The figures represent purchases and sal } \\
\text { urities dealers reporting to the Federal Re } \\
\text { lude all U.S. government, federal agenc }\end{array}$ & $\begin{array}{l}\text { led by pr } \\
2001 . \mathrm{Cr} \\
\text { (wwwny } \\
\text { sin the m } \\
\text { gerve Ban } \\
\text { gavernn }\end{array}$ & $\begin{array}{l}\text { ary dealer } \\
\text { nt weekly } \\
\text { b.org/mark } \\
\text { et by the } p \\
\text { f New Yo } \\
\text { t-sponsore }\end{array}$ & mary U. & $\begin{array}{l}\text { ak in the } \\
\text { nd at the } \\
\text { ers.html) } \\
\text { ernment } \\
\text { isactions } \\
\text { iortgage- }\end{array}$ & $\begin{array}{l}\text { back } \\
\text { U.S. } \\
\text { issue } \\
\text { agree } \\
2 . \\
\text { princ } \\
\text { ance }\end{array}$ & $\begin{array}{l}\text { Dernment } \\
\text { nts. Aver } \\
\text { tright Th } \\
\text { value, } \\
\text { amount }\end{array}$ & $\begin{array}{l}\text { ecurities } \\
\text { not incluc } \\
\text { es are bas } \\
\text { sury infli } \\
\text { eluding as } \\
\text { nadjusted }\end{array}$ & $\begin{array}{l}\text { schedule } \\
\text { led on a } \\
\text { ransactio } \\
\text { on the nu } \\
\text { in-protect } \\
\text { ied intere } \\
\text { inflation }\end{array}$ & $\begin{array}{l}\text { or immed } \\
\text { en-issued } \\
\text { under rep } \\
\text { er of trad } \\
\text { securitie } \\
\text { where pr } \\
\text { mes the p }\end{array}$ & $\begin{array}{l}\text { e and forv } \\
\text { asis betw } \\
\text { hase and } \\
\text { days in } \\
\text { TIPS) tr } \\
\text { ipal valu } \\
\text { e times th }\end{array}$ & $\begin{array}{l}\text { d delivery, } \\
\text { the annol } \\
\text { erse repur } \\
\text { week. } \\
\text { actions ar } \\
\text { flects the } \\
\text { idex ratio. }\end{array}$ & $\begin{array}{l}\text { s well as all } \\
\text { cement and } \\
\text { lase (resale) } \\
\text { reported at } \\
\text { iginal issu- }\end{array}$ \\
\hline
\end{tabular}


1.43 U.S. GOVERNMENT SECURITIES DEALERS Positions and Financing ${ }^{1}$

Millions of dollars

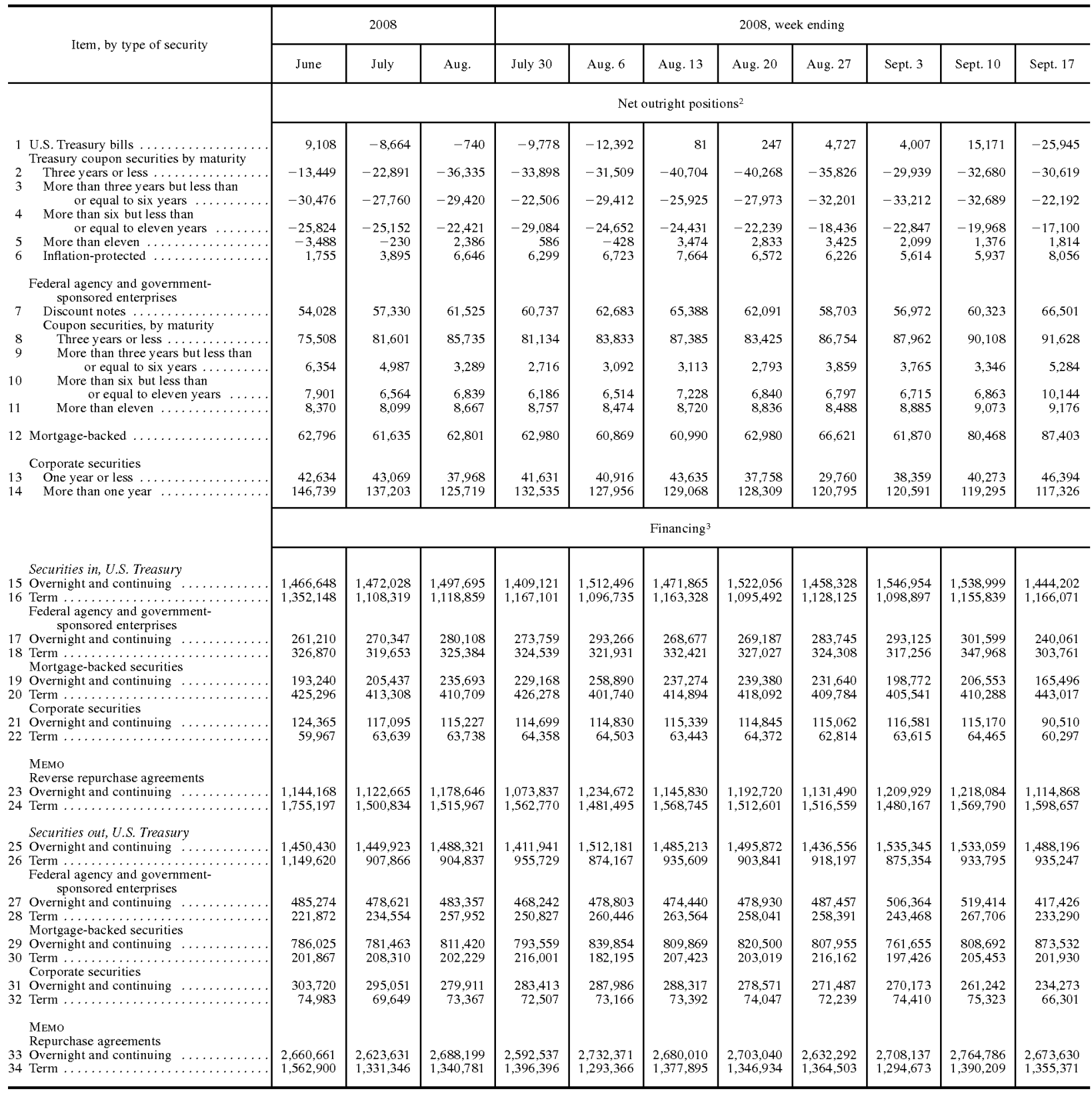

NotE: Major changes in the report form filed by primary dealers included a break in many series as of the week ending July 4, 2001. Current weekly data may be found at the Federal Reserve Bank of New York website (www.ny.frb.org/markets/primarydealers.html) under the Primary Dealer heading.

1. Data for positions and financing are obtained from reports submitted to the Federal Reserve Bank of New York by the US government securities dealers on its published list of primary dealers. Weekly figures are close-of-business Wednesday data. Positions for calend prins of the report week are assumed to be constant. Monthly averages are based on the number of calendar days in the month.

2. Net outright positions include all U.S. government, federal agency, governmentsponsored enterprise, mortgage-backed, and corporate securities scheduled for immediate and forward delivery, as well as U.S. government securities traded on a when-issued basis between the announcement and issue date.

3. Figures cover financing U.S. government, federal agency, government-sponsored enterprise, mortgage-backed, and corporate securities. Financing transactions for Treasury inflation-protected securities (TIPS) are reported in actual funds paid or received, except fo pledged securities. TIPS that are issued as pledged securities are reported at par value, which is the value of the security at original issuance (unadjusted for inflation). 
1.44 FEDERAL AND FEDERALLY SPONSORED CREDIT AGENCIES Debt Outstanding

Millions of dollars, end of period

\begin{tabular}{|c|c|c|c|c|c|c|c|c|c|c|}
\hline \multirow{2}{*}{\multicolumn{2}{|c|}{ Agency }} & \multirow{2}{*}{2004} & \multirow{2}{*}{2005} & \multirow{2}{*}{2006} & \multirow{2}{*}{2007} & \multicolumn{5}{|c|}{2008} \\
\hline & & & & & & Mar. & Apr. & May & June & July \\
\hline 1 & Federal and federally sponsored agencies $\ldots \ldots \ldots \ldots \ldots \ldots$ & n.a. & n.a. & n.a. & n.a. & n.a. & n.a. & n.a. & n.a. & n.a. \\
\hline & Federal agencies & 24,267 & 23,843 & 23,520 & 23,151 & 23,470 & 23,169 & 23,176 & 23,533 & n.a. \\
\hline & Defense Department ${ }^{1}$ & & & & & & 6 & 6 & 6 & n.a. \\
\hline & 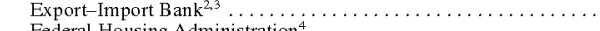 & n.a. & n.a. & n.a. & n.a. & n.a. & n.a. & n.a. & n.a. & n.a. \\
\hline $\begin{array}{l}3 \\
6\end{array}$ & $\begin{array}{l}\text { Federal Housing Administration } \\
\text { Government National Mortgage Association certificates of }\end{array}$ & 207 & 161 & 110 & 84 & 69 & 66 & 67 & 65 & n.a. \\
\hline & 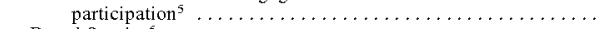 & n.a. & n.a. & n.a. & n.a. & n.a. & n.a. & n.a. & n.a. & n.a. \\
\hline 7 & Postal Service ${ }^{6} \ldots \ldots \ldots$ & n.a. & n.a. & n.a. & n.a. & n.a. & n.a. & n.a. & n.a. & n.a. \\
\hline 8 & Tennessee Valley Authority ........... & 24,261 & 23,837 & 23,514 & 23,145 & 23,464 & 23,163 & 23,170 & 23,527 & n.a. \\
\hline & United States Railway Association ${ }^{6} \ldots$ & n.a. & n.a. & n.a. & n.a. & n.a. & n.a. & n.a. & n.a. & n.a. \\
\hline 10 & Federally sponsored agencies ${ }^{7}$ & n.a. & n.a. & n.a. & n.a. & n.a. & n.a. & n.a. & n.a. & n.a. \\
\hline & Federal Home Loan Banks & 854,815 & 921,793 & n.a. & n.a. & n.a. & n.a. & n.a. & n.a. & n.a. \\
\hline & Federal Home Loan Mortgage Corporation $\ldots \ldots \ldots \ldots \ldots$ & 733,400 & 773,600 & n.a. & n.a. & n.a. & n.a. & n.a. & n.a. & n.a. \\
\hline & Federal National Mortgage Association $\ldots \ldots \ldots \ldots \ldots \ldots$ & 949,510 & 754,535 & n.a. & n.a. & n.a. & n.a. & n.a. & n.a. & n.a. \\
\hline 14 & Farm Credit Banks ${ }^{8} \ldots \ldots \ldots \ldots \ldots$ & 97,266 & 113,021 & n.a. & n.a. & n.a. & n.a. & n.a. & n.a. & n.a. \\
\hline & Student Loan Marketing Association ${ }^{9}$ & 78,121 & 91,929 & n.a. & n.a. & n.a. & n.a. & n.a. & n.a. & n.a. \\
\hline 16 & Financing Corporation ${ }^{10} \ldots \ldots \ldots$ & 8,170 & 8,170 & n.a. & n.a. & n.a. & n.a. & n.a. & n.a. & n.a. \\
\hline & Farm Credit Financial Assistance Corporation" & 1,261 & 1,261 & n.a. & n.a. & n.a. & n.a. & n.a. & n.a. & n.a. \\
\hline & Resolution Funding Corporation ${ }^{12} \ldots \ldots \ldots \ldots$ & 29,996 & 29,996 & n.a. & n.a. & n.a. & n.a. & n.a. & n.a. & n.a. \\
\hline 19 & $\begin{array}{l}\text { MEMo } \\
\text { Federal Financing Bank debt }{ }^{13} \text {.. }\end{array}$ & 27,948 & 28,325 & 30,304 & 32,422 & 30,463 & 29,772 & 30,937 & 30,999 & n \\
\hline & Lending to federal and federally sponsored agencies & & & & & & & & & \\
\hline 20 & Export-Import Bank ${ }^{3} \ldots \ldots \ldots \ldots \ldots \ldots \ldots \ldots$ & n.a. & n.a. & n.a. & n.a. & n.a. & n.a. & n.a. & n.a. & n.a. \\
\hline & Postal Service ${ }^{6} \ldots \ldots$. & n.a. & n.a. & n.a. & n.a. & n.a. & n.a. & n.a. & n.a. & n.a. \\
\hline & Student Loan Marketing Association & n.a. & n.a. & na. & n.a. & n.a. & n.a. & n.a. & n.a. & n.a. \\
\hline 23 & Tennessee Valley Authority . . . . . . . . . & n.a. & n.a. & n.a. & n.a. & n.a. & n.a. & n.a. & n.a. & n.a. \\
\hline 24 & United States Railway Association ${ }^{6} \quad \ldots \ldots$ & n.a. & n.a. & n.a. & n.a. & n.a. & n.a. & n.a. & 11.a. & n.a. \\
\hline & Other lending ${ }^{14}$ & & & & & & & & & \\
\hline & Farmers Home Administration & 16,961 & 18,515 & n.a. & n.a. & n.a. & n.a. & n.a. & n.a. & n.a. \\
\hline & Rural Electrification Administration & n.a. & n.a. & n.a. & n.a. & n.a. & n.a. & n.a. & n.a. & n.a. \\
\hline & Other $\ldots \ldots \ldots \ldots \ldots \ldots \ldots$ & 10,987 & 9,810 & 30,304 & 32,422 & 30,463 & 29,772 & 30,937 & 30,999 & n.a. \\
\hline
\end{tabular}

1. Consists of mortgages assumed by the Defense Department between 1957 and 1963

10. The Financing Corporation, established in August 1987 to recapitalize the Federa under family housing and homeowners' assistance programs.

2. Includes participation certificates reclassified as debt beginning Oct. 1, 1976

3. On-budget since Sept. 30,1976 .

4. Consists of debentures issued in payment of Federal Housing Administration insurance claims. Once issued, these securities may be sold privately on the securities market.

5. Certificates of participation issued before fiscal year 1969 by the Government National Mortgage Association acting as trustee for the Farmers Home Administration; the Department of Health. Education, and Welfare; the Department of Housing and Urban Development; the Small Business Administration; and the Veterans Administration.

6. Off-budget.

6. Off-budget.
7. Includes outstanding noncontingent liabilities: notes, bonds, and debentures. Includes Federal Agricultural Mortgage Corporation; therefore, details do not sum to total. Some data Federal Agricultural Mortgage Corporation; therefore, details do not sum to total. Some data
are estimated.

8. Excludes borrowing by the Farm Credit Financial Assistance Corporation, which is shown on line 17.

Before late 1982, the association obtained financing through the Federal Financing Bank Savings and Loan Insurance Corporation, undertook its first borrowing in October 1987. 11. The Farm Credit Financial Assistance Corporation, established in January 1988 to provide assistance to the Farm Credit System, undertook its first borrowing in July 1988.

12. The Resolution Funding Corporation, established by the Financial Institutions 12. The Resolution Funding Corporation, established by the Financial Institutions
Reform, Recovery, and Enforcement Act of 1989, undertook its first borrowing in October 1989.

13. The FFB, which began operations in 1974, is authorized to purchase or sell obligations issued, sold, or guaranteed by other federal agencies. Because FFB incurs debt solely for the issued, sold, or guaranteed by other federal agencies. Because FFB incurs debt solely for the
purpose of lending to other agencies, its debt is not included in the main portion of the table to purpose of lending to 0

14. Includes FFB purchases of agency assets and guaranteed loans; the latter are loans
avoid double counting. guaranteed by numerous agencies, with the amounts guaranteed by any one agency generally guaranteed by numerous agencies, with the amounts guaranteed by any one agency generally
being small. The Farmers Home Administration entry consists exclusively of agency assets. whereas the Rural Electrification Administration entry consists of both agency assets and guaranteed loans. 
1.45 NEW SECURITY ISSUES State and Local Governments

Millions of dollars

\begin{tabular}{|c|c|c|c|c|c|c|c|c|c|c|c|}
\hline \multirow{2}{*}{$\begin{array}{c}\text { Type of issue or issuer, } \\
\text { or use }\end{array}$} & \multirow{2}{*}{2005} & \multirow{2}{*}{2006} & \multirow{2}{*}{2007} & \multicolumn{8}{|c|}{2008} \\
\hline & & & & Feb. ${ }^{r}$ & Mar? & Apr. ${ }^{r}$ & May" & June $^{r}$ & July ${ }^{r}$ & Aug. ${ }^{r}$ & Sept. \\
\hline 1 All issues, new and refunding' & 409,802 & 389,540 & 426,208 & 21,352 & 43,101 & $\mathbf{5 0 , 9 2 6}$ & 43,119 & 49,446 & 37,612 & 31,096 & 20,839 \\
\hline By type of issue & & & & & & & & & & & \\
\hline 2 General obligation & 145,845 & 115,128 & 130,475 & 11,311 & 11,120 & 15,219 & 9,680 & 12,702 & 9,921 & 8,731 & 6,466 \\
\hline 3 Revenue...$\ldots \ldots \ldots$ & 263,957 & 274,413 & 295,734 & 10,041 & 31,981 & 35,707 & 33,439 & 36,744 & 27,691 & 22,365 & 14,373 \\
\hline By type of issuer & & & & & & & & & & & \\
\hline 4 State & 31,568 & 28,258 & 34,992 & 3,707 & 3,777 & 6,427 & 2,273 & 3,880 & 2,480 & 1,308 & 1,702 \\
\hline 5 Special district or statutory authority ${ }^{2}$ & 298,762 & 293,403 & 315,292 & 12,593 & 33,444 & 33,603 & 34,302 & 36,594 & 27,080 & 23,873 & 15,345 \\
\hline 6 Municipality, county, or township & 79,472 & 67,879 & 75,924 & 5,053 & 5,880 & 10,896 & 6,544 & 8,972 & 8,051 & 5,915 & 3,792 \\
\hline 7 Issues for new capital ............ & 222,986 & 262,485 & 275,281 & 14,813 & 21,237 & 22,243 & 20,268 & 26,490 & 21,448 & 17,493 & 11,596 \\
\hline By use of proceeds & & & & & & & & & & & \\
\hline 8 Education ...... & 70,974 & 70,252 & 70,921 & 4,539 & 3,863 & 4,922 & 5,267 & 8,659 & 5,110 & 4,632 & 2,919 \\
\hline 9 Transportation & 25,427 & 30,232 & 27,912 & 420 & 4,725 & 1,171 & 1,891 & 2,833 & 5,781 & 617 & 847 \\
\hline 10 Utilities and conservation & 10,052 & 7,801 & 11,416 & 3,450 & 1,962 & 413 & 529 & 503 & 1,618 & 565 & 226 \\
\hline 11 Social welfare $\ldots \ldots \ldots \ldots \ldots$ & n.a. & n.a. & n.a. & n.a. & n.a. & n.a. & n.a. & n.a. & n.a. & n.a. & n.a. \\
\hline 12 Industrial aid & 17,655 & 35,000 & 38,114 & 1,342 & 2,904 & 3,418 & 2,732 & 3,494 & 1,438 & 2,053 & 891 \\
\hline 13 Other purposes. & 60,626 & 72,684 & 82,846 & 3,799 & 5,594 & 9,221 & 4,849 & 7,042 & 5,513 & 5,729 & 4,043 \\
\hline
\end{tabular}

1. Par amounts of long-term issues based on date of sale.

2. Includes school districts.

Source: Securities Data Company beginning January 1990; Investment Dealer's Digest before then.

1.46 NEW SECURITY ISSUES U.S. Corporations

Millions of dollars

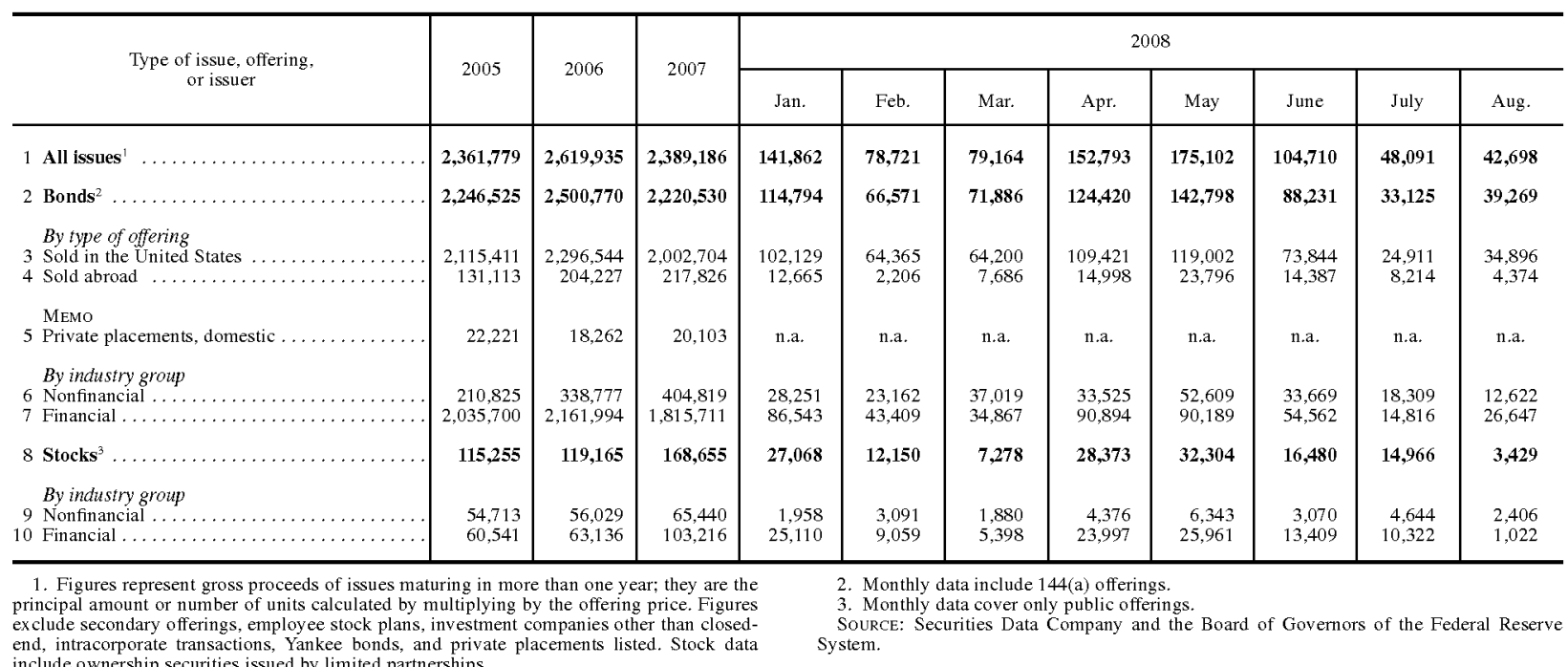

end, intracorporate transactions, Yankee bonds, and private placements listed Stock dat

include ownership securities issued by limited partnerships. 
1.47 OPEN-END INVESTMENT COMPANIES Net Sales and Assets ${ }^{1}$ Millions of dollars

\begin{tabular}{|c|c|c|c|c|c|c|c|c|c|c|}
\hline \multirow{2}{*}{ Item } & \multirow{2}{*}{2006} & \multirow{2}{*}{$2007^{r}$} & \multicolumn{8}{|c|}{2008} \\
\hline & & & Mar. & Apr. & May & June & July & Aug. & Sept. ${ }^{r}$ & oct. \\
\hline 1 Sales of own shares ${ }^{2}$ & $2,009,480$ & $2,530,131$ & 200,928 & 229,537 & 205,830 & 189,241 & 193,122 & 165,304 & 203,056 & 239,719 \\
\hline $\begin{array}{l}2 \text { Redemptions of own shares } \\
3 \text { Net sales }{ }^{3} \ldots \ldots \ldots \ldots . .\end{array}$ & $\begin{array}{r}1,782,393 \\
227,087\end{array}$ & $\begin{array}{r}2,306,301 \\
223,830\end{array}$ & $\begin{array}{r}201,377 \\
-449\end{array}$ & $\begin{array}{r}198,284 \\
31,253\end{array}$ & $\begin{array}{r}169,775 \\
36,055\end{array}$ & $\begin{array}{r}188,805 \\
436\end{array}$ & $\begin{array}{r}220,070 \\
-26,948\end{array}$ & $\begin{array}{r}177,441 \\
-12,137\end{array}$ & $\begin{array}{r}266,872 \\
-63,816\end{array}$ & $\begin{array}{r}366,566 \\
-126,847\end{array}$ \\
\hline 4 Assets $^{4}$ & $8,058,059$ & $8,914,249$ & $8,263,656$ & $8,634,205$ & $\mathbf{8 , 8 1 4 , 7 9 7}$ & $8,276,887$ & $\mathbf{8 , 1 0 0 , 8 2 1}$ & $8,069,019$ & $7,245,214$ & $6,009,443$ \\
\hline $\begin{array}{l}5 \text { Cash }^{5} \ldots \ldots \ldots \ldots \ldots \ldots \\
6 \text { Other } \ldots \ldots \ldots \ldots \ldots\end{array}$ & $\begin{array}{r}345,066 \\
7,712,993\end{array}$ & $\begin{array}{r}378,795 \\
8,535,454\end{array}$ & $\begin{array}{r}383,612 \\
7,880,044\end{array}$ & $\begin{array}{r}421,223 \\
8,212,982\end{array}$ & $\begin{array}{r}429,119 \\
8,385,678\end{array}$ & $\begin{array}{r}408,324 \\
7,868,563\end{array}$ & $\begin{array}{r}376,820 \\
7,724,001\end{array}$ & $\begin{array}{r}388,145 \\
7,680,874\end{array}$ & $\begin{array}{r}357,900 \\
6,887,314\end{array}$ & $\begin{array}{r}311,104 \\
5,698,339\end{array}$ \\
\hline
\end{tabular}

1. Data include stock, hybrid, and bond mutual funds and exclude money market mutual funds.

2. Excludes reinvestment of net income dividends and capital gains distributions and share issue of conversions from one fund to another in the same group.

3. Excludes sales and redemptions resulting from transfers of shares into or out of money market mutual funds within the same fund family.
4. Market value at end of period, less current liabilities.

5. Includes all U.S. Treasury securities and other short-term debt securities.

SoURCE: Investment Company Institute. Data based on reports of membership, which comprises substantially all open-end investment companies registered with the Securities and Exchange Commission. Data reflect underwritings of newly formed companies after their initial offering of securities

\subsection{DOMESTIC FINANCE COMPANIES Assets and Liabilities}

Billions of dollars, end of period; not seasonally adjusted

\begin{tabular}{|c|c|c|c|c|c|c|c|c|c|c|}
\hline \multirow{2}{*}{ Account } & \multirow{2}{*}{2005} & \multirow{2}{*}{$2006^{r}$} & \multirow{2}{*}{$2007^{r}$} & \multicolumn{4}{|c|}{2007} & \multicolumn{3}{|c|}{2008} \\
\hline & & & & $\mathrm{Q}^{1^{\mathrm{r}}}$ & $\mathrm{Q}^{\mathrm{r}}$ & $\mathrm{Q3}^{r}$ & Q4 & $\mathrm{Q} 1^{\mathrm{r}}$ & $\mathrm{Q}^{\mathrm{r}}$ & Q3 \\
\hline ASSETS & & & & & & & & & & \\
\hline 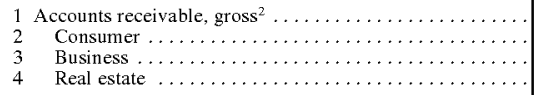 & $\begin{array}{r}1,622.4 \\
601.8 \\
479.2 \\
541.4\end{array}$ & $\begin{array}{r}1,732.7 \\
640.3 \\
498.0 \\
594.4\end{array}$ & $\begin{array}{r}1,761.7 \\
707.0 \\
522.9 \\
531.9\end{array}$ & $\begin{array}{r}1,727.9 \\
642.7 \\
505.4 \\
579.8\end{array}$ & $\begin{array}{r}1,731.3 \\
659.0 \\
509.2 \\
563.2\end{array}$ & $\begin{array}{r}1,756.3 \\
688.1 \\
507.8 \\
560.4\end{array}$ & $\begin{array}{r}1,761.7 \\
707.0 \\
522.9 \\
531.9\end{array}$ & $\begin{array}{r}1,773.4 \\
705.6 \\
541.9 \\
525.8\end{array}$ & $\begin{array}{r}1,759.2 \\
703.7 \\
563.9 \\
491.6\end{array}$ & $\begin{array}{r}1,740.4 \\
714.8 \\
557.0 \\
468.6\end{array}$ \\
\hline $\begin{array}{ll}5 \text { LEss: } & \text { Reserves for unearned income } \ldots \ldots \ldots \ldots \ldots \ldots \ldots \ldots \ldots \ldots \ldots \ldots \ldots \\
6 \text { LEss: } & \text { Reserves for losses } \ldots \ldots \ldots \ldots \ldots \ldots \ldots\end{array}$ & 44.7 & $\begin{array}{l}49.2 \\
26.6\end{array}$ & $\begin{array}{l}50.1 \\
33.6\end{array}$ & $\begin{array}{l}50.7 \\
25.5\end{array}$ & $\begin{array}{l}50.6 \\
25.5\end{array}$ & $\begin{array}{l}50.2 \\
28.6\end{array}$ & $\begin{array}{l}50.1 \\
33.6\end{array}$ & $\begin{array}{l}51.3 \\
34.7\end{array}$ & $\begin{array}{l}49.3 \\
36.3\end{array}$ & $\begin{array}{l}48.7 \\
41.0\end{array}$ \\
\hline $\begin{array}{l}7 \text { Accounts receivable, net } \ldots \ldots \ldots \ldots \ldots \ldots \ldots \ldots \ldots \ldots \ldots \ldots \ldots \ldots \ldots \ldots \ldots \ldots \ldots \ldots \ldots \ldots \ldots \ldots \ldots \ldots \ldots \\
8 \text { All other } \ldots \ldots \ldots \ldots\end{array}$ & $\begin{array}{r}1,553.2 \\
535.7\end{array}$ & $\begin{array}{r}1,656.8 \\
486.4\end{array}$ & $\begin{array}{r}1,678.0 \\
498.3\end{array}$ & $\begin{array}{r}1,651.6 \\
497.7\end{array}$ & $\begin{array}{r}1,655.2 \\
505.2\end{array}$ & $\begin{array}{r}1.677 .5 \\
515.7\end{array}$ & $\begin{array}{r}1,678.0 \\
498.3\end{array}$ & $\begin{array}{r}1,687.4 \\
522.0\end{array}$ & $\begin{array}{r}1,673.6 \\
520.4\end{array}$ & $\begin{array}{r}1,650.6 \\
513.5\end{array}$ \\
\hline 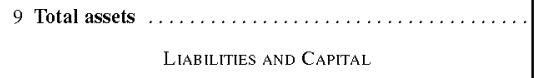 & $2,088.8$ & $2,143.3$ & $2,176.3$ & $2,149.4$ & $2,160.4$ & $2,193.2$ & $2,176.3$ & $2,209.4$ & $2,194.1$ & $2,164.1$ \\
\hline $\begin{array}{l}10 \text { Bank loans } \ldots \ldots \ldots \ldots \ldots \ldots \ldots \ldots \ldots \ldots \ldots \ldots \ldots \ldots \ldots \ldots \ldots \ldots \ldots \ldots \ldots \ldots \ldots \ldots \ldots \ldots \ldots \\
11 \text { Commercial paper } \ldots \ldots \ldots \ldots \ldots \ldots\end{array}$ & $\begin{array}{l}142.1 \\
160.0\end{array}$ & $\begin{array}{l}129.2 \\
165.3\end{array}$ & $\begin{array}{l}182.0 \\
123.5\end{array}$ & $\begin{array}{l}138.1 \\
132.5\end{array}$ & $\begin{array}{l}153.5 \\
127.0\end{array}$ & $\begin{array}{l}176.7 \\
119.8\end{array}$ & $\begin{array}{l}182.0 \\
123.5\end{array}$ & $\begin{array}{l}183.4 \\
113.5\end{array}$ & $\begin{array}{l}197.6 \\
112.4\end{array}$ & 169.2 \\
\hline 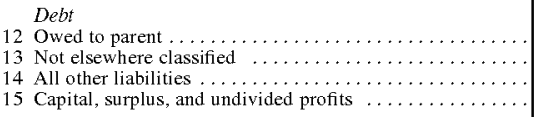 & $\begin{array}{l}312.2 \\
806.5 \\
423.6 \\
244.4\end{array}$ & $\begin{array}{l}338.5 \\
849.7 \\
424.2 \\
236.4\end{array}$ & $\begin{array}{l}321.4 \\
974.1 \\
387.7 \\
187.6\end{array}$ & $\begin{array}{l}327.0 \\
963.6 \\
387.4 \\
200.8\end{array}$ & $\begin{array}{l}344.4 \\
959.8 \\
385.1 \\
190.6\end{array}$ & $\begin{array}{l}327.8 \\
983.9 \\
392.4 \\
192.7\end{array}$ & $\begin{array}{l}321.4 \\
974.1 \\
387.7 \\
187.6\end{array}$ & $\begin{array}{r}328.7 \\
1,004.5 \\
391.7 \\
187.6\end{array}$ & $\begin{array}{l}319.9 \\
989.3 \\
391.5 \\
183.4\end{array}$ & $\begin{array}{l}326.9 \\
986.7 \\
392.4 \\
185.7\end{array}$ \\
\hline 16 Total liabilities and capital & $2,088.8$ & $2,143.3$ & $2,176.3$ & $2,149.4$ & $2,160.4$ & $2,193.2$ & $2,176.3$ & $2,209.4$ & $2,194.1$ & $2,164.1$ \\
\hline
\end{tabular}

NotE: Some of the data presented in the table is available in the Board's monthly G.20

422) statistical release, which is available at www.federalreserve.gov/releases.
1. Includes finance company subsidiaries of bank holding companies but not of retailers and banks. Data are amounts carried on the balance sheets of finance companies; securitized pools are not shown, as they are not on the books. 
1.52 DOMESTIC FINANCE COMPANIES Owned and Managed Receivables ${ }^{1}$

Billions of dollars, amounts outstanding

\begin{tabular}{|c|c|c|c|c|c|c|c|c|c|c|}
\hline & \multirow{2}{*}{ Type of credit } & \multirow{2}{*}{2005} & \multirow{2}{*}{2006} & \multirow{2}{*}{2007} & \multicolumn{6}{|c|}{2008} \\
\hline & & & & & Apr. & May & June & July ${ }^{r}$ & Aug. & Sept. \\
\hline & \multirow[b]{2}{*}{ Total } & \multicolumn{9}{|c|}{ Seasonally adjusted } \\
\hline 1 & & $1,895.4$ & $2,009.8$ & $2,049 \cdot 1^{\mathrm{r}}$ & $2,067.5^{r}$ & $2,063.6^{r}$ & $2,045.2^{\mathrm{r}}$ & $2,047.8$ & $2,033.0$ & $2,017.2$ \\
\hline 2 & Consumer & 775.2 & 819.4 & 887.4 & 891.2 & 891.2 & 885.9 & 886.1 & 881.0 & 876.0 \\
\hline 3 & Real estate & 560.4 & 609.9 & $569.0^{r}$ & $562.0^{r}$ & $552.1^{\mathrm{r}}$ & $529.3^{r}$ & 523.4 & 512.0 & 507.8 \\
\hline & 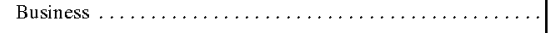 & 559.7 & 580.6 & 592.7 & 614.3 & 620.3 & 630.0 & 638.3 & 640.0 & 633.4 \\
\hline & & \multicolumn{9}{|c|}{ Not seasonally adjusted } \\
\hline \multicolumn{2}{|c|}{5 Total } & $1,910.9$ & $2,026.2$ & $2,065.8^{\mathrm{r}}$ & $2,065.0^{r}$ & $2,063.8^{r}$ & $2,044.5^{r}$ & $2,036.4$ & $2,024.7$ & $2,012.8$ \\
\hline 6 & Consumer & 781.4 & 825.4 & 893.5 & 884.2 & 884.4 & 880.4 & 883.7 & 883.0 & 881.6 \\
\hline 7 & Motor vehicle loans & 278.0 & 259.8 & $261.5^{r}$ & $255.1^{r}$ & $254.1^{r}$ & $250.2 r$ & 252.6 & 256.6 & 258.5 \\
\hline 8 & Motor vehicle leases .. & 85.3 & 106.0 & 122.9 & 125.5 & 125.3 & 121.9 & 122.1 & 120.8 & 118.5 \\
\hline 9 & Revolving $^{2} \ldots \ldots \ldots \ldots \ldots \ldots \ldots \ldots \ldots \ldots \ldots$ & 66.3 & 79.9 & 86.0 & 83.1 & 83.9 & 84.0 & 83.9 & 83.6 & 83.3 \\
\hline 10 & & 172.3 & 194.7 & $236.5^{r}$ & 245.7 & 246.5 & 247.6 & 250.1 & 252.2 & 254.4 \\
\hline \multicolumn{11}{|c|}{ Securitized assets ${ }^{4}$} \\
\hline 11 & Motor vehicle loans & 112.6 & 112.8 & $110.7^{\mathrm{r}}$ & $98.1^{r}$ & $98.3^{r}$ & $101.0^{r}$ & 99.2 & 93.8 & 90.7 \\
\hline 12 & Motor vehicle leases & 4.2 & 3.6 & 3.1 & 3.0 & 2.9 & 2.9 & 2.9 & 2.8 & 2.8 \\
\hline 13 & Revolving .......... & 14.9 & 15.9 & 25.6 & 25.1 & 24.8 & 24.5 & 24.5 & 24.6 & 24.7 \\
\hline 14 & Other $\ldots \ldots \ldots \ldots$. & 47.8 & 52.8 & 44.7 & 43.2 & 42.9 & 42.4 & 41.9 & 41.4 & 41.0 \\
\hline 15 & Real estate $\ldots \ldots \ldots \ldots \ldots \ldots \ldots \ldots \ldots \ldots \ldots \ldots$ & 565.0 & 614.8 & $573.8^{r}$ & $560.1^{r}$ & $552.4^{r}$ & $528.3^{r}$ & 522.4 & 511.2 & 504.9 \\
\hline 16 & One- to four-family $\ldots \ldots \ldots \ldots \ldots \ldots \ldots \ldots \ldots$ & 489.8 & 538.1 & 474.2 & 451.9 & 442.6 & 420.4 & 414.3 & 402.0 & 395.2 \\
\hline \multirow{2}{*}{\multicolumn{11}{|c|}{$\begin{array}{l}\text { Other } \ldots \ldots \ldots \ldots \ldots \ldots \ldots \ldots \ldots \ldots \\
\text { Securitized real estate assets }^{4}\end{array}$}} \\
\hline & & & & & & & & & & \\
\hline 18 & One- to four-family $\ldots \ldots \ldots \ldots \ldots \ldots \ldots \ldots$ & 18.9 & 16.8 & $34.9^{r}$ & 34.5 & 34.4 & 31.4 & 31.3 & 31.3 & 31.2 \\
\hline 19 & 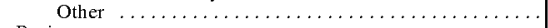 & 4.8 & 3.7 & $5.6^{r}$ & $5.4 r$ & 5.4 & 5.4 & 5.3 & 5.3 & 5.2 \\
\hline 20 & Business $\ldots \ldots \ldots \ldots \ldots \ldots \ldots \ldots \ldots \ldots \ldots \ldots \ldots$ & 564.5 & 586.0 & 598.6 & 620.7 & 627.0 & 635.7 & 630.3 & 630.5 & 626.2 \\
\hline 21 & Motor vehicles $\ldots \ldots \ldots \ldots \ldots \ldots \ldots \ldots \ldots \ldots \ldots \ldots$ & 105.5 & 105.1 & 105.7 & 108.5 & 110.0 & 112.8 & 108.3 & 101.4 & 97.3 \\
\hline 22 & Retail loans & 15.2 & 17.1 & 16.4 & 15.1 & 14.8 & 14.7 & 14.5 & 14.4 & 14.1 \\
\hline 23 & $\ldots \ldots \ldots \ldots \ldots \ldots \ldots \ldots$ & 61.2 & 55.7 & 56.9 & 61.6 & 63.4 & 64.5 & 60.2 & 53.3 & 52.4 \\
\hline 24 & Leases ............ & 29.0 & 32.3 & 32.4 & 31.8 & 31.8 & 33.6 & 33.6 & 33.7 & 30.8 \\
\hline 25 & Equipment $\ldots \ldots \ldots \ldots \ldots \ldots \ldots \ldots \ldots \ldots \ldots$ & 281.9 & 299.5 & 319.4 & 334.6 & 342.0 & 347.2 & 349.6 & 354.5 & 356.6 \\
\hline 26 & 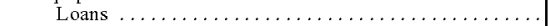 & 93.6 & 102.4 & 106.1 & 114.6 & 114.8 & 113.5 & 115.3 & 118.2 & 119.0 \\
\hline 27 & Leases............ & 188.3 & 197.1 & 213.3 & 220.0 & 227.2 & 233.7 & 234.3 & 236.4 & 237.5 \\
\hline 28 & Other business receivables ${ }^{6}$ & 91.8 & 93.5 & 94.4 & 102.8 & 103.1 & 103.9 & 103.5 & 102.5 & 103.2 \\
\hline \multicolumn{11}{|c|}{ Securitized assets ${ }^{4}$} \\
\hline 29 & Motor vehicles & 28.8 & 38.0 & 33.6 & 28.4 & 24.7 & 23.6 & 22.1 & 27.5 & 26.1 \\
\hline 30 & Retail loans & 2.7 & 3.0 & 2.6 & 2.6 & 2.5 & 2.5 & 2.5 & 2.5 & 2.4 \\
\hline 31 & 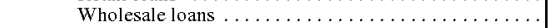 & 26.0 & 34.9 & 30.9 & 25.8 & 22.1 & 21.1 & 19.6 & 25.0 & 23.7 \\
\hline 32 & Leases $\ldots \ldots \ldots \ldots \ldots \ldots \ldots \ldots \ldots \ldots$ & .1 & .1 & .1 & .1 & .1 & .1 & .0 & .0 & .0 \\
\hline 33 & Equipment $\ldots \ldots \ldots \ldots \ldots \ldots \ldots \ldots \ldots \ldots \ldots \ldots$ & 24.4 & 15.4 & 13.1 & 13.8 & 13.7 & 13.7 & 13.2 & 11.9 & 11.6 \\
\hline 34 & 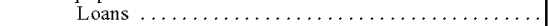 & 11.6 & 9.9 & 9.2 & 9.7 & 9.6 & 9.5 & 9.1 & 7.9 & 7.6 \\
\hline 35 & $\ldots \ldots \ldots \ldots \ldots \ldots \ldots$ & 12.8 & 5.5 & 3.9 & 4.1 & 4.1 & 4.2 & 4.1 & 4.0 & 3.9 \\
\hline 36 & Other business receivables ${ }^{6} \ldots \ldots \ldots$. & 32.2 & 34.6 & 32.4 & 32.6 & 33.5 & 34.5 & 33.5 & 32.6 & 31.4 \\
\hline
\end{tabular}

NOTE: This table has been revised to incorporate several changes resulting from the benchmarking of finance company receivables to the June 1996 Survey of Finance Companies. In that benchmark survey, and in the monthly surveys that have followed, more-detailed breakdowns have been obtained for some components. In addition, previously unavailable data on securitized real estate loans are now included in this table. The new information has resulted in some reclassification of receivables among the three major categories (consumer, real estate, and business) and in discontinuities in some component series between May and June 1996.

Includes finance company subsidiaries of bank holding companies but not of retailers and banks. Data in this table also appear in the Board's G.20 (422) monthly statistical release, available at www.federalreserve.gov/releases.

1. Owned receivables are those carried on the balance sheet of the institution. Managed receivables are outstanding balances of pools upon which securities have been issued; these balances are no longer carried on the balance sheets of the loan originator. Data are shown

before deductions for unearned income and losses. Components may not sum to totals because of rounding.

2. Excludes revolving credit reported as held by depository institutions that are subsidiaries of finance companies.

3. Includes personal cash loans, mobile home loans, and loans to purchase other types of consumer goods, such as appliances, apparel, boats, and recreation vehicles.

4. Outstanding balances of pools upon which securities have been issued; these balances are no longer carried on the balance sheets of the loan originator.

5. Credit arising from transactions between manufacturers and dealers--that is, floor plan financing.

6. Includes loans on commercial accounts receivable, factored commercial accounts, and receivable dealer capital; small loans used primarily for business or farm purposes; and wholesale and lease paper for mobile homes, campers, and travel trailers. 
1.53 MORTGAGE MARKETS Mortgages on New Homes

Millions of dollars except as noted

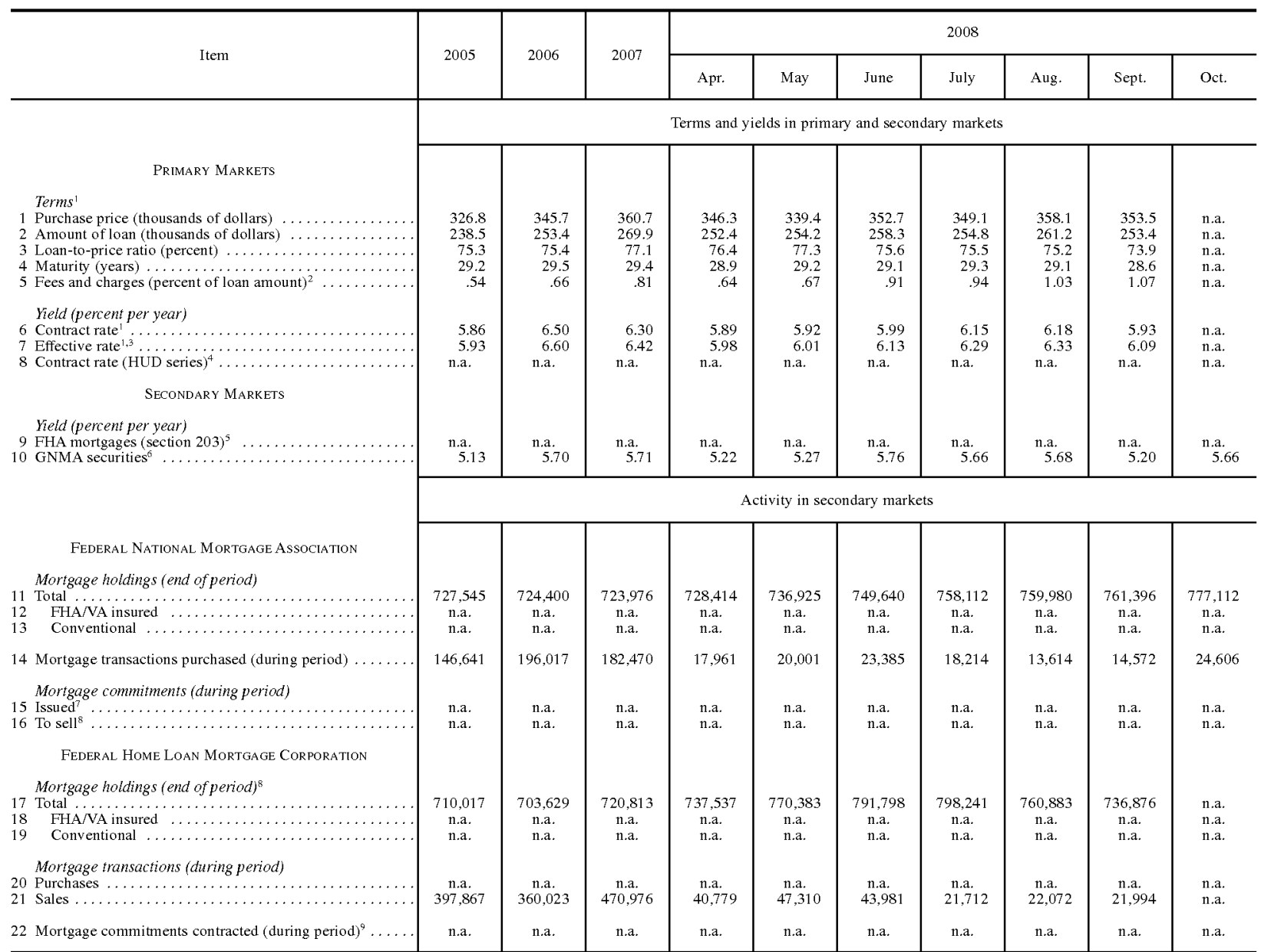

1. Weighted averages based on sample surveys of mortgages originated by major institutional lender groups for purchase of newly built homes; compiled by the Federal Housing Finance Board in cooperation with the Federal Deposit Insurance Corporation.

2. Includes all fees, commissions, discounts, and "points" paid (by the borrower or the seller) to obtain a loan.

3. Average effective interest rate on loans closed for purchase of newly built homes, assuming prepayment at the end of ten years.

4. Average contract rate on new commitments for conventional first mortgages; from U.S. Department of Housing and Urban Development (HUD). Based on transactions on the first day of the subsequent month.

5. Average gross yield on thirty-year, minimum-downpayment first mortgages insured by the Federal Housing Administration (FHA) for immediate delivery in the private secondary market. Based on transactions on first day of subsequent month.
6. Average net yields to investors on fully modified pass-through securities backed by mortgages and guaranteed by the Government National Mortgage Association (GNMA) assuming prepayment in twelve years on pools of thirty-year mortgages insured by the Federal Housing Administration or guaranteed by the Department of Veterans Affairs. 7. Does not include standby commitments issued but includes standby commitments converted.

8. Includes participation loans as well as whole loans.

9. Includes conventional and government-underwritten loans. The Federal Home Loan Mortgage Corporation's mortgage commitments and mortgage transactions include activity under mortgage securities swap programs, whereas the corresponding data for the Federal National Mortgage Association exclude swap activity. 


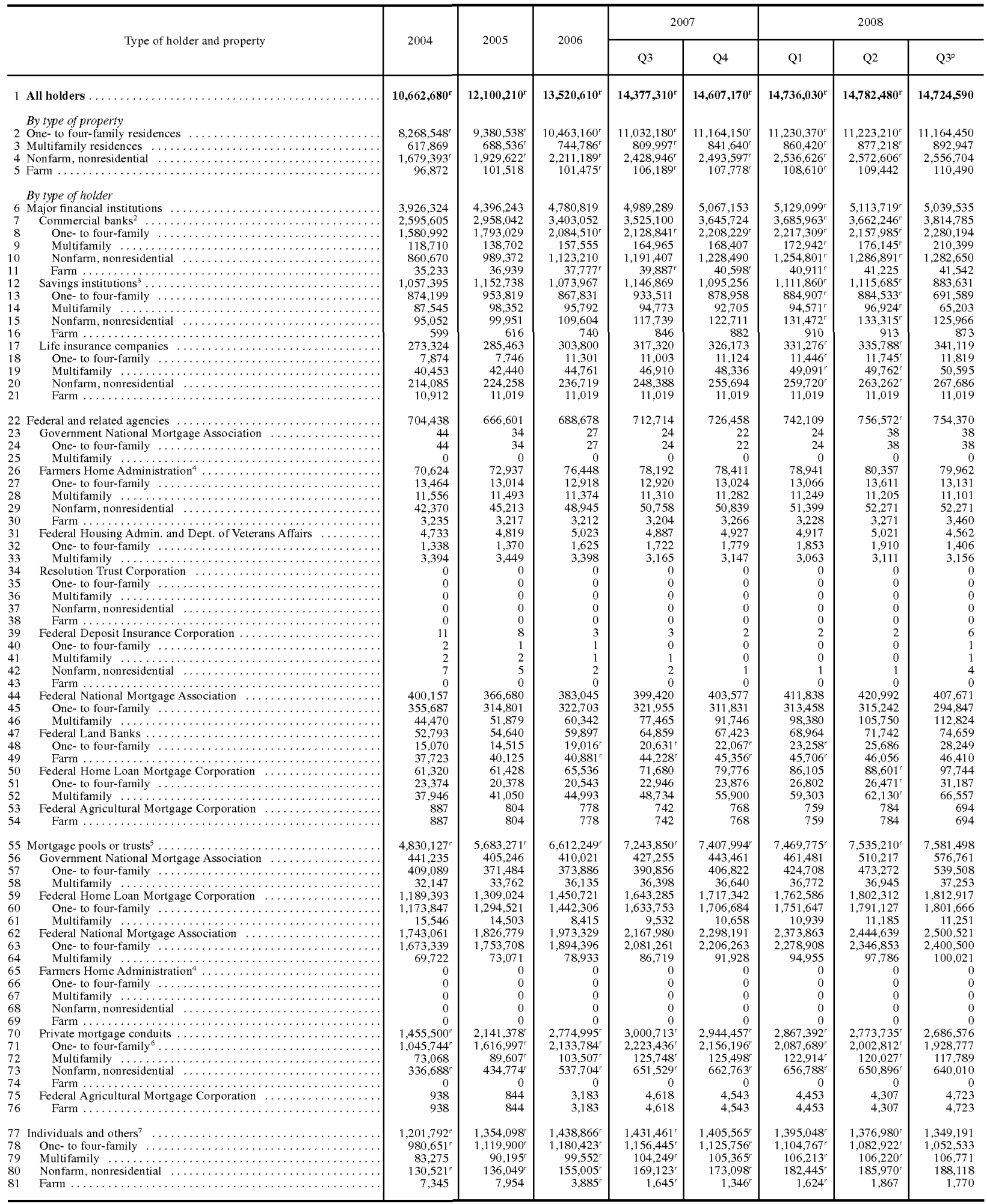

1. Multifamily debt refers to loans on structures of five or more units. 2. Includes loans held by nondeposit trust companies but not loans held by bank trust departments.

. Includes savings banks and savings and loan associations.

4. FmHA-guaranteed securities sold to the Federal Financing Bank were reallocated from FmHA mortgage pools to FmHA mortgage holdings in 1986:Q4 because of accounting changes by the Farmers Home Administration.

5. Outstanding principal balances of mortgage-backed securities insured or guaranteed by the agency indicated.
6. Includes securitized home equity loans.

7. Other holders include mortgage companies, real estate investment trusts, state and local credit agencies, state and local retirement funds, noninsured pension funds, credit unions, and

SouRCE: Based on data from yarious institutional and government sources. Separation of nonfarm mortgage debt by type of property, if not reported directly, and interpolations and extrapolations, when required for some quarters, are estimated in part by the Federal Reserve. Line 70 from LoanPerformance Corporation and other sources. 
1.55 TOTAL OUTSTANDING CONSUMER CREDIT ${ }^{1}$

Millions of dollars, amounts outstanding, end of period

\begin{tabular}{|c|c|c|c|c|c|c|c|c|c|c|}
\hline \multirow{2}{*}{\multicolumn{2}{|c|}{ Holder and type of credit }} & \multirow{2}{*}{2005} & \multirow{2}{*}{2006} & \multirow{2}{*}{2007} & \multicolumn{6}{|c|}{2008} \\
\hline & & & & & May $^{r}$ & Juner & July ${ }^{r}$ & Aug. ${ }^{r}$ & Sept.' & Oct. \\
\hline & & \multicolumn{9}{|c|}{ Seasonally adjusted } \\
\hline 1 & Total . . . . . . . . . . . . . . . . . & $2,285,160$ & $2,387,691$ & $2,519,020^{\mathrm{r}}$ & $2,565,446$ & $2,574,033$ & $2,581,360$ & $2,574,925$ & $2,581,656$ & $2,578,121$ \\
\hline \multirow{3}{*}{\multicolumn{2}{|c|}{$\begin{array}{l}2 \text { Revolving ....... } \\
3 \text { Nonrevolving }\end{array}$}} & 824,469 & 874,621 & $939,515^{r}$ & 962,935 & 965,673 & 971,776 & 973,773 & 976,255 & 976,073 \\
\hline & & $1,460,691$ & $1,513,070$ & $1,579,505$ & $1,602,511$ & $1,608,361$ & $1,609,584$ & $1,601,152$ & $1,605,401$ & $1,602,047$ \\
\hline & & \multicolumn{9}{|c|}{ Not seasonally adjusted } \\
\hline 4 & Total & $2,313,862$ & $2,418,262$ & $2,551,895^{r}$ & $2,547,640$ & $2,555,818$ & $2,566,264$ & $2,580,926$ & $2,590,451$ & $2,583,440$ \\
\hline & By major holder & & & & & & & & & \\
\hline & Commercial banks & 707,039 & 741,200 & 804,096 & 807,860 & 812,984 & 820,321 & 832,952 & 844,105 & 846,586 \\
\hline & Finance companies & 516,534 & 534,354 & 584,056 & 584,492 & 581,773 & 586,524 & 592,376 & 596,257 & 593,293 \\
\hline & Credit unions .... & 228,588 & 234,532 & 235,700 & 231,734 & 231,083 & 233,863 & 235,992 & 236,874 & 237,518 \\
\hline & Federal government and Sallie Mae & 89,822 & 91,676 & 98,396 & 104,195 & 104,566 & 105,280 & 106,489 & 106,896 & 108,371 \\
\hline & Savings institutions $\ldots \ldots \ldots \ldots \ldots$ & 109,077 & 95,547 & 90,787 & 89,183 & 90,003 & 89,216 & 88,429 & 77,775 & 78,670 \\
\hline 10 & Nonfinancial business .... & 58,817 & 56,757 & 55,184 & 51,270 & 51,338 & 51,526 & 51,989 & 51,923 & 52,053 \\
\hline & Pools of securitized assets ${ }^{3}$ & 603,986 & 664,197 & $683,677^{r}$ & 678,906 & 684,071 & 679,535 & 672,699 & 676,621 & 666,950 \\
\hline \multicolumn{11}{|c|}{ By major type of credit $t^{4}$} \\
\hline 12 & Revolving ........ & 849,975 & 902,316 & $969,597^{r}$ & 953,675 & 959,348 & 965,152 & 973,339 & 975,335 & 973,966 \\
\hline 13 & Commercial banks . & 311,204 & 327,302 & 353,446 & 325,992 & 328,882 & 335,636 & 343,747 & 356,332 & 363,122 \\
\hline 14 & Finance companies . & 66,307 & 79,874 & 86,046 & 83,898 & 84,035 & 83,856 & 83,627 & 83,310 & 82,346 \\
\hline 15 & Credit unions ..... & 24,688 & 27,388 & 31,071 & 30,752 & 31,275 & 31,600 & 31,987 & 32,109 & 32,047 \\
\hline 16 & Federal government and Sallie Mae & n.a. & na. & n.a. & n.a. & n.a. & n.a. & n.a. & n.a. & n.a. \\
\hline 17 & Savings institutions $\ldots \ldots \ldots \ldots$ & 40,755 & 42,459 & 44,750 & 44,844 & 45,863 & 45,898 & 45,934 & 36,076 & 36,870 \\
\hline 18 & Nonfinancial business & 11,598 & 7,779 & 4,245 & 3,709 & 3,749 & 3,745 & 3,827 & 3,821 & 3,805 \\
\hline & Pools of securitized assets ${ }^{3}$ & 395,423 & 417,514 & $450,040^{r}$ & 464,479 & 465,544 & 464,416 & 464,215 & 463,687 & 455,775 \\
\hline 20 & Nonrevolving & $1,463,887$ & $1,515,946$ & $1,582,298^{\circ}$ & $1,593,965$ & $1,596,470$ & $1,601,112$ & $1,607,587$ & $1,615,117$ & $1,609,474$ \\
\hline 21 & Commercial banks & 395,835 & 413,898 & 450,650 & 481,868 & 484,102 & 484,685 & 489,205 & 487,773 & 483,464 \\
\hline 22 & Finance companies & 450,226 & 454,480 & $498,010^{r}$ & 500,595 & 497,737 & 502,667 & 508,748 & 512,946 & 510,946 \\
\hline 23 & Credit unions .... & 203,900 & 207,144 & 204,629 & 200,982 & 199,808 & 202,263 & 204,005 & 204,765 & 205,471 \\
\hline 24 & Federal government and Sallie Mae & 89,822 & 91,676 & 98,396 & 104,195 & 104,566 & 105,280 & 106,489 & 106,896 & 108,371 \\
\hline 25 & Savings institutions $\ldots \ldots \ldots \ldots \ldots \ldots$ & 68,322 & 53,088 & 46,037 & 44,338 & 44,140 & 43,317 & 42,495 & 41,699 & 41,800 \\
\hline 26 & Nonfinancial business $\ldots \ldots \ldots \ldots \ldots$ & 47,219 & 48,978 & 50,939 & 47,561 & 47,589 & 47,781 & 48,161 & 48,102 & 48,248 \\
\hline & Pools of securitized assets ${ }^{3}$ & 208,564 & 246,683 & $233,637^{r}$ & 214,427 & 218,527 & 215,118 & 208,484 & 212,934 & 211,175 \\
\hline
\end{tabular}

1. The Board's series on amounts of credit covers most short- and intermediate-term credit extended to individuals, excluding loans secured by real estate. Data in this table also appear in the Board's G.19 (421) monthly statistical release, available at www.federalreserve.gov' releases.

2. Comprises motor vehicle loans, mobile home loans, and all other loans that are not included in revolving credit, such as loans for education, boats, trailers, or vacations. These loans may be secured or unsecured.

\subsection{TERMS OF CONSUMER CREDIT ${ }^{1}$}

Percent per year except as noted

\begin{tabular}{|c|c|c|c|c|c|c|c|c|c|c|c|}
\hline \multirow{2}{*}{\multicolumn{2}{|c|}{ Item }} & \multirow{2}{*}{2005} & \multirow{2}{*}{2006} & \multirow{2}{*}{2007} & \multicolumn{7}{|c|}{2008} \\
\hline & & & & & Apr. & May & June & July & Aug. & Sept. & Oct. \\
\hline \multicolumn{12}{|c|}{ INTEREST RATES } \\
\hline \multicolumn{12}{|c|}{ Commercial banks ${ }^{2}$} \\
\hline & 48-month new car & 7.08 & 7.72 & 7.77 & n.a. & 6.84 & n.a. & n.a. & 6.95 & n.a. & n.a. \\
\hline & 24-month personal $\ldots \ldots \ldots \ldots \ldots \ldots \ldots$ & 12.05 & 12.41 & 12.39 & n.a. & 11.14 & n.a. & n.a. & 11.43 & n.a. & n.a. \\
\hline \multicolumn{12}{|c|}{ Credit card plan } \\
\hline & All accounts ... & 12.51 & 13.21 & 13.38 & n.a. & 11.87 & n.a. & n.a. & 11.93 & na. & n.a. \\
\hline & Accounts assessed interest & 14.55 & 14.73 & 14.67 & n.a. & 13.48 & n.a. & n.a. & 13.64 & n.a. & n.a. \\
\hline \multicolumn{12}{|c|}{ Auto finance companies } \\
\hline & New car $\ldots \ldots \ldots \ldots$ & 6.02 & 4.99 & 4.87 & 4.54 & 5.82 & 5.49 & 3.28 & 5.11 & 6.24 & 6.41 \\
\hline 6 & Used car ..... & 8.81 & 9.61 & 9.24 & 8.34 & 8.23 & 8.36 & 8.43 & 8.42 & 8.46 & 8.52 \\
\hline \multicolumn{12}{|c|}{ OTHER TERMS ${ }^{3}$} \\
\hline \multicolumn{12}{|c|}{ Maturity (months) } \\
\hline & New car ........ & 60.0 & 63.0 & 62.0 & 63.1 & 64.0 & 63.5 & 67.2 & 64.6 & 64.3 & 63.9 \\
\hline & Used car $\ldots \ldots \ldots \ldots \ldots \ldots \ldots \ldots$ & 58.6 & 59.4 & 60.7 & 60.6 & 60.5 & 60.2 & 60.1 & 59.8 & 59.4 & n.a. \\
\hline & Loan-to-value ratio & & & & & & & & & & \\
\hline & New car $\ldots \ldots \ldots$ & 88 & 94 & 95 & 94 & 92 & 93 & 95 & 88 & 85 & 86 \\
\hline & Used car ......... & 98 & 99 & 100 & 96 & 97 & 97 & 96 & 97 & 98 & n.a. \\
\hline & Amount financed (dollars) & & & & & & & & & & \\
\hline & New car $\ldots \ldots \ldots \ldots$ & 24,133 & 26,620 & 28,287 & 27,397 & 24,579 & 24,505 & 27,582 & 26,920 & 25,427 & 25,391 \\
\hline & Used car . . . . . . . . . & 16,228 & 16,671 & 17,095 & 17,281 & 17,114 & 16,163 & 16,679 & 16,446 & 16,296 & n.a. \\
\hline
\end{tabular}

1. The Board's series on amounts of credit covers most short- and intermediate-term credit extended to individuals. Data in this table also appear in the Board's G.19 (421) monthly statistical release, available at www.federalreserve.gov/releases.

3. Outstanding balances of pools upon which securities have been issued; these balances are no longer carried on the balance sheets of the loan originator.

4. Totals include estimates for certain holders for which only consumer credit totals are available. 
1.57 FUNDS RAISED IN U.S. CREDIT MARKETS ${ }^{1}$

Billions of dollars; quarterly data at seasonally adjusted annual rates

\begin{tabular}{|c|c|c|c|c|c|c|c|c|c|c|c|c|c|}
\hline \multirow{2}{*}{\multicolumn{2}{|c|}{ Transaction category or sector }} & \multirow{2}{*}{2002} & \multirow{2}{*}{2003} & \multirow{2}{*}{2004} & \multirow{2}{*}{2005} & \multirow{2}{*}{2006} & \multicolumn{2}{|c|}{2006} & \multicolumn{4}{|c|}{2007} & \multirow{2}{*}{$\frac{2008}{\mathrm{Q} 1}$} \\
\hline & & & & & & & Q3 & Q4 & Q1 & Q2 & Q3 & Q4 & \\
\hline & & \multicolumn{12}{|c|}{ Nonfinancial sectors } \\
\hline & $\begin{array}{l}\text { Total net borrowing by domestic nonfinancial sectors .. } \\
\text { By instrument }\end{array}$ & $1,398.6$ & $1,667.7$ & $1,957.7$ & $2,247.3$ & $2,332.4$ & $2,029.5$ & $2,308.1$ & $2,307.5$ & $2,101.0$ & $2,742.5$ & $2,315.5$ & $2,036.3$ \\
\hline 2 & Commercial paper & -57.9 & -37.3 & 15.3 & -7.7 & 22.4 & -21.5 & 111.1 & 18.9 & 40.9 & -30.6 & 16.0 & 54.6 \\
\hline 3 & Treasury securities & 257.1 & 398.4 & 362.5 & 307.3 & 183.7 & 172.4 & 135.8 & 327.5 & -70.7 & 435.9 & 257.1 & 487.5 \\
\hline 4 & Agency-and GSE-backed securities & & -2.4 & -.6 & -.4 & -.3 & -1.0 & .5 & -1.3 & -.1 & -.8 & .7 & 1.3 \\
\hline 5 & Municipal securities and loans $\ldots \ldots \ldots \ldots \ldots \ldots \ldots$ & 159.4 & 137.6 & 130.5 & 195.0 & 177.3 & 169.2 & 252.8 & 249.1 & 246.7 & 165.5 & 198.7 & 152.8 \\
\hline 6 & 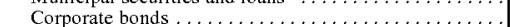 & 129.3 & 150.4 & 74.4 & 53.6 & 213.4 & 133.8 & 315.9 & 282.2 & 377.5 & 225.2 & 371.6 & 274.8 \\
\hline 7 & Bank loans n.e.c. & -106.6 & -77.0 & 10.8 & 137.6 & 173.4 & 163.1 & 223.2 & 85.2 & 92.3 & 420.1 & 397.9 & 257.7 \\
\hline 8 & Other loans and advances & 15.7 & 5.5 & 20.4 & 47.7 & 54.8 & -36.1 & 68.5 & 81.3 & 79.6 & 299.1 & 3.7 & 101.7 \\
\hline 9 & Mortgages ........... & 893.1 & 988.2 & $1,229.3$ & $1,419.8$ & $1,403.2$ & $1,330.0$ & $1,091.5$ & $1,149.4$ & $1,197.0$ & $1,026.1$ & 971.4 & 559.8 \\
\hline 10 & Home... & 758.6 & 798.9 & $1,028.1$ & $1,106.0$ & $1,072.3$ & $1,006.0$ & 730.9 & 846.0 & 784.8 & 577.2 & 618.5 & 313.0 \\
\hline 11 & Multifamily residential & 37.1 & 71.2 & 48.3 & 71.7 & 52.7 & 35.9 & 68.0 & 63.1 & 95.2 & 104.5 & 129.7 & 69.0 \\
\hline 12 & Commercial ........ & 90.5 & 119.4 & 150.2 & 237.5 & 270.7 & 280.5 & 285.0 & 231.9 & 308.6 & 335.8 & 214.7 & 174.5 \\
\hline 13 & Farm ....... & 6.9 & -1.3 & 2.7 & 4.6 & 7.5 & 7.6 & 7.6 & 8.3 & 8.4 & 8.5 & 8.5 & 3.3 \\
\hline 14 & Consumer credit & 107.9 & 104.4 & 115.0 & 94.5 & 104.4 & 119.7 & 108.9 & 115.1 & 137.7 & 202.1 & 98.5 & 146.1 \\
\hline & By borrowing sector & & & & & & & & & & & & \\
\hline 15 & Household ... & 832.9 & 981.0 & $1,064.0$ & $1,180.9$ & $1,196.9$ & $1,112.8$ & 937.9 & 905.4 & 942.8 & 856.2 & 829.9 & 481.0 \\
\hline 16 & Nonfinancial business & 164.2 & 170.4 & 416.6 & 587.9 & 800.9 & 598.1 & $1,015.8$ & 851.0 & $1,016.5$ & $1,312.7$ & $1,062.8$ & 927.0 \\
\hline 17 & Corporate ........ & 9.1 & 80.0 & 165.8 & 243.6 & 433.4 & 248.2 & 634.4 & 528.0 & 625.5 & 767.7 & 577.4 & 575.1 \\
\hline 18 & Nonfarm noncorporate & 148.0 & 92.1 & 244.7 & 331.6 & 349.1 & 336.1 & 358.8 & 297.4 & 379.9 & 532.4 & 461.2 & 321.5 \\
\hline 19 & Farm .............. & 7.1 & -1.6 & 6.1 & 12.7 & 18.4 & 13.9 & 22.6 & 25.6 & 11.1 & 12.6 & 24.2 & 30.4 \\
\hline 20 & State and local government & 143.9 & 120.3 & 115.3 & 171.6 & $\begin{array}{r}15.4 \\
151.2\end{array}$ & $\begin{array}{r}13.9 \\
147.2\end{array}$ & 218.2 & 224.9 & 212.4 & 138.5 & 164.8 & 139.5 \\
\hline 21 & Federal government ...... & 257.6 & 396.0 & 361.9 & 306.9 & 183.4 & 171.4 & 136.3 & 326.2 & -70.8 & 435.0 & 257.8 & 488.8 \\
\hline 22 & Foreign net borrowing in United States .. & 93.4 & 42.4 & 130.7 & 102.6 & 254.4 & 523.0 & 253.6 & 136.1 & 227.4 & 2.9 & 21.7 & 277.1 \\
\hline 23 & Commercial paper & 58.8 & 183 & 687 & 382 & 971 & 362.8 & 86 & -198 & 224 & -1938 & -78.3 & 2146 \\
\hline 24 & Bonds. & 31.6 & 28.7 & 61.8 & 54.5 & 150.9 & 180.2 & 218.0 & 174.8 & 167.3 & 173.2 & 56.1 & 39.8 \\
\hline 25 & Bank loans n.e.c. & 5.3 & -2.5 & 3.8 & 14.5 & 13.8 & -12.2 & 31.6 & -16.0 & 40.7 & 26.3 & 45.3 & 23.8 \\
\hline 26 & Other loans and advances & -2.3 & -2.1 & -3.6 & -4.6 & -7.4 & -7.7 & -4.6 & -3.0 & -2.9 & -2.9 & -1.3 & -1.1 \\
\hline \multirow[t]{2}{*}{27} & Total domestic plus foreign & $1,491.9$ & $1,710.1$ & $2,088.5$ & $\mathbf{2 , 3 4 9 . 9}$ & $2,586.8$ & $2,552.6$ & $2,561.7$ & $2,443.6$ & $2,328.4$ & $2,745.3$ & $2,337.2$ & $2,313.4$ \\
\hline & & \multicolumn{12}{|c|}{ Financial sectors } \\
\hline 28 & Total net borrowing by financial sectors ... & 870.3 & $1,060.8$ & 968.7 & $1,064.0$ & $1,287.7$ & 931.3 & $1,249.0$ & $1,264.2$ & $1,398.0$ & $2,348.0$ & $1,356.3$ & 801.7 \\
\hline & By inst & & & & & & & & & & & & \\
\hline 29 & Open market paper & -99.9 & -62.9 & 22.2 & 214.6 & 197.6 & 72.2 & 174.3 & 233.5 & 362.6 & -689.5 & -360.0 & -191.4 \\
\hline 30 & Government-sponsored enterprise securities & 219.8 & 250.9 & 75.0 & -84.0 & 35.6 & -83.5 & 40.7 & 66.7 & 161.4 & 556.6 & 344.8 & 119.9 \\
\hline 31 & Agency- and GSE-backed mortgage pool securities & 326.8 & 330.6 & 47.9 & 167.3 & 295.4 & 284.4 & 278.9 & 482.5 & 534.9 & 622.2 & 866.3 & 534.1 \\
\hline 32 & Corporate bonds . ...................... & 384.8 & 481.4 & 665.5 & 691.0 & 795.0 & 663.2 & 981.5 & 476.3 & 280.8 & 997.8 & 274.6 & -14.8 \\
\hline 33 & Bank loans n.e.c. ........ & 21.1 & 21.4 & 58.1 & 17.0 & -64.1 & -42.8 & -216.8 & 51.0 & 48.9 & 101.6 & 27.5 & 176.7 \\
\hline 34 & Other loans and advances & 6.8 & 31.2 & 74.1 & 44.4 & 21.2 & 29.9 & -3.9 & -30.5 & .4 & 746.2 & 187.0 & 156.4 \\
\hline 35 & 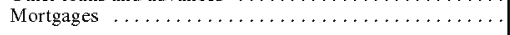 & 11.0 & 8.2 & 25.9 & 13.9 & 7.0 & 7.8 & -5.8 & -15.2 & 9.0 & 12.9 & 16.1 & 20.8 \\
\hline & By borrowing sector & & & & & & & & & & & & \\
\hline 36 & Commercial banking & 49.7 & 48.5 & 78.4 & 85.1 & 177.4 & 51.6 & 400.6 & 90.9 & 147.1 & 496.2 & 318.6 & 228.1 \\
\hline 37 & Savings institutions. & -23.4 & 34.5 & 89.0 & 23.8 & -111.9 & 17.1 & -463.3 & -20.7 & -24.6 & 363.5 & 71.1 & 67.0 \\
\hline 38 & Credit unions .......... & 2.0 & 2.2 & 2.3 & 3.3 & 4.2 & 2.0 & 8.4 & -10.5 & 10.6 & 37.9 & 15.7 & -15.2 \\
\hline 39 & Life insurance companies & 2.0 & 2.9 & 3.0 & 4 & 2.7 & 2.4 & 4.3 & 4.9 & 12.6 & 26.9 & 13.7 & 9.6 \\
\hline 40 & Government-sponsored enterprises & 219.8 & 250.9 & 75.0 & -84.0 & 35.6 & -83.5 & 40.7 & 66.7 & 161.4 & 556.6 & 344.8 & 119.9 \\
\hline 41 & Agency-and GSE-backed mortgage pools & 326.8 & 330.6 & 47.9 & 167.3 & 295.4 & 284.4 & 278.9 & 482.5 & 534.9 & 622.2 & 866.3 & 534.1 \\
\hline 42 & Issuers of asset-backed securities (ABSs) . & 212.3 & 244.2 & 427.3 & 669.2 & 772.0 & 701.1 & 910.9 & 428.8 & 472.8 & 97.7 & -285.2 & -305.0 \\
\hline 43 & Finance companies .......... & 66.2 & 111.1 & 134.3 & 33.5 & 34.8 & -36.6 & 69.0 & 13.9 & 9.3 & 122.1 & -45.6 & 73.9 \\
\hline 44 & Real estate investment trusts (REITs) & 27.3 & 31.5 & 98.3 & 59.8 & 41.1 & 32.8 & 14.0 & 2.2 & -21.2 & -14.7 & 10.4 & -40.3 \\
\hline 45 & Brokers and dealers ............. & -1.7 & 6.4 & 15.2 & 1 & 6.4 & 5.0 & -20.9 & 59.5 & 39.9 & -29.4 & -85.9 & 62.3 \\
\hline 46 & Funding corporations ........ & -10.7 & -1.9 & -2.2 & 105.6 & 29.9 & -44.9 & 6.4 & 146.0 & 55.3 & 69.0 & 132.4 & -91.7 \\
\hline
\end{tabular}


36 Federal Reserve Bulletin Statistical Supplement $\square$ December 2008

1.57 FUNDS RAISED IN U.S. CREDIT MARKETS ${ }^{\perp}$ - Continued

Billions of dollars; quarterly data at seasonally adjusted annual rates

\begin{tabular}{|c|c|c|c|c|c|c|c|c|c|c|c|c|}
\hline \multirow{2}{*}{ Transaction category or sector } & \multirow{2}{*}{2002} & \multirow{2}{*}{2003} & \multirow{2}{*}{2004} & \multirow{2}{*}{2005} & \multirow{2}{*}{2006} & \multicolumn{2}{|c|}{2006} & \multicolumn{4}{|c|}{2007} & \multirow{2}{*}{$\frac{2008}{\mathrm{Q} 1}$} \\
\hline & & & & & & Q3 & Q4 & Q1 & $\mathrm{Q}^{2}$ & Q3 & Q4 & \\
\hline & \multicolumn{12}{|c|}{ All sectors } \\
\hline 47 Total net borrowing, all sectors ... & $2,362.2$ & $2,770.9$ & $3,057.2$ & $3,413.9$ & $3,874.5$ & $3,483.9$ & $3,810.8$ & $3,707.8$ & $3,726.4$ & $5,093.3$ & $3,693.5$ & $3,115.1$ \\
\hline 48 Open market paper & -99.1 & -82.0 & 106.2 & 245.1 & 317.1 & 413.6 & 294.1 & 232.6 & 426.0 & -913.9 & -422.4 & 77.7 \\
\hline 49 Treasury securities & 257.1 & 398.4 & 362.5 & 307.3 & 183.7 & 172.4 & 135.8 & 327.5 & -70.7 & 435.9 & 257.1 & 487.5 \\
\hline 50 Agency- and GSE-backed securities & 547.2 & 579.1 & 122.3 & 82.8 & 330.6 & 199.9 & 320.1 & 547.9 & 696.2 & $1,178.0$ & $1,211.9$ & 655.2 \\
\hline 51 Municipal securities ............ & 159.4 & 137.6 & 130.5 & 195.0 & 177.3 & 169.2 & 252.8 & 249.1 & 246.7 & 165.5 & 198.7 & 152.8 \\
\hline 52 Corporate and foreign bonds & 545.7 & 660.5 & 801.8 & 799.0 & $1,159.3$ & 977.2 & $1,515.4$ & 933.4 & 825.6 & $1,396.3$ & 702.2 & 299.8 \\
\hline 53 Bank loans n.e.c. ......... & -80.2 & -58.1 & 72.7 & 169.1 & 123.1 & 108.1 & 38.0 & 120.2 & 181.9 & 548.0 & 470.7 & 458.3 \\
\hline 54 Other loans and advances & 20.2 & 34.6 & 90.9 & 87.4 & 68.6 & -13.9 & 60.0 & 47.8 & 77.0 & $1,042.3$ & 189.4 & 256.9 \\
\hline 55 Mortgages.$\ldots \ldots \ldots \ldots$ & 904.1 & 996.4 & $1,255.2$ & $1,433.8$ & $1,410.3$ & $1,337.8$ & $1,085.7$ & $1,134.2$ & $1,206.0$ & $1,039.0$ & 987.5 & 580.6 \\
\hline \multirow[t]{2}{*}{56 Consumer credit } & 107.9 & 104.4 & 115.0 & 94.5 & 104.4 & 119.7 & 108.9 & 115.1 & 137.7 & 202.1 & 98.5 & 146.1 \\
\hline & \multicolumn{12}{|c|}{ Funds raised through mutual funds and corporate equities } \\
\hline 57 Total net issues & 227.4 & 427.5 & 366.0 & 110.9 & -80.4 & -274.8 & 16.6 & 193.6 & -80.6 & -207.1 & -657.4 & 131.2 \\
\hline 58 Corporate equities & 46.4 & 138.9 & 67.7 & -149.3 & -417.2 & -512.6 & -349.1 & -315.0 & -604.5 & -453.5 & -840.3 & -75.3 \\
\hline 59 Nonfinancial corporations & -41.6 & -42.0 & -126.6 & -363.4 & -614.1 & -534.0 & -751.2 & -572.8 & -814.0 & -831.2 & $-1,124.8$ & -562.2 \\
\hline 60 Foreign shares purchased by U.S. residents & 17.0 & 118.0 & 84.8 & 142.6 & 138.5 & 41.8 & 251.0 & 174.0 & 161.5 & 227.6 & -39.2 & 135.2 \\
\hline 61 Financial corporations .... & 71.0 & 62.9 & 109.5 & 71.5 & 58.4 & -20.4 & 151.2 & 83.8 & 48.0 & 150.1 & 323.6 & 351.7 \\
\hline 62 Mutual fund shares ...... & 181.1 & 288.6 & 298.2 & 260.2 & 336.8 & 237.8 & 365.6 & 508.6 & 523.9 & 246.4 & 183.0 & 206.5 \\
\hline
\end{tabular}

1. Data in this table also appear in the Board's Z.1 quarterly statistical release, tables F.2 through F.4, available at www.federalreserve gov/releases. 
1.58 SUMMARY OF FINANCIAL TRANSACTIONS ${ }^{1}$

Billions of dollars except as noted; quarterly data at seasonally adjusted annual rates

\begin{tabular}{|c|c|c|c|c|c|c|c|c|c|c|c|c|c|}
\hline \multirow{2}{*}{\multicolumn{2}{|c|}{ Transaction category or sector }} & \multirow{2}{*}{2002} & \multirow{2}{*}{2003} & \multirow{2}{*}{2004} & \multirow{2}{*}{2005} & \multirow{2}{*}{2006} & \multicolumn{2}{|c|}{2006} & & 20 & & & 2008 \\
\hline & & & & & & & Q3 & Q4 & Q1 & Q2 & Q3 & Q4 & Q1 \\
\hline & Net LeNding IN CREDIT Markets ${ }^{2}$ & & & & & & & & & & & & \\
\hline 1 & Total net lending in credit markets & $2,362.2$ & $2,770.9$ & $3,057.2$ & $3,413.9$ & $3,874.5$ & $3,483.9$ & $3,810.8$ & $3,707.8$ & $3,726.4$ & $5,093.3$ & $3,693.5$ & $3,115.1$ \\
\hline 2 & Domestic nonfinancial sectors & 152.0 & 157.8 & 291.6 & 284.5 & 293.8 & 286.6 & 332.8 & 90.5 & 189.6 & 645.1 & 515.4 & $-1,014.9$ \\
\hline & Household............. & 35.9 & 103.4 & 173.9 & 109.3 & 203.7 & 277.2 & 181.0 & -185.6 & 78.6 & 867.6 & 631.3 & -921.9 \\
\hline & Nonfinancial corporate business & 25.8 & -3.2 & 31.1 & 42.3 & -10.9 & -70.5 & 7.5 & 98.7 & -62.4 & -195.6 & -86.2 & -92.7 \\
\hline & Nonfarm noncorporate business .... & -8 & 1.5 & 11.5 & 11.4 & 12.3 & 12.6 & 12.5 & 12.1 & 14.0 & 17.3 & 16.4 & 11.8 \\
\hline 6 & State and local governments ... & 86.2 & 58.3 & 72.4 & 124.1 & 84.6 & 81.3 & 122.9 & 145.0 & 144.9 & -40.1 & -57.0 & -31.9 \\
\hline & Federal government ....... & 4.9 & -2.1 & 2.7 & -2.7 & 4.0 & -14.0 & 8.9 & 20.3 & 14.6 & -4.2 & 11.0 & 19.8 \\
\hline 8 & Rest of the world ............ & 467.2 & 582.8 & 854.4 & 749.0 & 855.0 & 724.1 & 952.2 & $1,017.9$ & 866.5 & 587.2 & 835.2 & 996.0 \\
\hline 91 & Financial sectors & $1,743.1$ & $2,030.2$ & $1,911.1$ & $2,380.4$ & $2,725.7$ & $2,473.2$ & $2,525.8$ & $2,599.4$ & $2,670.3$ & $3,861.0$ & $2,342.8$ & $3,133.9$ \\
\hline 10 & Monetary authority & 77.7 & 37.2 & 51.2 & 26.4 & 34.7 & 21.4 & 21.4 & 13.0 & 44.7 & -33.7 & -177.2 & -430.9 \\
\hline 11 & Commercial banking & 404.4 & 332.9 & 608.0 & 658.4 & 761.7 & 154.5 & $1,274.7$ & 204.1 & 678.4 & 963.4 & $1,157.4$ & 592.5 \\
\hline 12 & U.S.-chartered commercial banks & 393.8 & 352.2 & 571.1 & 507.9 & 656.3 & 57.3 & $1,165.9$ & 39.3 & 489.7 & 704.5 & 882.2 & 427.3 \\
\hline 13 & Foreign banking offices in United States ....... & 6.2 & -38.5 & 23.0 & 144.5 & 103.7 & 94.0 & 100.3 & 188.2 & 194.9 & 238.1 & 185.7 & 160.9 \\
\hline 14 & Bank holding companies $\ldots \ldots \ldots \ldots \ldots \ldots \ldots \ldots$ & 3.1 & 8.6 & .0 & -4.2 & 3.3 & 6.6 & 8.0 & -16.8 & -5.3 & 21.4 & 93.0 & 4.0 \\
\hline 15 & Banks in U.S.-affiliated areas & 1.3 & 10.6 & 13.9 & 10.2 & -1.7 & -3.3 & .5 & -6.5 & -.9 & -.7 & -3.5 & .3 \\
\hline 16 & Savings institutions.$\ldots \ldots \ldots$. & 33.4 & 127.3 & 103.5 & 199.3 & -98.1 & 258.1 & -859.7 & 189.1 & 67.4 & 136.8 & -130.6 & 8.3 \\
\hline 17 & Credit unions ...... & 44.2 & 51.2 & 39.8 & 36.2 & 30.1 & 7.9 & 27.7 & 39.8 & 24.6 & 40.9 & 35.7 & 45.0 \\
\hline 18 & Property-casualty insurance companies & 39.9 & 67.0 & 73.6 & 66.9 & 47.7 & 31.8 & 50.6 & 32.8 & 34.7 & 34.0 & 4.4 & 48.3 \\
\hline 19 & Life insurance companies .......... & 233.0 & 180.6 & 173.0 & 110.3 & 75.6 & 48.6 & 7.7 & 94.3 & 99.5 & 99.3 & 45.5 & 90.8 \\
\hline 20 & Private pension funds... & -8.6 & 69.2 & -.3 & 44.5 & 14.0 & 38.9 & 41.6 & 30.7 & 39.6 & 50.1 & 14.0 & 31.6 \\
\hline 21 & State and local government retirement funds .... & -50.7 & 18.8 & 17.8 & 18.1 & 76.3 & 14.4 & 43.7 & -8.4 & 18.6 & 61.3 & 49.1 & 42.9 \\
\hline 22 & Federal government retirement funds ......... & 12.7 & 6.0 & 4.7 & 7.7 & 8.4 & 7.6 & 2.5 & 14.9 & 3.4 & 17.5 & 11.1 & 40.1 \\
\hline 23 & Money market mutual funds . .............. & -17.7 & -95.9 & -124.9 & -5.5 & 220.0 & 362.1 & 216.5 & 431.1 & 290.4 & 444.2 & 396.9 & $1,293.4$ \\
\hline 24 & Mutual funds $\ldots \ldots \ldots \ldots$. & 138.7 & 138.0 & 116.6 & 124.1 & 184.9 & 130.8 & 232.6 & 285.2 & 365.6 & 184.4 & 249.3 & 252.8 \\
\hline 25 & Closed-end funds & 8.6 & 35.5 & 11.0 & 1.5 & 6.7 & -4.9 & 5.5 & -.9 & 13.9 & -18.0 & 5.9 & -6.0 \\
\hline 26 & Exchange-traded funds & 3.7 & .7 & 3.8 & 6.8 & 5.7 & 2.8 & 7.9 & 6.8 & 15.6 & 9.6 & 18.9 & 17.5 \\
\hline 27 & Government-sponsored enterprises & 224.1 & 241.0 & 48.9 & -69.1 & 46.6 & -30.4 & 51.7 & -86.9 & 81.0 & 673.3 & 288.6 & 298.0 \\
\hline 28 & Agency- and GSE-backed mortgage pools ........ & 326.8 & 330.6 & 47.9 & 167.3 & 295.4 & 284.4 & 278.9 & 482.5 & 534.9 & 622.2 & 866.3 & 534.1 \\
\hline 29 & Asset-backed securities issuers (AB Ss) . . . . . . . . & 219.0 & 233.2 & 416.2 & 673.6 & 725.8 & 721.3 & 728.6 & 585.2 & 484.0 & 167.1 & -242.1 & -292.3 \\
\hline 30 & Finance companies ........ & 103.7 & 122.9 & 214.9 & 117.2 & 89.7 & 158.1 & -5.8 & 56.5 & -34.7 & 110.5 & -92.9 & 88.6 \\
\hline 31 & Real estate investment trusts (REITs) & 23.8 & 25.7 & 87.9 & 66.9 & 57.5 & 44.5 & 87.1 & -36.2 & -48.8 & -135.8 & 8.6 & -39.4 \\
\hline 32 & Brokers and dealers ............... & 28.4 & 79.6 & -29.2 & 82.3 & 106.2 & 162.5 & 218.5 & 279.7 & -199.0 & 436.3 & 362.0 & 174.2 \\
\hline 33 & Funding corporations & -102.1 & 28.6 & 47.0 & 47.5 & 36.9 & 58.6 & 94.1 & -13.9 & 156.4 & -2.5 & -528.3 & 344.7 \\
\hline & $\begin{array}{l}\text { RELATION OF LIABILITIES } \\
\text { TO FINANCIAL ASSETS }\end{array}$ & & & & & & & & & & & & \\
\hline 34 & Net flows through credit markets & $2,362.2$ & $2,770.9$ & $3,057.2$ & $3,413.9$ & $3,874.5$ & $3,483.9$ & $3,810.8$ & $3,707.8$ & $3,726.4$ & $5,093.3$ & $3,693.5$ & $3,115.1$ \\
\hline & Other finan & & & & & & & & & & & & \\
\hline 35 & Official foreign exchange & 3.2 & -.9 & -3.2 & -9.6 & -2.6 & -4.2 & -5.9 & .1 & -.3 & .1 & -.1 & .2 \\
\hline 36 & Special drawing rights certificates & .0 & .0 & .0 & .0 & .0 & .0 & .0 & .0 & .0 & .0 & .0 & .0 \\
\hline 37 & Treasury currency..$\ldots \ldots \ldots \ldots$ & 1.0 & .6 & .7 & 8 & .6 & 1.0 & .0 & .4 & 1.3 & 1.4 & -.4 & -.9 \\
\hline 38 & Foreign deposits . & 21.0 & 36.0 & 89.9 & 67.8 & 98.8 & -38.7 & -64.4 & 284.6 & 395.3 & 185.7 & 41.3 & 50.0 \\
\hline 39 & Net interbank transactions & 17.4 & -14.5 & 19.4 & -12.4 & -11.2 & 43.9 & 116.5 & -487.0 & 22.2 & 205.5 & 100.8 & -231.3 \\
\hline 40 & Checkable deposits and currency & -8.3 & 85.0 & 84.8 & 3.5 & -18.7 & -73.0 & -75.2 & 91.9 & -99.2 & 124.0 & 9 & 74.8 \\
\hline 41 & Small time and savings deposits. & 325.4 & 307.4 & 281.6 & 314.4 & 347.0 & 336.8 & 578.7 & 386.4 & 205.8 & 329.4 & 223.8 & 461.9 \\
\hline 42 & Large time deposits ......... & 50.0 & 55.8 & 252.9 & 284.4 & 261.2 & 344.7 & -3.6 & 276.7 & 107.4 & 529.0 & 365.3 & 320.6 \\
\hline 43 & Money market fund shares & -16.7 & -207.5 & -136.5 & 127.0 & 305.3 & 418.0 & 378.8 & 441.4 & 442.5 & $1,260.4$ & 819.9 & $1,549.3$ \\
\hline 44 & Security repurchase agreements & 106.6 & 218.7 & 88.1 & 350.8 & 496.0 & 602.2 & 619.1 & 707.9 & 116.6 & 222.3 & -670.4 & 96.3 \\
\hline 45 & Corporate equities ............ & 46.4 & 138.9 & 67.7 & -149.3 & -417.2 & -512.6 & $-\mathbf{3 4 9 . 1}$ & -315.0 & -604.5 & -453.5 & -840.3 & -75.3 \\
\hline 46 & Mutual fund shares $\ldots \ldots \ldots \ldots \ldots \ldots$ & 181.1 & 288.6 & 298.2 & 260.2 & 336.8 & 237.8 & 365.6 & 508.6 & 523.9 & 246.4 & 183.0 & 206.5 \\
\hline 47 & Trade payables & 86.7 & 22.4 & 194.4 & 336.6 & 217.4 & 123.3 & 211.0 & 295.5 & 334.0 & 283.6 & 221.5 & 275.4 \\
\hline 48 & Security credit $\ldots . .$. & -87.0 & 120.0 & 179.4 & .2 & 211.5 & 173.0 & 274.2 & 105.5 & 365.7 & -19.1 & 653.9 & 313.3 \\
\hline 49 & Life insurance reserves & 60.1 & 66.8 & 33.1 & 16.1 & 65.6 & 76.3 & 75.4 & 28.4 & 36.4 & 28.9 & 43.1 & 23.4 \\
\hline 50 & Pension fund reserves $\ldots \ldots \ldots \ldots \ldots \ldots \ldots \ldots \ldots \ldots$ & 262.9 & 258.5 & 288.4 & 238.3 & 198.2 & 161.8 & 216.9 & 136.4 & 149.2 & 164.4 & 227.7 & 149.5 \\
\hline 51 & Taxes payable. & 22.2 & -1.1 & 28.5 & 28.1 & 19.9 & 21.3 & 28.4 & 33.1 & 11.9 & 26.1 & 25.4 & 25.4 \\
\hline 52 & Noncorporate proprietors equity & -84.1 & 45.0 & -18.0 & -137.8 & -54.0 & -26.6 & -62.6 & 15.0 & -48.4 & -122.0 & -107.5 & -18.3 \\
\hline 53 & Miscellaneous ............... & 505.3 & 456.9 & $1,616.0$ & $1,389.1$ & $1,724.0$ & $2,007.7$ & $1,538.5$ & $1,208.9$ & $3,550.3$ & $2,225.8$ & $1,049.5$ & $1,424.4$ \\
\hline 54 & Total financial sources & $3,855.6$ & $4,647.3$ & $6,422.6$ & $6,522.1$ & $7,653.1$ & $7,376.6$ & $7,653.2$ & $7,426.7$ & $9,236.7$ & $10,331.7$ & $6,030.6$ & $7,760.4$ \\
\hline & Liabilities not identi & & & & & & & & & & & & \\
\hline 55 & Treasury currency & -.6 & -.3 & -.3 & .7 & -1.1 & 6 & -.5 & -.3 & .7 & .9 & -.6 & -.9 \\
\hline 56 & Foreign deposits & 21.5 & 52.8 & 61.9 & 40.6 & 114.3 & 37.0 & -138.0 & 297.0 & 377.1 & 49.0 & -59.5 & -11.1 \\
\hline 57 & Net interbank liabilities & 7.2 & -4.3 & 14.9 & -3.7 & -1.9 & 48.1 & -71.8 & 50.5 & -54.5 & -12.6 & 23.7 & -15.8 \\
\hline 58 & Security repurchase agreements & 36.0 & -33.9 & -139.9 & 134.2 & 297.9 & 144.6 & 601.8 & -73.6 & -33.9 & 103.8 & -814.6 & -18.9 \\
\hline 59 & Taxes payable...$\ldots \ldots \ldots \ldots$. & 19.7 & -42.6 & -20.2 & -18.1 & 1.9 & 24.1 & 23.7 & -29.2 & -23.0 & -24.3 & -5.5 & -69.3 \\
\hline 60 & Miscellaneous & -23.0 & -26.2 & 198.8 & 177.8 & -201.2 & -123.7 & -44.5 & -958.6 & 647.3 & -172.5 & 934.5 & 79.2 \\
\hline & Floats not & & & & & & & & & & & & \\
\hline 61 & Federal government checkable deposits & -1.6 & -8.9 & 27.9 & -6.6 & -3.0 & 16.4 & -19.1 & -5.9 & -.5 & 13.5 & -2.4 & -5.7 \\
\hline 62 & Other checkable deposits ............ & -.7 & & -8 & -.9 & -.5 & -9 & -8 & -8 & -1.3 & -.8 & -1.2 & -1.0 \\
\hline 63 & Trade credit........ & 164.9 & 20.6 & 9.4 & -31.7 & 96.6 & 76.9 & 140.0 & 276.7 & -54.1 & -8.5 & 8.4 & 25.9 \\
\hline 64 & Total identified to sectors as assets & $3,632.1$ & $4,690.1$ & $6,270.9$ & $6,229.9$ & $7,350.0$ & $7,153.6$ & $7,162.5$ & $7,870.9$ & $8,378.8$ & $10,383.2$ & $5,947.9$ & $7,777.9$ \\
\hline
\end{tabular}

1. Data in this table also appear in the Board's Z.1 quarterly statistical release, tables F.1

2. Excludes corporate equities and mutual fund shares.

and F.5, available at www.federalreserve.gov/releases. 
1.59 SUMMARY OF CREDIT MARKET DEBT OUTSTANDING ${ }^{1}$

Billions of dollars, end of period

\begin{tabular}{|c|c|c|c|c|c|c|c|c|c|c|c|c|}
\hline \multirow{2}{*}{\multicolumn{2}{|c|}{ Transaction category or sector }} & \multirow{2}{*}{2003} & \multirow{2}{*}{2004} & \multirow{2}{*}{2005} & \multirow{2}{*}{2006} & \multicolumn{2}{|c|}{2006} & \multicolumn{4}{|c|}{2007} & \multirow{2}{*}{$\frac{2008}{\mathrm{Q} 1}$} \\
\hline & & & & & & Q3 & Q4 & Q1 & Q2 & $\mathrm{Q} 3$ & Q4 & \\
\hline & & \multicolumn{11}{|c|}{ Nonfinancial sectors } \\
\hline & $\begin{array}{l}\text { Total credit market debt owed by } \\
\text { domestic nonfinancial sectors }\end{array}$ & $22,327.3$ & $24,299.8$ & $26,547.1$ & $28,876.2$ & $28,268.7$ & $28,876.2$ & $29,463.5$ & $29,956.2$ & $30,622.2$ & $31,249.3$ & $\mathbf{3 1 , 7 6 3 . 0}$ \\
\hline & By instrument & & & & & & & & & & & \\
\hline 2 & Commercial paper & 82.5 & 97.8 & 90.1 & 112.5 & 110.6 & 112.5 & 126.2 & 154.3 & 131.4 & 123.8 & 140.0 \\
\hline 3 & Treasury securities & $4,008.2$ & $4,370.7$ & $4,678.0$ & $4,861.7$ & $4,803.2$ & $4,861.7$ & $5,014.3$ & $4,904.0$ & $5,010.0$ & $5,099.2$ & $5,299.1$ \\
\hline 4 & Agency- and GSE-backed securities & 24.9 & 24.3 & 23.8 & 23.5 & 23.4 & 23.5 & 23.2 & 23.2 & 23.0 & 23.1 & 23.5 \\
\hline 5 & Municipal securities and loans ... & $1,900.5$ & $2,031.0$ & $2,225.9$ & $2,403.2$ & $2,332.7$ & $2,403.2$ & $2,465.6$ & $2,533.8$ & $2,560.8$ & $2,618.2$ & $2,656.9$ \\
\hline 6 & Corporate bonds ............. & $2,870.1$ & $2,944.5$ & $2,998.1$ & $3,211.5$ & $3,132.5$ & $3,211.5$ & $3,282.1$ & $3,376.4$ & $3,432.7$ & $3,525.6$ & $3,594.3$ \\
\hline 7 & Bank loans n.e.c. & $1,088.4$ & $1,099.2$ & $1,236.8$ & $1,410.2$ & $1,361.6$ & $1,410.2$ & $1,433.9$ & $1,466.2$ & $1,572.7$ & $1,665.6$ & $1,727.3$ \\
\hline 8 & Other loans and advances & 955.4 & 975.8 & $1,023.5$ & $1,075.1$ & $1,046.2$ & $1,075.1$ & $1,087.3$ & $1,118.7$ & $1,176.0$ & $1,191.0$ & $1,208.2$ \\
\hline 9 & Mortgages $\ldots \ldots \ldots \ldots$ & $9,293.1$ & $10,537.2$ & $11,957.0$ & $13,360.2$ & $13,091.5$ & $13,360.2$ & $13,631.5$ & $13,946.3$ & $14,209.5$ & $14,446.2$ & $14,570.9$ \\
\hline 10 & Home. & $7,230.5$ & $8,273.4$ & $9,379.4$ & $10,451.7$ & $10,279.0$ & $10,451.7$ & $10,652.4$ & $10,862.2$ & $11,015.8$ & $11,158.3$ & $11,226.5$ \\
\hline 11 & Multifamily residential & 543.6 & 591.9 & 663.6 & 716.3 & 699.3 & 716.3 & 732.1 & 755.8 & 782.0 & 814.4 & 831.7 \\
\hline 12 & Commercial ........ & $1,424.8$ & $1,575.0$ & $1,812.5$ & $2,083.2$ & $2,006.2$ & $2,083.2$ & $2,135.9$ & $2,215.0$ & $2,296.3$ & $2,356.0$ & $2,394.4$ \\
\hline 13 & Farm $\ldots \ldots \ldots \ldots$ & 94.1 & 96.9 & 101.5 & 109.0 & 107.1 & 109.0 & 111.1 & 113.2 & 115.4 & 117.5 & 118.3 \\
\hline 14 & Consumer credit $\ldots \ldots \ldots \ldots \ldots$ & $2,104.4$ & $2,219.4$ & $2,313.9$ & $2,418.3$ & $2,367.0$ & $2,418.3$ & $2,399.5$ & $2,433.3$ & $2,506.1$ & $2,556.6$ & $2,542.9$ \\
\hline & By borrowing sector & & & & & & & & & & & \\
\hline 15 & Households. & $9,499.5$ & $10,578.2$ & $11,759.2$ & $12,956.1$ & $12,715.4$ & $12,956.1$ & $13,129.0$ & $13,378.2$ & $13,628.0$ & $13,839.7$ & $13,906.7$ \\
\hline 16 & Nonfinancial business & $7,227.2$ & $7,643.7$ & $8,231.6$ & $9,029.3$ & $8,781.3$ & $9,029.3$ & $9,234.7$ & $9,529.6$ & $9,817.8$ & $10,096.6$ & $10,307.2$ \\
\hline 17 & Corporate ........ & $4,860.3$ & $5,026.0$ & $5,269.6$ & $5,699.8$ & $5,548.5$ & $5,699.8$ & $5,829.2$ & $6,023.3$ & $6,175.0$ & $6,331.0$ & $6,458.6$ \\
\hline 18 & Nonfarm noncorporate & $2,198.8$ & $2,443.5$ & $2,775.0$ & $3,124.2$ & $3,033.1$ & $3,124.2$ & $3,198.1$ & $3,293.4$ & $3,425.1$ & $3,541.9$ & $3,621.8$ \\
\hline 19 & Farm $\ldots \ldots \ldots \ldots \ldots$ & 168.1 & 174.2 & 186.9 & 205.3 & 199.7 & 205.3 & 207.4 & 212.9 & 217.7 & 223.7 & 226.9 \\
\hline 20 & State and local government & $1,567.6$ & $1,682.8$ & $1,854.4$ & $2,005.6$ & $1,945.4$ & $2,005.6$ & $2,062.4$ & $2,121.2$ & $2,143.5$ & $2,190.7$ & $2,226.6$ \\
\hline 21 & Federal government ...... & $4,033.1$ & $4,395.0$ & $4,701.9$ & $4,885.3$ & $4,826.6$ & $4,885.3$ & $5,037.4$ & $4,927.2$ & $5,032.9$ & $5,122.3$ & $5,322.6$ \\
\hline 22 & $\begin{array}{c}\text { Foreign credit market debt held in } \\
\text { United States } \ldots \ldots \ldots \ldots \ldots \ldots\end{array}$ & $1,258.1$ & $1,445.7$ & 1528.9 & $1,785.1$ & 1.716 .9 & $1,785.1$ & $1,799.0$ & 1.848 .5 & 1.849 .6 & 1.862 .6 & $1,926.3$ \\
\hline 23 & Commercial paper & 275.5 & 344.2 & 382.4 & 479.5 & 474.3 & 479.5 & 474.0 & 472.2 & 424.2 & 412.2 & 460.2 \\
\hline 24 & Bonds ......... & 874.4 & 993.0 & $1,028.2$ & $1,180.8$ & $1,124.6$ & $1,180.8$ & $1,224.5$ & $1,266.3$ & $1,309.6$ & $1,323.6$ & $1,333.6$ \\
\hline 25 & Bank loans n.e.c. & 66.1 & 69.9 & 84.4 & 98.3 & 90.4 & 98.3 & 74.7 & 84.9 & 91.5 & 102.8 & 108.8 \\
\hline 26 & Other loans and advances & 42.2 & 38.6 & 34.0 & 26.6 & 27.7 & 26.6 & 25.8 & 25.1 & 24.4 & 24.0 & 23.7 \\
\hline 27 & $\begin{array}{l}\text { Total credit market debt owed by nonfinancial } \\
\text { sectors, domestic and foreign } \ldots \ldots \ldots \ldots\end{array}$ & $23,585.4$ & $25,745.5$ & $28,076.0$ & $30,661.3$ & $29,985.6$ & $30,661.3$ & $31,262.5$ & $31,804.7$ & $32,471.8$ & $33,111.9$ & $33,689.3$ \\
\hline & & & & & & & ancial sec & & & & & \\
\hline 28 & $\begin{array}{l}\text { Total credit market debt owed by } \\
\quad \text { financial sectors } \ldots \ldots \ldots . . .\end{array}$ & $10,875.5$ & $11,859.0$ & $12,868.5$ & $14,153.7$ & $13,816.8$ & $14,153.7$ & $14,449.0$ & $14,800.4$ & $15,384.9$ & $15,745.3$ & $15,925.1$ \\
\hline & By instrument & & & & & & & & & & & \\
\hline 29 & Open market paper & 935.0 & 957.1 & $1,171.7$ & $1,366.0$ & $1,280.5$ & $1,366.0$ & $1,403.5$ & $1,483.3$ & $1,302.0$ & $1,252.6$ & $1,184.4$ \\
\hline 30 & Government-sponsored enterprise securities & $2,601.3$ & $2,676.3$ & $2,592.2$ & $2,627.8$ & $2,617.6$ & $2,627.8$ & $2,644.5$ & $2,684.8$ & $2,824.0$ & $2,910.2$ & $2,940.2$ \\
\hline 31 & Agency- and GSE-backed mortgage pool & & & & & & & & & & & \\
\hline & securities & $3,326.7$ & $3,374.6$ & $3,541.9$ & $3,837.3$ & $3,763.1$ & $3,837.3$ & $3,955.7$ & $4,075.8$ & $4,243.2$ & $4,463.7$ & $4,594.6$ \\
\hline 32 & Corporate bonds & $3,242.1$ & $3,922.5$ & $4,559.0$ & $5,354.8$ & $5,129.9$ & $5,354.8$ & $5,489.9$ & $5,567.8$ & $5,815.5$ & $5,862.1$ & $5,875.3$ \\
\hline 33 & Bank loans n.e.c. & 164.0 & 222.1 & 239.1 & 175.0 & 229.0 & 175.0 & 183.3 & 196.8 & 225.2 & 232.2 & 271.8 \\
\hline 34 & Other loans and advances & 501.7 & 575.8 & 620.2 & 641.4 & 643.7 & 641.4 & 624.4 & 642.0 & 821.8 & 867.1 & 896.4 \\
\hline 35 & Mortgages & 104.7 & 130.6 & 144.5 & 151.5 & 153.0 & 151.5 & 147.7 & 150.0 & 153.2 & 157.2 & 162.4 \\
\hline & By borrowing sector & & & & & & & & & & & \\
\hline 36 & Commercial banks & 338.6 & 357.4 & 394.3 & 498.3 & 424.1 & 498.3 & 495.3 & 511.0 & 597.5 & 630.1 & 647.5 \\
\hline 37 & Bank holding companies & 321.8 & 381.3 & 429.5 & 499.7 & 476.2 & 499.7 & 520.3 & 551.5 & 586.8 & 631.1 & 665.4 \\
\hline 38 & Savings institutions ..... & 296.8 & 385.8 & 409.6 & 297.8 & 412.4 & 297.8 & 288.3 & 289.5 & 375.9 & 395.1 & 407.2 \\
\hline 39 & Credit unions . .......... & 9.1 & 11.4 & 14.7 & 18.9 & 16.8 & 18.9 & 16.2 & 18.9 & 28.4 & 32.3 & 28.5 \\
\hline 40 & Life insurance companies & 8.0 & 11.1 & 11.5 & 14.2 & 13.1 & 14.2 & 15.4 & 18.6 & 25.3 & 28.7 & 31.1 \\
\hline 41 & Government-sponsored enterprises & $2,601.3$ & $2,676.3$ & $2,592.2$ & $2,627.8$ & $2,617.6$ & $2,627.8$ & $2,644.5$ & $2,684.8$ & $2,824.0$ & $2,910.2$ & $2,940.2$ \\
\hline 42 & Agency- and GSE-backed mortgage pools & $3,326.7$ & $3,374.6$ & $3,541.9$ & $3,837.3$ & $3,763.1$ & $3,837.3$ & $3,955.7$ & $4,075.8$ & $4,243.2$ & $4,463.7$ & $4,594.6$ \\
\hline 43 & Issuers of asset-backed securities (ABSs). & $2,181.7$ & $2,609.0$ & $3,278.3$ & $4,050.3$ & $3,816.8$ & $4,050.3$ & $4,155.3$ & $4,280.5$ & $4,294.9$ & $4,228.8$ & $4,150.9$ \\
\hline 44 & Brokers and dealers ........ & 47.0 & 62.2 & 62.4 & 68.8 & 74.0 & 68.8 & 83.7 & 93.6 & 86.3 & 64.8 & 80.4 \\
\hline 45 & Finance companies. & 995.3 & $1,129.6$ & $1,108.6$ & $1,144.2$ & $1,119.5$ & $1,144.2$ & $1,133.6$ & $1,135.2$ & $1,173.3$ & $1,169.1$ & $1,173.3$ \\
\hline 46 & Real estate investment trusts (REITs) & 230.0 & 343.2 & 402.9 & 444.0 & 440.5 & 444.0 & 444.6 & 439.3 & 435.6 & 438.2 & 428.1 \\
\hline 47 & Funding corporations...$\ldots \ldots \ldots \ldots$ & 519.3 & 517.1 & 622.7 & 652.5 & 642.6 & 652.5 & 696.1 & 701.8 & 713.8 & 753.2 & 738.1 \\
\hline & & & & & & & All sectors & & & & & \\
\hline 48 & Total credit market debt, domestic and foreign . & $34,460.9$ & $37,604.5$ & $40,944.6$ & $\mathbf{4 4 , 8 1 4 . 9}$ & $43,802.4$ & $44,814.9$ & $45,711.5$ & $46,605.1$ & $47,856.7$ & $48,857.2$ & $49,614.4$ \\
\hline 49 & Open market paper & $1,292.9$ & $1,399.1$ & 1.644 .2 & 1.958 .0 & 1.865 .3 & $1,958.0$ & $2,003.7$ & $2,109.8$ & $1,857.6$ & $1,788.6$ & 1.784 .6 \\
\hline 50 & Treasury securities & $4,008.2$ & $4,370.7$ & $4,678.0$ & $4,861.7$ & $4,803.2$ & $4,861.7$ & $5,014.3$ & $4,904.0$ & $5,010.0$ & $5,099.2$ & $5,299.1$ \\
\hline 51 & Agency- and GSE-backed securities & $5,952.9$ & $6,075.2$ & $6,158.0$ & $6,488.6$ & $6,404.1$ & $6,488.6$ & $6,623.4$ & $6,783.8$ & $7,090.2$ & $7,397.1$ & $7,558.2$ \\
\hline 52 & Municipal securities & $1,900.5$ & $2,031.0$ & $2,225.9$ & $2,403.2$ & $2,332.7$ & $2,403.2$ & $2,465.6$ & $2,533.8$ & $2,560.8$ & $2,618.2$ & $2,656.9$ \\
\hline 53 & Corporate and foreign bonds & $6,986.6$ & $7,860.0$ & $8,585.2$ & $9,747.0$ & $9,387.0$ & $9,747.0$ & $9,996.4$ & $10,210.5$ & $10,557.9$ & $10,711.4$ & $10,803.2$ \\
\hline 54 & Bank loans n.e.c. .. & $1,318.4$ & $1,391.2$ & $1,560.3$ & $1,683.4$ & $1,681.0$ & $1,683.4$ & $1,692.0$ & $1,747.9$ & $1,889.4$ & $2,000.6$ & $2,107.9$ \\
\hline 55 & Other loans and advances & $1,499.3$ & $1,590.2$ & $1,677.6$ & $1,743.0$ & $1,717.6$ & $1,743.0$ & $1,737.5$ & $1,785.8$ & $2,022.1$ & $2,082.1$ & $2,128.3$ \\
\hline 56 & Mortgages .. & $9,397.7$ & $10,667.7$ & $12,101.5$ & $13,511.7$ & $13,244.5$ & $13,511.7$ & $13,779.2$ & $14,096.2$ & $14,362.7$ & $14,603.4$ & $14,733.3$ \\
\hline 57 & Consumer credit . & $2,104.4$ & $2,219.4$ & 2.313 .9 & 2.418 .3 & $2,367.0$ & $2,418.3$ & $2,399.5$ & $2,433.3$ & $2,506.1$ & $2,556.6$ & $2,542.9$ \\
\hline
\end{tabular}

1. Data in this table appear in the Board's Z.1 quarterly statistical release, tables L.2

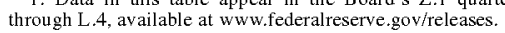


1.60 SUMMARY OF FINANCIAL ASSETS AND LIABILITIES ${ }^{1}$

Billions of dollars except as noted, end of period

\begin{tabular}{|c|c|c|c|c|c|c|c|c|c|c|c|c|}
\hline \multirow{2}{*}{\multicolumn{2}{|c|}{ Transaction category or sector }} & \multirow{2}{*}{2003} & \multirow{2}{*}{2004} & \multirow{2}{*}{2005} & \multirow{2}{*}{2006} & \multicolumn{2}{|c|}{2006} & & 20 & 07 & & 2008 \\
\hline & & & & & & Q3 & Q4 & Q1 & Q2 & Q3 & Q4 & Q1 \\
\hline & CREDIT Market DebT OUtSTANDinG ${ }^{2}$ & & & & & & & & & & & \\
\hline 1 & Total credit market assets & $34,460.9$ & $37,604.5$ & $40,944.6$ & $44,814.9$ & $43,802.4$ & $44,814.9$ & $45,711.5$ & $46,605.1$ & $47,856.7$ & $48,857.2$ & $49,614.4$ \\
\hline & Domestic nonfinancial sectors & $4,686.6$ & $5,085.8$ & $5,498,0$ & $5,832.2$ & $5,705.4$ & $5,832.2$ & $5,891.1$ & $5,909.8$ & $6,063.7$ & $6,192.3$ & $5,981.7$ \\
\hline & Household .. & $2,947.1$ & $3,228.4$ & $3,465.6$ & $3,709.6$ & $3,624.3$ & $3,709.6$ & $3,721.1$ & $3,707.6$ & $3,905.1$ & $4,057.6$ & $3,894.6$ \\
\hline & Nonfinancial corporate business & 266.2 & 297.4 & 339.6 & 328.8 & 320.2 & 328.8 & 332.0 & 317.2 & 280.2 & 267.4 & 219.8 \\
\hline & Nonfarm noncorporate business & 73.9 & 85.4 & 96.8 & 109.1 & 106.0 & 109.1 & 112.1 & 115.6 & 119.9 & 124.0 & 127.0 \\
\hline 6 & State and local governments ... & $1,125.6$ & $1,198.1$ & $1,322.2$ & $1,406.8$ & $1,376.9$ & $1,406.8$ & $1,442.6$ & $1,484.9$ & $1,470.6$ & $1,455.0$ & $1,446.8$ \\
\hline & Federal government ........ & 273.8 & 276.5 & 273.8 & 277.9 & 278.0 & 277.9 & 283.2 & 284.5 & 287.9 & 288.3 & 293.5 \\
\hline & Rest of the world & $3,836.1$ & $4,634.7$ & $5,188.3$ & $6,040.5$ & $5,807.5$ & $6,040.5$ & $6,292.4$ & $6,516.6$ & $6,659.3$ & $6,867.2$ & $7,114.1$ \\
\hline & Financial sectors & $25,938.1$ & $27,884.0$ & $30,258.2$ & $32,942.3$ & $32,289.5$ & $32,942.3$ & $33,528.0$ & $34,178.8$ & $35,133.7$ & $35,797.7$ & $36,518.5$ \\
\hline 10 & Monetary authority & 666.7 & 717.8 & 744.2 & 778.9 & 768.9 & 778.9 & 780.9 & 790.5 & 779.6 & 740.6 & 631.0 \\
\hline 11 & Commercial banking ..... & $5,994.3$ & $6,602.3$ & $7,260.7$ & $8,019.1$ & $7,696.9$ & $8,019.1$ & $8,025.9$ & $8,217.4$ & $8,465.0$ & $8,757.0$ & $8,875.3$ \\
\hline 12 & U.S.-chartered commercial banks & $5,390.6$ & $5,961.8$ & $6,469.7$ & $7,122.7$ & $6,828.0$ & $7,122.7$ & $7,091.0$ & $7,234.7$ & $7,417.6$ & $7,638.7$ & $7,718.6$ \\
\hline 13 & Foreign banking offices in United States ...... & 490.3 & 513.3 & 657.8 & 761.6 & 736.2 & 761.6 & 805.9 & 855.3 & 914.8 & 963.3 & $1,000.6$ \\
\hline 14 & Bank holding companies $\ldots \ldots \ldots \ldots$ & 36.4 & 36.4 & 32.2 & 35.6 & 33.6 & 35.6 & 31.4 & 30.1 & 35.4 & 58.7 & 59.7 \\
\hline 15 & Banks in U.S.-affiliated areas & 76.9 & 90.8 & 101.0 & 99.3 & 99.1 & 99.3 & 97.6 & 97.4 & 97.2 & 96.4 & 96.4 \\
\hline 16 & Savings institutions $\ldots \ldots \ldots$. & $1,293.9$ & $1,417.4$ & $1,616.7$ & $1,518.6$ & $1,744.5$ & $1,518.6$ & $1,577.5$ & $1,595.2$ & $1,628.9$ & $1,584.3$ & $1,598.8$ \\
\hline 17 & Credit unions & 516.6 & 556.4 & 592.6 & 622.7 & 618.9 & 622.7 & 629.2 & 641.0 & 652.6 & 657.9 & 665.5 \\
\hline 18 & Property-casualty insurance companies & 625.2 & 698.8 & 765.8 & 813.5 & 800.8 & 813.5 & 821.7 & 830.4 & 838.9 & 840.0 & 852.0 \\
\hline 19 & Life insurance companies ........... & $2,488.3$ & $2,661.4$ & $2,765.4$ & $2,806.1$ & $2,842.5$ & $2,806.1$ & $2,831.7$ & $2,855.7$ & $2,882.2$ & $2,890.8$ & $2,915.5$ \\
\hline 20 & Private pension funds.... & 646.5 & 646.1 & 690.6 & 704.6 & 694.2 & 704.6 & 712.3 & 722.2 & 734.7 & 738.2 & 746.1 \\
\hline 21 & State and local government retirement funds ... & 657.5 & 675.3 & 693.4 & 769.7 & 758.7 & 769.7 & 767.5 & 772.2 & 787.5 & 799.8 & 810.5 \\
\hline 22 & Federal government retirement funds...$\ldots \ldots \ldots$. & 63.6 & 68.2 & 76.0 & 84.3 & 83.7 & 84.3 & 88.1 & 88.9 & 93.3 & 96.1 & 106.1 \\
\hline 23 & Money market mutual funds $\ldots \ldots \ldots \ldots \ldots \ldots \ldots$ & $1,471.3$ & $1,346.3$ & $1,340.8$ & $1,560.8$ & $1,461.2$ & $1,560.8$ & $1,649.5$ & $1,699.7$ & $1,802.7$ & $1,951.5$ & $2,253.4$ \\
\hline 24 & Mutual funds & $1,506.4$ & $1,623.0$ & $1,747.1$ & $1,932.0$ & $1,874.0$ & $1,932.0$ & $2,005.4$ & $2,093.5$ & $2,141.6$ & $2,203.1$ & $2,269.2$ \\
\hline 25 & Closed-end funds & 152.6 & 163.6 & 165.1 & 171.8 & 170.4 & 171.8 & 171.6 & 175.1 & 170.6 & 172.0 & 170.5 \\
\hline 26 & Exchange-traded funds & 4.5 & 8.2 & 15.0 & 20.7 & 18.7 & 20.7 & 22.4 & 26.3 & 28.7 & 33.5 & 37.8 \\
\hline 27 & Government-sponsored enterprises & $2,564.2$ & $2,613.0$ & $2,543.9$ & $2,590.5$ & $2,579.0$ & $2,590.5$ & $2,558.4$ & $2,596.7$ & $2,758.9$ & $2,829.5$ & $2,893.4$ \\
\hline 28 & Agency- and GSE-backed mortgage pools . ...... & $3,326.7$ & $3,374.6$ & $3,541.9$ & $3,837.3$ & $3,763.1$ & $3,837.3$ & $3,955.7$ & $4,075.8$ & $4,243.2$ & $4,463.7$ & $4,594.6$ \\
\hline 29 & Asset-backed securities (ABSs) issuers . . . . . . . & $2,081.5$ & $2,497.7$ & $3,171.3$ & $3,897.1$ & $3,709.2$ & $3,897.1$ & $4,041.2$ & $4,169.2$ & $4,201.0$ & $4,145.7$ & $4,071.0$ \\
\hline 30 & Finance companies $\ldots \ldots \ldots \ldots \ldots$. & $1,204.9$ & $1,419.8$ & $1,537.1$ & $1,626.8$ & $1,608.2$ & $1,626.8$ & $1,617.6$ & $1,615.8$ & $1,637.0$ & $1,636.6$ & $1,634.5$ \\
\hline 31 & Real estate investment trusts (REITs). & 97.5 & 200.1 & 267.0 & 324.5 & 302.7 & 324.5 & 315.4 & 303.2 & 269.3 & 271.4 & 261.6 \\
\hline 32 & Brokers and dealers $\ldots \ldots \ldots \ldots \ldots \ldots$ & 424.1 & 394.9 & 477.2 & 583.4 & 537.3 & 583.4 & 677.2 & 583.8 & 718.2 & 803.1 & 869.6 \\
\hline & Funding corporations & 152.0 & 198.9 & 246.4 & 279.9 & 256.4 & 279.9 & 278.8 & 326.4 & 299.8 & 182.9 & 262.1 \\
\hline & $\begin{array}{l}\text { RELATION OF Liabilities } \\
\text { TO FINANCIAL ASSETS }\end{array}$ & & & & & & & & & & & \\
\hline 34 & Total credit market debt & $34,460.9$ & $37,604.5$ & $40,944.6$ & $44,814.9$ & $43,802.4$ & $44,814.9$ & $45,711.5$ & $46,605.1$ & $47,856.7$ & $48,857.2$ & $49,614.4$ \\
\hline & Other liabilities & & & & & & & & & & & \\
\hline 35 & Official foreign exch & 62.3 & 62.2 & 45.9 & 46.0 & 46.5 & 46.0 & 46.6 & 46.1 & 48.7 & 50.0 & 54.8 \\
\hline 36 & Special drawing rights certificates & 2.2 & 2.2 & 2.2 & 2.2 & 2.2 & 2.2 & 2.2 & 2.2 & 2.2 & 2.2 & 2.2 \\
\hline 37 & Treasury currency $\ldots \ldots \ldots \ldots \ldots \ldots \ldots$ & 26.0 & 26.7 & 27.5 & 28.1 & 28.1 & 28.1 & 28.2 & 28.5 & 28.8 & 28.7 & 28.5 \\
\hline 38 & Foreign deposits & 867.1 & 957.0 & $1,024.7$ & $1,123.5$ & $1,139.6$ & $1,123.5$ & $1,194.7$ & $1,293.5$ & $1,339.9$ & $1,350.3$ & $1,362.8$ \\
\hline 39 & Net interbank liabilities & 193.0 & 212.2 & 201.3 & 190.0 & 147.5 & 190.0 & 50.5 & 65.6 & 112.6 & 147.1 & 73.0 \\
\hline 40 & Checkable deposits and currency & $1,436.9$ & $1,521.7$ & $1,525.2$ & $1,506.5$ & $1,491.1$ & $1,506.5$ & $1,501.4$ & $1,498.5$ & $1,499.6$ & $1,535.9$ & $1,526.5$ \\
\hline 41 & Small time and savings deposits & $4,003.3$ & $4,284.9$ & $4,599.3$ & $4,946.3$ & $4,792.1$ & $4,946.3$ & $5,076.1$ & $5,111.9$ & $5,165.1$ & $5,232.6$ & $5,381.0$ \\
\hline 42 & Large time deposits .......... & $1,226.8$ & $1,505.1$ & $1,789.5$ & $2,050.8$ & $2,055.9$ & $2,050.8$ & $2,118.9$ & $2,146.5$ & $2,282.0$ & $2,370.4$ & $2,448.9$ \\
\hline 43 & Mo & $2,016.4$ & $1,879.8$ & $2,006.9$ & $2,312.1$ & $2,168.2$ & $2,312.1$ & $2,389.7$ & $2,489.7$ & $2,801.6$ & $3,053.2$ & $3,407.8$ \\
\hline 44 & Irchase agreements ..... & $1,559.1$ & $1,647.2$ & $1,998.0$ & $2,494.0$ & $2,368.2$ & $2,494.0$ & $2,678.4$ & $2,727.8$ & $2,789.4$ & $2,588.1$ & $2,623.4$ \\
\hline 45 & d shares $\ldots \ldots \ldots \ldots \ldots \ldots \ldots \ldots$ & $4,654.2$ & $5,436.3$ & $6,048.9$ & $7,068.3$ & $6,627.9$ & $7,068.3$ & $7,328.7$ & $7,805.2$ & $7,989.3$ & $7,829.0$ & $7,271.7$ \\
\hline 46 & Security credit & 858.8 & $1,038.2$ & $1,038.4$ & $1,249.9$ & $1,191.5$ & $1,249.9$ & $1,289.0$ & $1,379.5$ & $1,374.5$ & $1,526.4$ & $1,618.1$ \\
\hline 47 & Life insurance $r$ & $1,013.2$ & $1,060.4$ & $1,082.6$ & $1,163.7$ & $1,133.5$ & $1,163.7$ & $1,172.7$ & $1,191.1$ & $1,199.6$ & $1,201.5$ & $1,184.0$ \\
\hline 48 & Pension fund reserves .... & $9,722.4$ & $10,632.6$ & $11,368.9$ & $12,301.6$ & $11,772.2$ & $12,301.6$ & $12,408.3$ & $12,867.6$ & $12,980.1$ & $12,764.9$ & $12,162.6$ \\
\hline 49 & Trade payables $\ldots \ldots \ldots \ldots \ldots \ldots \ldots \ldots \ldots$ & $2,465.3$ & $2,659.7$ & $2,996.3$ & $3,217.0$ & $3,159.7$ & $3,217.0$ & $3,282.2$ & $3,369.8$ & $3,441,4$ & $3,500.6$ & $3,561.1$ \\
\hline 50 & Taxes payable. & 240.4 & 268.9 & 297.0 & 316.9 & 323.1 & 316.9 & 335.4 & 336.9 & 348.2 & 341.0 & 358.3 \\
\hline 51 & Miscellaneous .... & $12,423.3$ & $13,914.7$ & $14,897.7$ & $16,089.5$ & $15,320.4$ & $16,089.5$ & $16,250.8$ & $16,513.6$ & $16,886.6$ & $16,815.4$ & $17,387.6$ \\
\hline 52 & Total liabilities & $77,231.3$ & $84,714.1$ & $91,894.8$ & $100,921.3$ & $97,570.0$ & $100,921.3$ & $102,865.1$ & $105,479.3$ & $108,146.5$ & $109,194.7$ & $110,066.6$ \\
\hline & Financial assets not included in liabilities (+) & & & & & & & & & & & \\
\hline 53 & ecial drawing rights & 23.7 & 24.6 & 19.3 & 19.9 & 19.7 & 19.9 & 20.0 & 20.1 & 20.3 & 20.5 & 20.9 \\
\hline 54 & Corporate equities & $15,618.5$ & $17,389.3$ & $18,512.0$ & $20,909.3$ & $19,595.7$ & $20,909.3$ & $21,133.9$ & $22,208.5$ & $22,429.6$ & $21,477.2$ & $19,360.8$ \\
\hline 55 & Household equity in noncorporate business & $5,393.3$ & $5,981.3$ & $6,641.6$ & $7,303.7$ & $7,168.8$ & $7,303.7$ & $7,510.3$ & $7,687.4$ & $7,810.4$ & $7,892.1$ & $7,934.7$ \\
\hline & tentified as assets (-) & & & & & & & & & & & \\
\hline 56 & Treasury currency & -9.5 & -9.7 & -9.1 & -10.1 & -10.0 & -10.1 & -10.2 & -10.0 & -9.8 & -9.9 & -10.2 \\
\hline 57 & Foreig & 705.3 & 767.2 & 807.9 & 922.2 & 956.7 & 922.2 & 996.4 & $1,090.7$ & $1,103.0$ & $1,088.1$ & $1,085.3$ \\
\hline 58 & Net in & 12.7 & 27.3 & 25.2 & 23.2 & 41.4 & 23.2 & 33.0 & 19.9 & 20.8 & 21.7 & 15.0 \\
\hline 59 & Security repurchase agreements $\ldots \ldots \ldots \ldots \ldots$ & 392.7 & 248.3 & 382.4 & 474.1 & 374.4 & 474.1 & 475.2 & 479.8 & 527.8 & 269.5 & 287.6 \\
\hline 60 & 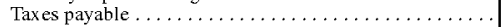 & 69.2 & 97.0 & 96.7 & 53.0 & 58.8 & 53.0 & 58.8 & 55.3 & 43.7 & 26.3 & 2.9 \\
\hline 61 & Miscellaneous ......... & $-3,471.3$ & $-3,536.2$ & $-3,702.5$ & $-4,500.9$ & $-4,341.2$ & $-4,500.9$ & $-4,890.6$ & $-5,060.1$ & $-5,261.9$ & $-5,561.9$ & $-5,739.2$ \\
\hline & & & & & & & & & & & & \\
\hline 62 & Federal government checkable deposits & -17.9 & 11.2 & 1.8 & .1 & 2.7 & .1 & 1.3 & -.8 & .8 & 2.8 & 8.9 \\
\hline 63 & Other checkable deposits . . . . . . . . . & 20.8 & 20.0 & 19.2 & 11.4 & 10.4 & 11.4 & 10.0 & 10.0 & 6.4 & 10.3 & 11.2 \\
\hline 64 & Trade credit .. & 23.3 & 32.7 & .9 & 100.8 & -12.8 & 100.8 & 100.5 & 58.7 & 76.2 & 156.4 & 91.4 \\
\hline 65 & Totals identified to sectors as assets & $100,541.3$ & $110,451.6$ & $119,445.1$ & $132,080.6$ & $127,273.9$ & $132,080.6$ & $134,754.9$ & $138,751.9$ & $141,899.9$ & $142,581.2$ & $141,629.9$ \\
\hline
\end{tabular}

1. Data in this table also appear in the Board's Z.1 quarterly statistical release, tables L.1

2. Excludes corporate equities and mutual fund shares.

and $L .5$, available at $w w w$.federalreserve.gov/releases. 


\subsection{OUTPUT, CAPACITY, AND CAPACITY UTILIZATION $^{1}$}

Seasonally adjusted

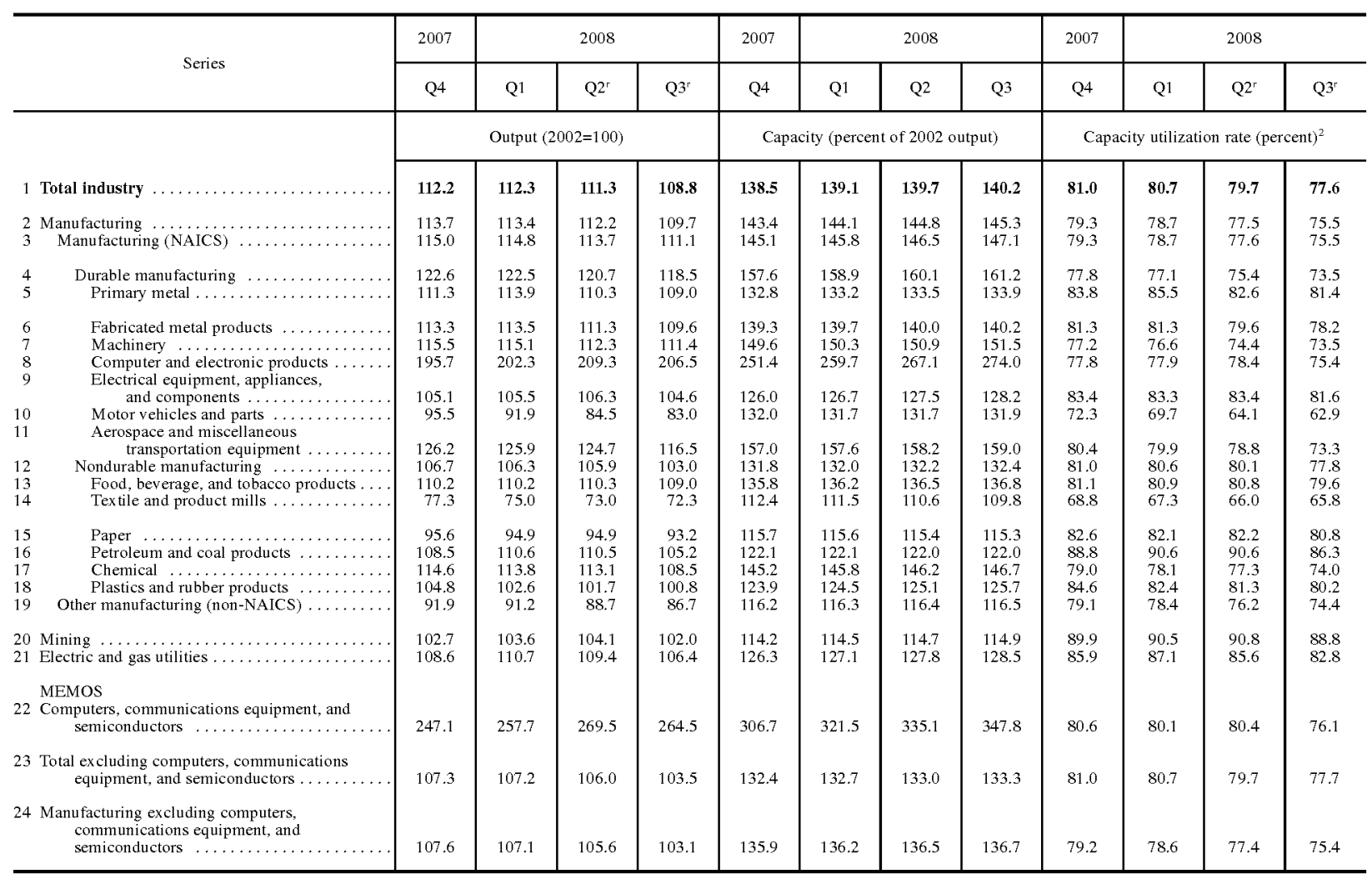


2.12 OUTPUT, CAPACITY, AND CAPACITY UTILIZATION ${ }^{1}$ - CONTINUED

Seasonally adjusted

\begin{tabular}{|c|c|c|c|c|c|c|c|c|c|c|c|c|c|c|}
\hline \multirow{2}{*}{\multicolumn{2}{|c|}{ Series }} & \multirow{2}{*}{$\begin{array}{c}1973 \\
\text { High }\end{array}$} & \multirow{2}{*}{$\frac{1975}{\text { Low }}$} & \multicolumn{2}{|c|}{ Previous cycle ${ }^{2}$} & \multicolumn{2}{|c|}{ Latest cycle ${ }^{3}$} & \multirow{2}{*}{$\begin{array}{l}2007 \\
\text { Noy. }\end{array}$} & \multicolumn{6}{|c|}{2008} \\
\hline & & & & High & Low & High & Low & & Juner & July & Aug. ${ }^{r}$ & Sept. ${ }^{r}$ & Oct. $^{r}$ & Nove ${ }^{p}$ \\
\hline \multirow{2}{*}{\multicolumn{2}{|c|}{1 Total industry $\ldots \ldots \ldots \ldots \ldots \ldots$}} & \multicolumn{13}{|c|}{ Capacity utilization rate (percent) ${ }^{4}$} \\
\hline & & 88.8 & 74.0 & 86.6 & 70.9 & 85.0 & 78.6 & 81.1 & 79.6 & 79.5 & 78.3 & 75.0 & 76.0 & 75.4 \\
\hline 2 & Manufacturing & 88.3 & 71.5 & 86.2 & 68.5 & 85.4 & 77.1 & 79.3 & 77.3 & 77.1 & 76.2 & 73.1 & 73.4 & 72.3 \\
\hline 3 & Manufacturing (NAICS) & 88.4 & 71.3 & 86.2 & 67.8 & 85.3 & 77.0 & 79.3 & 77.4 & 77.2 & 76.3 & 73.0 & 73.4 & 72.2 \\
\hline 4 & Durable manufacturing & 89.4 & 69.6 & 86.7 & 62.9 & 84.6 & 73.5 & 77.9 & 75.3 & 75.3 & 73.9 & 71.3 & 69.6 & 68.5 \\
\hline 5 & Primary metal $\ldots . .$. & 101.9 & 69.8 & 90.1 & 46.9 & 93.8 & 75.0 & 83.5 & 82.2 & 83.7 & 82.4 & 78.1 & 71.8 & 66.4 \\
\hline 6 & Fabricated metal products. & 91.7 & 69.9 & 83.1 & 61.8 & 81.7 & 72.7 & 81.6 & 78.6 & 78.3 & 78.6 & 77.7 & 76.3 & 74.5 \\
\hline 7 & Machinery ............ & 94.6 & 74.3 & 92.7 & 58.0 & 85.3 & 74.0 & 77.1 & 74.2 & 73.5 & 74.6 & 72.5 & 70.9 & 69.2 \\
\hline 8 & $\begin{array}{l}\text { Computer and electronic } \\
\text { products } \ldots \ldots \ldots\end{array}$ & 87.0 & 660 & 90.0 & 77.4 & 819 & 767 & 780 & 778 & 769 & 755 & 737 & 724 & 709 \\
\hline \multirow[t]{2}{*}{9} & $\begin{array}{c}\text { Electrical equipment, } \\
\text { appliances, and }\end{array}$ & 0.0 & 00.0 & 90.0 & 11.4 & 81.9 & 10.7 & 10.0 & 71.0 & 10.9 & 75.5 & 13.1 & 12.4 & 70.9 \\
\hline & components ... & 99.3 & 68.0 & 91.9 & 64.6 & 89.1 & 77.0 & 83.4 & 83.6 & 83.2 & 82.3 & 79.3 & 79.3 & 77.4 \\
\hline \multirow{3}{*}{$\begin{array}{l}10 \\
11\end{array}$} & Motor vehicles and parts ..... & 95.8 & 54.8 & 95.1 & 44.9 & 89.5 & 56.0 & 72.6 & 65.9 & 67.7 & 60.2 & 60.9 & 58.7 & 57.0 \\
\hline & $\begin{array}{l}\text { Aerospace and } \\
\text { miscellaneous }\end{array}$ & & & & & & & & & & & & & \\
\hline & transportation equipment & 75.9 & 68.1 & 87.1 & 69.0 & 87.4 & 81.0 & 80.8 & 79.2 & 78.1 & 77.5 & 64.1 & 62.0 & 69.8 \\
\hline \multirow[t]{2}{*}{$\begin{array}{l}12 \\
13\end{array}$} & $\begin{array}{l}\text { Nondurable manufacturing ...... } \\
\text { Food, beverage, and tobacco }\end{array}$ & 87.6 & 72.3 & 85.8 & 75.4 & 86.7 & 81.4 & 80.9 & 79.7 & 79.4 & 78.9 & 75.0 & 77.6 & 76.3 \\
\hline & products ............. & 86.3 & 77.5 & 84.2 & 80.4 & 86.0 & 80.9 & 81.0 & 80.4 & 79.9 & 79.7 & 79.3 & 80.0 & 80.0 \\
\hline 14 & Textile and product mills ..... & 89.5 & 61.8 & 89.6 & 72.1 & 91.1 & 77.6 & 68.6 & 65.6 & 65.9 & 66.6 & 65.0 & 64.7 & 62.8 \\
\hline 15 & Paper & 96.7 & 74.1 & 95.4 & 81.4 & 92.6 & 86.1 & 82.4 & 82.0 & 81.3 & 82.0 & 79.2 & 77.7 & 76.2 \\
\hline 16 & Petroleum and coal products & 92.1 & 80.8 & 91.0 & 68.8 & 88.2 & 82.4 & 88.5 & 90.2 & 90.4 & 89.0 & 79.4 & 87.9 & 87.9 \\
\hline 17 & Chemical $\ldots \ldots \ldots \ldots \ldots$. & 85.3 & 69.1 & 83.5 & 67.9 & 85.0 & 79.9 & 79.0 & 77.0 & 76.7 & 75.8 & 69.5 & 73.9 & 71.2 \\
\hline 18 & Plastics and rubber products .. & 96.1 & 61.7 & 90.1 & 71.8 & 89.8 & 76.4 & 85.0 & 81.7 & 81.8 & 80.2 & 78.6 & 76.7 & 74.3 \\
\hline 19 & Other manufacturing (non-NAICS) & 86.2 & 75.6 & 88.0 & 86.7 & 91.1 & 80.4 & 79.0 & 76.0 & 74.9 & 74.4 & 74.0 & 74.3 & 73.8 \\
\hline & Mining & 93.4 & 87.6 & 93.8 & 79.6 & 86.3 & 83.6 & 90.0 & 90.9 & 92.1 & 91.5 & 82.8 & 88.7 & 90.9 \\
\hline & Electric and gas utilities ........... & 96.2 & 82.9 & 89.0 & 77.7 & 92.7 & 84.1 & 86.3 & 85.9 & 84.9 & 80.9 & 82.7 & 83.1 & 84.3 \\
\hline \multirow{2}{*}{22} & MEMOS & & & & & & & & & & & & & \\
\hline & $\begin{array}{l}\text { Computers, communications } \\
\text { equipment, and semiconductors. }\end{array}$ & 84.4 & 62.3 & 89.6 & 75.1 & 81.7 & 75.3 & 80.7 & 79.4 & 78.1 & 76.1 & 74.0 & 72.1 & 69.9 \\
\hline \multirow{2}{*}{\multicolumn{2}{|c|}{$\begin{array}{l}23 \text { Total excluding computers, } \\
\text { communications equipment, } \\
\text { and semiconductors .......... } \\
24 \text { Manufacturing excluding computers, } \\
\text { communications } \\
\text { equipment, and semiconductors. }\end{array}$}} & 89.1 & 74.4 & 86.8 & 70.6 & 85.3 & 78.7 & 81.1 & 79.6 & 79.5 & 78.4 & 75.0 & 76.2 & 75.7 \\
\hline & & 88.4 & 71.9 & 86.4 & 68.0 & 85.8 & 77.2 & 79.2 & 77.2 & 77.1 & 76.2 & 73.0 & 73.5 & 72.4 \\
\hline
\end{tabular}

NoTE: The statistics in this release cover output, capacity, and capacity utilization in the industrial sector, which is defined by the Federal Reserve to comprise manufacturing, mining, and electric and gas utilities. Mining is defined as all industries in sector 21 of the North American Industry Classification System, or NAICS; electric and gas utilities are those in NAICS sectors 2211 and 2212. Manufacturing comprises NAICS industries (sector 31-33) plus the loging industry and the newspaper periodical, book and directory publishing plus the log infortion resper information respectively), but historically they were considered to be nanufacturing and were included in the ind the system. In December 2002, the Federal Reserve reclassified all its industrial output data from the SIC
system to NAICS.

1. Data in this table appear in the Board's G.17(419) monthly statistical release. The data are also available on the Board's website, www federalreserve gov/releases/g17. The latest historical revision of the industrial production index and the capacity utilization rates was released on March 28,2008. The 2008 annual revision is described in an article in the Federal Reseve Bulletin titled "Industrial Production and Capacity Utilization: The 2008 Revision," www.federalreserve.gov/pubs/bulletin/2008/pdf/Industrial08.pdf

2. Monthly highs, 1978-80; monthly lows, 1982 .

3. Monthly highs, 1988-89; monthly lows, 1990-91.

4. Capacity utilization is calculated as the ratio of the Federal Reserve's seasonally adjusted index of industrial production to the corresponding index of capacity. 
2.13 INDUSTRIAL PRODUCTION Indexes and Gross Value

Monthly data seasonally adjusted

\begin{tabular}{|c|c|c|c|c|c|c|c|c|c|c|c|c|c|c|c|c|}
\hline \multirow{2}{*}{\multicolumn{2}{|c|}{ Group }} & \multirow{2}{*}{$\begin{array}{l}2002 \\
\text { pro- } \\
\text { por- } \\
\text { tion }\end{array}$} & \multirow{2}{*}{$\begin{array}{l}2007 \\
\text { avg. }\end{array}$} & \multicolumn{2}{|c|}{2007} & \multicolumn{11}{|c|}{2008} \\
\hline & & & & Noy. & Dec. & Jan. & Feb. & Mar. & Apr. & May & Juner & Julyr & Aug. ${ }^{r}$ & Sept ${ }^{r}$ & Oct. $^{r}$ & Nov. ${ }^{p}$ \\
\hline \multicolumn{17}{|c|}{ Index $(2002=100)$} \\
\hline \multicolumn{17}{|c|}{ MAJOR MARKETS } \\
\hline 1 & Total IP & 100.0 & 111.4 & 112.3 & 112.4 & 112.6 & 112.3 & 112.0 & 111.4 & 111.2 & 111.3 & 111.3 & 109.8 & 105.2 & 106.8 & 106.1 \\
\hline \multicolumn{17}{|c|}{ Market groups } \\
\hline 2 & Final products and nonindustrial supplies & 58.5 & 111.5 & 111.8 & 111.9 & 112.3 & 112.0 & 111.4 & 110.8 & 110.5 & 110.7 & 110.6 & 109.0 & 106.1 & 106.6 & 106.3 \\
\hline 3 & Consumer goods $\ldots \ldots \ldots \ldots \ldots \ldots$ & 30.8 & 107.5 & 107.4 & 107.4 & 108.0 & 107.9 & 106.7 & 106.2 & 105.8 & 106.2 & 106.2 & 103.9 & 102.4 & 104.0 & 103.3 \\
\hline 4 & Durable.... & 8.9 & 103.2 & 102.9 & 102.7 & 101.1 & 100.0 & 97.8 & 94.5 & 94.9 & 96.7 & 97.4 & 91.3 & 90.3 & 88.2 & 85.5 \\
\hline 5 & Automotive products & 4.7 & 100.9 & 101.1 & 101.6 & 99.6 & 98.5 & 93.8 & 87.2 & 87.9 & 92.3 & 93.6 & 83.2 & 84.4 & 81.4 & 79.3 \\
\hline 6 & Home electronics ... & .4 & 155.8 & 167.6 & 170.1 & 167.7 & 168.1 & 169.7 & 177.4 & 179.9 & 174.2 & 179.4 & 175.3 & 168.0 & 165.9 & 163.0 \\
\hline 7 & Appliances, furniture, carpeting & 1.4 & 96.0 & 92.9 & 91.7 & 89.1 & 87.3 & 87.3 & 86.9 & 86.3 & 85.4 & 84.9 & 81.5 & 78.0 & 76.7 & 73.7 \\
\hline 8 & Miscellaneous goods $\ldots \ldots \ldots \ldots$ & 2.4 & 104.0 & 103.2 & 102.3 & 101.9 & 100.9 & 101.4 & 100.8 & 100.9 & 100.8 & 100.8 & 99.8 & 97.6 & 96.2 & 92.9 \\
\hline 9 & Nondurable $\ldots \ldots \ldots \ldots \ldots \ldots$ & 21.9 & 108.8 & 108.8 & 108.8 & 110.1 & 110.4 & 109.5 & 109.8 & 109.1 & 109.1 & 108.9 & 107.8 & 106.1 & 108.8 & 108.7 \\
\hline 10 & Non-energy & 18.1 & 109.1 & 108.8 & 109.2 & 109.3 & 109.1 & 109.5 & 109.1 & 109.2 & 109.0 & 108.7 & 108.6 & 108.4 & 108.8 & 108.6 \\
\hline 11 & Foods and tobacco & 9.7 & 109.9 & 109.5 & 109.6 & 109.3 & 109.2 & 110.2 & 109.8 & 109.9 & 109.2 & 108.7 & 108.5 & 108.2 & 109.2 & 109.1 \\
\hline 12 & Clothing . . . . . . & .9 & 78.0 & 76.2 & 78.0 & 77.2 & 76.5 & 75.3 & 74.8 & 73.7 & 75.0 & 75.6 & 76.3 & 75.2 & 73.1 & 73.0 \\
\hline 13 & Chemical products & 5.0 & 117.6 & 118.0 & 118.5 & 119.1 & 119.0 & 118.1 & 118.7 & 118.7 & 119.0 & 119.4 & 118.9 & 119.4 & 119.3 & 118.9 \\
\hline 14 & Paper products ... & 2.0 & 96.2 & 95.2 & 95.9 & 96.5 & 96.6 & 97.2 & 94.9 & 95.2 & 95.8 & 94.5 & 94.5 & 93.8 & 94.2 & 93.6 \\
\hline 15 & Energy $\ldots \ldots \ldots \ldots$ & 3.9 & 108.4 & 109.0 & 108.1 & 112.6 & 113.8 & 109.7 & 111.7 & 109.4 & 109.8 & 109.6 & 106.3 & 101.2 & 109.0 & 109.2 \\
\hline 16 & Business equipment & 10.2 & 128.4 & 130.2 & 131.2 & 131.4 & 131.1 & 132.3 & 130.0 & 130.4 & 130.4 & 129.8 & 129.3 & 119.9 & 116.8 & 120.6 \\
\hline 17 & Transit $\ldots \ldots \ldots$ & 1.8 & 124.2 & 123.2 & 123.9 & 122.5 & 121.1 & 120.7 & 118.1 & 118.6 & 120.1 & 120.6 & 115.4 & 76.0 & 67.7 & 95.6 \\
\hline 18 & Information processing & 3.1 & 155.6 & 162.7 & 164.8 & 165.2 & 167.5 & 169.9 & 172.0 & 172.8 & 172.6 & 169.6 & 167.8 & 166.1 & 165.5 & 164.3 \\
\hline 19 & Industrial and other .. & 5.3 & 115.7 & 116.2 & 116.7 & 117.4 & 116.5 & 117.6 & 113.8 & 114.0 & 113.5 & 113.6 & 115.0 & 112.6 & 110.3 & 108.2 \\
\hline 20 & Defense and space equipment & 1.8 & 117.1 & 120.2 & 119.9 & 120.9 & 119.6 & 119.6 & 119.5 & 119.0 & 120.3 & 119.0 & 119.2 & 116.4 & 117.8 & 117.7 \\
\hline 21 & Construction supplies & 4.3 & 106.0 & 104.5 & 104.2 & 103.6 & 102.3 & 102.3 & 101.4 & 101.7 & 101.3 & 101.9 & 100.9 & 99.0 & 97.6 & 94.4 \\
\hline 22 & Business supplies .... & 11.0 & 108.7 & 109.2 & 108.9 & 109.3 & 109.2 & 108.5 & 108.6 & 107.9 & 107.5 & 107.4 & 106.6 & 103.5 & 104.4 & 103.4 \\
\hline 23 & Materials & 41.5 & 111.3 & 113.0 & 113.1 & 113.0 & 112.6 & 112.8 & 112.3 & 112.2 & 112.1 & 112.2 & 110.7 & 104.2 & 107.0 & 106.0 \\
\hline 24 & Non-energy & 30.5 & 115.5 & 117.2 & 116.9 & 116.7 & 116.0 & 116.4 & 115.7 & 115.4 & 115.4 & 115.0 & 113.8 & 107.9 & 108.9 & 105.4 \\
\hline 25 & Durable. & 19.0 & 123.5 & 126.4 & 125.8 & 126.0 & 126.0 & 126.4 & 125.7 & 125.0 & 125.4 & 125.4 & 123.9 & 121.3 & 118.5 & 114.9 \\
\hline 26 & Consumer parts & 4.0 & 93.7 & 92.9 & 90.7 & 90.1 & 89.1 & 87.6 & 86.0 & 85.7 & 86.4 & 87.0 & 81.5 & 81.0 & 77.8 & 75.0 \\
\hline 27 & Equipment parts ... & 6.6 & 167.1 & 176.5 & 176.7 & 178.3 & 179.9 & 182.8 & 182.3 & 181.6 & 182.4 & 182.2 & 182.8 & 178.9 & 176.7 & 173.2 \\
\hline 28 & Other.$\ldots \ldots \ldots$ & 8.4 & 109.1 & 110.4 & 110.0 & 109.8 & 109.6 & 109.5 & 109.2 & 108.4 & 108.4 & 108.3 & 107.6 & 104.9 & 102.2 & 98.5 \\
\hline 29 & Nondurable & 11.5 & 103.5 & 103.5 & 103.7 & 103.1 & 101.4 & 101.8 & 101.1 & 101.2 & 100.8 & 99.9 & 99.1 & 89.6 & 94.8 & 91.7 \\
\hline 30 & Textile. & .8 & 76.6 & 73.1 & 72.6 & 71.0 & 71.0 & 69.6 & 68.9 & 69.2 & 67.4 & 67.8 & 69.6 & 67.1 & 66.4 & 63.6 \\
\hline 31 & Paper & 2.7 & 97.7 & 97.7 & 99.3 & 97.8 & 95.9 & 96.6 & 95.8 & 97.8 & 95.1 & 94.5 & 94.6 & 92.5 & 91.9 & 90.4 \\
\hline 32 & Chemical & 4.5 & 112.4 & 112.5 & 112.3 & 111.9 & 109.9 & 109.7 & 109.4 & 109.1 & 108.9 & 108.0 & 106.0 & 87.5 & 99.5 & 94.1 \\
\hline 33 & Energy $\ldots \ldots$ & 11.0 & 101.6 & 103.3 & 104.1 & 104.2 & 104.5 & 104.3 & 104.1 & 104.2 & 104.1 & 104.9 & 103.1 & 95.6 & 101.5 & 104.4 \\
\hline \multicolumn{17}{|c|}{ SPECIAL AgGREGATES } \\
\hline 34 & $\begin{array}{l}\text { Total excluding computers, communication } \\
\text { equipment, and semiconductors ...... }\end{array}$ & 94.6 & 107.0 & 107.4 & 107.4 & 107.6 & 107.2 & 106.8 & 106.1 & 105.9 & 105.9 & 105.9 & 104.5 & 100.1 & 101.7 & 101.1 \\
\hline \multirow[t]{2}{*}{35} & Total excluding motor vehicles and parts . & 92.6 & 112.3 & 113.4 & 113.5 & 113.8 & 113.5 & 113.5 & 113.2 & 113.0 & 112.8 & 112.7 & 111.7 & 106.8 & 108.6 & 108.1 \\
\hline & & \multicolumn{15}{|c|}{ Gross value (billions of 2000 dollars, annual rates) } \\
\hline 36 & $\begin{array}{l}\text { Final products and nonind ustrial } \\
\text { supplies } \ldots \ldots \ldots \ldots \ldots \ldots\end{array}$ & 58.5 & $3,034.7$ & $3,041.3$ & $3,043.1$ & $3,062.1$ & $\mid 3,051.2$ & $3,026.8$ & $3,005.6$ & $2,998.4$ & $3,004.3$ & 3,011.1 & $2,953.1$ & $2,850.8$ & $2,892.3$ & $2,881.0$ \\
\hline 37 & Final products & 43.1 & $2,311.5$ & $2,318.1$ & $2,321.0$ & $2,337.6$ & $2,330.6$ & $2,310.5$ & $2,288.1$ & $2,283.6$ & $2,292.0$ & $2,296.3$ & $2,244.7$ & $2,167.7$ & $2,205.4$ & $2,204.2$ \\
\hline 38 & Consumer goods & 30.8 & $1,606.3$ & $1,606.9$ & $1,605.5$ & $1,621.4$ & $1,616.8$ & $1,593.9$ & $1,581.4$ & $1,576.3$ & $1,583.0$ & $1,588.4$ & $1,544.8$ & $1,507.1$ & $1,551.3$ & $1,537.9$ \\
\hline 39 & Equipment total & 12.3 & 715.4 & 722.4 & 728.0 & 727.2 & 724.7 & 730.7 & 719.5 & 720.8 & 722.2 & 720.1 & 715.2 & 668.8 & 654.4 & 672.3 \\
\hline 40 & Nonindustrial supplies . & 15.4 & 724.5 & 724.7 & 723.6 & 726.2 & 722.4 & 717.9 & 718.8 & 716.1 & 713.9 & 716.3 & 709.4 & 684.1 & 688.4 & 678.7 \\
\hline
\end{tabular}


2.13 INDUSTRIAL PRODUCTION Indexes and Gross Value'-Continued

Monthly data seasonally adjusted

\begin{tabular}{|c|c|c|c|c|c|c|c|c|c|c|c|c|c|c|c|c|c|}
\hline \multirow{2}{*}{\multicolumn{2}{|c|}{ Group }} & \multirow{2}{*}{$\begin{array}{l}\text { NAICS } \\
\text { code }^{2}\end{array}$} & \multirow{2}{*}{$\begin{array}{l}2002 \\
\text { pro- } \\
\text { por- } \\
\text { tion }\end{array}$} & \multirow{2}{*}{$\begin{array}{l}2007 \\
\text { avg. }\end{array}$} & \multicolumn{2}{|c|}{2007} & \multicolumn{11}{|c|}{2008} \\
\hline & & & & & Noy. & Dec. & Jan. & Feb. & Mar. & Apr. & May & Juner & July $y^{r}$ & Aug. ${ }^{r}$ & Sept. ${ }^{r}$ & Oct. $^{r}$ & Nove \\
\hline & & & & & & & & & & Inde & $(2002=$ & 00) & & & & & \\
\hline \multicolumn{18}{|c|}{ INDUSTRY GROUPS } \\
\hline 41 & Manufacturing & & 83.2 & 112.9 & 113.8 & 113.8 & 113.8 & 113.1 & 113.3 & 112.3 & 112.3 & 112.1 & 111.9 & 110.8 & 106.3 & 107.0 & 105.5 \\
\hline 42 & Manufacturing (NAICS) & $\ldots$ & 78.5 & 114.2 & 115.1 & 115.1 & 115.2 & 114.5 & 114.6 & 113.7 & 113.7 & 113.5 & 113.4 & 112.2 & 107.6 & 108.3 & 106.7 \\
\hline 43 & Durable manufacturing & & 43.2 & 121.0 & 122.9 & 122.8 & 122.9 & 122.2 & 122.4 & 120.7 & 120.6 & 120.9 & 121.1 & 119.2 & 115.3 & 112.7 & 111.2 \\
\hline 44 & Wood products .... & 321 & 1.5 & 99.2 & 94.2 & 94.3 & 92.3 & 91.0 & 91.4 & 90.2 & 89.6 & 89.0 & 88.0 & 87.3 & 84.3 & 79.8 & 78.1 \\
\hline 45 & $\begin{array}{c}\text { Nonmetallic mineral } \\
\text { products }\end{array}$ & 327 & 2.3 & 108.1 & 109.7 & 105.9 & 106.1 & 104.9 & 106.5 & 104.9 & 105.0 & 103.8 & 105.1 & 104.1 & 101.4 & 102.1 & 98.4 \\
\hline 46 & Primary metal ....... & 331 & 2.3 & 110.3 & 111.0 & 112.9 & 115.2 & 114.1 & 112.3 & 111.5 & 109.5 & 109.9 & 112.0 & $\begin{array}{l}104.1 \\
110.3\end{array}$ & $\begin{array}{l}101.4 \\
104.6\end{array}$ & $\begin{array}{r}102.1 \\
96.3\end{array}$ & $\begin{array}{l}98.4 \\
89.1\end{array}$ \\
\hline 47 & Fabricated metal products & 332 & 5.7 & 112.0 & 113.7 & 113.1 & 113.4 & 113.5 & 113.6 & 112.4 & 111.5 & 110.1 & 109.7 & 110.2 & 108.9 & 107.0 & 104.6 \\
\hline 48 & Machinery...$\ldots \ldots$ & 333 & 5.3 & 116.0 & 115.4 & 114.6 & 115.2 & 114.1 & 116.0 & 112.4 & 112.3 & 112.1 & 111.1 & 112.9 & 110.0 & 107.7 & 105.2 \\
\hline 49 & $\begin{array}{c}\text { Computer and electronic } \\
\text { products } \ldots \ldots \ldots .\end{array}$ & 334 & 8.1 & 183.4 & 196.2 & 198.1 & 198.5 & 202.2 & 206.2 & 208.9 & 209.5 & 209.7 & 208.9 & 206.9 & 203.6 & 201.5 & 199.1 \\
\hline 50 & $\begin{array}{c}\text { Electrical equipment, } \\
\text { appliances, and }\end{array}$ & & & & & & & & & & & & 200.9 & & & 1000 & 199.1 \\
\hline 51 & $\begin{array}{l}\text { components } \ldots \ldots . \\
\text { Motor vehicles and parts . }\end{array}$ & $\begin{array}{r}335 \\
3361-3\end{array}$ & $\begin{array}{l}2.2 \\
7.4\end{array}$ & $\begin{array}{r}104.9 \\
97.2\end{array}$ & $\begin{array}{r}105.0 \\
0.8\end{array}$ & 106.1 & 106.1 & 104.4 & $\begin{array}{r}106.0 \\
886\end{array}$ & 105.7 & 106.6 & 106.7 & 106.4 & 105.5 & 101.8 & 102.0 & 99.8 \\
\hline 52 & $\begin{array}{l}\text { Aerospace and } \\
\text { miscellaneous } \\
\text { transportation }\end{array}$ & $3001-3$ & 7.4 & 97.2 & 95.8 & 95.5 & 93.9 & 93.0 & 88.6 & 83.1 & 83.4 & 86.9 & 89.2 & 79.4 & 80.4 & 77.5 & 75.3 \\
\hline 53 & $\begin{array}{l}\text { equipment ...... } \\
\text { Furniture and related }\end{array}$ & $3364-9$ & 3.5 & 122.3 & 126.9 & 126.4 & 127.4 & 125.2 & 125.1 & 124.4 & 124.0 & 125.6 & 124.0 & 123.3 & 102.1 & 98.9 & 111.6 \\
\hline & products ..... & 337 & 1.8 & 102.0 & 101.4 & 100.1 & 98.1 & 96.4 & 95.9 & 94.6 & 94.4 & 93.7 & 92.8 & 89.2 & 87.6 & 84.8 & 82.3 \\
\hline 54 & Miscellaneous .... & 339 & 3.3 & 115.9 & 116.0 & 117.2 & 117.8 & 115.3 & 117.1 & 116.3 & 116.6 & 116.1 & 116.6 & 118.8 & 116.7 & 116.0 & 114.1 \\
\hline $\begin{array}{l}55 \\
56\end{array}$ & $\begin{array}{l}\text { Nondurable manufacturing } \\
\text { Food, beverage, and }\end{array}$ & $\ldots$ & 35.3 & 106.6 & 106.6 & 106.8 & 106.8 & 106.0 & 106.2 & 106.0 & 106.2 & 105.5 & 105.2 & 104.5 & 99.3 & 102.8 & 101.2 \\
\hline & tobacco products & 311,2 & 11.3 & 110.1 & 110.0 & 110.1 & 110.0 & 109.7 & 111.0 & 110.6 & 110.4 & 109.9 & 109.3 & 109.0 & 108.7 & 109.7 & 109.7 \\
\hline 57 & Tex tile and product mills & 313,4 & 1.4 & 80.5 & 77.1 & 77.2 & 75.3 & 75.2 & 74.7 & 73.3 & 73.4 & 72.4 & 72.5 & 73.2 & 71.2 & 70.7 & 68.4 \\
\hline 58 & Apparel and leather .... & 315,6 & 1.0 & 78.5 & 76.8 & 78.7 & 77.8 & 77.1 & 76.0 & 75.6 & 74.5 & 75.9 & 76.6 & 77.1 & 76.1 & 73.9 & 73.7 \\
\hline 59 & Paper .......... & 322 & 3.1 & 95.8 & 95.4 & 97.3 & 96.0 & 93.7 & 95.1 & 93.8 & 96.4 & 94.6 & 93.8 & 94.5 & 91.3 & 89.5 & 87.7 \\
\hline 60 & Printing and support . & 323 & 2.4 & 99.8 & 99.4 & 99.0 & 98.4 & 97.3 & 98.4 & 97.4 & 97.0 & 94.2 & 92.6 & 94.0 & 93.2 & 93.2 & 92.3 \\
\hline 61 & $\begin{array}{l}\text { Petroleum and coal } \\
\text { products } . . . .\end{array}$ & 324 & 1.8 & 1087 & 108.1 & 1085 & 1117 & 1106 & 1095 & 110.6 & 1109 & 110.0 & 1103 & 1086 & 968 & 1072 & 1071 \\
\hline 62 & Chemical .......... & 325 & 10.7 & 114.2 & 114.7 & 114.6 & 114.6 & 113.6 & 113.2 & 113.2 & 113.4 & 112.7 & 112.3 & 111.2 & 102.1 & 108.6 & 104.7 \\
\hline 63 & $\begin{array}{l}\text { Plastics and rubber } \\
\text { products } \ldots . . .\end{array}$ & 326 & 3.8 & 103.4 & 105.4 & 104.5 & 103.0 & 102.8 & 102.0 & 101.3 & 101.5 & 102.4 & 102.7 & 100.9 & 99.0 & 96.7 & 93.8 \\
\hline 64 & $\begin{array}{l}\text { Other manufacturing } \\
\text { (non-NAICS) } .\end{array}$ & 1133,5111 & 4.7 & 92.9 & 91.7 & 91.9 & 91.3 & 91.2 & 91.0 & 89.1 & 88.5 & 88.4 & 87.2 & 86.6 & 86.2 & 86.5 & 86.0 \\
\hline 65 & Mining & 21 & 7.2 & 101.4 & 102.9 & 103.9 & 103.2 & 103.6 & 103.9 & 104.0 & 104.1 & 104.2 & 105.7 & 105.1 & 95.1 & 102.0 & 104.6 \\
\hline 66 & Utilities. & 2211,2 & 9.6 & 108.2 & 109.1 & 108.2 & 110.8 & 112.6 & 108.7 & 110.4 & 108.0 & 110.0 & 108.9 & 103.9 & 106.4 & 107.1 & 108.8 \\
\hline 67 & Electric & 2211 & 8.2 & 110.4 & 111.1 & 109.7 & 112.4 & 113.5 & 110.4 & 111.8 & 109.2 & 112.3 & 111.3 & 105.7 & 108.7 & 109.3 & 111.0 \\
\hline 68 & Natural gas. & 2212 & 1.4 & 98.2 & 99.4 & 101.2 & 103.2 & 107.9 & 101.0 & 103.4 & 102.0 & 99.4 & 98.1 & 95.4 & 95.8 & 97.2 & 98.8 \\
\hline 69 & $\begin{array}{l}\text { Manufacturing excluding } \\
\text { computers, communications } \\
\text { equipment, and }\end{array}$ & & & & & & & & & & & & & & & & \\
\hline 70 & $\begin{array}{l}\text { semiconductors } \ldots \ldots \ldots \ldots \\
\text { Manufacturing excluding motor }\end{array}$ & $\ldots$ & 77.8 & 107.6 & 107.7 & 107.6 & 107.6 & 106.8 & 106.7 & 105.6 & 105.6 & 105.4 & 105.3 & 104.2 & 99.9 & 100.7 & 99.2 \\
\hline & vehicles and parts ........ & & 75.7 & 114.3 & 115.3 & 115.4 & 115.5 & 114.8 & 115.3 & 114.7 & 114.7 & 114.2 & 113.8 & 113.4 & 108.5 & 109.5 & 108.0 \\
\hline
\end{tabular}

NoTE: The statistics in this release cover output, capacity, and capacity utilization in the industrial sector, which is defined by the Federal Reserve to comprise manufacturing, mining, industral sector, which is defined by the Federal Reserve to comprise manufacturing, mining, A e cor AAICS AICS sects 2211 and 2212. Manufactuing comprises NAICS industries (sector 31-33) lus the logging indusy ablishing information respectively), but historically they were considered to be manufacturing and were included in the industrial sector under the Standard Industrial Classification (SIC) system. In Dystem to NAICS.

1. Data in this table appear in the Board's G.17(419) monthly statistical release The data re also available on the Board's website, www.federalreserve gov/releases/g17. The latest historical revision of the industrial production index and the capacity utilization rates was released on March 28, 2008. The 2008 annual revision is described in an article in the Federal Reserve Bulletin titled "Industrial Production and Capacity Utilization: The 2008 Revision," www.federalreserve.gov/pubs/bulletin/2008/pdf/Industrial08.pdf.

2. North American Industry Classification System. 
3.10 U.S. INTERNATIONAL TRANSACTIONS Summary

Millions of dollars; quarterly data seasonally adjusted except as noted

\begin{tabular}{|c|c|c|c|c|c|c|c|c|c|}
\hline \multirow{2}{*}{\multicolumn{2}{|c|}{ Item credits or debits }} & \multirow{2}{*}{2005} & \multirow{2}{*}{2006} & \multirow{2}{*}{2007} & \multicolumn{2}{|c|}{2007} & \multicolumn{3}{|c|}{2008} \\
\hline & & & & & Q3 & Q4 & Q1 & $\mathrm{Q}^{\mathrm{r}}$ & Q3 \\
\hline 1 & Balance on current account & $-728,993$ & $-788,116$ & $-731,214$ & $-172,952$ & $-167,241$ & $-175,640$ & $-180,944$ & $-174,091$ \\
\hline & Balance on goods and services & $-711,567$ & $-753,283$ & $-700,258$ & $-168,114$ & $-173,783$ & $-177,110$ & $-180,079$ & $-176,536$ \\
\hline 3 & Exports ............... & $1,283,753$ & $1,457,015$ & $1,645,726$ & 424,873 & 435,465 & 451,645 & 475,498 & 489,053 \\
\hline 4 & Imports & $-1,995,320$ & $-2,210,298$ & $-2,345,984$ & $-592,986$ & $-609,248$ & $-628,756$ & $-655,578$ & $-665,589$ \\
\hline 5 & Income, net & 72,358 & 57,194 & 81,749 & 22,958 & 36,327 & 33,212 & 28,164 & 30,835 \\
\hline 6 & Investment, net & 78,758 & 63,804 & 88,776 & 24,729 & 38,151 & 35,009 & 29,945 & 32,636 \\
\hline 7 & Direct ...... & 173,205 & 184,146 & 233,861 & 59,710 & 74,835 & 70,261 & 64,868 & 65,299 \\
\hline 8 & Portfolio. & $-94,447$ & $-120,342$ & $-145,085$ & $-34,981$ & $-36,684$ & $-35,252$ & $-34,923$ & $-32,663$ \\
\hline 9 & Compensation of employees & $-6,400$ & $-6,609$ & $-7,027$ & $-1,771$ & $-1,824$ & $-1,797$ & $-1,780$ & $-1,800$ \\
\hline 10 & Unilateral current transfers, net & $-89,784$ & $-92,027$ & $-112,705$ & $-27,796$ & $-29,784$ & $-31,742$ & $-29,028$ & $-28,390$ \\
\hline & Change in U.S. government assets other than official & & & & & & & & \\
\hline & reserve assets, net (increase, - ) $\ldots \ldots \ldots \ldots \ldots \ldots \ldots$ & 5,539 & 5,346 & $-22,273$ & 623 & $-22,744$ & 3,265 & $-41,592$ & $-225,994$ \\
\hline 12 & Change in U.S. official reserve assets (increase, - ) & 14,096 & 2,374 & -122 & -54 & -22 & -276 & $-1,267$ & -179 \\
\hline 13 & Gold $\ldots \ldots \ldots \ldots \ldots \ldots$ & & & & 0 & 0 & & & 0 \\
\hline 14 & Special drawing rights (SDRs) & 4,511 & -223 & -154 & -37 & -35 & -29 & -22 & -30 \\
\hline 15 & Reserve position in International Monetary Fund & 10,200 & 3,331 & 1,021 & 230 & 285 & 112 & -955 & 256 \\
\hline 16 & Foreign currencies $\ldots \ldots \ldots \ldots \ldots \ldots \ldots \ldots$ & -615 & -734 & -989 & -247 & -272 & -359 & -290 & -405 \\
\hline \multirow{5}{*}{$\begin{array}{l}17 \\
18 \\
19 \\
20 \\
21\end{array}$} & Change in U.S. private assets abroad (increase, - ) & $-566,266$ & $-1,259,469$ & $-1,267,459$ & $-171,045$ & $-130,990$ & $-263,634$ & 145,558 & 235,678 \\
\hline & Bank-reported claims ${ }^{2}$. & $-207,625$ & $-488,424$ & $-644,751$ & $-88,697$ & $-115,926$ & $-221,316$ & 213,859 & 151,994 \\
\hline & Nonbank-reported claims . & $-71,207$ & $-164,597$ & -706 & 80,012 & 100,043 & 81,848 & 49,324 & 53,787 \\
\hline & U.S. purchase of foreign securities, net & $-251,199$ & $-365,204$ & $-288,731$ & $-100,317$ & $-4,202$ & $-35,066$ & $-33,576$ & 86,768 \\
\hline & U.S. direct investments abroad, net . & $-36,235$ & $-241,244$ & $-333,271$ & $-62,043$ & $-110,905$ & $-89,100$ & $-84,049$ & $-56,871$ \\
\hline \multirow{6}{*}{$\begin{array}{l}22 \\
23 \\
24 \\
25 \\
26 \\
27\end{array}$} & Change in foreign official assets in United States (increase, + ). & 259,268 & 487,939 & 411,058 & 13,469 & 145,497 & 173,533 & 145,391 & 117,663 \\
\hline & U.S. Treasury securities. & 112,841 & 208,564 & 58,865 & $-25,810$ & 42,728 & 88,649 & 58,143 & 116,479 \\
\hline & Other U.S. government obligations & 100,493 & 219,837 & 171,465 & 18,022 & 12,109 & 79,234 & 93,145 & $-8,361$ \\
\hline & Other U.S. government liabilities ${ }^{2}$. & -421 & 2,816 & 5,342 & 913 & 4,132 & 1,645 & 2,439 & 1,714 \\
\hline & Other U.S. liabilities reported by U.S. banks ${ }^{2}$. & 26,260 & 22,365 & 108,695 & 9,873 & 52,537 & $-26,930$ & $-30,055$ & 9,617 \\
\hline & Other foreign official assets ${ }^{3} \ldots \ldots \ldots \ldots \ldots \ldots \ldots$ & 20,095 & 34,357 & 66,691 & 10,471 & 33,991 & 30,935 & 21,719 & $-1,786$ \\
\hline \multirow{7}{*}{$\begin{array}{l}28 \\
29 \\
30 \\
31 \\
32 \\
33 \\
34\end{array}$} & Change in foreign private assets in United States (increase, + ) & 988,079 & $1,573,174$ & $1,646,645$ & 253,007 & 234,905 & 285,484 & $-122,672$ & 8,029 \\
\hline & U.S. bank-reported liabilities ${ }^{4}$ & 214,736 & 461,100 & 532,813 & 53,925 & 123,987 & 79,088 & $-256,616$ & $-147,874$ \\
\hline & U.S. nonbank-reported liabilities & 69,572 & 242,727 & 156,290 & 55,599 & $-111,846$ & 84,085 & $-54,350$ & 83,598 \\
\hline & Foreign private purchases of U.S. Treasury securities, net & 132,300 & $-58,204$ & 156,825 & 67,406 & 60,059 & 63,263 & 65,692 & 89,506 \\
\hline & U.S. currency flows $\ldots \ldots \ldots \ldots \ldots \ldots \ldots \ldots \ldots$ & 8,447 & 2,227 & $-10,675$ & 655 & $-3,530$ & -914 & 230 & 5,845 \\
\hline & Foreign purchases of other U.S. securities, net . & 450,386 & 683,363 & 573,850 & $-30,486$ & 110,489 & $-20,475$ & 17,068 & $-89,163$ \\
\hline & Foreign direct investments in United States, net . & 112,638 & 241,961 & 237,542 & 105,908 & 55,746 & 80,437 & 105,304 & 66,117 \\
\hline \multirow{4}{*}{$\begin{array}{l}35 \\
36 \\
37 \\
38\end{array}$} & Capital account transactions, net ${ }^{5}$ & $-4,036$ & $-3,880$ & $-1,843$ & -617 & -571 & -600 & -631 & -593 \\
\hline & Discrepancy ........... & 32,313 & $-47,078$ & $-41,287$ & 71,627 & $-45,600$ & $-14,131$ & 58,677 & 39,487 \\
\hline & Due to seasonal adjustment ... & & & & $-21,805$ & 8,892 & 9,271 & $-3,368$ & $-33,739$ \\
\hline & Before seasonal adjustment $\ldots \ldots \ldots \ldots \ldots$ & 32,313 & $-47,078$ & $-41,287$ & 93,431 & $-54,491$ & $-23,403$ & 62,045 & 73,226 \\
\hline \multirow{4}{*}{$\begin{array}{l}39 \\
40\end{array}$} & MEMo & & & & & & & & \\
\hline & Changes in official assets & & & & & & & & \\
\hline & U.S. official reserve assets (increase, - ). & 14,096 & 2,374 & -122 & -54 & -22 & -276 & $-1,267$ & -179 \\
\hline & $\begin{array}{l}\text { Foreign official assets in United States, ex cluding line } 25 \\
\quad(\text { increase },+)\end{array}$ & 259,689 & 485,123 & 405,716 & 12,556 & 141,365 & 171,888 & 142,952 & 115,949 \\
\hline & $\begin{array}{l}\text { Change in Organization of Petroleum Exporting Countries official } \\
\text { assets in United States (part of line 22) } \ldots \ldots \ldots \ldots \ldots \ldots \ldots\end{array}$ & & & & & & & & \\
\hline
\end{tabular}

1. Seasonal factors are not calculated for lines $11-16,18-20,22-35$ and 38-41.

2. Associated primarily with military sales contracts and other transactions arranged with or through foreign official agencies.

3. Consists of investments in U.S. corporate stocks and in debt securities of private corporations and state and local governments.

4 . Reporting banks included all types of depository institutions as well as some brokers and dealers.

\subsection{U.S. RESERVE ASSETS}

Millions of dollars, end of period

\begin{tabular}{|c|c|c|c|c|c|c|c|c|c|c|c|}
\hline \multirow{2}{*}{ Asset } & \multirow{2}{*}{2005} & \multirow{2}{*}{2006} & \multirow{2}{*}{2007} & \multicolumn{8}{|c|}{2008} \\
\hline & & & & Apr. & May & June & July & Aug. & Sept. & Oct. & Nov. ${ }^{p}$ \\
\hline 1 Total & 65,127 & 65,895 & 70,565 & 74,372 & 75,170 & 75,740 & 74,832 & 72,560 & 71,834 & 69,763 & 73,378 \\
\hline $\begin{array}{l}2 \text { Gold stock }^{1} \ldots \ldots \ldots \ldots \ldots \ldots \ldots \ldots \ldots \ldots \ldots \ldots \ldots \ldots \ldots \ldots \ldots \\
3 \text { Special drawing rights }{ }^{2,3} \ldots \ldots \ldots \ldots \ldots \\
4 \text { Reserve position in International Monetary }\end{array}$ & $\begin{array}{r}11,043 \\
8,210\end{array}$ & $\begin{array}{r}11,041 \\
8,870\end{array}$ & $\begin{array}{r}11,041 \\
9,476\end{array}$ & $\begin{array}{r}11,041 \\
9,767\end{array}$ & $\begin{array}{r}11,041 \\
9,771\end{array}$ & $\begin{array}{r}11,041 \\
9,849\end{array}$ & $\begin{array}{r}11,041 \\
9,772\end{array}$ & $\begin{array}{r}11,041 \\
9,494\end{array}$ & $\begin{array}{r}11,041 \\
9,418\end{array}$ & $\begin{array}{r}11,041 \\
9,001\end{array}$ & $\begin{array}{r}11,041 \\
9,023\end{array}$ \\
\hline 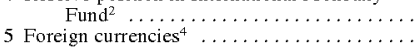 & $\begin{array}{r}8,036 \\
37,838\end{array}$ & $\begin{array}{r}5,040 \\
40,943\end{array}$ & $\begin{array}{r}4,244 \\
45,804\end{array}$ & $\begin{array}{r}4,253 \\
49,311\end{array}$ & $\begin{array}{r}5,111 \\
49,247\end{array}$ & $\begin{array}{r}5,237 \\
49,613\end{array}$ & $\begin{array}{r}4,930 \\
49,089\end{array}$ & $\begin{array}{r}4,774 \\
47,252\end{array}$ & $\begin{array}{r}4,750 \\
46,626\end{array}$ & $\begin{array}{r}4,433 \\
45,288\end{array}$ & $\begin{array}{r}7,344 \\
45,970\end{array}$ \\
\hline
\end{tabular}

NotE: The data presented in this table are available in the monthly statistical release "U.S. Reserve Assets; Foreign Official Assets Held at Federal Reserve Banks," on the Board's website at www federalreserve.gov/releases.

1. Gold held "under earmark" at Federal Reserve Banks for foreign and international accounts is not included in the gold stock of the United States; see table 3.13, line 3. Gold stock is valued at $\$ 42.22$ per fine troy ounce.

2. Special drawing rights (SDRs) are valued according to a technique adopted by the International Monetary Fund (IMF) in July 1974. Values are based on a weighted average of exchange rates for the currencies of member countries. From July 1974 through December 1980 sixteen currencies were used; since January 1981 , five currencies have been $u s e d$. U. SDR holdings and reserve positions in the IMF have also been valued on this basis since July 1974.
5. Consists of capital transfers (such as those of accompanying migrants entering or leaving the country and debt forgiveness) and the acquisition and disposal of nonproduced financial assets.

SouRCE: U.S. Department of Commerce, Bureau of Economic Analysis, Survey of Current Business. 
3.13 FOREIGN OFFICIAL ASSETS HELD AT FEDERAL RESERVE BANKS ${ }^{\prime}$

Millions of dollars, end of period

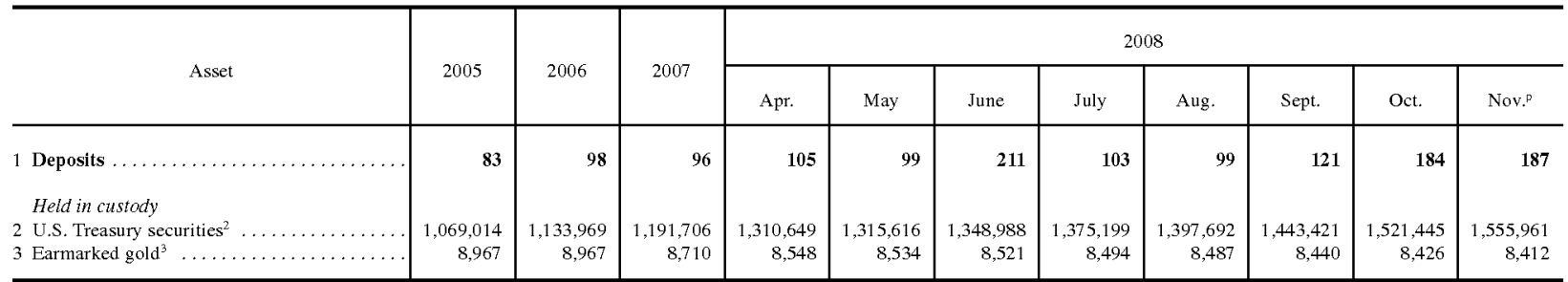

NoTE: The data presented in this table are available in the monthly statistical release "U.S. Reserve Assets; Foreign Official Assets Held at Federal Reserve Banks," on the Board's website at www federalreserve gov/releases.

1. Excludes deposits and U.S. Treasury securities held for international and regional organizations.

\subsection{SELECTED U.S. LIABILITIES TO FOREIGN OFFICIAL INSTITUTIONS}

Millions of dollars, end of period

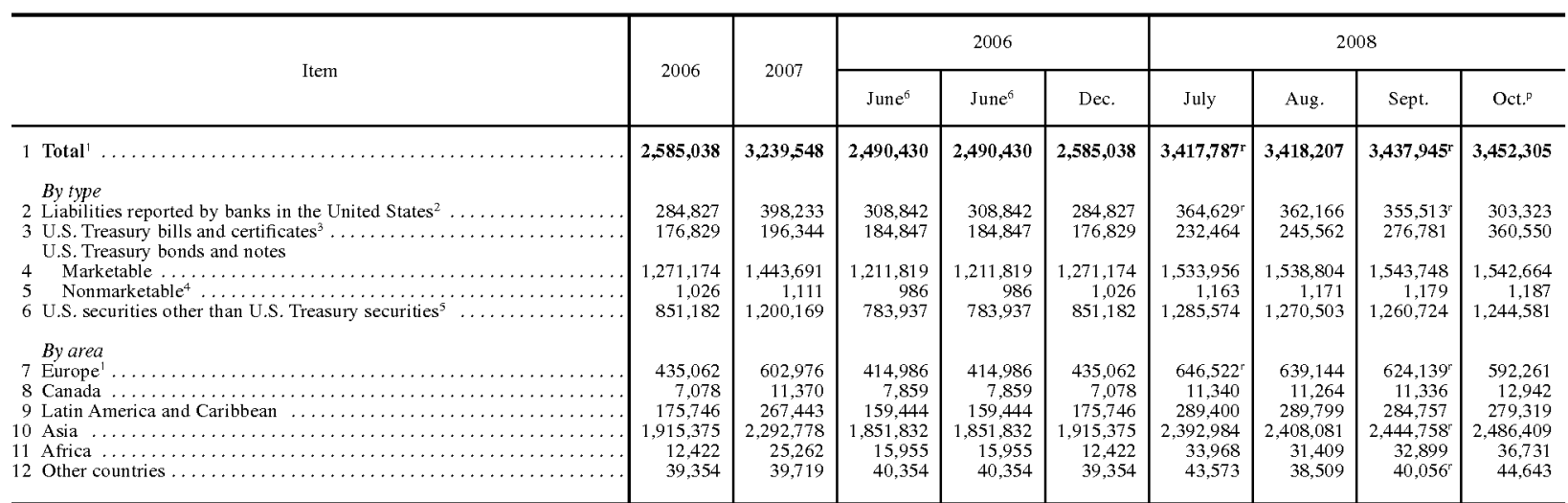

For data before June 2006, includes the Bank for International Settlements.

2. Principally demand deposits, time deposits, bankers acceptances, commercial paper,

negotiable time certificates of deposit, and borrowings under repurchase agreements.

3. Includes nonmarketable certificates of indebtedness and Treasury bills issued to official institutions of foreign countries.

4. Excludes notes issued to foreign official nonreserve agencies. Includes current value of zero-coupon Treasury bond issues to foreign governments as follows: Mexico, beginning March 1990, 30-year maturity issue; Venezuela, beginning December 1990, 30-year maturity issue; Argentina, beginning April 1993, 30-year maturity issue.

5. Debt securities of U.S. government corporations and federally sponsored agencies, and

2. Marketable U.S. Treasury bills, notes, and bonds and nonmarketable U.S. Treasury

securities, in each case measured at face (not market) value.
3. Held in foreign and international accounts and valued at $\$ 42.22$ per fine troy ounce; not included in the gold stock of the United States.

U.S. corporate stocks and bonds.

3.16 LIABILITIES TO, AND CLAIMS ON, FOREIGNERS Reported by Banks in the United States ${ }^{1}$ Payable in Foreign Currencies

Millions of dollars, end of period

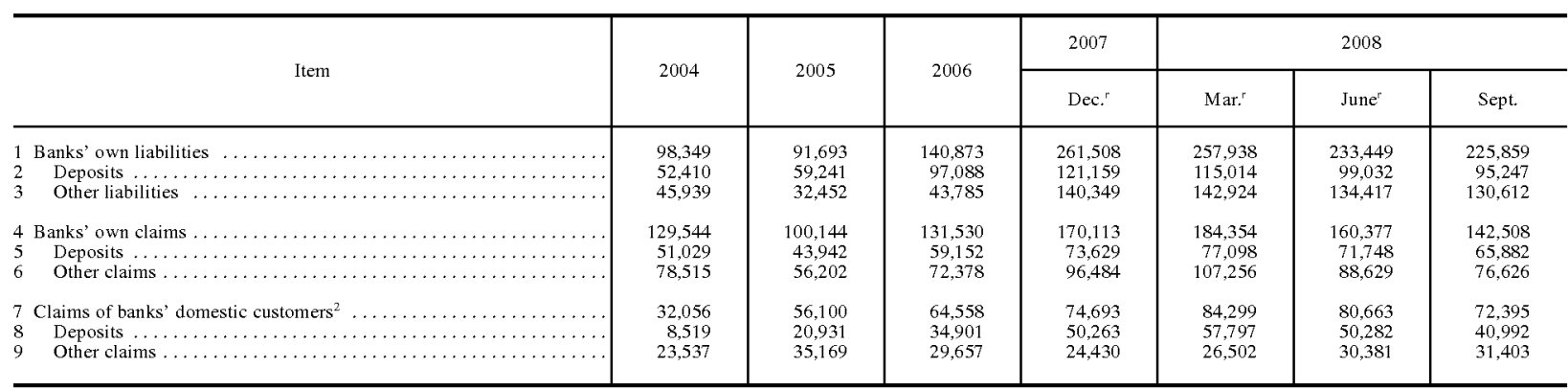

1. Data on claims exclude foreign currencies held by U.S. monetary authorities. foreigners' holdings of selected U.S. long-term securities. Figures in the first column are comparable to those for earlier dates; figures in the second column are based in part on a benchmark survey as of end-June 2006 and are comparable to those shown for the following

SOURCE: Based on U.S. Department of the Treasury data and on data reported to the Treasury by banks (including Federal Reserve Banks) and securities dealers in the United States, and in periodic benchmark surveys of foreign portfolio investment in the United States.

2. Assets owned by customers of the reporting bank located in the United States that represent claims on foreigners held by reporting banks for the accounts of the domestic customers. 
3.17 LIABILITIES TO FOREIGNERS Reported by Banks in the United States ${ }^{1}$ Payable in U.S. dollars

Millions of dollars, end of period

\begin{tabular}{|c|c|c|c|c|c|c|c|c|c|c|c|}
\hline \multirow{2}{*}{\multicolumn{2}{|c|}{ Item }} & \multirow{2}{*}{2005} & \multirow{2}{*}{2006} & \multirow{2}{*}{2007} & \multicolumn{7}{|c|}{2008} \\
\hline & & & & & Apr. & May & June & July & Aug. & Sept. ${ }^{r}$ & Oct. $^{p}$ \\
\hline \multicolumn{12}{|c|}{ By Holder and Type of LIabILITy } \\
\hline 1 & Total, all foreigners & $3,080,907$ & $3,851,558$ & $4,426,986$ & $4,455,418$ & $4,397,986$ & $4,245,262$ & $4,235,339$ & $4,263,327^{\mathrm{r}}$ & $4,248,314$ & $4,456,710$ \\
\hline & $\begin{array}{l}\text { Banks' own liabilities } \\
\text { By type of liability }\end{array}$ & $2,299,950$ & $2,924,438$ & $3,301,255$ & $3,264,288$ & $3,197,513$ & $3,075,427$ & $3,049,733$ & $3,055,511^{r}$ & $3,027,478$ & $3,143,522$ \\
\hline 3 & Deposits ${ }^{2} \ldots$ & $1,043,801$ & $1,315,290$ & $1,541,223$ & $1,507,001$ & $1,447,363$ & $1,464,931$ & $1,428,346$ & $1,370,019^{r}$ & $1,458,368$ & $1,641,428$ \\
\hline 4 & Other ... & $1,256,149$ & $1,609,148$ & $1,760,032$ & $1,757,287$ & $1,750,150$ & $1,610,496$ & $1,621,387$ & $1,685,492$ & $1,569,110$ & $1,502,094$ \\
\hline 5 & Of which: repurchase agreements ${ }^{3}$ & 713,327 & $1,028,974$ & $1,107,751$ & $1,092,243$ & $1,088,385$ & 987,456 & 995,842 & $1,026,746^{r}$ & 895,475 & 752,539 \\
\hline 6 & $\begin{array}{c}\text { Banks' custody liabilities }{ }^{4} \ldots \ldots \ldots \ldots \\
\text { By type of liability }\end{array}$ & 780,957 & 927,120 & $1,125,731$ & $1,191,130$ & $1,200,473$ & $1,169,835$ & $1,185,606$ & $1,207,816^{r}$ & $1,220,836$ & $1,313,188$ \\
\hline 7 & U.S. Treasury bills and certificates ${ }^{5}$ & 259,843 & 250,886 & 300,130 & 357,172 & 368,610 & 375,094 & 379,321 & $410,908^{r}$ & 501,815 & 649,175 \\
\hline 8 & $\begin{array}{c}\text { Other negotiable and readily transferable } \\
\text { instruments }{ }^{6} \ldots \ldots \ldots \ldots \ldots \ldots \ldots\end{array}$ & 319,598 & 371,732 & 504,923 & 517,824 & 513,050 & 477,412 & 489,478 & 486,532 & 432,149 & 376,384 \\
\hline 9 & $\begin{array}{l}\text { Of which: negotiable time } \\
\text { certificates of deposit held in custody }\end{array}$ & & & & & & & & & & \\
\hline & for foreigners $\ldots \ldots \ldots \ldots \ldots \ldots$ & 53,594 & 66,155 & 97,990 & 126,418 & 133,182 & 89,021 & 107,231 & $115,149^{r}$ & 100,729 & 90,717 \\
\hline 10 & Of which: short-term agency securities ${ }^{7}$ & 136,783 & 113,865 & 200,312 & 180,566 & 165,199 & 168,155 & 163,923 & 154,520 & 156,136 & 131,585 \\
\hline 11 & 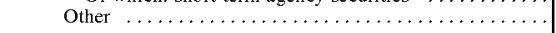 & 201,516 & 304,502 & 320,678 & 316,134 & 318,813 & 317,329 & 316,807 & 310,376 & 286,872 & 287,629 \\
\hline 12 & International and regional organizations ${ }^{B}$ & 20,793 & 29,425 & 27,164 & 24,776 & 28,075 & 24,398 & $26,158^{r}$ & 27,681 & 23,672 & 24,183 \\
\hline 13 & Banks' own liabilities..$\ldots \ldots \ldots \ldots$ & 15,612 & 25,770 & 22,929 & 19,105 & 20,316 & 18,456 & $19,726^{\mathrm{r}}$ & 21,465 & 17,809 & 10,122 \\
\hline 14 & Deposits $^{2} \ldots \ldots \ldots \ldots$ & 8,361 & 19,021 & 17,784 & 14,599 & 13,997 & 13,397 & 16,161 & 15,892 & 12,346 & 6,538 \\
\hline 15 & Other $\ldots$. & 7,251 & 6,749 & 5,145 & 4,506 & 6,319 & 5,059 & $3,565^{r}$ & 5,573 & 5,463 & 3,584 \\
\hline 16 & Banks' custody liabilities ${ }^{4}$ & 5,181 & 3,655 & 4,235 & 5,671 & 7,759 & 5,942 & 6,432 & 6,216 & 5,863 & 14,061 \\
\hline 17 & U.S. Treasury bills and certificates & 1,085 & 800 & 250 & 416 & 2,447 & 1,073 & 547 & 435 & 286 & 7,929 \\
\hline 18 & $\begin{array}{l}\text { Other negotiable and readily transferable } \\
\text { instruments }^{6} \ldots \ldots \ldots \ldots \ldots \ldots \ldots\end{array}$ & 4,096 & 2,855 & 3,985 & 5,255 & 5,312 & 4,869 & 5,885 & 5,781 & 5,577 & 6,132 \\
\hline 19 & Official institutions ${ }^{9}$ & 498,510 & 461,656 & 594,577 & 567,009 & 568,467 & 570,865 & $597,093^{r}$ & 607,728 & 632,294 & 663,873 \\
\hline 20 & Banks' own liabilities & 170,984 & 178,954 & 216,221 & 188,201 & 197,722 & 191,501 & $205,475^{r}$ & 211,126 & 212,823 & 198,526 \\
\hline 21 & Deposits ${ }^{2} \ldots \ldots \ldots$ & 45,426 & 51,380 & 49,204 & 47,003 & 46,554 & 44,817 & 51,079 & 50,701 & 53,973 & 54,820 \\
\hline 22 & Other $\ldots \ldots \ldots \ldots \ldots \ldots \ldots \ldots \ldots$ & 125,558 & 127,574 & 167,017 & 141,198 & 151,168 & 146,684 & $154,396^{r}$ & 160,425 & 158,850 & 143,706 \\
\hline 23 & Banks' custody liabilities ${ }^{4}$ & 327,526 & 282,702 & 378,356 & 378,808 & 370,745 & 379,364 & 391,618 & 396,602 & 419,471 & 465,347 \\
\hline 24 & U.S. Treasury bills and certificates ${ }^{5}$ & 201,863 & 176,829 & 196,344 & 215,711 & 219,976 & 226,625 & 232,464 & 245,562 & 276,781 & 360,550 \\
\hline 25 & $\begin{array}{l}\text { Other negotiable and readily transferable } \\
\text { instruments }{ }^{6} \ldots \ldots \ldots \ldots \ldots \ldots \ldots\end{array}$ & 125,663 & 105,873 & 182,012 & 163,097 & 150,769 & 152,739 & 159,154 & 151,040 & 142,690 & 104,797 \\
\hline 26 & Banks $^{10}$ & $1,792,040$ & $2,258,115$ & $2,491,653$ & $2,426,372$ & $2,337,293$ & $2,277,159$ & $2,228,856$ & $2,232,359^{r}$ & 2,31 & $2,568,881$ \\
\hline 27 & Banks' own liabilities & $1,566,967$ & $1,917,300$ & $2,149,292$ & $2,063,664$ & $1,969,420$ & $1,939,306$ & $1,893,671$ & $1,897,551$ & $1,979,667$ & $2,226,189$ \\
\hline 28 & Deposits ${ }^{2} \ldots \ldots \ldots$ & 841,248 & $1,025,334$ & $1,174,296$ & $1,127,346$ & $1,068,700$ & $1,073,172$ & $1,023,076$ & 971,224 & $1,036,052$ & $1,241,327$ \\
\hline 29 & Other $\ldots$ & 725,719 & 891,966 & 974,996 & 936,318 & 900,720 & 866,134 & 870,595 & $926,327^{r}$ & 943,615 & 984,862 \\
\hline 30 & Banks' custody liabilities ${ }^{4}$ & 225,073 & 340,815 & 342,361 & 362,708 & 367,873 & 337,853 & 335,185 & $334,808^{r}$ & 334,621 & 342,692 \\
\hline 31 & U.S. Treasury bills and certificates ${ }^{5}$ & 23,771 & 31,153 & 38,383 & 49,461 & 43,778 & 44,589 & 44,756 & $49,430^{r}$ & 50,151 & 66,714 \\
\hline 32 & Other negotiable and readily & & & & & & & & & & \\
\hline & transferable instruments ${ }^{6}$ & 48,776 & 66,378 & 64,309 & 85,471 & 90,848 & 63,914 & 62,299 & $62,897^{r}$ & 65,340 & 57,859 \\
\hline 33 & Other $\ldots \ldots \ldots \ldots \ldots \ldots$. & 152,526 & 243,284 & 239,669 & 227,776 & 233,247 & 229,350 & 228,130 & 222,481 & 219,130 & 218,119 \\
\hline 34 & Other foreigners $^{11}$ & 769,564 & $1,102,362$ & $1,313,592$ & $1,437,261$ & $1,464,151$ & $1,372,840$ & $1,383,232$ & $1,395,559^{r}$ & $1,278,060$ & $1,199,773$ \\
\hline 35 & Banks' own liabilities & 546,387 & 802,414 & 912,813 & 993,318 & $1,010,055$ & 926,164 & 930,861 & $925,369^{r}$ & 817,179 & 708,685 \\
\hline 36 & Deposits $^{2} \ldots \ldots \ldots \ldots$ & 148,766 & 219,555 & 299,939 & 318,053 & 318,112 & 333,545 & 338,030 & $332,202^{r}$ & 355,997 & 338,743 \\
\hline 37 & Other ... & 397,621 & 582,859 & 612,874 & 675,265 & 691,943 & 592,619 & 592,831 & $593,167^{r}$ & 461,182 & 369,942 \\
\hline 38 & Banks' custodial liabilities & 223,177 & 299,948 & 400,779 & 443,943 & 454,096 & 446,676 & 452,371 & $470,190^{r}$ & 460,881 & 491,088 \\
\hline 39 & U.S. Treasury bills and certificates & 33,124 & 42,104 & 65,153 & 91,584 & 102,409 & 102,807 & 101,554 & 115,481 & 174,597 & 213,982 \\
\hline 40 & Other negotiable and readily & & & & & & & & & & \\
\hline & transferable instruments ${ }^{6}$ & 142,188 & 196,728 & 255,618 & 265,654 & 266,611 & 259,058 & 265,351 & $268,322^{r}$ & 218,542 & 207,599 \\
\hline 41 & Other $\ldots \ldots \ldots \ldots \ldots \ldots \ldots \ldots \ldots \ldots \ldots \ldots \ldots \ldots \ldots$ & 47,865 & 61,116 & 80,008 & 86,705 & 85,076 & 84,811 & 85,466 & 86,387 & 67,742 & 69,507 \\
\hline & MEMo & & & & & & & & & & \\
\hline 42 & Own foreign offices ${ }^{12}$ & $1,552,323$ & $1,938,224$ & $2,020,906$ & $2,025,732$ & $1,944,612$ & $1,870,603$ & $1,836,023$ & $1,816,231^{r}$ & $1,910,656$ & $2,123,692$ \\
\hline & BY AREA OR COUNTRY & & & & & & & & & & \\
\hline 43 & Total, all foreigners & $3,080,907$ & $3,851,558$ & $4,426,986$ & $4,455,418$ & $4,397,986$ & $4,245,262$ & $4,235,339$ & $4,263,327^{r}$ & $4,248,314$ & $4,456,710$ \\
\hline 44 & Foreign countries & $3,060,114$ & $3,822,133$ & $4,399,822$ & $4,430,642$ & $4,369,911$ & $4,220,864$ & $4,209,181^{r}$ & $4,235,646^{r}$ & $4,224,642$ & $4,432,527$ \\
\hline 45 & Europe & $1,229,338$ & $1,482,788$ & $1,757,775$ & $1,780,836$ & $1,734,892$ & $1,612,272$ & $1,623,128^{r}$ & $1,648,072^{r}$ & $1,527,708$ & $1,492,176$ \\
\hline 46 & Austria & 3,604 & 3,841 & 4,988 & 4,310 & 4,409 & 5,388 & $3,893^{r}$ & 5,835 & 3,366 & 3,307 \\
\hline 47 & Belgium & 16,022 & 14,528 & 18,249 & 24,682 & 20,352 & 15,628 & $14,276^{r}$ & 12,767 & 13,895 & 12,963 \\
\hline 48 & Denmark. & 1,537 & 931 & 768 & 761 & 1,028 & 4,749 & 4,774 & 4,171 & 3,976 & 3,971 \\
\hline 49 & Finland. & 3,612 & 3,204 & 1,263 & 1,856 & 1,284 & 1,326 & $1,475^{r}$ & 1,334 & 1,551 & 1,482 \\
\hline 50 & France. & 71,486 & 69,078 & 64,697 & 80,926 & 70,396 & 66,476 & $62,551^{r}$ & 64,062 & 81,814 & 80,869 \\
\hline 51 & Germany . & 58,960 & 69,894 & 97,585 & 96,112 & 93,325 & 86,847 & $90,813^{r}$ & 88,697 & 95,566 & 89,877 \\
\hline 52 & Greece .. & 1,200 & 1,488 & 1,348 & 1,215 & 1,530 & 1,824 & $2,041^{r}$ & 1,345 & 1,030 & 2,104 \\
\hline 53 & Ireland & 68,660 & 84,085 & 113,306 & 160,903 & 166,359 & 162,424 & $162,339^{r}$ & $171,007^{r}$ & 147,128 & 150,098 \\
\hline 54 & Italy & 7,075 & 7,350 & 8,076 & 6,300 & 8,525 & 6,457 & $6,599^{r}$ & 8,394 & 9,644 & 9,080 \\
\hline 55 & Luxembourg & 61,065 & 73,099 & 106,918 & 112,177 & 107,775 & 103,955 & 101,251 & $104,849^{r}$ & 97,709 & 96,616 \\
\hline 56 & Netherlands & 14,502 & 25,309 & 24,857 & 34,725 & 42,638 & 35,769 & 39,464 & $39,380^{r}$ & 41,504 & 44,111 \\
\hline 57 & Norway .... & 27,921 & 42,383 & 48,261 & 30,358 & 29,512 & 30,778 & 33,939 & 36,313 & 23,821 & 21,323 \\
\hline 58 & $\ldots \ldots \ldots \ldots \ldots$ & 2,716 & 2,250 & 2,993 & 2,253 & 2,916 & 3,260 & $2,361^{r}$ & 2,090 & 2,202 & 1,944 \\
\hline 59 & Russia $\ldots \ldots \ldots \ldots \ldots \ldots \ldots \ldots \ldots \ldots$ & 101,335 & 62,711 & 104,709 & 91,502 & 88,322 & 92,667 & 91,490 & 87,063 & 79,154 & 77,254 \\
\hline 60 & Spain & 9,535 & 8,941 & 11,477 & 13,687 & 12,554 & 12,850 & $13,076^{r}$ & 13,276 & 15,010 & 18,846 \\
\hline 61 & (2) & 4,771 & 3,715 & 7,677 & 6,961 & 3,606 & 4,711 & 2,647 & 3,166 & 12,225 & 5,064 \\
\hline 62 & Switzerland & 140,140 & 54,622 & 51,914 & 43,105 & 40,548 & 37,438 & 35,968 & $38,376^{r}$ & 44,355 & 57,846 \\
\hline 63 & Turkey ... & 9,895 & 10,369 & 12,098 & 18,587 & 16,510 & 18,471 & 21,594 & 22,729 & 19,977 & 17,212 \\
\hline 64 & United Kingdom & 563,253 & 888,945 & $1,013,963$ & 979,306 & 956,957 & 859,751 & 863,338 & 876,103 & 778,189 & 745,684 \\
\hline 65 & Chamnel Islands and Isle of Man & 29,559 & 33,360 & 25,192 & 19,374 & 15,860 & 13,745 & 15,984 & $13,639^{r}$ & 13,298 & 14,297 \\
\hline 66 & Yugoslavia $^{13}$ & 119 & 295 & 532 & 412 & 530 & 334 & 303 & 293 & 144 & 161 \\
\hline 67 & Other Europe and other former U.S.S.R. ${ }^{14}$. & 32,371 & 22,389 & 36,904 & 51,326 & 49,958 & 47,424 & 52,952 & 53,185 & 42,150 & 38,068 \\
\hline
\end{tabular}


3.17 LIABILITIES TO FOREIGNERS Reported by Banks in the United States ${ }^{1}$ - Continued Payable in U.S. dollars

Millions of dollars, end of period

\begin{tabular}{|c|c|c|c|c|c|c|c|c|c|c|c|}
\hline & \multirow{2}{*}{ Item } & \multirow{2}{*}{2005} & \multirow{2}{*}{2006} & \multirow{2}{*}{2007} & \multicolumn{7}{|c|}{2008} \\
\hline & & & & & Apr. & May & June & July & Aug. & Sept ${ }^{r}$ & Oct. $^{p}$ \\
\hline & $\begin{array}{l}\text { MEMo } \\
\text { European Union }{ }^{15}\end{array}$ & n.a. & $1,267,657$ & $1,503,687$ & $1,562,714$ & $1,529,799$ & $1,403,581$ & $1,407,397\ulcorner$ & $1,431,504$ & $1,329,216$ & $1,283,018$ \\
\hline 69 & Canada & 33,552 & 44,613 & 59,391 & 70,047 & 73,165 & 75,690 & 70,679 & $66,884^{r}$ & 67,864 & 78,981 \\
\hline 70 & Latin America & 133,637 & 156,731 & 172,931 & 169,280 & 180,449 & 173,464 & 175,929 & $180,862^{r}$ & 176,363 & 193,908 \\
\hline 71 & Argentina & 9,674 & 10,506 & 11,974 & 12,641 & 12,176 & 11,558 & 11,594 & 11,574 & 13,305 & 12,991 \\
\hline & Brazil ... & 11,900 & 16,067 & 24,418 & 15,220 & 28,080 & 24,022 & 22,681 & $24,213 r$ & 17,994 & 20,723 \\
\hline 73 & Chile. & 8,961 & 16,839 & 15,539 & 16,158 & 13,380 & 13,953 & 13,558 & 13,572 & 14,474 & 16,643 \\
\hline 74 & Colombia & 6,477 & 11,657 & 10,971 & 10,472 & 11,001 & 11,011 & 10,997 & $11,389^{r}$ & 12,197 & 12,174 \\
\hline 75 & Ecuador & 3,393 & 3,409 & 3,273 & 3,702 & 3,797 & 3,431 & 3,437 & 3,375 & 3,695 & 3,752 \\
\hline 76 & Guatemala & 1,643 & 1,420 & 1,816 & 1,893 & 1,919 & 2,005 & 1,685 & 1,684 & 1,642 & 1,744 \\
\hline 77 & Mexico ... & 42,532 & 45,349 & 52,354 & 52,177 & 51,791 & 49,785 & 54,728 & $58,553^{r}$ & 56,128 & 65,580 \\
\hline 78 & 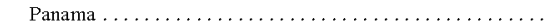 & 5,262 & 7,125 & 6,996 & 7,667 & 7,613 & 7,155 & 7,400 & $6,923^{r}$ & 7,624 & 8,059 \\
\hline 79 & $\ldots \ldots \ldots \ldots \ldots \ldots \ldots \ldots \ldots \ldots \ldots \ldots \ldots \ldots \ldots$ & 3,051 & 4,267 & 5,168 & 6,900 & 6,235 & 6,564 & 6,467 & 6,321 & 5,396 & 5,896 \\
\hline 80 & $\ldots \ldots \ldots \ldots \ldots \ldots \ldots$ & 4,939 & 6,116 & 6,367 & 6,188 & 6,362 & 5,748 & 5,665 & 5,481 & 5,583 & 5,911 \\
\hline 81 & $\ldots \ldots \ldots \ldots \ldots \ldots \ldots$ & 27,261 & 22,759 & 23,029 & 23,607 & 25,918 & 25,844 & 25,219 & 25,966 & 26,106 & 27,728 \\
\hline 82 & Other Latin America .. & 8,544 & 11,217 & 11,026 & 12,655 & 12,177 & 12,388 & 12,498 & 11,811 & 12,219 & 12,707 \\
\hline 83 & Caribbean & $1,214,058$ & $1,669,856$ & $1,838,464$ & $1,851,603$ & $1,817,175$ & $1,816,528$ & $1,773,526$ & $1,768,378$ & $1,806,228$ & $1,908,446$ \\
\hline 84 & Bahamas & 211,459 & 256,173 & 284,539 & 288,586 & 284,695 & 291,798 & 301,699 & $280,458^{r}$ & 300,869 & 288,828 \\
\hline 85 & Bermuda & 52,132 & 55,129 & 48,524 & 44,898 & 46,061 & 49,264 & 50,162 & 45,134 & 44,705 & 47,035 \\
\hline 86 & British Virgin Islands & n.a. & 21,493 & 33,579 & 41,082 & 39,140 & 38,805 & 39,892 & $41,247^{r}$ & 41,915 & 40,985 \\
\hline 87 & Cayman Islands .... & 907,840 & $1,297,459$ & $1,417,794$ & $1,434,281$ & $1,404,289$ & $1,395,234$ & $1,341,814$ & $1,361,148^{r}$ & $1,374,349$ & $1,485,028$ \\
\hline 88 & Cuba . & 120 & 82 & 80 & 92 & 94 & 93 & 92 & 94 & 94 & 93 \\
\hline 89 & Jamaica. & 916 & 1,023 & 1,323 & 1,100 & 1,092 & 1,458 & 1,413 & 1,312 & 1,153 & 1,011 \\
\hline 90 & Netherlands Antilles & 6,396 & 8,456 & 10,086 & 9,250 & 8,249 & 7,250 & 6,454 & 5,421 & 4,717 & 5,118 \\
\hline 91 & Trinidad and Tobago & 2,830 & 3,346 & 3,301 & 2,808 & 2,822 & 3,976 & 2,979 & 3,220 & 3,757 & 3,266 \\
\hline 92 & Other Caribbean ...... & 32,365 & 26,695 & 39,238 & 29,506 & 30,733 & 28,650 & 29,021 & 30,344 & 34,669 & 37,082 \\
\hline 93 & Asia & 408,192 & 422,744 & 527,061 & 494,703 & 495,419 & 480,912 & 500,045 & $526,972^{r}$ & 599,338 & 705,227 \\
\hline & China & & & & & & & & & & \\
\hline 94 & Mainland & 46,439 & 44,410 & 94,367 & 84,251 & 68,391 & 58,496 & 65,089 & $73,215^{r}$ & 124,713 & 183,609 \\
\hline 95 & Hong Kong & 33,972 & 43,111 & 44,481 & 42,148 & 46,210 & 40,683 & 40,680 & 40,579 & 52,513 & 61,322 \\
\hline 96 & India & 13,702 & 18,808 & 18,213 & 12,226 & 12,930 & 14,805 & 15,644 & 17,483 & 18,201 & 21,461 \\
\hline 97 & Indonesia & 4,212 & 4,386 & 5,212 & 3,768 & 3,113 & 4,723 & 5,099 & $6,558^{r}$ & 8,271 & 6,068 \\
\hline 98 & Israel .... & 9,802 & 7,318 & 7,770 & 9,742 & 11,862 & 12,085 & 10,079 & 8,606 & 11,248 & 14,635 \\
\hline 99 & Japan & 156,245 & 127,606 & 146,350 & 133,294 & 132,369 & 131,453 & 136,027 & 142,044 & 150,036 & 166,695 \\
\hline 100 & Korea (South) & 27,094 & 27,786 & 34,769 & 21,579 & 21,743 & 21,607 & 21,604 & $20,155^{r}$ & 16,452 & 14,308 \\
\hline 101 & Philippines & 3,776 & 3,852 & 4,834 & 3,308 & 2,928 & 3,698 & 3,596 & 3,694 & 4,101 & 6,456 \\
\hline 102 & $\mathrm{Ta}$ & 23,252 & 22,917 & 26,056 & 24,254 & 23,990 & 22,159 & 22,712 & $22,502^{r}$ & 29,912 & 33,750 \\
\hline 103 & Thailand & 9,961 & 8,318 & 14,188 & 15,008 & 19,679 & 17,837 & 18,919 & $18,005^{r}$ & 14,364 & 18,727 \\
\hline 104 & Middle Eastern oil-exporting countries ${ }^{16}$ & 49,463 & 69,492 & 80,133 & 93,427 & 105,057 & 105,342 & 112,791 & 125,309 & 121,778 & 125,989 \\
\hline 105 & Other $\ldots \ldots \ldots \ldots \ldots \ldots \ldots \ldots$ & 30,274 & 44,740 & 50,688 & 51,698 & 47,147 & 48,024 & 47,805 & $48,822^{r}$ & 47,749 & 52,207 \\
\hline 106 & Africa & 20,095 & 14,781 & 25,816 & 35,153 & 36,867 & 36,984 & 39,480 & 21,525 & 24,787 & 29,648 \\
\hline 107 & Egypt & 4,953 & 2,252 & 3,682 & 4,781 & 4,035 & 4,486 & 5,101 & 3,855 & 7,321 & 10,536 \\
\hline 108 & Morocco & 138 & 198 & 180 & 211 & 170 & 274 & 349 & 242 & 532 & 542 \\
\hline 109 & South Africa & 3,049 & 1,396 & 1,629 & 2,985 & 3,384 & 2,964 & 2,662 & 2,991 & 2,967 & 3,174 \\
\hline & Oil-ex porting countries ${ }^{17} \ldots$ & 6,858 & 4,438 & 6,117 & 3,727 & 4,168 & 4,665 & 5,405 & 4,315 & 3,965 & 4,351 \\
\hline 111 & Other $\ldots \ldots \ldots \ldots \ldots$ & 5,097 & 6,497 & 14,208 & 23,449 & 25,110 & 24,595 & 25,963 & 10,122 & 10,002 & 11,045 \\
\hline 112 & Other countries & 21,242 & 30,620 & 18,384 & 29,020 & 31,944 & 25,014 & 26,394 & 22,953 & 22,354 & 24,141 \\
\hline 113 & Australia & 17,769 & 25,277 & 14,130 & 24,823 & 27,783 & 21,037 & 22,220 & 17,387 & 17,681 & 18,889 \\
\hline 114 & - New Zealand & 3,007 & 4,505 & 3,110 & 3,046 & 3,175 & 3,213 & 3,059 & 4,772 & 3,990 & 4,540 \\
\hline 115 & All other .. & 466 & 838 & 1,144 & 1,151 & 986 & 764 & 1,115 & 794 & 683 & 712 \\
\hline 116 & 1 regional organizations & 20,793 & 29,425 & 64 & 24,776 & 28 & 24,398 & $26,158^{r}$ & 81 & 23,672 & 24,183 \\
\hline & International ${ }^{18}$ & 15,684 & 25,202 & 23,107 & 20,413 & 23,771 & 19,704 & $21,371^{r}$ & 23,324 & 18,304 & 20,275 \\
\hline 118 & Regional $^{19}$ & 5,109 & 4,223 & 4,057 & 4,363 & 4,304 & 4,694 & 4,787 & 4,357 & 5,368 & 3,908 \\
\hline
\end{tabular}

1. Reporting banks include all types of depository institutions as well as some banks/ financial holding companies and brokers and dealers. Excludes bonds and notes of maturities longer than one year. Effective February 2003, coverage is expanded to include liabilities of brokers and dealers to affiliated foreign offices.

2. Non-negotiable deposits and brokerage balances.

3. Data available beginning January 2001

4. Financial claims on residents of the United States, other than long-term securities, held by or through reporting banks for foreign customers. Effective February 2003, also includes loans to U.S. residents in managed foreign offices of U.S. reporting institutions.

5. Includes nonmarketable certificates of indebtedness and Treasury bills issued to official institutions of foreign countries.

6. Principally bankers acceptances, commercial paper, negotiable time certificates of deposit, and short-term agency securities.

. Data available beginning January 2001

8. Principally the International Bank for Reconstruction and Development, the InterAmerican Development Bank, and the Asian Development Bank. Excludes "holdings of dollars" of the International Monetary Fund. Beginning with data for June 2006, also includes the Bank for International Settlements.

9. Foreign central banks and foreign central governments. Before June 2006, also includes the Bank for International Settlements.

10. Excludes central banks, which are included in "Official institutions." Includes positions with affiliated banking offices also included in memo line (44) above.

11. As of February 2003, includes positions with affiliated non-banking offices also included in memo line (44) above.

12. For U.S. banks, includes amounts owed to own foreign branches and foreign subsidiaries consolidated in the quarterly Consolidated Reports of Condition filed with bank regulatory agencies. For agencies, branches, and majority-owned subsidiaries of foreign banks, consists principally of amounts owed to the head office or parent foreign office, and to foreign branches, agencies, or wholly owned subsidiaries of the head office or parent foreign bank.
Effective February 2003, includes amounts owed to affiliated foreign offices of U.S. brokers Effective Febring

and dealers.
13. In February 2003, Yugoslavia changed its name to Serbia and Montenegro. Data for other entities of the former Yugoslavia recognized as independent states by the United States are reported under "Other Europe."

14. For data prior to June 2006, also includes the Bank for International Settlements and the European Central Bank.

15. As of May 2004, the European Union includes Austria, Belgium, Cyprus, the Czech Republic, Denmark, Estonia, Finland, France, Germany, Greece, Hungary, Ireland, Italy, Latvia, Lithuania, Luxembourg, Malta, the Netherlands, Poland, Portugal, Slovakia, Slovenia, Spain, Sweden, and the United Kingdom. Data available beginning in June 2006. As of January 2007, also includes Bulgaria and Romania.

16. Comprises Bahrain, Iran, Iraq, Kuwait, Oman, Qatar, Saudi Arabia, and United Arab Emirates (Trucial States)

17. Comprises Algeria, Gabon, Libya, and Nigeria

18. Principally the International Bank for Reconstruction and Development. Excludes "holdings of dollars" of the International Monetary Fund. Beginning with data for June 2006, also includes the Bank for International Settlements.

19. African, Asian, Caribbean, European, Latin American, and Middle Eastern regional organizations. 
48 Federal Reserve Bulletin Statistical Supplement $\square$ December 2008

3.18 BANKS' OWN CLAIMS ON FOREIGNERS Reported by Banks in the United States ${ }^{1}$ Payable in U.S. dollars

Millions of dollars, end of period

\begin{tabular}{|c|c|c|c|c|c|c|c|c|c|c|c|}
\hline \multirow{2}{*}{\multicolumn{2}{|c|}{ Area or country }} & \multirow{2}{*}{2005} & \multirow{2}{*}{2006} & \multirow{2}{*}{2007} & \multicolumn{7}{|c|}{2008} \\
\hline & & & & & Apr. & May & June & July & Aug. & Sept. & Oct. $^{p}$ \\
\hline & Total, all foreigners & $1,864,834$ & $2,291,340$ & $2,791,032$ & $2,980,086$ & $2,987,770$ & $2,855,584$ & $2,874,606^{\mathrm{r}}$ & $2,887,355^{r}$ & $2,781,644^{r}$ & $2,690,423$ \\
\hline & Foreign countries & $1,857,584$ & $2,282,166$ & $2,780,727$ & $2,970,340$ & $2,980,137$ & $2,850,292$ & $2,868,459^{r}$ & $2,881,301^{r}$ & $2,776,233^{r}$ & $2,685,948$ \\
\hline & Europe & 918,660 & $1,188,919$ & $1,587,218$ & $1,725,855$ & $1,680,918$ & $1,593,221$ & $1,584,310$ & $1,621,268^{r}$ & $1,607,640^{r}$ & $1,511,148$ \\
\hline & Austria & 4,139 & 4,277 & 4,055 & 4,998 & 5,335 & 5,416 & 5,717 & $8,435^{r}$ & 4,624 & 4,329 \\
\hline & Belgium & 11,900 & 13,592 & 20,566 & 40,457 & 33,888 & 31,029 & 26,476 & $32,824^{r}$ & 21,730 & 18,653 \\
\hline 6 & Denmark & 864 & 1,156 & 2,828 & 6,451 & 6,159 & 4,021 & 5,804 & 4,188 & 2,321 & 2,485 \\
\hline 7 & Finland . . & 9,247 & 9,434 & 28,445 & 32,133 & 27,073 & 29,854 & 22,469 & 24,164 & $25,807^{r}$ & 22,106 \\
\hline 8 & France. & 88,873 & 112,406 & 162,295 & 201,697 & 188,786 & 181,173 & 190,233 & $193,272^{r}$ & $171,946^{\circ}$ & 167,166 \\
\hline 9 & Germany . & 30,027 & 18,189 & 33,725 & 51,589 & 53,633 & 57,384 & 47,686 & $47,820^{r}$ & 49,736 & 40,699 \\
\hline 10 & Greece .. & 97 & 250 & 110 & 341 & 347 & 275 & 251 & $136^{\mathrm{r}}$ & 149 & 378 \\
\hline 11 & Ireland & 16,426 & 24,304 & 45,960 & 67,368 & 73,668 & 68,574 & 66,092 & $70,475^{r}$ & 63,668 & 68,274 \\
\hline 12 & $\ldots \ldots \ldots \ldots$ & 18,482 & 30,991 & 35,870 & 47,231 & 49,445 & 48,224 & 52,376 & $57,180^{r}$ & 49,844 & 40,273 \\
\hline 13 & Luxembourg. & 8,201 & 7,144 & 13,260 & 9,142 & 8,366 & 10,767 & 9,216 & $8,958^{\prime}$ & 11,508 & 10,660 \\
\hline 14 & Netherlands $\ldots \ldots \ldots \ldots \ldots \ldots \ldots \ldots \ldots$ & 20,958 & 29,578 & 52,122 & 53,152 & 54,966 & 59,290 & 53,642 & $57,473^{r}$ & 46,498 & 44,545 \\
\hline 15 & Norway ..... & 14,688 & 31,032 & 22,684 & 13,820 & 15,412 & 15,073 & 16,810 & 16,413 & 23,912 & 14,068 \\
\hline 16 & Portugal & 832 & 924 & 1,364 & 1,552 & 1,626 & 1,417 & 1,745 & $1,433^{r}$ & 1,370 & 1,359 \\
\hline 17 & Russia . . & 1,264 & 1,745 & 1,800 & 1,797 & 2,033 & 2,244 & 2,667 & 2,455 & 2,518 & 2,532 \\
\hline 18 & Spain ... & 8,372 & 9,834 & 20,448 & 49,123 & 55,160 & 47,496 & 47,630 & $45,796^{r}$ & $46,326^{r}$ & 40,656 \\
\hline 19 & $\ldots \ldots \ldots \ldots \ldots \ldots$ & 9,452 & 8,907 & 7,279 & 9,431 & 8,576 & 7,433 & 7,032 & 8,132 & 7,899 & 7,139 \\
\hline 20 & Switzerland & 143,892 & 105,368 & 191,970 & 186,320 & 145,397 & 116,675 & 106,351 & 106,301 & 107,312 & 121,319 \\
\hline 21 & Turkey $\ldots$ & 3,270 & 3,741 & 3,426 & 3,658 & 3,663 & 3,675 & 3,928 & 3,839 & 3,782 & 3,741 \\
\hline 22 & United Kingdom & 487,492 & 732,430 & 900,349 & 911,716 & 916,714 & 874,381 & 890,070 & 905,899 & 947,929 & 884,646 \\
\hline 23 & Channel Islands and Isle of Man & 32,566 & 36,893 & 24,357 & 12,201 & 8,733 & 6,730 & 5,110 & 4,883 & 4,356 & 7,147 \\
\hline 24 & Other Europe and other former U.S.S.R. ${ }^{2}$.. & 7,618 & 6,724 & 14,306 & 21,678 & 21,938 & 22,090 & 23,003 & 21,192 & 14,405 & 8,973 \\
\hline & MEMo & & & & & & & & & & \\
\hline 25 & European Union ${ }^{3}$ & n.a. & $1,008,255$ & $1,341,415$ & $1,506,222$ & $1,503,879$ & $1,446,999$ & $1,447,679$ & $1,485,640^{r}$ & $1,464,034 r$ & $1,360,526$ \\
\hline 26 & Canada & 64,104 & 71,325 & 85,145 & 91,367 & 92,996 & 88,786 & 81,114 & 91,539 & $94,104 r$ & 85,654 \\
\hline 27 & Latin America & 51,170 & 59,195 & 83,042 & 83,458 & 96,073 & 96,734 & 97.576 & 103,794 & $92,891^{r}$ & 95,316 \\
\hline 28 & Argentina & 2,290 & 2,763 & 3,978 & 4,825 & 3,866 & 4,224 & 4,763 & 5,356 & $4,816^{r}$ & 4,806 \\
\hline 29 & Brazil ... & 15,111 & 19,894 & 30,340 & 24,761 & 38,626 & 37,796 & 37,280 & 41,787 & $31,086^{r}$ & 33,830 \\
\hline 30 & Chile. . & 6,642 & 6,689 & 8,849 & 9,787 & 10,192 & 10,353 & 10,524 & 10,974 & 11,078 & 10,021 \\
\hline 31 & Colombia & 2,438 & 2,900 & 3,567 & 3,524 & 3,527 & 3,625 & 3,529 & 3,591 & 3,770 & 3,712 \\
\hline 32 & $\ldots \ldots \ldots \ldots \ldots$ & 582 & 604 & 962 & 811 & 835 & 786 & 778 & 761 & 831 & 826 \\
\hline 33 & . $\ldots \ldots \ldots \ldots \ldots \ldots$ & 872 & 1,031 & 1,314 & 1,296 & 1,311 & 1,377 & 1,323 & 1,387 & 1,355 & 1,349 \\
\hline 34 & Mexico $\ldots \ldots \ldots \ldots \ldots \ldots \ldots \ldots \ldots \ldots \ldots$ & 14,601 & 16,569 & 21,783 & 24,906 & 23,752 & 23,902 & 24,757 & 25,298 & 25,444 & 25,727 \\
\hline 35 & $\ldots \ldots \ldots$ & 2,076 & 2,316 & 3,859 & 4,408 & 4,588 & 5,020 & 4,883 & 5,001 & 4,842 & 5,395 \\
\hline 36 & Peru ... & 1,226 & 1,446 & 2,995 & 3,857 & 4,144 & 4,517 & 4,239 & 4,586 & 4,540 & 4,440 \\
\hline 37 & Uruguay & 464 & 355 & 338 & 271 & 311 & 297 & 291 & 320 & 333 & 342 \\
\hline 38 & Venezuela & 2,273 & 2,281 & 2,335 & 1,898 & 1,956 & 1,873 & 1,819 & 1,774 & 1,805 & 1,793 \\
\hline 39 & Other Latin America ${ }^{4}$. & 2,595 & 2,347 & 2,722 & 3,114 & 2,965 & 2,964 & 3,390 & 2,959 & 2,991 & 3,075 \\
\hline 40 & Caribbean & 620,474 & 724,316 & 801,309 & 856,318 & 892,761 & 865,530 & $884,107^{r}$ & $869,000^{r}$ & $816,595^{r}$ & 828,655 \\
\hline 41 & Bahamas & 113,458 & 120,904 & 151,187 & 147,173 & 154,129 & 147,091 & 157,522 & 152,480 & 141,424 & 174,971 \\
\hline 42 & Bermuda. & 17,846 & 17,777 & 10,651 & 16,110 & 17,832 & 13,289 & 14,055 & 11,876 & 13,178 & 9,767 \\
\hline 43 & British Virgin Islands ${ }^{4}$ & n.a. & 2,807 & 3,328 & 3,881 & 3,905 & 3,996 & 4,161 & 5,705 & 5,324 & 4,776 \\
\hline 44 & Cayman Islands... & 475,227 & 572,273 & 622,637 & 669,531 & 701,914 & 686,156 & 691,654 & $683,884^{r}$ & $637,837^{r}$ & 616,495 \\
\hline 45 & Jamaica ....... & 444 & 669 & 657 & 742 & 769 & 818 & 811 & 814 & 808 & 836 \\
\hline 46 & Netherlands Antilles. & 4,444 & 2,484 & 4,114 & 4,409 & 4,229 & 4,053 & 3,656 & 3,530 & 3,400 & 3,493 \\
\hline 47 & Trinidad and Tobago & 907 & 1,055 & 673 & 855 & 766 & 807 & 755 & 864 & 592 & 671 \\
\hline 48 & Other Caribbean ${ }^{4}$. & 8,148 & 6,347 & 8,062 & 13,617 & 9,217 & 9,320 & 11,493 & 9,847 & 14,032 & 17,646 \\
\hline 49 & Asia & 190,610 & 221,858 & 185,695 & 169,445 & 172,807 & 158,654 & 171,371 & $165,375^{r}$ & $138,417^{r}$ & 139,697 \\
\hline & China & & & & & & & & & & \\
\hline 50 & Mainland & 14,807 & 15,448 & 18,489 & 15,564 & 23,032 & 19,501 & 21,702 & 23,653 & 10,497 & 3,770 \\
\hline 51 & Hong Kong . ....... & 8,412 & 6,888 & 8,820 & 9,269 & 8,945 & 8,886 & 9,481 & 10,056 & 13,884 & 11,094 \\
\hline 52 & India $\ldots \ldots \ldots \ldots \ldots$ & 2,518 & 2,827 & 4,385 & 4,293 & 5,352 & 5,654 & 6,638 & 5,983 & 5,882 & 5,146 \\
\hline 53 & Indonesia & 440 & 519 & 985 & 1,086 & 1,329 & 1,144 & 1,062 & 1,088 & 1,111 & 1,058 \\
\hline 54 & Istael ..... & 4,288 & 5,319 & 3,724 & 3,387 & 5,419 & 4,109 & 6,618 & 5,564 & 2,879 & 1,848 \\
\hline 55 & Japan & 106,377 & 140,329 & 83,652 & 84,316 & 78,836 & 74,838 & 79,227 & 70,620 & 69,402 & 81,667 \\
\hline 56 & Korea (South). & 17,254 & 24,484 & 27,383 & 22,182 & 21,090 & 19,464 & 18,283 & $17,262^{r}$ & $13,773^{r}$ & 13,797 \\
\hline 57 & Philippines . . . . . . & 1,790 & 996 & 1,207 & 1,133 & 1,028 & 1,448 & 1,214 & 993 & 864 & 850 \\
\hline 58 & Taiwan ........... & 8,626 & 3,166 & 1,222 & 1,548 & 1,207 & 1,634 & 1,205 & 1,165 & 1,954 & 1,135 \\
\hline 59 & Thailand & 7,796 & 5,729 & 5,960 & 4,045 & 3,629 & 1,116 & 2,930 & 1,134 & 90 & 109 \\
\hline 60 & Middle Eastern oil-ex porting countries ${ }^{5}$ & 12,330 & 10,579 & 23,160 & 15,596 & 16,109 & 13,265 & 13,670 & 17,305 & 10,989 & 11,234 \\
\hline 61 & Other & 5,972 & 5,574 & 6,708 & 7,026 & 6,831 & 7,595 & 9,341 & 10,552 & 7,092 & 7,989 \\
\hline 62 & Africa & 1,621 & 1,853 & 8,164 & 16,679 & 17,578 & 18,614 & 20,297 & 2,838 & 3,968 & 2,835 \\
\hline 63 & Egypt & 422 & 597 & 312 & 356 & 367 & 367 & 1,353 & 417 & 397 & 358 \\
\hline 64 & Morocco & 63 & 56 & 27 & 60 & 18 & 30 & 11 & 6 & 8 & 3 \\
\hline 65 & South Africa & 331 & 255 & 493 & 562 & 450 & 374 & 387 & 532 & 895 & 519 \\
\hline & Oil-exporting countries ${ }^{6}$ & 317 & 403 & 442 & 891 & 608 & 696 & 950 & 940 & 964 & 656 \\
\hline 67 & Other & 488 & 542 & 6,890 & 14,810 & 16,135 & 17,147 & 17,596 & 943 & 1,704 & 1,299 \\
\hline 68 & Other countries. & 10,945 & 14,700 & 30,154 & 27,218 & 27,004 & 28,753 & 29,684 & 27,487 & 22,618 & 22,643 \\
\hline 69 & Australia ........ & 10,226 & 13,195 & 28,716 & 25,527 & 25,159 & 27,317 & 27,926 & 25,799 & 21,276 & 21,136 \\
\hline 70 & New Zealand ....... & 541 & 1,263 & 1,122 & 1,236 & 1,440 & 1,012 & 1,298 & 1,223 & 817 & 921 \\
\hline & All other $\ldots \ldots \ldots \ldots \ldots \ldots$ & 178 & 242 & 316 & 455 & 405 & 424 & 460 & 465 & 525 & 586 \\
\hline 72 & International and regional organizations? & 7,250 & 9,174 & 10,305 & 9,746 & 7,633 & 5,292 & 6,147 & $6,054^{r}$ & 5,411 & 4,475 \\
\hline
\end{tabular}

1. Reporting banks include all types of depository institutions as well as bank/financial holding companies and brokers and dealers. Effective February 2003, coverage is expanded to include claims of brokers and dealers on affiliated foreign offices and cross-border brokerage

2. For data prior to June 2006, also includes the Bank for International Settlements and the
. European Central Bank.

3. As of May 2004, the European Union includes Austria, Belgium, Cyprus, the Czech Republic, Denmark, Estonia, Finland, France, Germany, Greece, Hungary, Ireland, Italy, Latvia, Lithuania, Luxembourg, Malta, the Netherlands, Poland, Portugal, Slovakia, Slovenia, Spain, Sweden, and the United Kingdom. Data available beginning in June 2006. As of
January 2007, also includes Bulgaria and Romania.

4. Before June 2006, data for the British Virgin Islands were included in "Other Caribbean."

5. Comprises Bahrain, Iran, Iraq, Kuwait, Oman, Qatar, Saudi Arabia, and United Arab Emirates (Trucial States).

6. Comprises Algeria, Gabon, Libya, and Nigeria.

7. Includes the International Bank for Reconstruction and Development, as well as African, Asian, Caribbean, European, Latin American, and Middle Eastern regional organizations. Beginning with data for June 2006 , also includes the Bank for International Settlements. 
3.19 BANKS' OWN AND DOMESTIC CUSTOMERS' CLAIMS ON FOREIGNERS Reported by Banks in the United States' Payable in U.S. dollars

Millions of dollars, end of period

\begin{tabular}{|c|c|c|c|c|c|c|c|c|c|c|}
\hline \multirow{2}{*}{ Type of claim } & \multirow{2}{*}{2005} & \multirow{2}{*}{2006} & \multirow{2}{*}{2007} & \multicolumn{7}{|c|}{2008} \\
\hline & & & & Apr. & May & June & July ${ }^{r}$ & Aug. & Sept. & Oct. $^{p}$ \\
\hline 1 Total claims reported by banks ... & $2,344,155$ & $2,944,476$ & $3,547,969$ & . & $\cdots$ & $3,554,284^{r}$ & .. & ... & $3,423,529$ & . \\
\hline 2 Banks' own claims on foreigners & $1,864,834$ & $2,291,340$ & $2,791,032$ & $2,980,086$ & $2,987,770$ & $2,855,584$ & $2,874,606$ & $2,887,355$ & $2,781,644^{r}$ & $2,690,423$ \\
\hline 3 Foreign official institutions ${ }^{2}$... & 72,919 & 98,010 & 108,326 & 92,643 & 117,571 & 96,578 & 104,736 & 109,073 & $76,817^{r}$ & 58,037 \\
\hline $4 \quad$ Foreign banks ${ }^{3}, \ldots \ldots \ldots$. & $1,391,775$ & $1,662,805$ & $2,067,163$ & $2,234,603$ & $2,230,628$ & $2,134,480$ & $2,144,305$ & $2,166,694$ & $2,115,684^{r}$ & $2,087,529$ \\
\hline $5 \quad$ Other foreigners $^{4}$ & 400,140 & 530,525 & 615,543 & 652,840 & 639,571 & 624,526 & 625,565 & 611,588 & $589,143^{r}$ & 544,857 \\
\hline 6 Claims on banks' domestic customers ${ }^{5}$ & 479,321 & 653,136 & 756,937 & . & . & $698,700^{\circ}$ & . & . & 641,885 & . \\
\hline $7 \quad$ Non-negotiable deposits $\ldots \ldots \ldots$ & 227,685 & 277,734 & $394,043^{r}$ & & $\ldots$ & 339,572 & & & 308,280 & . \\
\hline 8 Negotiable CDs ..... & 91,196 & 168,304 & 167,311 & . & $\ldots$ & 172,688 & $\ldots$ & $\ldots$ & 171,364 & . \\
\hline 9 Other short-term negotiable instruments ${ }^{6}$ & 140,863 & 185,134 & 173,423 & & $\cdots$ & 171,143 & . & $\ldots$ & 146,545 & . \\
\hline $10 \quad$ Other claims $\ldots \ldots \ldots \ldots \ldots \ldots \ldots$ & 19,577 & 21,964 & $22,160^{r}$ & & $\therefore$ & $15,297^{r}$ & $\therefore$ & $\ldots$ & 15,696 & $\therefore$ \\
\hline MEMo & & & & & & & & & & \\
\hline 11 Non-negotiable deposits? & 748,320 & 923,958 & 978,182 & $1,076,657$ & $1,106,976$ & $1,092,847$ & $1,076,920$ & $1,072,985$ & 991,554 & $1,021,929$ \\
\hline 12 Negotiable CDs $^{7} \ldots \ldots \ldots$ & 2,414 & 6,272 & 5,830 & 2,190 & 3,277 & 2,610 & 2,692 & 2,653 & 2,256 & 616 \\
\hline $\begin{array}{c}13 \text { Other short-term negotiable } \\
\text { instruments? }\end{array}$ & 7,324 & 9,236 & 42,252 & 42,586 & 40,321 & 39,773 & 45,096 & 38,085 & 40,075 & 42,480 \\
\hline 14 Other claims ${ }^{7} \ldots$.... & $1,106,776$ & $1,351,874$ & $1,764,768$ & $1,858,653$ & $1,837,196$ & $1,720,354$ & $1,749,898$ & $1,773,632$ & $1,747,759^{r}$ & $\begin{array}{r}+2,400 \\
1,625,398\end{array}$ \\
\hline 15 Own foreign offices ${ }^{8} \ldots$ & $1,304,277$ & $1,639,474$ & $1,928,520$ & $2,070,008$ & $2,050,758$ & $1,980,944$ & $1,948,816$ & $1,957,281$ & $1,952,210^{r}$ & $1,866,243$ \\
\hline $\begin{array}{r}16 \text { Loans collateralized by repurchase } \\
\text { agreements }{ }^{9} \ldots \ldots \ldots \ldots \ldots\end{array}$ & 482,090 & 664,373 & 764,821 & 814,026 & 813,211 & 742,200 & 795,782 & 807.559 & 748,798 & 672,962 \\
\hline
\end{tabular}

1. For banks' claims, data are monthly; for claims of banks' domestic customers, data are for the quarter ending with the month indicated.

Reporting banks include all types of depository institutions as well as banks/financial holding companies and brokers and dealers. Effective February 2003, coverage is expanded to include claims of brokers and dealers on affiliated foreign offices and cross-border balances. 2. Prior to February 2003 , reflects claims on all foreign public borrowers.

3. Includes positions with affiliated banking offices also included in memo line (15) above. 4. As of February 2003, includes positions with affiliated non-banking offices also included in memo line (15) above.

5. Assets held by reporting banks in the accounts of their domestic customers. Effective March 2003, includes balances in off-shore sweep accounts.
6. Primarily bankers acceptances and commercial paper. Prior to February 2003, also includes negotiable certificates of deposit

. Data available beginning February 2003.

8. For U.S. banks, includes amounts due from own foreign branches and foreign subsidiaries consolidated in quarterly Consolidated Reports of Condition filed with bank regulatory agencies. For agencies, branches, and minority-owned subsidiaries of foreign banks, consists principally of amounts due from the head office or parent foreign bank, and from foreign branches, agencies, or wholly owned subsidiaries of the head office or parent foreign bank. Effective February 2003, includes amounts due from affiliated foreign offices of U.S. brokers and dealers.

9. Data available beginning January 2001 
$50 \quad$ Federal Reserve Bulletin Statistical Supplement $\square$ December 2008

3.22 LIABILITIES TO UNAFFILIATED FOREIGNERS Reported by Nonbanking Business Enterprises in the United States Millions of dollars, end of period

\begin{tabular}{|c|c|c|c|c|c|c|c|c|c|c|}
\hline \multirow{2}{*}{\multicolumn{2}{|c|}{ Type of liability, and area or country }} & \multirow{2}{*}{2004} & \multirow{2}{*}{2005} & \multirow{2}{*}{2006} & \multicolumn{3}{|c|}{2007} & \multicolumn{3}{|c|}{2008} \\
\hline & & & & & June & Sept. & Dec. & Mar. & June & Sept. ${ }^{p}$ \\
\hline & Total & 92,009 & 76,710 & 89,217 & 106,508 & 112,853 & $103,835^{\mathrm{r}}$ & $111,287^{r}$ & $107,533^{\mathrm{r}}$ & 103,044 \\
\hline & By type & & & & & & & & & \\
\hline & Financial liabilities & 62,847 & 39,249 & 48,712 & 52,649 & 55,051 & 47,919 & 46,175 & 39,285 & 36,058 \\
\hline & Short-term negotiable securities ${ }^{1}$ & 11,759 & 9,050 & 11,617 & 6,783 & 4,663 & 4,923 & 7,751 & 6,374 & 6,163 \\
\hline & $\begin{array}{l}\text { Other liabilities }{ }^{\prime} \ldots \ldots \ldots \ldots \ldots \ldots \ldots \\
\text { Of which: }\end{array}$ & 51,088 & 30,199 & 37,095 & 45,866 & 50,388 & 42,996 & 38,424 & 32,911 & 29,895 \\
\hline 5 & Borrowings $1 \ldots \ldots \ldots$ & n.a. & n.a. & 10,120 & 12,219 & 13,536 & 14,130 & 15,015 & 14,086 & 15,269 \\
\hline 6 & Repurchase agreements $^{1}$ & n.a. & n.a. & 18,573 & 24,908 & 15,048 & 7,625 & 5,027 & 4,614 & 3,906 \\
\hline & By currency & & & & & & & & & \\
\hline 7 & U.S. dollars & 29,575 & 24,003 & 35,033 & 31,589 & 29,103 & 26,474 & 23,995 & 21,646 & 23,021 \\
\hline 8 & Foreign currency ${ }^{2}$. & 33,272 & 15,246 & 13,679 & 21,060 & 25,948 & 21,445 & 22,180 & 17,639 & 13,037 \\
\hline 9 & Canadian dollars & 2,399 & 2,354 & 2,806 & 1,328 & 834 & 1,193 & 899 & 879 & 870 \\
\hline 10 & Euros $\ldots \ldots \ldots$ & 9,067 & 4,052 & 4,629 & 11,414 & 13,006 & 8,496 & 9,968 & 8,893 & 5,381 \\
\hline 11 & United Kingdom pounds sterling & 18,337 & 3,169 & 4,024 & 4,044 & 4,007 & 3,948 & 3,967 & 4,319 & 3,190 \\
\hline 12 & Japanese yen $\ldots \ldots \ldots \ldots$. & 1,564 & 2,018 & 1,393 & 2,397 & 3,319 & 3,536 & 3,849 & 2,335 & 2,694 \\
\hline 13 & All other currencies .. & 1,905 & 3,653 & 827 & 1,877 & 4,782 & 4,272 & 3,497 & 1,213 & 902 \\
\hline \multicolumn{2}{|r|}{ By area or country } & & & & & & & & & \\
\hline 14 & Europe & 38,690 & 22,697 & 30,184 & 34,443 & 35,076 & 28,175 & 26,207 & 22,846 & 17,909 \\
\hline 15 & Belgium-Luxembourg & 775 & 342 & 936 & 863 & 460 & 467 & 225 & 985 & 701 \\
\hline 16 & France $\ldots \ldots \ldots \ldots$ & 1,349 & 761 & 995 & 621 & 1,466 & 1,453 & 1,522 & 485 & 590 \\
\hline 17 & Germany & 2,911 & 2,533 & 11,174 & 6,264 & 6,164 & 2,940 & 1,843 & 1,553 & 1,739 \\
\hline 18 & Netherlands .. & 363 & 406 & 1,183 & 204 & 242 & 256 & 285 & 284 & 238 \\
\hline 19 & Switzerland ... & 514 & 124 & 346 & 313 & 289 & 287 & 90 & 91 & 112 \\
\hline 20 & United Kingdom $\ldots \ldots \ldots \ldots \ldots \ldots \ldots \ldots \ldots \ldots \ldots \ldots \ldots \ldots \ldots \ldots \ldots$ & 29,473 & 12,712 & 14,308 & 24,956 & 23,664 & 20,230 & 21,680 & 18,638 & 13,964 \\
\hline 21 & $\begin{array}{l}\text { MEMO: } \\
\text { Euro area }\end{array}$ & 7,049 & 5,955 & 14,659 & 8,567 & 9,496 & 6,369 & 4,116 & 3,892 & 3,588 \\
\hline 22 & Canada & 2,433 & 2,530 & 3,986 & 2,361 & 3,232 & 2,104 & 1,964 & 1,391 & 1,311 \\
\hline 23 & Latin America and Caribbean & 16,196 & 7,603 & 12,435 & 12,645 & 14,196 & 15,017 & 15,106 & 13,081 & 14,096 \\
\hline 24 & 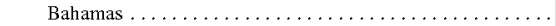 & & 0 & 0 & 0 & 7 & 0 & 0 & 1 & 0 \\
\hline 25 & Bermuda & 8,715 & 991 & 0 & 0 & 1 & 0 & 58 & 93 & 65 \\
\hline 26 & Brazil .. & 208 & 70 & 23 & 15 & 23 & 29 & 26 & 64 & 37 \\
\hline 27 & British West Indies ${ }^{4}$ & n.a. & n.a. & n.a. & n.a. & n.a. & na. & n.a. & n.a. & n.a. \\
\hline 28 & Cayman Islands ... & 7,178 & 6,446 & 12,265 & 12,388 & 13,994 & 14,802 & 14,833 & 12,635 & 13,743 \\
\hline 29 & Mexico ......... & 26 & 25 & 30 & 35 & 27 & 28 & 36 & 70 & 77 \\
\hline 30 & Venezuela.... . & 18 & 1 & 0 & 14 & 16 & 18 & 16 & 13 & 13 \\
\hline 31 & Asia & 4,724 & 5,323 & 1,924 & 3,106 & 2,445 & 2,470 & 2,688 & 1,694 & 2,578 \\
\hline 32 & Japan & 1,648 & 1,383 & 1,346 & 1,392 & 1,676 & 1,563 & 1,864 & 810 & 1,640 \\
\hline 33 & Middle Eastern oil-exporting countries ${ }^{5}$ & 36 & 173 & 100 & 1,088 & 56 & 53 & 123 & 50 & 88 \\
\hline 34 & Africa . & 131 & 997 & 31 & 27 & 26 & 31 & 88 & 96 & 103 \\
\hline 35 & Oil-exporting countries & 94 & 97 & 0 & 0 & 0 & 0 & 0 & 0 & 4 \\
\hline 36 & All other ${ }^{7}$ & 673 & 99 & 152 & 67 & 76 & 122 & 122 & 177 & 61 \\
\hline
\end{tabular}


3.22 LIABILITIES TO UNAFFILIATED FOREIGNERS Reported by Nonbanking Business Enterprises in the United States-Continued Millions of dollars, end of period

\begin{tabular}{|c|c|c|c|c|c|c|c|c|c|c|}
\hline \multirow{2}{*}{\multicolumn{2}{|c|}{ Type of liability, and area or country }} & \multirow{2}{*}{2004} & \multirow{2}{*}{2005} & \multirow{2}{*}{2006} & \multicolumn{3}{|c|}{2007} & \multicolumn{3}{|c|}{2008} \\
\hline & & & & & June & Sept. & Dec. & Mar. & June & Sept. ${ }^{P}$ \\
\hline 37 & Commercial liabilities & 29,162 & 37,461 & 40,505 & 53,859 & 57,802 & $55,916^{r}$ & $65,112^{r}$ & $68,248^{\circ}$ & 66,986 \\
\hline 38 & Trade payables ...... & 18,181 & 23,050 & 25,673 & 28,237 & 29,322 & 27,866 & 32,272 & 37,772 & 33,416 \\
\hline 39 & 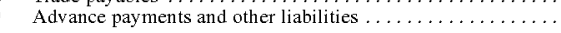 & 10,981 & 14,411 & 14,832 & 25,622 & 28,480 & $28,050^{\circ}$ & $32,840^{r}$ & $30,476^{r}$ & 33,570 \\
\hline \multicolumn{11}{|c|}{ By currency } \\
\hline 40 & Payable in U.S. dollars & 25,811 & 34,725 & 37,298 & 50,440 & 54,969 & 52,687 & $61,122^{\ulcorner}$ & 65,066 & 64,320 \\
\hline 41 & Payable in foreign currencies ${ }^{2}$ & 3,351 & 2,736 & 3,207 & 3,419 & 2,833 & 3,229 & 3,990 & 3,182 & 2,666 \\
\hline 42 & Canadian dollars ......... & 224 & 171 & 730 & 707 & 666 & 969 & 1,756 & 911 & 1,025 \\
\hline 43 & Euros ............ & 1,058 & 989 & 610 & 617 & 482 & 579 & 528 & 731 & 370 \\
\hline 44 & United Kingdom pounds sterling & 704 & 471 & 470 & 541 & 300 & 319 & 294 & 270 & 158 \\
\hline 45 & Japanese yen $\ldots \ldots \ldots \ldots \ldots$ & 296 & 308 & 377 & 381 & 354 & 372 & 400 & 262 & 254 \\
\hline 46 & All other currencies & 1,069 & 797 & 1,020 & 1,173 & 1,031 & 990 & 1,012 & 1,008 & 859 \\
\hline \multicolumn{11}{|c|}{ By area or country } \\
\hline \multicolumn{11}{|c|}{ Commercial liabilities } \\
\hline 47 & Europe...$\ldots \ldots$ & 9,030 & 10,574 & 10,962 & 14,876 & 15,069 & $15,330^{r}$ & $15,641^{r}$ & $17,781^{r}$ & 17,845 \\
\hline 48 & Belgium-Luxembourg & 123 & 109 & 222 & 209 & 220 & 260 & 280 & 377 & 537 \\
\hline 49 & France ............. & 1,019 & 1,870 & 1,567 & 1,559 & 1,667 & 1,712 & 1,774 & 1,688 & 2,047 \\
\hline 50 & Germany ........ & 1,024 & 1,113 & 1,217 & 2,201 & 2,161 & 2,037 & 1,284 & 1,359 & 1,317 \\
\hline 51 & Netherlands ..... & 305 & 489 & 526 & 755 & 929 & 938 & 751 & 1,133 & 730 \\
\hline 52 & Switzerland & 564 & 1,113 & 724 & 1,370 & 1,291 & 1,418 & $1,937^{r}$ & $2,743^{r}$ & 2,871 \\
\hline 53 & United Kingdom . & 3,407 & 2,882 & 3,046 & 4,313 & 3,928 & 3,328 & 3,730 & 4,425 & 3,696 \\
\hline & MEMO & & & & & & & & & \\
\hline 54 & Euro area ${ }^{3}$ & 3,730 & 5,405 & 5,226 & 6,850 & 7,279 & 7,677 & 7,162 & 7,114 & 8,344 \\
\hline 55 & Canada & 2,145 & 2,375 & 3,708 & 4,737 & 4,271 & 5,663 & 5,365 & 5,846 & 5,930 \\
\hline 56 & Latin America and Caribbean & 4,276 & 5,748 & 5,757 & 7,817 & 8,546 & 8,358 & 9.671 & $10.767^{r}$ & 8,508 \\
\hline 57 & 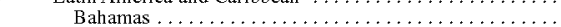 & 32 & 70 & 70 & 163 & 122 & 89 & 180 & 162 & 108 \\
\hline 58 & Bermuda . & 515 & 713 & 777 & 1,008 & 1,160 & 707 & 1,264 & 1,010 & 663 \\
\hline 59 & Brazil . & 113 & 218 & 241 & 360 & 425 & 911 & 1,142 & 1,049 & 1,070 \\
\hline 60 & British West Indies ${ }^{4}$ & n.a. & n.a. & n.a. & n.a. & n.a. & n.a. & n.a. & n.a. & n.a. \\
\hline 61 & Cayman Islands $\ldots \ldots \ldots \ldots \ldots \ldots \ldots \ldots \ldots \ldots$ & 101 & 76 & 539 & 647 & 728 & 1,167 & 997 & 859 & 747 \\
\hline 62 & Mexico ........ & 1,942 & 2,209 & 2,120 & 2,512 & 2,936 & 2,820 & 3,076 & $4,130^{r}$ & 2,554 \\
\hline 63 & Venezuela & 433 & 680 & 353 & 663 & 586 & 557 & 870 & 1,174 & 1,325 \\
\hline 64 & Asia & 12,239 & 17,427 & 18,755 & 24,049 & 26,832 & 23,410 & $30,462^{r}$ & 30,187 & 31,372 \\
\hline 65 & Japan & 4,221 & 5,971 & 5,864 & 5,688 & 5,476 & 5,325 & 6,166 & 5,564 & 5,888 \\
\hline 66 & Middle Eastern oil-exporting countries ${ }^{5} \ldots \ldots$ & 2,910 & 3,986 & 3,855 & 5,803 & 7,324 & 7,105 & 9,945 & 12,254 & 9,982 \\
\hline 67 & Africa & 947 & 916 & 849 & 1,267 & 1.453 & 1.458 & 2.141 & 1.920 & 1.587 \\
\hline 68 & Oil-exporting countries & 424 & 493 & 283 & 637 & 763 & 655 & 1,069 & 1,108 & 739 \\
\hline 69 & All other ${ }^{7}$ & 525 & 421 & 474 & 1,113 & 1,631 & 1,697 & 1,832 & 1,747 & 1,744 \\
\hline
\end{tabular}

1. Data available beginning March 2003. For data on borrowings and repurchase agreements, data available on a consistently defined basis beginning in June 2006

. Foreign currency detail available beginning March 2003

3. Comprises Austria, Belgium, Finland, France, Germany, Ireland, Italy, Luxembourg, Netherlands, Portugal, and Spain. As of December 2001, also includes Greece. Although Slovenia joined the euro area January 2007 , separate data for Slovenia are not available.

4. Beginning March 2003, data for the Cayman Islands replaced data for the British West

5. Comprises Bahrain, Iran, Kuwait, Oman, Qatar, Saudi Arabia, and United Arab Emirates (Trucial States)

6. Comprises Algeria, Gabon, Libya, and Nigeria.

7. Includes international and regional organizations. Indies. 
52 Federal Reserve Bulletin Statistical Supplement $\square$ December 2008

3.23 CLAIMS ON UNAFFILIATED FOREIGNERS Reported by Nonbanking Business Enterprises in the United States Millions of dollars, end of period

\begin{tabular}{|c|c|c|c|c|c|c|c|c|c|c|}
\hline \multirow{2}{*}{\multicolumn{2}{|c|}{ Type of claim, and area or country }} & \multirow{2}{*}{2004} & \multirow{2}{*}{2005} & \multirow{2}{*}{2006} & \multicolumn{3}{|c|}{2007} & \multicolumn{3}{|c|}{2008} \\
\hline & & & & & June & Sept. & Dec. & Mar. & June & Sept.P \\
\hline \multicolumn{2}{|c|}{1 Total } & 143,232 & 144,950 & 126,032 & 137,231 & 144,477 & $136,416^{\mathrm{r}}$ & $138,809^{r}$ & $146,367^{\mathrm{r}}$ & 118,962 \\
\hline \multicolumn{2}{|r|}{ By type } & & & & & & & & & \\
\hline \multicolumn{2}{|r|}{2 Financial claims } & 110,517 & 111,394 & 88,646 & 93,794 & 100,784 & 88,031 & 91,838 & 95,287 & 72,572 \\
\hline \multirow{2}{*}{\multicolumn{2}{|c|}{ 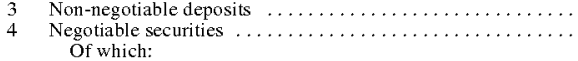 }} & 47,270 & 50,149 & 31,909 & 27,228 & 36,820 & 29,891 & 34,052 & 43,002 & 23,220 \\
\hline & & 9,892 & 13,180 & 2,744 & 2,223 & 1,344 & 1,245 & 1,354 & 1,387 & 950 \\
\hline \multirow{2}{*}{$\begin{array}{l}5 \\
6\end{array}$} & \multirow[b]{2}{*}{ 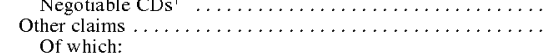 } & 103 & 65 & 15 & 20 & 14 & 31 & 28 & 37 & 49 \\
\hline & & 53,355 & 48,065 & 53,993 & 64,343 & 62,620 & 56,895 & 56,432 & 50,898 & 48,402 \\
\hline \multirow{2}{*}{$\begin{array}{l}7 \\
8\end{array}$} & \multirow{2}{*}{ 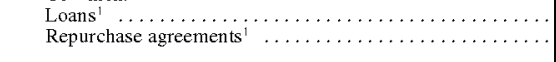 } & n.a. & na. & 10,057 & 14,268 & 14,678 & 12,875 & 13,083 & $10,911^{r}$ & 11,731 \\
\hline & & n.a. & n.a. & 17,842 & 18,789 & 17,506 & 10,765 & 8,814 & 7,196 & 5,836 \\
\hline \multirow{2}{*}{\multicolumn{2}{|c|}{ By currency }} & & & & & & & & & \\
\hline 9 & & 67,445 & 75,802 & 66,871 & 66,625 & 65,146 & 66,726 & 72,084 & 75,228 & 52,911 \\
\hline \multirow{2}{*}{\multicolumn{2}{|c|}{ 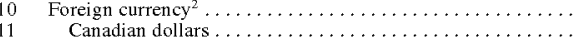 }} & 43,072 & 35,592 & 21,775 & 27,169 & 35,638 & 21,305 & 19,754 & 20,059 & 19,661 \\
\hline & & 1,329 & 9,348 & 8,454 & 3,729 & 4,387 & 4,583 & 4,692 & 4,512 & 5,122 \\
\hline \multicolumn{2}{|r|}{$\begin{array}{l}\text { Canadian dollars } \ldots \ldots \ldots \ldots \ldots \ldots \ldots \ldots \ldots \ldots \ldots \ldots \\
12 \ldots\end{array}$} & 20,651 & 9,308 & 5,843 & 15,339 & 15,498 & 8,717 & 7,791 & 8,535 & 6,967 \\
\hline \multirow{2}{*}{\multicolumn{2}{|c|}{ 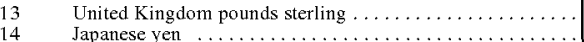 }} & 9,219 & 7,635 & 4,014 & 3,850 & 3,611 & 3,461 & 2,981 & 3,486 & 3,189 \\
\hline & & 7,345 & 3,537 & 746 & 868 & 9,113 & 1,059 & 886 & 908 & 973 \\
\hline & 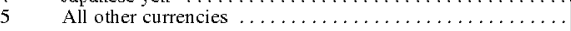 & 4,528 & 5,764 & 2,718 & 3,383 & 3,029 & 3,485 & 3,404 & 2,618 & 3,410 \\
\hline \multicolumn{2}{|r|}{ By area or country } & & & & & & & & & \\
\hline 16 & Europe $\ldots \ldots \ldots$ & 48,714 & 42,736 & 34,070 & 47,629 & 44,651 & 39,482 & 39,429 & 43,931 & 34,678 \\
\hline 17 & Belgium-Luxembourg & 2,177 & 1,743 & 328 & 2,985 & 2,270 & 1,393 & 3,856 & 2,951 & 3,252 \\
\hline 18 & 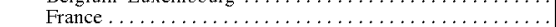 & 1,452 & 2,752 & 1,310 & 3,557 & 2,850 & 3,841 & 3,576 & 2,656 & 1,069 \\
\hline 19 & Germany ........... & 5,386 & 2,729 & 8,506 & 9,058 & 7,543 & 3,288 & 4,132 & 6,124 & 2,862 \\
\hline 20 & Netherlands & 7,389 & 3,033 & 2,842 & 5,138 & 3,690 & 3,005 & 2,142 & 3,592 & 2,343 \\
\hline 21 & Switzerland & 978 & 1,152 & 706 & 806 & 820 & 777 & 882 & 1,128 & 756 \\
\hline 22 & United Kingdom & 23,982 & 22,111 & 13,713 & 18,377 & 20,467 & 19,251 & 16,753 & 18,675 & 14,461 \\
\hline & MEMO: & & & & & & & & & \\
\hline 23 & Euro area ${ }^{3} \ldots$ & 22,053 & 16,702 & 17,002 & 25,150 & 20,564 & 16,020 & 18,374 & 21,581 & 16,356 \\
\hline 24 & Canada & 6,412 & 13,372 & 14,118 & 11,312 & 11,208 & 11,203 & 10,747 & 11,254 & 10,992 \\
\hline 25 & Latin America and Caribbean & 47,149 & 45,063 & 34,890 & 28,036 & 30,826 & 23,481 & 35,231 & 32,597 & 19,771 \\
\hline 26 & Bahamas .............. & 1,576 & 1,590 & 3,901 & 2,086 & 2,466 & 2,145 & 1,862 & 1,602 & 296 \\
\hline 27 & Bermuda . & 4,708 & 1,590 & 1,231 & 1,269 & 1,397 & 568 & 466 & 495 & 710 \\
\hline 28 & Brazil ... & 1,823 & 1,950 & 1,982 & 1,580 & 1,463 & 1,658 & 1,695 & 1,600 & 1,508 \\
\hline 29 & British West Indies ${ }^{4} \ldots \ldots \ldots \ldots \ldots \ldots$ & n.a. & n.a. & n.a. & n.a. & n.a. & n.a. & n.a. & n.a. & n.a. \\
\hline 30 & Cayman Islands $\ldots \ldots \ldots \ldots \ldots \ldots \ldots \ldots \ldots \ldots \ldots \ldots$ & 36,160 & 36,355 & 25,728 & 20,747 & 23,035 & 16,492 & 28,028 & 26,103 & 14,633 \\
\hline 31 & Mexico. & 1,738 & 2,019 & 1,175 & 1,166 & 1.217 & 1,222 & 1,232 & 1,419 & 1.267 \\
\hline 32 & Venezuela & 155 & 159 & 102 & 158 & 150 & 194 & 195 & 170 & 177 \\
\hline 33 & Asia & 6,840 & 7,223 & 3,238 & 4,745 & 11,738 & 11,533 & 3,831 & 4,525 & 3,616 \\
\hline 34 & Japan & 993 & 568 & 882 & 1,465 & 1,395 & 1,536 & 1,352 & 1,296 & 1,097 \\
\hline 35 & Middle Eastern oil-exporting countries ${ }^{5}$ & 137 & 242 & 60 & 1,111 & 111 & 150 & 148 & 166 & 179 \\
\hline 36 & Africa $\ldots \ldots \ldots \ldots$ & 306 & 1,291 & 345 & 366 & 368 & 425 & 455 & 520 & 529 \\
\hline 37 & Oil-exporting countries & 8 & 37 & 34 & 33 & 32 & 36 & 36 & 55 & 66 \\
\hline 38 & All other ${ }^{7} \ldots$. & 1,096 & 1,709 & 1,985 & 1,706 & 1,993 & 1,907 & 2,145 & 2,460 & 2,986 \\
\hline
\end{tabular}


3.23 CLAIMS ON UNAFFILIATED FOREIGNERS Reported by Nonbanking Business Enterprises in the United States-Continued Millions of dollars, end of period

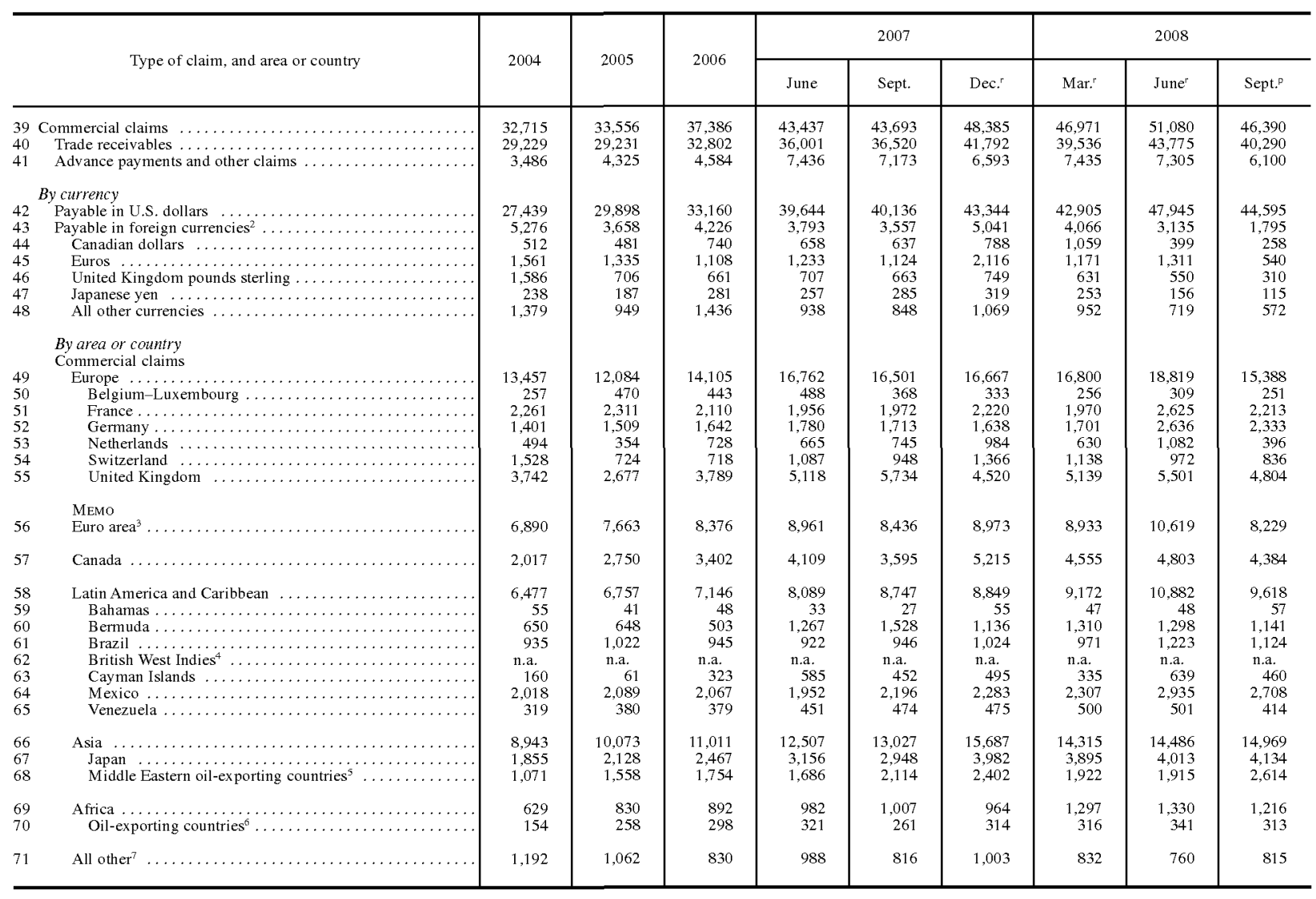

1. Data available beginning March 2003. For data on loans and repurchase agreements, data available on a consistently defined basis beginning in June 2006

2. Foreign currency detail available beginning March 2003 .
3. Comprises Austria, Belgium, Finland, France, Germany, Ireland, Italy, Luxembourg, Netherlands, Portugal, and Spain. As of December 2001, also includes Greece. Although Slovenia joined the euro area January 2007, separate data for Slovenia are not available.

(he British West

5. Comprises Bahrain, Iran, Kuwait, Oman, Qatar, Saudi Arabia, and United Arab Fmirates (Trucial States)

6. Comprises Algeria, Gabon, Libya, and Nigeria.

7. Includes international and regional organizations. Indies. 


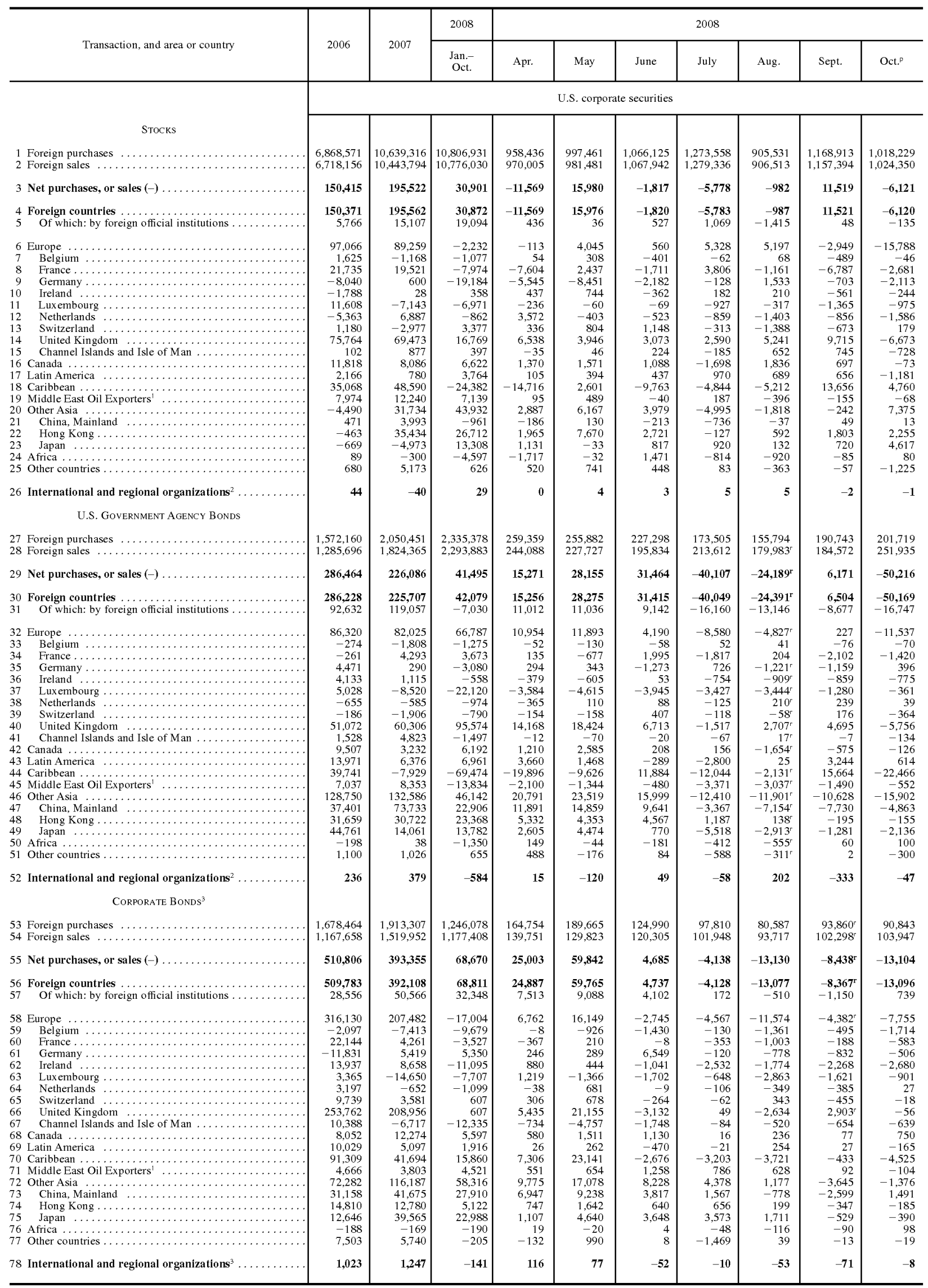


3.24 FOREIGN TRANSACTIONS IN SECURITIES—Continued

Millions of dollars

\begin{tabular}{|c|c|c|c|c|c|c|c|c|c|c|}
\hline \multirow{2}{*}{ Transaction, and area or country } & \multirow{2}{*}{2006} & \multirow{2}{*}{2007} & 2008 & \multicolumn{7}{|c|}{2008} \\
\hline & & & Jan.-- & Apr. & May & June & July & Aug. & Sept. & Oct. $^{p}$ \\
\hline & \multicolumn{10}{|c|}{ Foreign securities } \\
\hline 79 Stocks, net purchases or sales $(-)^{4}$ & $1064=5$ & $0=200$ & 1275 & & & & & & & \\
\hline 80 Foreign purchases & $\begin{array}{l}-106,455 \\
3,636,185\end{array}$ & $\begin{array}{r}-93,298 \\
5,215,765\end{array}$ & $\begin{array}{r}-1,225 \\
4,884,940\end{array}$ & $\begin{array}{r}-245 \\
505,496\end{array}$ & $\begin{array}{r}-18,106 \\
494,660\end{array}$ & $\begin{array}{r}1,562 \\
499,993\end{array}$ & $\begin{array}{r}16,894 \\
560,901\end{array}$ & $\begin{array}{r}2,851 \\
428,218\end{array}$ & $\begin{array}{r}-2,445 \\
482,941\end{array}$ & $\begin{array}{r}21,795 \\
458,842\end{array}$ \\
\hline 81 Foreign sales .... & $3,742,640$ & $5,311,063$ & $4,886,165$ & 505,741 & 512,766 & 498,431 & 544,007 & 425,367 & 485,386 & 437,047 \\
\hline 82 Bonds, net purchases or sales $(-)^{4}$ & $-144,452$ & $-129,015$ & 72,126 & 10,728 & $-8,303$ & $-11,517$ & 17,278 & $17,366^{\mathrm{r}}$ & 37,810 & 14,513 \\
\hline 83 Foreign purchases & $1,879,713$ & $2,971,803$ & $2,037,257$ & 193,225 & 182,056 & 188,259 & 158,503 & 157,238 & 227,068 & 177,088 \\
\hline 84 Foreign sales $\ldots$. & $2,024,165$ & $3,100,818$ & $1,965,131$ & 182,497 & 190,359 & 199,776 & 141,225 & 139,872 & 189,258 & 162,575 \\
\hline 85 Net purchases, or sales (-) of stocks and bonds ${ }^{4}$. & $-250,907$ & $-224,313$ & 70,901 & 10,483 & $-26,409$ & $-9,955$ & 34,172 & $20,217^{\mathrm{r}}$ & 35,365 & 36,308 \\
\hline 86 Foreign countries & $-256,016$ & $-240,242$ & 61,457 & 8,529 & $-26,401$ & $-9,858$ & 34,158 & $17,750^{\mathrm{r}}$ & 34,415 & 35,930 \\
\hline 87 Europe & $-220,413$ & $-218,683$ & 38,957 & $-5,690$ & $-18,064$ & 812 & 12,103 & $23,181^{r}$ & 33,673 & 24,674 \\
\hline 88 Euro Area ${ }^{5}$ & $-54,927$ & $-62,543$ & 22,522 & $-3,927$ & $-1,544$ & $-1,739$ & 17,610 & 8,768 & 14,325 & -210 \\
\hline 89 United Kingdom & $-157,698$ & $-154,906$ & $-7,202$ & $-6,145$ & $-19,134$ & -856 & $-2,470$ & 11,140 & 8,655 & 19,993 \\
\hline 90 Canada ..... & $-18,153$ & $-10,935$ & $-5,108$ & $-2,397$ & $-6,351$ & $-2,216$ & 1,444 & 1,734 & 2,317 & $-1,677$ \\
\hline 91 Latin America & $-12,714$ & $-7,948$ & 17,608 & 2,899 & $-5,117$ & 3,603 & 477 & $-1,133$ & 1,019 & 3,832 \\
\hline 92 Caribbean .... & 25,656 & $-18,442$ & $-38,107$ & 4,420 & $-2,136$ & $-7,296$ & 2,253 & $-13,624$ & $-8,625$ & 407 \\
\hline 93 Asia ........ & $-18,652$ & 27,066 & 67,550 & 10,532 & 7,726 & 3,663 & 16,754 & $5,977^{\circ}$ & 2,861 & 6,114 \\
\hline 94 Japan & 2,159 & 4,032 & 11,830 & $-1,188$ & 5,233 & $-1,658$ & 8,144 & 591 & $-1,116$ & $-1,185$ \\
\hline 95 Africa. & $-2,252$ & 1,112 & 1,264 & -217 & -591 & -22 & 296 & 601 & 185 & 697 \\
\hline 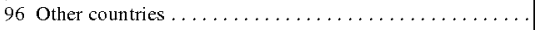 & $-9,488$ & $-12,412$ & $-20,707$ & $-1,018$ & $-1,868$ & $-8,402$ & 831 & 1,014 & 2,985 & 1,883 \\
\hline $\begin{array}{c}97 \begin{array}{c}\text { Nonmonetary international and } \\
\text { regional organizations } \\
2\end{array} \text {. }\end{array}$ & 5,109 & 15,929 & 9,444 & 1,954 & -8 & -97 & 14 & 2,467 & 950 & 378 \\
\hline
\end{tabular}

1. Comprises oil-exporting countries as follows: Bahrain, Iran, Iraq, Kuwait, Oman, Qatar, Saudi Arabia, and United Arab Emirates (Trucial States).

2. Includes the International Bank for Reconstruction and Development, as well as African, Asian, Caribbean, European, Latin American, and Middle Eastern regional organizations. Beginning with data for June 2006, also includes the Bank for International Settle-

3. Includes state and local securities. Also includes issues of new debt securities sold abroad by U.S. corporations organized to finance direct investment abroad.

4. Net foreign sales (-) of foreign securities are equivalent to net U.S. purchases of foreign

5. Comprises Austria, Belgium, Finland, France, Germany, Ireland, Italy, Luxembourg, Netherlands, Portugal, and Spain. As of December 2001, also includes Greece.

\subsection{MARKETABLE U.S. TREASURY BONDS AND NOTES Foreign Transactions}

Millions of dollars; net purchases, or sales $(-)$, during period

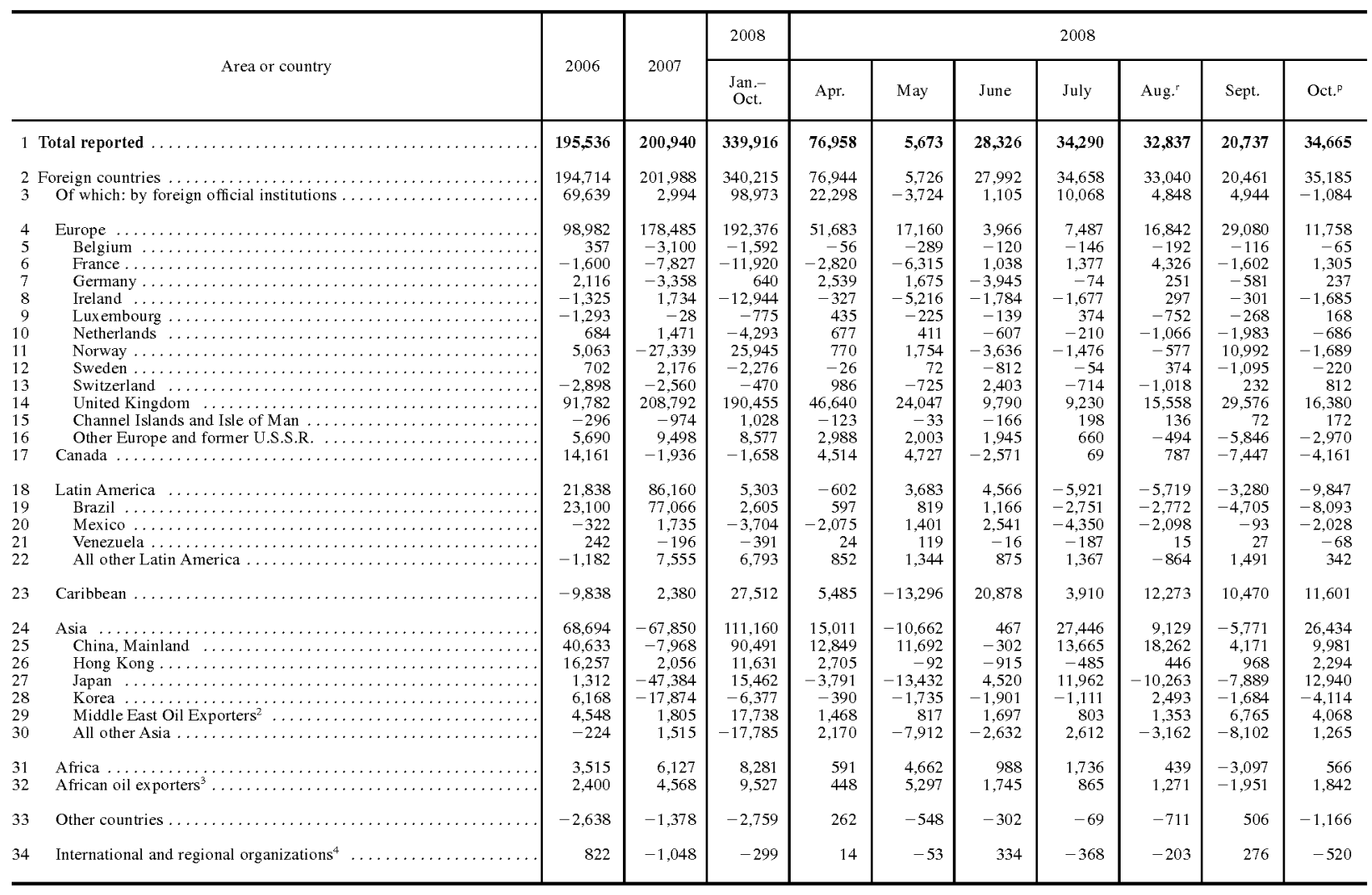

1. Official and private transactions in marketable U.S. Treasury securities having an original maturity of more than one year. Data are based on monthly transactions reports. Excludes nonmarketable U.S. Treasury bonds and notes held by official institutions of foreign countries.

2. Comprises Bahrain, Iran, Iraq, Kuwait, Oman, Qatar, Saudi Arabia, and United Arab

3. Comprises Algeria, Gabon, Libya, and Nigeria

4. Includes the International Bank for Reconstruction and Development, as well as African, Asian, Caribbean, European, Latin American, and Middle Eastern regional organizations. Beginning with data for June 2006, also includes the Bank for International Settlements. 
56 Federal Reserve Bulletin Statistical Supplement $\square$ December 2008

3.28 FOREIGN EXCHANGE RATES AND INDEXES OF THE FOREIGN EXCHANGE VALUE OF THE U.S. DOLLAR'

Currency units per U.S. dollar except as noted

\begin{tabular}{|c|c|c|c|c|c|c|c|c|c|}
\hline \multirow{2}{*}{ Item } & \multirow{2}{*}{2005} & \multirow{2}{*}{2006} & \multirow{2}{*}{2007} & \multicolumn{6}{|c|}{2008} \\
\hline & & & & May & June & July & Aug. & Sept. & Oct. \\
\hline & & & & & Exchange rate & & & & \\
\hline \multicolumn{10}{|l|}{ CoUntry/CURRENCY UnIT } \\
\hline 1 Australia/dollar ${ }^{2}$ & 0.7627 & 0.7535 & 0.8391 & 0.9492 & 0.9511 & 0.9620 & 0.8815 & 0.8168 & 0.6870 \\
\hline $2 \mathrm{Brazil} / \mathrm{real} . . . .$. & 2.4352 & 2.1738 & 1.9461 & 1.6585 & 1.6179 & 1.5900 & 1.6127 & 1.8031 & 2.1810 \\
\hline 3 Canada/dollar ... & 1.2115 & 1.1340 & 1.0734 & 0.9993 & 1.0166 & 1.0130 & 1.0535 & 1.0582 & 1.1847 \\
\hline 4 China, P.R./yuan & 8.1936 & 7.9723 & 7.6058 & 6.9725 & 6.8993 & 6.8355 & 6.8462 & 6.8307 & 6.8358 \\
\hline 5 Denmark/krone & 5.9953 & 5.9422 & 5.4413 & 4.7963 & 4.7926 & 4.7335 & 4.9894 & 5.2020 & 5.6253 \\
\hline 6 European Monetary Union/euro ${ }^{3}$ & 1.2449 & 1.2563 & 1.3711 & 1.5554 & 1.5562 & 1.5759 & 1.4955 & 1.4342 & 1.3266 \\
\hline 7 Hong Kong/dollar $\ldots \ldots \ldots \ldots \ldots \ldots$ & 7.7775 & 7.7681 & 7.8016 & 7.7988 & 7.8073 & 7.8001 & 7.8076 & 7.7854 & 7.7588 \\
\hline 8 India/rupee $\ldots \ldots \ldots \ldots \ldots$ & 44.00 & 45.19 & 41.18 & 42.00 & 42.76 & 42.70 & 42.91 & 45.53 & 48.62 \\
\hline 9 Japan/yen ........ & 110.11 & 116.31 & 117.76 & 104.36 & 106.92 & 106.85 & 109.36 & 106.57 & 99.97 \\
\hline 10 Malaysia/ringgit. & 3.7869 & 3.6661 & 3.4354 & 3.2127 & 3.2568 & 3.2476 & 3.3300 & 3.4405 & 3.5222 \\
\hline 11 Mexicolpeso.... & 10.894 & 10.906 & 10.928 & 10.438 & 10.327 & 10.209 & 10.115 & 10.663 & 12.659 \\
\hline 12 New Zealand/dollar ${ }^{2}$ & 0.7049 & 0.6492 & 0.7365 & 0.7777 & 0.7616 & 0.7546 & 0.7091 & 0.6739 & 0.6077 \\
\hline 13 Norway/krone .... & 6.4412 & 6.4095 & 5.8557 & 5.0571 & 5.1351 & 5.1058 & 5.3331 & 5.6958 & 6.4973 \\
\hline 14 Singapore $/$ dollar $\ldots \ldots \ldots \ldots \ldots \ldots \ldots \ldots$ & 1.6639 & 1.5882 & 1.5065 & 1.3659 & 1.3679 & 1.3591 & 1.4052 & 1.4297 & 1.4784 \\
\hline 15 South Africa/rand & 6.3606 & 6.7668 & 7.0477 & 7.6076 & 7.9367 & 7.6114 & 7.6651 & 8.0753 & 9.7800 \\
\hline 16 South Korea/won & $1,023.75$ & 954.32 & 928.97 & $1,034.13$ & $1,031.49$ & $1,015.05$ & $1,046.11$ & $1,134.87$ & $1,329.19$ \\
\hline 17 Sri Lanka/rupee . & 100.383 & 103.940 & 110.620 & 107.771 & 107.763 & 107.609 & 107.718 & 107.823 & 108.166 \\
\hline 18 Sweden/krona. . & 7.4710 & 7.3718 & 6.7550 & 5.9887 & 6.0249 & 6.0015 & 6.2845 & 6.6816 & 7.4435 \\
\hline 19 Switzerland/franc & 1.2459 & 1.2532 & 1.1999 & 1.0448 & 1.0371 & 1.0283 & 1.0841 & 1.1102 & 1.1429 \\
\hline 20 Taiwan/dollar ... & 32.131 & 32.507 & 32.855 & 30.589 & 30.371 & 30.414 & 31.221 & 31.992 & 32.703 \\
\hline 21 Thailand/baht . & 40.252 & 37.876 & 32.203 & 32.026 & 33.175 & 33.471 & 33.820 & 34.238 & 34.421 \\
\hline 22 United Kingdom/pound ${ }^{2} \ldots \ldots \ldots \ldots \ldots \ldots$ & 1.8204 & 1.8434 & 2.0020 & 1.9650 & 1.9664 & 1.9888 & 1.8865 & 1.7973 & 1.6862 \\
\hline \multirow[t]{2}{*}{ 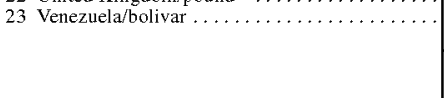 } & & & & & & 2.14 & & 2.14 & \\
\hline & \multicolumn{9}{|c|}{ Indexes ${ }^{4}$} \\
\hline \multicolumn{10}{|l|}{ NOMINAL } \\
\hline 25 Major currencies (March 1973=100) ( $^{6} \ldots$ & 83.71 & 82.46 & 77.84 & 70.75 & 71.42 & 70.91 & 74.09 & 75.51 & 80.42 \\
\hline $\begin{array}{l}26 \text { Other important trading partners (January } \\
\qquad 1997=100)^{7} \ldots \ldots \ldots \ldots \ldots \ldots \ldots\end{array}$ & 138.89 & 135.38 & 130.28 & 123.33 & 122.78 & 121.89 & 122.94 & 126.53 & 135.09 \\
\hline \multicolumn{10}{|l|}{ REAL } \\
\hline 27 Broad (March 1973=100) $\ldots \ldots$. . & 97.98 & 96.87 & $92.28^{r}$ & 85.94 & $86.55^{r}$ & $85.98^{r}$ & $87.88^{r}$ & $89.73^{r}$ & 94.57 \\
\hline 28 Major currencies (March 1973=100) ${ }^{6}$ & 90.63 & 90.55 & $86.40^{\mathrm{r}}$ & 79.99 & $81.06^{r}$ & $80.66^{r}$ & $83.87^{r}$ & 85.26 & 90.07 \\
\hline $\begin{array}{l}29 \text { Other important trading partners (March } \\
\qquad 1973=100)^{7} \ldots \ldots \ldots \ldots \ldots \ldots \ldots \ldots\end{array}$ & 117.40 & 114.69 & 109.06 & 102.18 & 102.26 & 101.43 & $101.90^{\mathrm{r}}$ & 104.51 & 109.87 \\
\hline
\end{tabular}

1. Averages of certified noon buying rates in New York for cable transfers. Data in this table also appear in the Board's G.5 (405) monthly statistical release, available at www.federalreserve.gov/releases.

2. U.S. dollars per currency unit.

3. The euro is reported in place of the individual euro area currencies. By convention, the rate is reported in U.S. dollars per euro.

4. Starting with the January 2004 Statistical Supplement to the Federal Reserve Bulletin, revised index values resulting from the periodic revision of data that underlie the calculated trade weights are reported. For more information on the indexes of the foreign exchange yalue of the dollar, see Federal Reserve Bulletin, vol. 91 (Winter 2005), pp. 1-8.

5. Weighted average of the foreign exchange value of the U.S. dollar against the currencies of a broad group of U.S trading partners. The weight for each currency is computed as an average of U.S. bilateral import shares from and export shares to the issuing country and of a

measure of the importance to U.S. exporters of that country's trade in third country markets. The source for exchange rates not listed in the table above but used in the calculation of this index is Bloomberg LLP.

6. Weighted average of the foreign exchange value of the U.S. dollar against a subset of broad index currencies that circulate widely outside the country of issue. The weight for each currency is its broad index weight scaled so that the weights of the subset of currencies in the index sum to one.

7. Weighted average of the foreign exchange value of the U.S. dollar against a subset of broad index currencies that do not circulate widely outside the country of issue. The weight for each currency is its broad index weight scaled so that the weights of the subset of currencies in the index sum to one. The source for exchange rates not listed in the table above but used in the calculation of this index is Bloomberg LLP. 


\section{Guide to Special Tables}

\section{SPECIAL TABLES—Data Published Irregularly, with Latest Bulletin or Supplement Reference}

Title, Table Number, and Reporting Date for Data

Assets and liabilities of commercial banks, 4.20

December 31, 2007

March 31, 2008

June 30,2008

September 30, 2008

Terms of lending at commercial banks, 4.23

November 2007

February 2008

May 2008 ...

August 2008

Assets and liabilities of U.S. branches and agencies of foreign banks, 4.30

September 30, 2007

December 31, 2007

March 31, 2008

June 30, 2008

Pro forma financial statements for Federal Reserve priced services, 4.31 *

March 31, 2001

June 30, $2001 \ldots$

September 30, 2001

Residential lending reported under the Home Mortgage Disclosure Act, 4.34-4.411

1989-2001

1990-2002

1991-2003

Disposition of applications for private mortgage insurance, $4.42-4.45$

1998-2001

1999-2002

2000-2003

Small loans to businesses and farms, 4.46-4.48

1997-2003 ....

1998-2004

1999-2005

2000-2006

2001-2007

Community development lending reported under the Community Reinvestment Act, 4.49

2003

2004

2005

2006

2007
Issue Page Reference

$\begin{array}{rrr}\text { March 2008 } & 58 & \text { Supplement } \\ \text { June 2008 } & 58 & \text { Supplement } \\ \text { September 2008 } & 58 & \text { Supplement } \\ \text { December 2008 } & 58 & \text { Supplement }\end{array}$

February 2008

May 2008

August 2008

November 2008

58 Supplement

58 Supplement

58 Supplement

58 Supplement

February 2008

May 2008

August 2008

November 2008

64 Supplement

64 Supplement

64 Supplement

64 Supplement

$\begin{array}{rll}\text { August 2001 } & \text { A76 } & \text { Bulletin } \\ \text { October 2001 } & \text { A64 } & \text { Bulletin } \\ \text { January 2002 } & \text { A64 } & \text { Bulletin }\end{array}$

September 2002

September 2003

September 2004

A58 Bulletin

A58 Bulletin

58 Supplement

September 2002

September 2003

September 2004

A67 Bulletin

A67 Bulletin

67 Supplement

September 2004

70 Supplement

60 Supplement

September 2005

September 2006

September 2007

60 Supplement

60 Supplement

September 2008

60 Supplement

September $2004 \quad 73 \quad$ Supplement September $2005 \quad 63$ Supplement

September $2006 \quad 63$ Supplement

September $2007 \quad 63$ Supplement

September $2008 \quad 63$ Supplement

*The pro forma financial statements for Federal Reserve priced services are no longer published in the Bulletin after the January 2002 issue. The statements are in the Board's yearly Annual Report to the Congress (www.federalreserve.gov/boarddocs/rptcongress). 
4.20 DOMESTIC AND FOREIGN OFFICES Insured Commercial Bank Assets and Liabilities

Consolidated Report of Condition, September 30, 2008

Millions of dollars except as noted

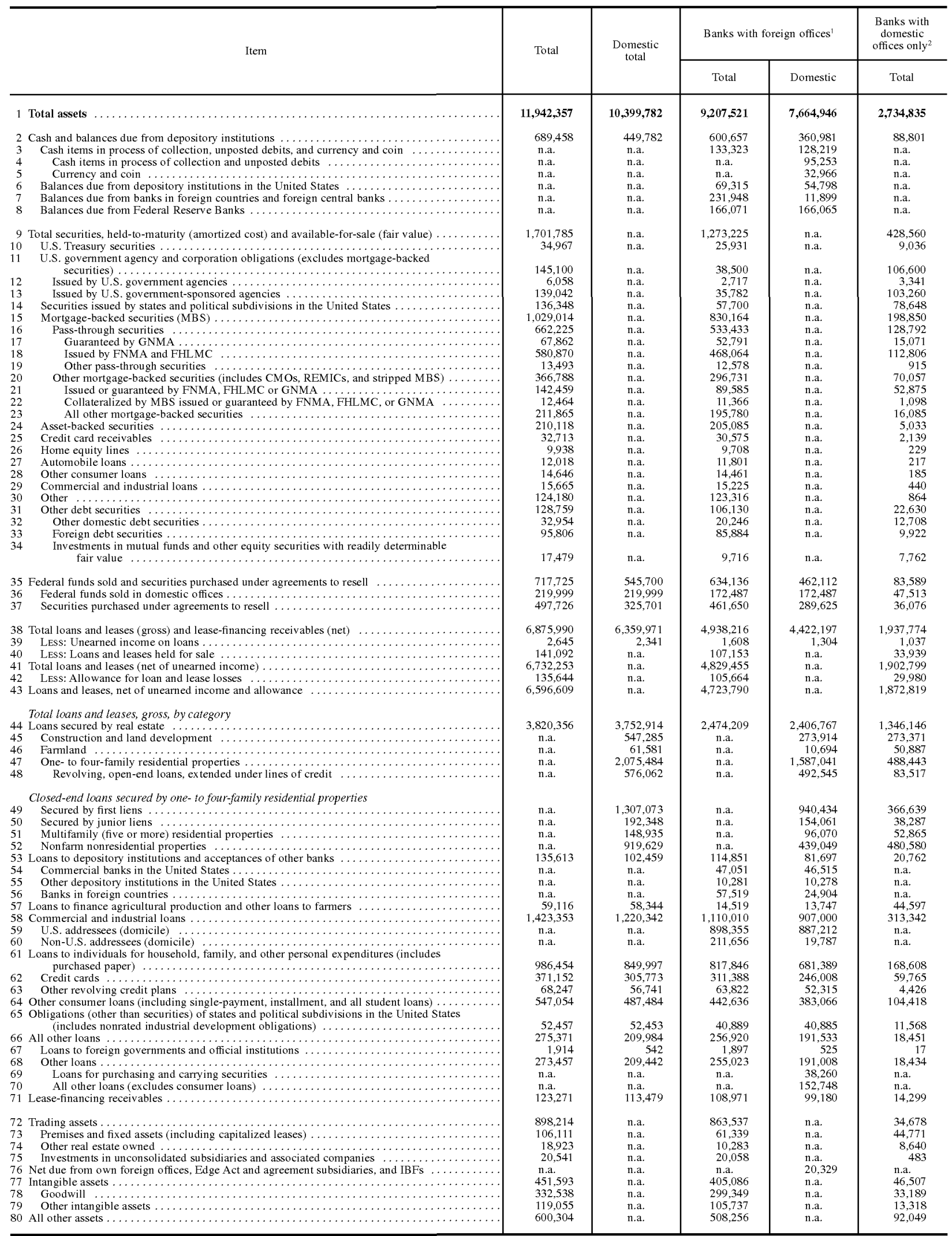


4.20 DOMESTIC AND FOREIGN OFFICES Insured Commercial Bank Assets and Liabilities-Continued

Consolidated Report of Condition, September 30, 2008

Millions of dollars except as noted

\begin{tabular}{|c|c|c|c|c|c|c|}
\hline & \multirow{2}{*}{ Item } & \multirow{2}{*}{ Total } & \multirow{2}{*}{$\begin{array}{l}\text { Domestic } \\
\text { total }\end{array}$} & \multicolumn{2}{|c|}{ Banks with foreign offices ${ }^{1}$} & \multirow{2}{*}{$\frac{\begin{array}{c}\text { Banks with } \\
\text { domestic } \\
\text { offices only }\end{array}}{\text { Total }}$} \\
\hline & & & & Total & Domestic & \\
\hline 81 & Total liabilities, minority interest, and equity capital & $11,942,357$ & n.a. & $9,207,521$ & n.a. & $2,734,835$ \\
\hline 82 & Total liabilities & $10,770,631$ & $9,228,560$ & $8,325,182$ & $6,783,111$ & $2,445,449$ \\
\hline 83 & Total deposits & $7,711,597$ & $6,206,866$ & $5,720,624$ & $4,215,893$ & $1,990,973$ \\
\hline 84 & Individuals, partnerships, and corporations (include all certified and official checks) & $6,961,043$ & $5,773,293$ & $5,135,445$ & $3,947,695$ & $1,825,598$ \\
\hline 85 & 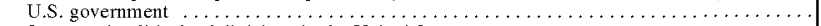 & n.a. & 5,180 & n.a. & 4,338 & 843 \\
\hline 86 & States and political subdivisions in the United States. & n.a. & 318,059 & n.a. & 183,161 & 134,898 \\
\hline 87 & Commercial banks and other depository institutions in the United States & 149,428 & 82,325 & 119,971 & 52,868 & 29,457 \\
\hline 88 & 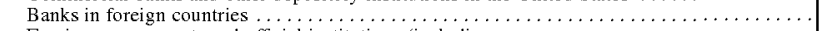 & 176,866 & 22,710 & 176,695 & 22,539 & 171 \\
\hline & $\begin{array}{l}\text { Foreign governments and official institutions (including } \\
\text { foreign central banks) } \ldots \ldots \ldots \ldots \ldots \ldots \ldots \ldots \ldots\end{array}$ & 100,415 & 5,300 & 100,407 & 5,292 & 8 \\
\hline 90 & Total transaction accounts & n.a. & 722,104 & n.a. & 449,553 & 272,551 \\
\hline 91 & Individuals, partnerships, and corporations (include all certified and official checks) & n.a. & 607,499 & n.a. & 373,120 & 234,379 \\
\hline 92 & 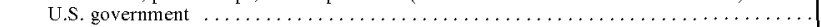 & n.a. & 2,330 & n.a. & 1,988 & 342 \\
\hline 93 & States and political subdivisions in the United States... & n.a. & 69,813 & n.a. & 36,602 & 33,211 \\
\hline 94 & Commercial banks and other depository institutions in the United States .. & n.a. & 33,313 & n.a. & 28,781 & 4,532 \\
\hline 95 & 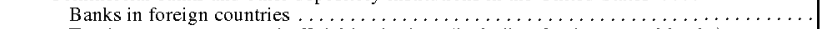 & n.a. & 8,357 & n.a. & 8,274 & 83 \\
\hline 96 & Foreign governments and official institutions (including foreign central banks) . & n.a. & 792 & n.a. & 788 & 4 \\
\hline 97 & Total demand deposits & n.a. & 540,862 & n.a. & 374,609 & 166,253 \\
\hline 98 & Total nontransaction accounts & n.a. & $5,484,762$ & n.a. & $3,766,340$ & $1,718,422$ \\
\hline 99 & Individuals, partnerships, and corporations (include all certified and official checks) & n.a. & $5,165,794$ & n.a. & $3,574,575$ & $1,591,219$ \\
\hline 100 & 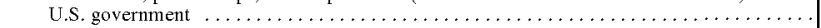 & n.a. & 2,850 & n.a. & 2,350 & 500 \\
\hline 101 & States and political subdivisions in the United States & n.a. & 248,246 & n.a. & 146,559 & 101,686 \\
\hline 102 & Commercial banks and other depository institutions in the United States & n.a. & 49,012 & n.a. & 24,088 & 24,925 \\
\hline 103 & 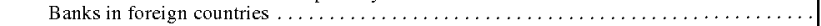 & n.a. & 14,352 & n.a. & 14,265 & 88 \\
\hline 104 & Foreign governments and official institutions (including foreign central banks) & n.a. & 4,507 & n.a. & 4,504 & 4 \\
\hline 105 & Federal funds purchased and securities sold under agreements to repurchase . & 855,954 & 694,929 & 711,307 & 550,282 & 144,647 \\
\hline 106 & Federal funds purchased in domestic offices $\ldots \ldots \ldots \ldots \ldots \ldots \ldots \ldots$ & 298,839 & 298,839 & 215,581 & 215,581 & 83,259 \\
\hline 107 & Securities sold under agreements to repurchase & 557,114 & 396,090 & 495,726 & 334,702 & 61,388 \\
\hline 108 & Trading liabilities $\ldots \ldots \ldots \ldots \ldots \ldots \ldots \ldots$ & 356,666 & n.a. & 356,127 & n.a. & 539 \\
\hline 109 & Other borrowed money (includes mortgage indebtedness and obligations under capitalized & & & & & \\
\hline & 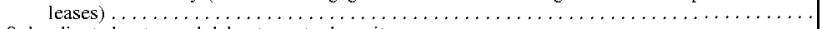 & $1,328,263$ & $1,206,938$ & $1,061,882$ & 940,557 & 266,380 \\
\hline 110 & Subordinated notes and debentures to deposits. & 173,781 & n.a. & 165,577 & n.a. & 8,204 \\
\hline 111 & Net due to own foreign offices, Edge Act and agreement subsidiaries, and IBFs . . . . . & n.a. & n.a. & n.a. & 532,970 & n.a. \\
\hline 112 & 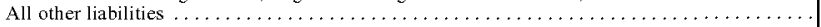 & 344,371 & n.a. & 309,666 & n.a. & 34,705 \\
\hline 113 & Minority interest in consolidated subsidiaries. & 15,744 & n.a. & 14,628 & n.a. & 1,115 \\
\hline 114 & Total equity capital & $1,155,982$ & n.a. & 867,711 & n.a. & 288,271 \\
\hline & МЕмо & & & & & \\
\hline 115 & Trading assets at large banks ${ }^{2}$ & 848,183 & 454,184 & 813,573 & 419,574 & 34,610 \\
\hline 116 & U.S. Treasury securities (domestic offices) & n.a. & 36,958 & na. & 36,863 & 95 \\
\hline 117 & U.S. government agency obligations (excluding MBS) & n.a. & 8,019 & n.a. & 6,855 & 1,164 \\
\hline 118 & Securities issued by states and political subdivisions in the United States... & n.a. & 27,426 & n.a. & 27,340 & 85 \\
\hline 119 & 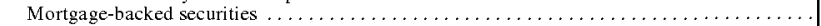 & n.a. & 79,436 & n.a. & 75,425 & 4,011 \\
\hline 120 & 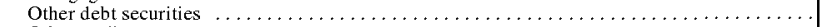 & n.a. & 80,768 & n.a. & 55,541 & 25,227 \\
\hline 121 & 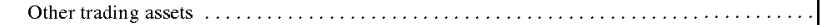 & n.a. & 28,418 & n.a. & 25,629 & 2,789 \\
\hline 122 & Trading assets in foreign offices $\ldots \ldots \ldots \ldots \ldots \ldots \ldots$ & 273,930 & 0 & 273,930 & 0 & 0 \\
\hline 123 & Revaluation gains on interest rate, foreign exchange rate, and other & & & & & \\
\hline & commodity and equity contracts $\ldots \ldots \ldots \ldots \ldots \ldots \ldots$ & 313,228 & 193,159 & 311,990 & 191,920 & 1,239 \\
\hline 124 & Total individual retirement (IRA) and Keogh plan accounts & n.a. & 229,487 & n.a. & 125,144 & 104,343 \\
\hline 125 & Total brokered deposits $\ldots \ldots \ldots \ldots \ldots \ldots \ldots \ldots \ldots$ & n.a. & 526,129 & n.a. & 255,915 & 270,214 \\
\hline 126 & Fully insured brokered deposits & n.a. & 384,024 & n.a. & 154,082 & 229,941 \\
\hline 127 & Issued in denominations of less than $\$ 100,000 \ldots \ldots \ldots$ & n.a. & 329,715 & n.a. & 135,865 & 193,850 \\
\hline 128 & Issued in denominations of $\$ 100,000$, or in denominations greater than $\$ 100,000$ and & & & & & \\
\hline & participated out by the broker in shares of $\$ 100,000$ or less. & n.a. & 54,308 & n.a. & 18,217 & $\begin{array}{r}36,091 \\
576\end{array}$ \\
\hline 129 & Money market deposit accounts (MMDAs) & n.a. & $2,471,453$ & n.a. & $1,895,188$ & 576,266 \\
\hline 130 & Other savings deposits (excluding MMDAs) & n.a. & 706,606 & n.a. & 463,123 & 243,482 \\
\hline 131 & Total time deposits of less than $\$ 100,000 \ldots$ & n.a. & $1,179,200$ & n.a. & 625,075 & 554,125 \\
\hline 132 & Total time deposits of $\$ 100,000$ or more .. & n.a. & $1,127,502$ & n.a. & 782,954 & 344,549 \\
\hline 133 & Number of banks & 7,116 & 7,116 & 113 & n.a. & 7,003 \\
\hline
\end{tabular}

NoTE. The notation "n.a." indicates the lesser detail available from banks that do not have foreign offices, the inapplicability of certain items to banks that have only domestic offices, or the absence of detail on a fully consolidated basis for banks that have foreign offices.

1. All transactions between domestic and foreign offices of a bank are reported in "net due from" and "net due to" lines. All other lines represent transactions with parties other than the from" and "net due to" "ines. All other lines represent transactions with parties other than the by contc and foreign offices of each bank. Because these intra-office transactions are nullified by consolidation, total assets and total liabilities for the entire bank $\mathrm{m}$ ay
Foreign offices include branches in foreign countries, Puerto Rico, and U.S.-affiliated insular areas; subsidiaries in foreign countries; all offices of Edge Act and agreement corporations wherever located; and international banking facility (IBF).

2 . Components of "Trading Assets at Large Banks" are reported only by banks that reported trading assets of $\$ 2$ million or more any quarter of the preceding calendar year. 


\section{Index to Statistical Tables}

ACCEPTANCES, bankers (See Bankers acceptances)

Assets and liabilities (See also Foreigners)

Commercial banks, $15-21,58-59$

Domestic finance companies, 30, 31

Federal Reserve Banks, 10

Foreign-related institutions, 20

Automobiles

Consumer credit, 34

Production, 42,43

BANKERS acceptances, 5, 10

Bankers balances, 15-21 (See also Foreigners)

Bonds (See also U.S. government securities)

New issues, 29

Rates, 23

Business loans (See Commercial and industrial loans)

CAPACITY utilization, 40, 41

Capital accounts

Commercial banks, 15-21, 58-59

Federal Reserve Banks, 10

Certificates of deposit, 23

Commercial and industrial loans

Commercial banks, 15-21, 58-59

Weekly reporting by banks, 17, 18

Commercial banks

Assets and liabilities, 15-21, 58-59

Commercial and industrial loans, 15-21, 58-59

Consumer loans held, by type and terms, 34

Real estate mortgages held, by holder and property, 33

Time and savings deposits, 4

Commercial paper, 22, 23, 30

Condition statements (See Assets and liabilities)

Consumer credit, 34

Corporations

Security issues, 29,55

Credit unions, 34

Currency in circulation, 5, 13

Customer credit, stock market, 24

DEBT (See securities and U.S. government securities)

Demand deposits, 15-21

Depository institutions

Reserve requirements, 8

Reserves and related items, 4-6, 12

Deposits

Commercial banks, 4, 15-21, 58-59

Federal Reserve Banks, 5, 10

Discount rates at Reserve Banks and at foreign central banks and foreign countries (See Interest rates)

Discounts and advances by Reserve Banks (See Loans)

EXCHANGE rates, foreign, 56

FARM mortgage loans, 33

Federal agency obligations, 5, 9-11, 26, 27

Federal credit agencies, 28

Federal finance

Debt subject to statutory limitation, and types and ownership of gross debt, 25

Federal Financing Bank, 28

Federal funds, 23

Federal Home Loan Banks, 28

Federal Home Loan Mortgage Corporation, 28, 32, 33

Federal Housing Administration, 28, 32, 33

Federal Land Banks, 33

Federal National Mortgage Association, 28, 32, 33

Federal Reserve Banks

Condition statement, 10
Discount rates (See Interest rates)

U.S. government securities held, 5, 10, 11, 25

Federal Reserve credit, 5, 6, 10, 12

Federal Reserve notes, 10

Federally sponsored credit agencies, 28

Finance companies

Assets and liabilities, 30

Business credit, 31

Loans, 34

Paper, 22, 23

Float, 5

Flow of funds, 35-39

Foreign currency operations, 10

Foreign deposits in U.S. banks, 5

Foreign exchange rates, 56

Foreign-related institutions, 20

Foreigners

Claims on, 45, 48-49, 52-53

Liabilities to, $45-47,50-51,54,55$

GOLD

Certificate account, 10

Stock, 5,45

Government National Mortgage Association, 28, 32, 33

INDUSTRIAL production, 42,43

Insurance companies, 25, 33

Interest rates

Bonds, 23

Consumer credit, 34

Federal Reserve Banks, 7

Money and capital markets, 23

Mortgages, 32

Prime rate, 22

International capital transactions of United States, 44-55

International organizations, $45,46-47,48,50-55$

Investment companies, issues and assets, 30

Investments

Commercial banks, 4, 15-21

Federal Reserve Banks, 10, 11

Financial institutions, 33

LIFE insurance companies (See Insurance companies)

Loans

Commercial banks, 15-21, 58-59

Federal Reserve Banks, 5-7, 10, 11

Financial institutions, 33

Insured or guaranteed by United States, 32, 33

\section{MANUFACTURING}

Capacity utilization, 40, 41

Production, 42, 43

Margin requirements, 24

Member banks, reserve requirements, 8

Mining production, 43

Monetary and credit aggregates, 4, 12

Money and capital market rates, 23

Money stock measures and components, 4, 13

Mortgages (See Real estate loans)

Mutual funds, 13, 30

Mutual savings banks (See Thrift institutions) 


\section{PRICES}

Stock market, 24

Prime rate, 22

Production, 42, 43

REAL estate loans

Banks, 15-21, 33

Terms, yields, and activity, 32

Type and holder and property mortgaged, 33

Reserve requirements, 8

Reserves

Commercial banks, 15-21

Depository institutions, 4-6

Federal Reserve Banks, 10

U.S. reserve assets, 45

Residential mortgage loans, 32, 33

Retail credit, 34

\section{SAVING}

Flow of funds, 33, 34, 35-39

Savings deposits (See Time and savings deposits)

Savings institutions, 33, 34, 35-39

Securities (See also U.S. government securities)

Federal and federally sponsored credit agencies, 28

Foreign transactions, 54

New issues, 29

Prices, 24

Special drawing rights, $5,10,44$

State and local governments

Holdings of U.S. government securities, 25

New security issues, 29

Rates on securities, 23
Stock market, selected statistics, 24

Stocks (See also Securities)

New issues, 29

Prices, 24

Student Loan Marketing Association, 28

THRIFT institutions, 4 (See also Credit unions and Savings institutions)

Time and savings deposits, 4, 13, 15-21, 58-59

Treasury cash, Treasury currency, 5

Treasury deposits, 5, 10

\section{U.S. GOVERNMENT balances}

Commercial bank holdings, 15-21

Treasury deposits at Reserve Banks, 5, 10

U.S. government securities

Bank holdings, 15-21, 25

Dealer transactions, positions, and financing, 27

Federal Reserve Bank holdings, 5, 10, 11, 25

Foreign and international holdings and transactions, 10, 25, 55

Open market transactions, 9

Outstanding, by type and holder, 25, 26

Rates, 23

U.S. international transactions, 44-55

Utilities, production, 43

VETERANS Affairs, Department of, 32, 33

WEEKLY reporting by banks, 17,18

YIELDS (See Interest rates) 


\section{Federal Reserve Board Publications}

For ordering assistance, write PUBLICATIONS FULFILLMENT, MS-127, Board of Governors of the Federal Reserve System, Washington, DC 20551, or telephone (202) 452-3245, or FAX (202) 728-5886. You may also use the publications order form available on the Board's website (www.federalreserve.gov). When a charge is indicated, payment should accompany request and be made payable to the Board of Governors of the Federal Reserve System or may be ordered via MasterCard, VISA, or American Express. Payment from foreign residents should be drawn on a U.S. bank.

\section{BOOKS AND MISCELLANEOUS PUBLICATIONS}

annual Percentage Rate Tables (Truth in LendingRegulation Z) Vol. I (Regular Transactions). 1969. 100 pp. Vol. II (Irregular Transactions). 1969. 116 pp. Each volume $\$ 5.00$.

ANNUAL REPORT, 2003.

ANNUAL Report: Budget Review, 2004.

Annual Statistical Digest: period covered, release date, number of pages, and price.

$\begin{array}{llll}1981 & \text { October } 1982 & 239 \mathrm{pp} . & \$ 6.50 \\ 1982 & \text { December } 1983 & 266 \mathrm{pp} . & \$ 7.50 \\ 1983 & \text { October } 1984 & 264 \mathrm{pp} . & \$ 11.50 \\ 1984 & \text { October } 1985 & 254 \mathrm{pp} . & \$ 12.50 \\ 1985 & \text { October } 1986 & 231 \mathrm{pp} . & \$ 15.00 \\ 1986 & \text { November } 1987 & 288 \mathrm{pp} . & \$ 15.00 \\ 1987 & \text { October } 1988 & 272 \mathrm{pp} . & \$ 15.00 \\ 1988 & \text { November } 1989 & 256 \mathrm{pp} . & \$ 25.00 \\ 1980-89 & \text { March } 1991 & 712 \mathrm{pp} . & \$ 25.00 \\ 1990 & \text { November } 1991 & 185 \mathrm{pp} . & \$ 25.00 \\ 1991 & \text { November } 1992 & 215 \mathrm{pp} . & \$ 25.00 \\ 1992 & \text { December } 1993 & 215 \mathrm{pp} . & \$ 25.00 \\ 1993 & \text { December } 1994 & 281 \mathrm{pp} . & \$ 25.00 \\ 1994 & \text { December } 1995 & 190 \mathrm{pp} . & \$ 25.00 \\ 1990-95 & \text { November } 1996 & 404 \mathrm{pp} . & \$ 25.00 \\ 1996-2000 & \text { March } 2002 & 352 \mathrm{pp} . & \$ 25.00\end{array}$

Federal Reserve Bulletin. Quarterly. $\$ 10.00$ per year or $\$ 2.50$ each in the United States, its possessions, Canada, and Mexico. Elsewhere, $\$ 15.00$ per year or $\$ 3.50$ each.

Federal Reserve Regulatory Service. Loose-leaf; updated monthly. (Requests must be prepaid.)

Consumer and Community Affairs Handbook. $\$ 75.00$ per year.

Monetary Policy and Reserve Requirements Handbook. $\$ 75.00$ per year.

Securities Credit Transactions Handbook. $\$ 75.00$ per year.

The Payment System Handbook. $\$ 75.00$ per year.

Federal Reserve Regulatory Service. Four vols. (Contains all four Handbooks plus substantial additional material.) $\$ 200.00$ per year.

Rates for subscribers outside the United States are as follows and include additional airmail costs:

Federal Reserve Regulatory Service, $\$ 250.00$ per year.

Each Handbook, $\$ 90.00$ per year
Federal Reserve Regulatory Service for Personal COMPUTERS. CD-ROM; updated monthly.

Standalone PC. $\$ 300$ per year.

Network, maximum 1 concurrent user. $\$ 300$ per year.

Network, maximum 10 concurrent users. $\$ 750$ per year.

Network, maximum 50 concurrent users. $\$ 2,000$ per year.

Network, maximum 100 concurrent users. $\$ 3,000$ per year

Subscribers outside the United States should add $\$ 50$ to cover additional airmail costs.

The Federal Reserve System-Purposes and Functions. $2005.136 \mathrm{pp}$.

Guide to THE Flow OF Funds Accounts. January 2000. 1,186 pp. $\$ 20.00$ each.

Regulations of the BoARd of Governors of the Federal RESERVE SYSTEM.

Statistical Supplement to the Federal Reserve Bulletin. Monthly. \$25.00 per year or \$2.50 each in the United States, its possessions, Canada, and Mexico. Elsewhere, $\$ 35.00$ per year or $\$ 3.50$ each.

\section{EDUCATION PAMPHLETS}

Short pamphlets suitable for classroom use. Multiple copies are available without charge.

A Consumer's Guide to Mortgage Lock-Ins

A Consumer's Guide to Mortgage Settlement Costs

A Consumer's Guide to Mortgage Refinancings

A Guide to Business Credit for Women, Minorities, and Small Businesses

Choosing a Credit Card

Consumer Handbook on Adjustable Rate Mortgages (also available in Spanish)

Consumer Handbook to Credit Protection Laws

Home Mortgages: Understanding the Process and Your Right to Fair Lending

How to File a Consumer Complaint about a Bank (also available in Spanish)

In Plain English: Making Sense of the Federal Reserve

Keys to Vehicle Leasing (also available in Spanish)

Looking for the Best Mortgage (also available in Spanish)

Making Sense of Savings

Privacy Choices for Your Personal Financial Information

Protecting Yourself from Overdraft and Bounced-Check Fees

Putting Your Home on the Loan Line Is Risky Business (also available in Spanish)

Series on the Structure of the Federal Reserve System

The Board of Governors of the Federal Reserve System

The Federal Open Market Committee

Federal Reserve Bank Board of Directors

Federal Reserve Banks

What You Should Know About Home Equity Lines of Credit (also available in Spanish)

When Is Your Check Not a Check? (also available in Spanish) 


\section{STAFF STUDIES: Only Summaries Printed in the BULLETIN}

Studies and papers on economic and financial subjects that are of general interest. Staff Studies 1-158, 161, 163, 165, 166, 168, and 169 are out of print, but photocopies of them are available. Staff Studies 165-176 are available online at www.federalreserve.gov/ pubs/staffstudies. Requests to obtain single copies of any paper or to be added to the mailing list for the series may be sent to Publications Fulfillment.

159. New Data on the Performance of Nonbank SubsidiarIES OF BANK Holding Companies, by Nellie Liang and Donald Savage. February 1990. 12 pp.

160. Banking Markets and the USE of Financial SeRvices by Small and Medium-Sized Businesses, by Gregory E. Elliehausen and John D. Wolken. September $1990.35 \mathrm{pp}$.

162. Evidence on the Size of Banking Markets from MortGage Loan Rates in Twenty Cities, by Stephen A. Rhoades. February 1992. 11 pp

164. THE 1989-92 CREDit CRUNCH FOR REAL Estate, by James T. Fergus and John L. Goodman, Jr. July 1993. $20 \mathrm{pp}$.

167. A Summary of Merger Performance Studies in BankING, 1980-93, AND AN AsSESSMENT OF THE "OPERATING Performance" and "Event Study" Methodologies, by Stephen A. Rhoades. July 1994. 37 pp.
170. The Cost of Implementing Consumer Financial Regulations: AN ANALysis of EXPERIENCE WITH the TRUTH IN SAVINGS ACT, by Gregory Elliehausen and Barbara R. Lowrey. December 1997. $17 \mathrm{pp}$.

171. The Cost of Bank Regulation: A Review of the EviDENCE, by Gregory Elliehausen. April 1998. 35 pp.

172. Using Subordinated DebT as an Instrument of Market Discipline, by Study Group on Subordinated Notes and Debentures, Federal Reserve System. December 1999. 69 pp.

173. Improving Public Disclosure in Banking, by Study Group on Disclosure, Federal Reserve System. March 2000. $35 \mathrm{pp}$.

174. Bank Mergers and Banking Structure in the United STATES, 1980-98, by Stephen Rhoades. August 2000. 33 pp.

175. The Future of Retall Electronic Payments Systems: INDUSTRY INTERVIEWS AND ANALYSIS, Federal Reserve Staff, for the Payments System Development Committee, Federal Reserve System. December 2002. 27 pp.

176. Bank Merger Activity in the United States, 1994 2003, by Steven J. Pilloff. May 2004. 23 pp. 


\section{ANTICIPATED SCHEDULE OF RELEASE DATES FOR PERIODIC STATISTICAL RELEASES OF THE BOARD OF GOVERNORS OF THE FEDERAL RESERVE SYSTEM}

For ordering assistance, write PUBLICATIONS FULFILLMENT, MS-127, Board of Governors of the Federal Reserve System, 20th Street and Constitution Ave., N.W., Washington, DC 20551, or telephone (202) 452-3244, or FAX (202) 728-5886. You may also use the publications order form available on the Board's website (www.federalreserve.gov). When a charge is indicated, payment should accompany request and be made payable to the Board of Governors of the Federal Reserve System or may be ordered via MasterCard, VISA, or American Express. Payment from foreign residents should be drawn on a U.S. bank.

$\begin{array}{cccc}\text { Annual } & \text { Annual } & \text { Approximate } \\ \text { Release number and title } & \text { mail } & \text { fax } & \text { release } \\ & \text { rate } & \text { rate } & \text { days } 1\end{array}$

Period or date to
which data refer

Corresponding Bulletin or Statistical Supplement table numbers ${ }^{2}$

\section{Weekly Releases}

H.2. Actions of the Board: Applications and Reports Received

H.3. Aggregate Reserves of Depository Institutions and the Monetary Base ${ }^{3}$

H.4.1. Factors Affecting Reserve Balances of Depository Institutions and Condition Statement of Federal Reserve Banks ${ }^{3}$

H.6. Money Stock Measures ${ }^{3}$

$\begin{array}{lll}\$ 55.00 & \text { n.a. } & \text { Friday } \\ \$ 20.00 & \text { n.a. } & \text { Thursday } \\ \$ 20.00 & \text { n.a. } & \text { Thursday } \\ \$ 35.00 & \text { n.a. } & \text { Thursday } \\ \$ 30.00 & \text { n.a. } & \text { Friday } \\ \$ 20.00 & \$ 20.00 & \text { Monday } \\ \$ 20.00 & \$ 20.00 & \text { Monday }\end{array}$

H.15. Selected Interest Rates ${ }^{3}$
Comets and Liabilities of
Commercial Banks in the United States $^{3}$

H.10. Foreign Exchange Rates ${ }^{3}$$$
\$ 20.00 \quad \text { Monday }
$$

\begin{tabular}{|c|c|c|c|c|}
\hline$\$ 5.00$ & $\$ 5.00$ & First of month & Previous month & 3.28 \\
\hline No charge & n.a. & First of month & Previous month & $\ldots$ \\
\hline$\$ 15.00$ & n.a. & Midmonth & Previous month & $2.12,2.13$ \\
\hline$\$ 5.00$ & $\$ 5.00$ & $\begin{array}{l}\text { Fifth working day } \\
\text { of month }\end{array}$ & $\begin{array}{l}\text { Second month } \\
\text { previous }\end{array}$ & $1.55,1.56$ \\
\hline$\$ 5.00$ & n.a. & End of month & $\begin{array}{l}\text { Second month } \\
\text { previous }\end{array}$ & $1.51,1.52$ \\
\hline
\end{tabular}

\section{Monthly Releases}

G.5. Foreign Exchange Rates ${ }^{3}$

G.15. Research LibraryRecent Acquisitions

G.17. Industrial Production and Capacity Utilization ${ }^{3}$

G. 19. Consumer Credit ${ }^{3}$

G.20. Finance Companies ${ }^{3}$

Week ending
previous
Saturday
Week ending
previous
Wednesday
Week ending
previous
Wednesday

Week ending
Monday of
previous week
Week ending
previous
Wednesday
Week ending
previous
Friday
Week ending
previous
Friday

$1.11,1.18$

$1.26 \mathrm{~A}-\mathrm{F}$

3.28 


\begin{tabular}{|c|c|c|c|c|c|}
\hline Release number and title & $\begin{array}{l}\text { Annual } \\
\text { mail } \\
\text { rate }\end{array}$ & $\begin{array}{l}\text { Annual } \\
\text { fax } \\
\text { rate }\end{array}$ & $\begin{array}{c}\text { Approximate } \\
\text { release } \\
\text { days }^{1}\end{array}$ & $\begin{array}{l}\text { Period or date to } \\
\text { which data refer }\end{array}$ & $\begin{array}{l}\text { Bulletin or } \\
\text { Statistical } \\
\text { Supplement } \\
\text { table numbers }\end{array}$ \\
\hline
\end{tabular}

\section{Quarterly Releases}

E.2. Survey of Terms of Business Lending ${ }^{3}$

E.11. Geographical Distribution of Assets and Liabilities of

Major Foreign Branches of

U.S. Banks

E.16. Country Exposure Lending Survey ${ }^{3}$

Z.1. Flow of Funds Accounts

of the United States:

Flows and Outstandings ${ }^{3}$
$\$ 5.00$

n.a.
Midmonth of
March, June,
September, and

\section{February, May, \\ August, and \\ November}

December

$\$ 5.00 \quad$ n.a.

15th of March,

June,

September, and

December

$\$ 5.00 \quad$ n.a

January, April,

July, and

October

n.a.

Second week of

March, June,

September, and

December

Previous quarter

. .

.




\section{Publications of Interest}

\section{FEDERAL RESERVE REGULATORY SERVICE}

To promote public understanding of its regulatory functions, the Board publishes the Federal Reserve Regulatory Service, a four-volume loose-leaf service containing all Board regulations as well as related statutes, interpretations, policy statements, rulings, and staff opinions. For those with a more specialized interest in the Board's regulations, parts of this service are published separately as handbooks pertaining to monetary policy, securities credit, consumer affairs, and the payment system.

These publications are designed to help those who must frequently refer to the Board's regulatory materials. They are updated monthly, and each contains citation indexes and a subject index.

The Monetary Policy and Reserve Requirements Handbook contains Regulations A, D, and Q, plus related materials.

The Securities Credit Transactions Handbook contains Regulations T, U, and X, which deal with extensions of credit for the purchase of securities, and related statutes, Board interpretations, rulings, and staff opinions. Also included is the Board's list of foreign margin stocks.

The Consumer and Community Affairs Handbook contains Regulations B, C, E, G, M, P, Z, AA, BB, and $\mathrm{DD}$, and associated materials.
The Payment System Handbook deals with expedited funds availability, check collection, wire transfers, and risk-reduction policy. It includes Regulations CC, J, and $\mathrm{EE}$, related statutes and commentaries, and policy statements on risk reduction in the payment system.

For domestic subscribers, the annual rate is $\$ 200$ for the Federal Reserve Regulatory Service and $\$ 75$ for each handbook. For subscribers outside the United States, the price, which includes additional airmail costs, is $\$ 250$ for the service and $\$ 90$ for each handbook.

The Federal Reserve Regulatory Service is also available on CD-ROM for use on personal computers. For a standalone PC, the annual subscription fee is $\$ 300$. For network subscriptions, the annual fee is $\$ 300$ for 1 concurrent user, $\$ 750$ for a maximum of 10 concurrent users, $\$ 2,000$ for a maximum of 50 concurrent users, and $\$ 3,000$ for a maximum of 100 concurrent users. Subscribers outside the United States should add $\$ 50$ to cover additional airmail costs. For further information, call (202) 452-3244.

All subscription requests must be accompanied by a check or money order payable to the Board of Governors of the Federal Reserve System. Orders should be addressed to Publications Fulfillment, Mail Stop 127, Board of Governors of the Federal Reserve System, Washington, DC 20551.

\section{GUIDE TO THE FLOW OF FUNDS ACCOUNTS}

A new edition of Guide to the Flow of Funds Accounts is now available from the Board of Governors. The new edition incorporates changes to the accounts since the initial edition was published in 1993. Like the earlier publication, it explains the principles underlying the flow of funds accounts and describes how the accounts are constructed. It lists each flow series in the Board's flow of funds publication, "Flow of Funds Accounts of the United States" (the Z.1 quarterly statistical release), and describes how the series is derived from source data. The Guide also explains the relationship between the flow of funds accounts and the national income and product accounts and discusses the analytical uses of flow of funds data. The publication can be purchased, for $\$ 20.00$, from Publications Fulfillment, Mail Stop 127, Board of Governors of the Federal Reserve System, Washington, DC 20551. 


\section{Federal Reserve Statistical Releases Available on the Commerce Department's Economic Bulletin Board}

The Board of Governors of the Federal Reserve System makes some of its statistical releases available to the public through the U.S. Department of Commerce's economic bulletin board. Computer access to the releases can be obtained by subscription.
For further information regarding a subscription to the economic bulletin board, please call (202) 4821986. The releases transmitted to the economic bulletin board, on a regular basis, are the following:

Reference

Number

Statistical release

Frequency of release

H.3

Aggregate Reserves

Weekly/Thursday

H.4.1

Factors Affecting Reserve Balances

Weekly/Thursday

H.6

Money Stock

Weekly/Thursday

H.8

Assets and Liabilities of Insured Domestically Chartered and Foreign Related Banking Institutions

Weekly/Monday

H.10

Foreign Exchange Rates

Weekly/Monday

H.15

Selected Interest Rates

Weekly/Monday

G.5

Foreign Exchange Rates

Monthly/end of month

G.17

Industrial Production and Capacity Utilization

Monthly/midmonth

G.19

Consumer Installment Credit

Monthly/fifth business day

Z.1

Flow of Funds

Quarterly 